\title{
Ace2 y la regulación de la separación celular en Candida albicans
}

Diana Milena Calderón Noreña

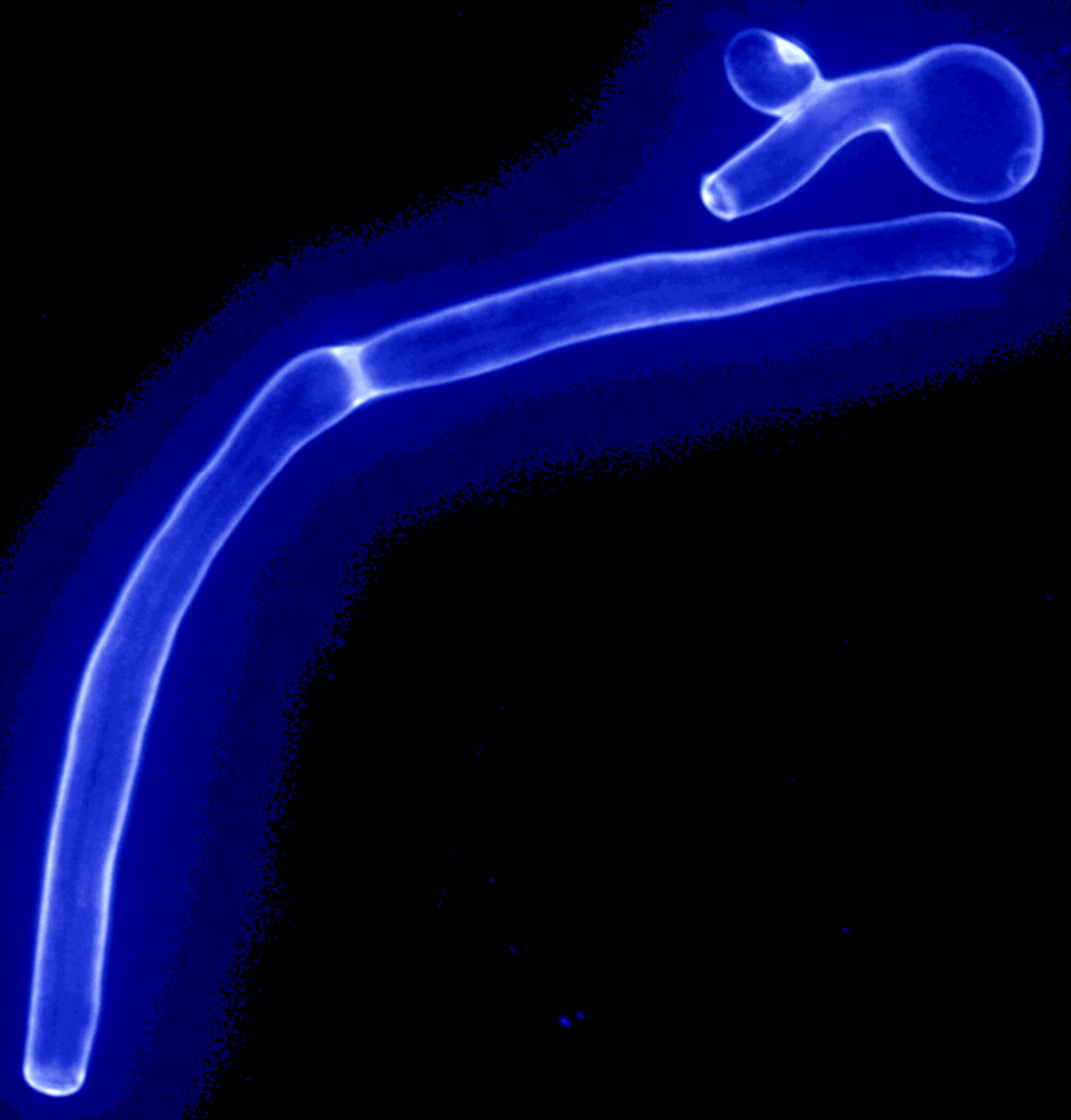

Salamanca, 2013 



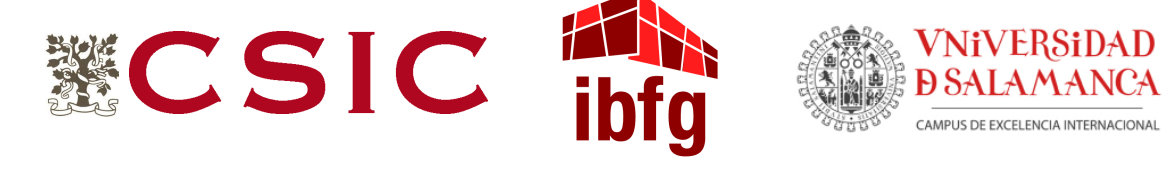

\section{UNIVERSIDAD DE SALAMANCA \\ INSTITUTO DE BIOLOGÍA FUNCIONAL Y GENÓMICA}

\section{ACE2 y la regulación de la separación celular en Candida albicans}

Diana Milena Calderón Noreña 

EL Dr. LUIS ROMÁN FERNÁNDEZ LAGO, PROFESOR TITULAR Y DIRECTOR DEL DEPARTAMENTO DE MICROBIOLOGÍA Y GENÉTICA DE LA UNIVERSIDAD DE SALAMANCA

\section{CERTIFICA:}

Que la memoria titulada "Ace2 y la regulación de la separación celular en Candida albicans", presentada por la licenciada Diana Milena Calderón Noreña para optar al grado de Doctor en Biología, ha sido realizada bajo la dirección de los Dres. Carlos Rodríguez Vázquez de Aldana y Francisco del Rey Iglesias, en el Instituto de Biología Funcional y Genómica, Centro Mixto de la Universidad de Salamanca (Departamento de Microbiología y Genética) y el Consejo Superior de Investigaciones Científicas.

Y para autorizar su presentación y evaluación por el tribunal correspondiente, firma el presente certificado en Salamanca, a de de 2013

Fdo. Dr. Luis Román Fernández Lago 

EI Dr. CARLOS RODRÍGUEZ VÁZQUEZ DE ALDANA, INVESTIGADOR CIENTÍFICO DEL CSIC Y EL Dr. FRANCISCO J. DEL REY IGLESIAS, CATEDRÁTICO DE MICROBIOLOGÍA DE LA UNIVERSIDAD DE SALAMANCA

\section{CERTIFICAN:}

Que la licenciada Diana Milena Calderon Noreña ha realizado el trabajo titulado "Ace2 y la regulación de la separación celular en Candida albicans" bajo su dirección, en el Centro Mixto Instituto de Biología Funcional y Genómica (CSIC)/ Departamento de Microbiología y Genética (USAL).

Y para autorizar su presentación y evaluación por el tribunal correspondiente, firmamos el presente certificado en Salamanca a de de 2013.

Dr. Carlos Rodríguez Vázquez de Aldana Dr. Francisco J. Del Rey Iglesias 

Hace ya cuatro años que emprendí mi viaje, ha sido un camino largo lleno de aventuras y experiencias, y aunque aún no he llegado a Ítaca, han sido muchas las mañanas de verano en las que he arribado -icon placery alegría!-a puertos nunca vistos antes...

Estos agradecimientos no pueden empezar por otras personas diferentes a Carlos y Paco. No sé cómo expresar la infinita gratitud que siento por la oportunidad y confianza que me han brindado. Carlos: las collejas no han sido en vano, creo que no he vuelto a confundir transcripción con traducción (un problema semántico, más que conceptual...); valiosas todas y cada una de las enseñanzas que me has dado. Quiero decirte que seguiré mi camino a ĺtaca dudando de si algún día encontraré un jefe mejor que tú. Paco: como manera de agradecimiento, quiero dejar por escrito en esta memoria que si algún día llego a "cortar el bacalao" organizaré un congreso en Cartagena de Indias (Colombia) para el cual tú y todo el laboratorio p1.5 serán los invitados de honor. jhe dicho!.

A Belén, por toda su infinita ayuda, por su paciencia, por su amistad y por todo lo que de ella he aprendido. Belén: Sabes que sin ti no habría habido un final feliz.

A Jimmy, Alberto y Pilar por la ayuda con experimentos y sobre todo con las ideas, este trabajo es tan mío como de ustedes.

A todo el personal del IBFG que me ha apoyado y ayudado durante este tiempo, en especial a Alegría y Paco Soriano por aguantar toda la guerra que les di con los trámites administrativos, a Paco Antequera por los consejos para la escritura de la tesis y a Olga Calvo por el préstamo de anticuerpos y otros insumos de laboratorio.

A Jamie Konopka y todo el labo de Stony Brook, por mostrarme el "fascinante mundo" de las membranas, campo en el que llevaré a cabo mi post-doctorado.

A Yolanda y Encarna, pues como ya alguien dijo por ahí: "6 manos hacen más que dos".

A la gente del labo p1.5, Don Javiercito y Sarita, por toda su ayuda con la gramática (iy mira que hablamos el mismo idioma!) y por el excelente ambiente de trabajo a su lado.

A mis amigos Alicia, Esther, Alejito, Camilla, David, Charlie, Raúl, Pedro, Sergio, Miguel, Susana, Rebeca, Sandrine, Sandra, Ximena, Pipe, Nidia, Vane y Hugo (jespero que no se me quede ningún nombre!), por convertir este difícil camino en toda una fiesta.

A Tatiana, Diana y Jenny, compañeras de camino hacia un sueño común que hoy es toda una realidad. Chicas, sin ustedes nada de esto habría sido igual.

A Andrés. Es muy probable que hoy no seamos los mismos que hace 5 años, pero si algo es cierto es que has estado en todos mis triunfos y caídas para celebrar conmigo o para ayudarme a levantar.

A Fran por su paciencia, cariño, comprensión y por su apoyo incondicional en una de las etapas más difíciles de mi vida. Sin él y sus mil y una forma de hacerme sonreír en los peores momentos, no habría terminado jamás de escribir esta tesis.

Por último y no menos importante, a toda mi familia, por comprender mi partida, por ser el pilar más importante de toda mi existencia, por hacer de mí lo que hoy soy. Mamá, Papá, Omar, Javi, y 
Samy (próximamente Etel): no olviden nunca que la brújula que dirige mi embarcación siempre apunta a las tierras en las que ustedes están...

Quiero agradecer de ante mano a cualquier persona que lea esta memoria, por comprender que la belleza del Castellano radica en las múltiples divergencias que éste ha tenido a lo largo de su evolución. Así, si usted se encuentra con palabras que no forman parte de su vocabulario habitual, tenga en cuenta que en algún otro país de los 22 en los que se habla la lengua castellana, podría ser una palabra de amplio uso.

PARAFRASEANDO A UNO DE MIS CANTATES FAVORITOS (GUSTAVO CERATTI):

\section{iiiGRACIAS TOTALES!!!}


"Happy is he who gets to know the reasons for things." "Feliz es aquel que llega a conocer el porqué de las cosas."

Virgil. 

$\Delta=$ Disrupción

IPPA = Fosfatasa

5'UTR = "5'Untranslated región"

aa = Aminoácido

ATP = Adenosin tri-fosfato

CAMP = Adenosin mono-fosfato cíclico

Cdc = Ciclo de división celular ("Cell Division Cycle")

CDK = Kinasa Depeniente de Ciclina ("Cyclin-Dependent Kinase")

cDNA = DNA copia

$\mathrm{CF}=$ Calcofluor

C-terminal $=$ Carboxiterminal

DAPI = 4',6-diamidino-2-phenylindole

DEPC = Dietilpirocarbonato

DIC = "Differential Interference Contrast"

DMSO = Dimetilsulfóxido

DNA = Ácido desoxirribonucleotido

dNTPs = Desoxinucleotidos trifosfato

DO = Densidad óptica

DTT = Ditiotreitol

EDTA = Ácido etilendiaminotetraacético

FRAP = "Fluorescence Recovery After Photobleaching"

GAP = "GTPase Activating Protein"

GCK = Quinasas del centro germinal

GlcNAc $=$ N-acetil-D-glucosamina

GEF = "Guanine nucleotide Exchange Factor"

GFP = Proteína Fluorescente Verde

GTP = Guanosín trifosfato

GTPasa = Guanosina trifosfatasa

HEPES = (4-(2-hydroxyethyl)-1-piperazineethanesulfonic acid)

$\mathrm{HM}=$ Motivo hidrofóbico

HSS = "Hyphae-Specific State"

HSG $=$ Genes específicos de hifas

Kda $=$ Kilodaltons

$\mathbf{k V}=$ kilovoltios

LB = "Luria Broth"

LiAc = "litium Acetate"

MEN = "Mitotic Exit Network"

MET = Metionina

mRNA = RNA mensajero

MOR = "Morphogenesis related NDR kinase network"

MTTFs = "Membrane-Tethered Transcription Factors"

$\mathbf{N}$-terminal $=$ Aminoterminal

NDR = "Nuclear Dbf2-related family"

NES = Señal de exportación nuclear

NLS = Señal de importación nuclear

NORS = "Non-Regulated Secundary Structure"

ORF = Fase de lectura abierta

$\mathbf{P b}=$ Pares de bases 
PBS = Tampón fosfato salino

PBS- T = Buffer fosfato salino más Tween al 1\%

PCR = Reacción en cadena de la polimerasa

PEG = Polietilen Glicol

PIP = Fosfoinositoles fosforilados

PKA = Protein kinasa $\mathrm{A}$

PMSF = "Phenylmethylsulfonyl fluoride"

PVDF = "Polyvinylidene fluoride"

qRT-PCR = PCR cuantitativa

RACE = "Rapid Amplification of cDNA Ends"

RIP = "Regulated Intramembrane Proteolisis"

RAM = "Regulation of Ace2 and Morphogenesis"

RNA = Ácido Ribonucleico

RNAasa $=$ Ribonucleasa

r.p.m = Revoluciones por minuto

RUP = "Regulated Ubiquitin/proteasome-dependent Processing"

SDS = Dodecil Sulfato Sódico

SUE = "Septine Unique Element"

SUMO = "Small Ubiquitin-Related Modifier"

TCA = Ácido tricloroacético

TM = Transmembrana

uORF = "Upstream Open Reading Frames"

UPR = "Unfolded Protein Response"

UV = Ultravioleta

YEPD = "Yeast Extract Peptone Dextrose"

YNB = "Yeast Nitrogen Base"

VIH = Virus de la inmunodeficiencia humana 
Indice

AGRADECIMIENTOS

v

ABREVIATURAS Y SIGLAS .

ix

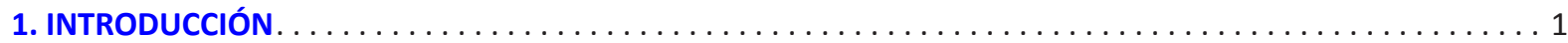

1.1 LEVADURAS: LOS ORGANISMOS MODELO POR EXCELENCIA $\ldots \ldots \ldots \ldots \ldots \ldots \ldots \ldots \ldots \ldots$

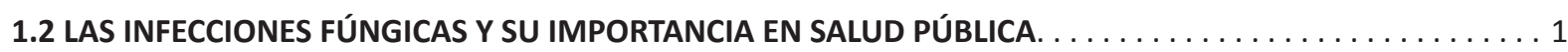

1.3 Candida albicans: EL HONGO PATÓGENO MÁS COMÚNMENTE AISLADO $\ldots \ldots \ldots \ldots \ldots \ldots \ldots$

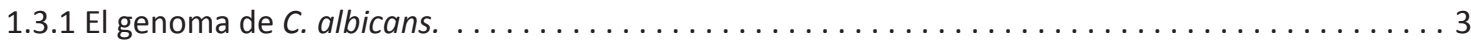

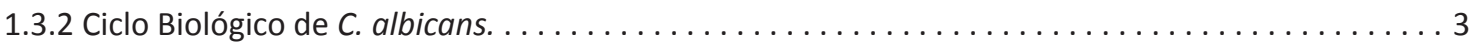

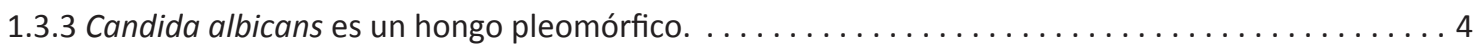

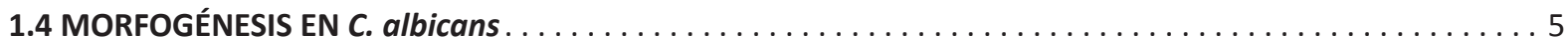

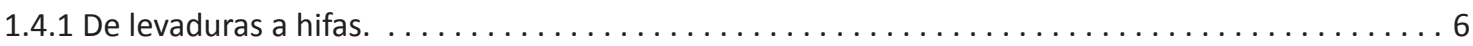

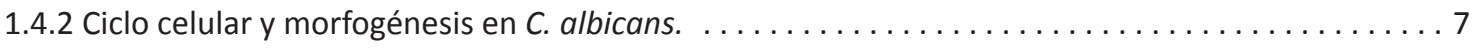

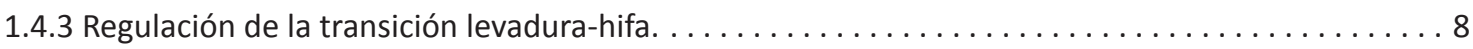

1.4.4 Dianas esenciales de las vías de transducción de señales en la morfogénesis de hifas. . . . . . . 8

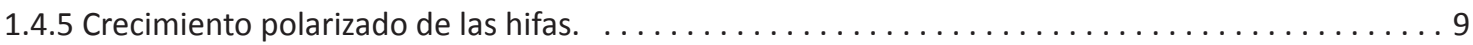

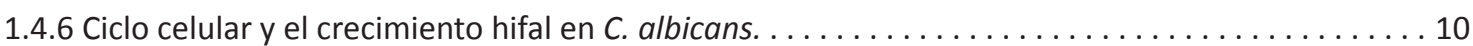

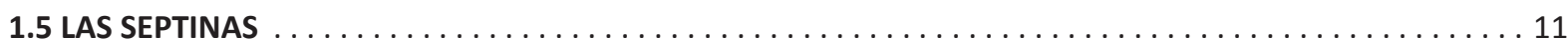

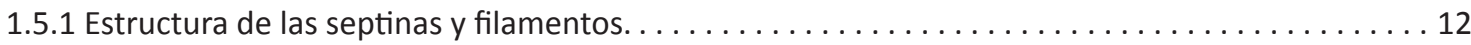

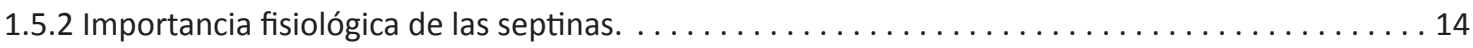

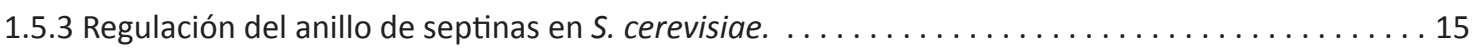

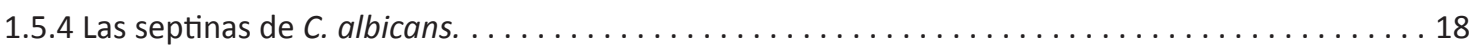

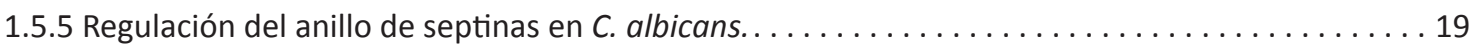

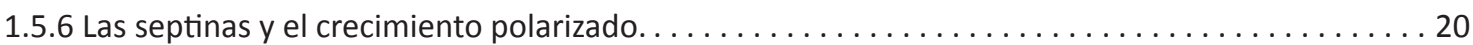

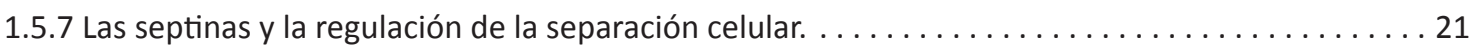

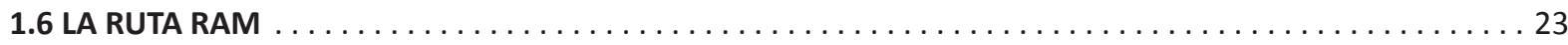

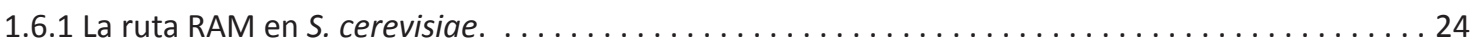

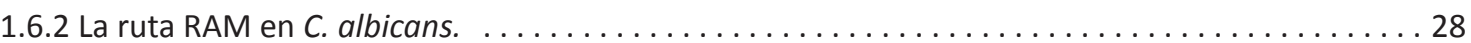

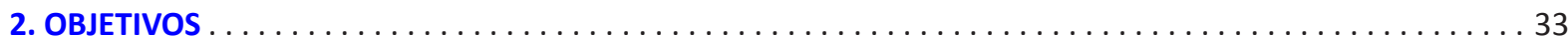

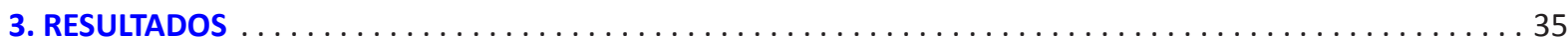

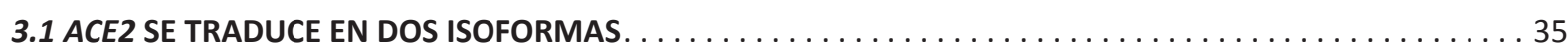

3.1.1 Ace2 participa en la regulación de la dinámica del anillo de septinas durante el crecimiento

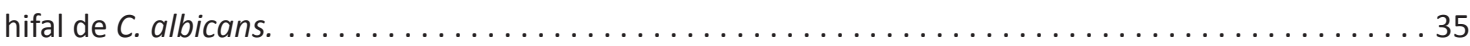

3.1.2 La regulación de la dinámica del anillo de septinas es independiente de la actividad transcrip-

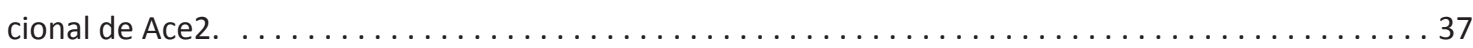

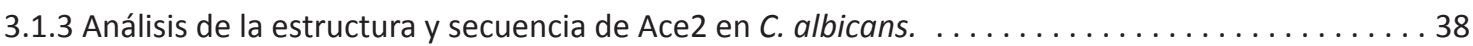

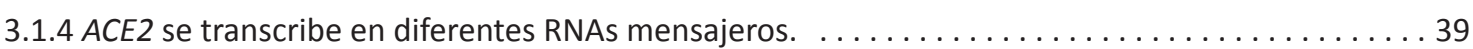

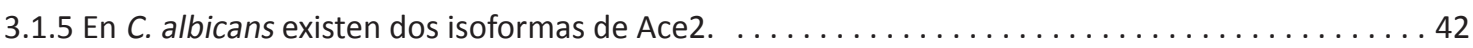

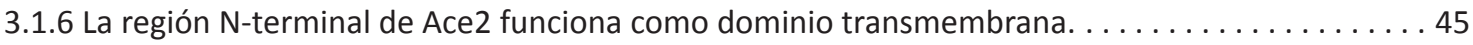

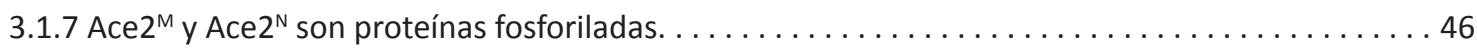

3.1.8 Las dos formas de Ace2 fraccionan en diferentes compartimentos subcelulares. . . . . . . . 46

3.1.9 En C. albicans Ace2 se localiza en el núcleo y en puntos citoplásmicos. . . . . . . . . . 49

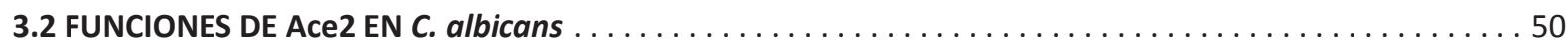

3.2.1 Funciones de $A c e 2^{\mathrm{N}}$ y $A c e 2^{\mathrm{M}}$ durante el crecimiento en forma de levaduras. . . . . . . . . 52

3.2.2 Funciones de $A c e 2^{\mathrm{N}}$ y $A c e 2^{\mathrm{M}}$ durante el crecimiento en forma de hifas. . . . . . . . . . 52 
3.2.3 Ace $2^{\mathrm{M}}$ es necesario para el correcto posicionamiento del primer septo en los filamentos de

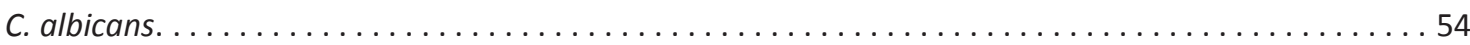

3.2.4 Ace $2^{\mathrm{M}}$ se necesita para el correcto ensamblaje del anillo de septinas en las hifas de C. albicans. . 54

3.2.5 Ace $2^{\mathrm{M}}$ es necesaria para convertir los anillos de septinas al estado específico de hifas. . . . . . 55

3.2.6 Ace $2^{\mathrm{M}}$ es esencial para inhibir la separación de los compartimentos celulares de las hifas. . . . . 56

3.2.7 La inserción ectópica de $\mathrm{Ace} 2^{\mathrm{M}}$ revierte el fenotipo de separación celular. . . . . . . . . . . 57

3.2.8 Análisis de las regiones necesarias para la función de $A c e 2^{\mathrm{M}}$ durante el crecimiento hifal de

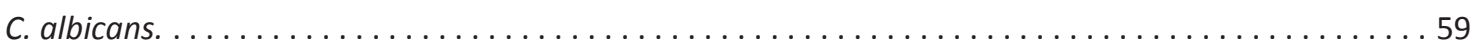

3.2 .9 Ace $^{\mathrm{M}}$ y $A c e 2^{\mathrm{N}}$ interaccionan con el complejo Cbk1-Mob2. . . . . . . . . . . . . . . 61

3.2.10 Ace2 no es necesaria para la correcta localización de Gin4 en el septo. . . . . . . . . . . 62

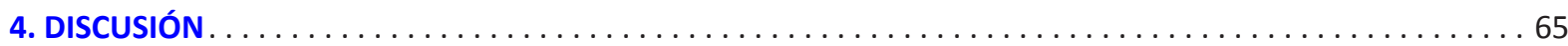

4.1 EL LOCUS ACE2 DE $C$. albicans PRESENTA UNA COMPLEJA ESTRUCTURA . . . . . . . . . . . 65

4.2 C. albicans POSEE DOS FORMAS DE LA PROTEÍNA Ace 2 CON PROPIEDADES DISTINTAS. . . . . . . . 68

4.3 FUNCIONES DE LAS DOS FORMAS DE Ace2 EN LOS DISTINTOS ESTADOS MORFOGÉNETICOS. . . . . . . 70

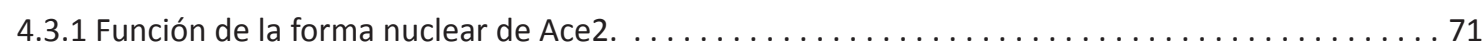

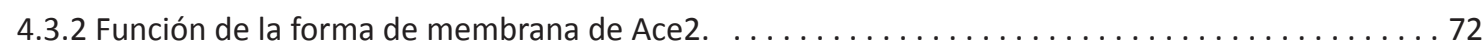

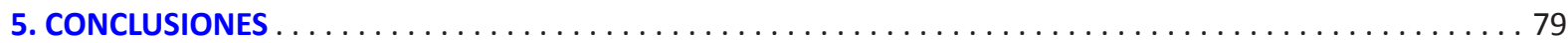

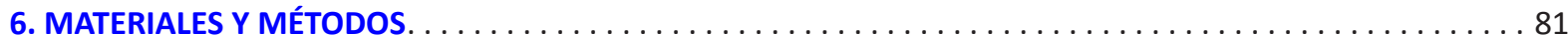

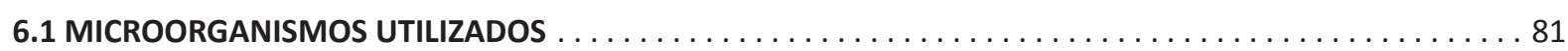

6.2 MEDIOS DE CULTIVO Y CONDICIONES DE CRECIMIENTO $\ldots \ldots \ldots \ldots \ldots \ldots \ldots \ldots \ldots \ldots \ldots \ldots \ldots$

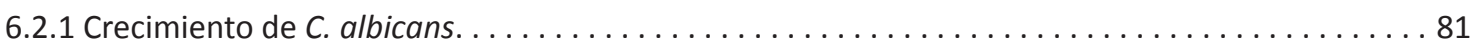

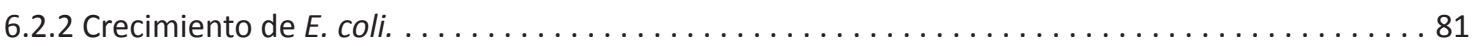

6.3 PROCEDIMIENTOS GENERALES DE CLONACIÓN MOLECULAR $\ldots \ldots \ldots \ldots \ldots \ldots \ldots \ldots \ldots \ldots \ldots$

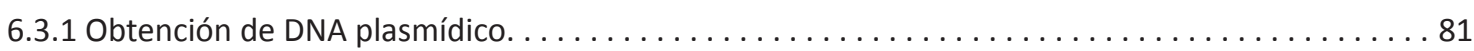

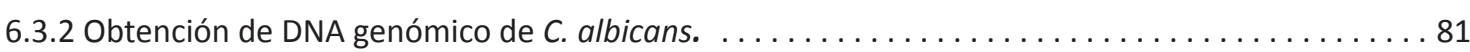

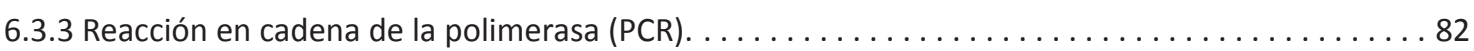

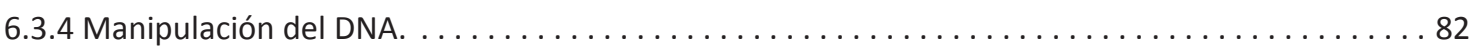

6.3.5 Detección de los sitios de inicio de transcripción (RACE) $\ldots \ldots \ldots \ldots \ldots \ldots \ldots \ldots \ldots \ldots \ldots 2$

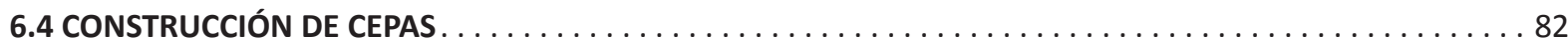

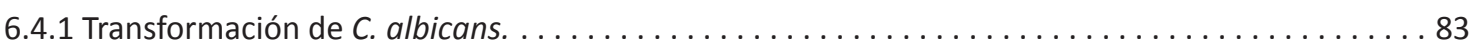

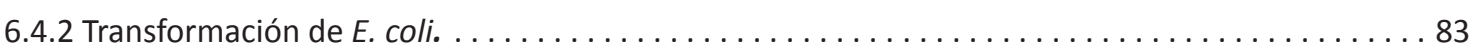

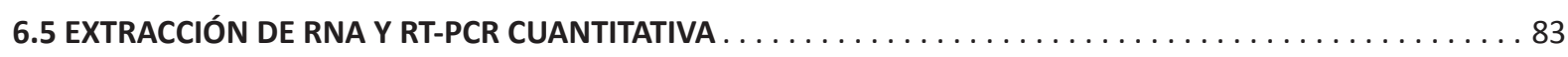

6.6 EXTRACCIÓN, DETECCIÓN Y ANÁLISIS DE PROTEÍNAS $\ldots \ldots \ldots \ldots \ldots \ldots \ldots \ldots \ldots \ldots \ldots \ldots \ldots$

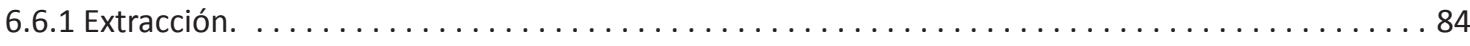

6.6.2 Separación electroforética e inmunodetección de proteínas (Western-blot). . . . . . . . . . 844

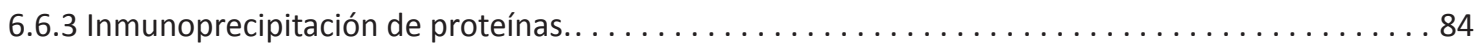

6.6.4 Fraccionamiento celular en gradientes de sacarosa. $\ldots \ldots \ldots \ldots \ldots \ldots \ldots \ldots \ldots \ldots \ldots \ldots \ldots$

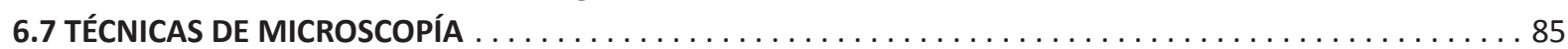

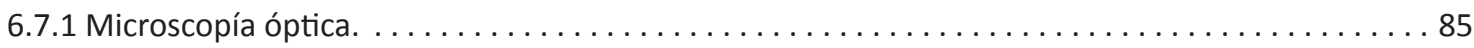

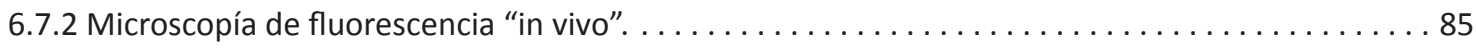

6.7.3 Microscopía confocal: Recuperación de fluorescencia después de "photobleaching" (FRAP). . . 85

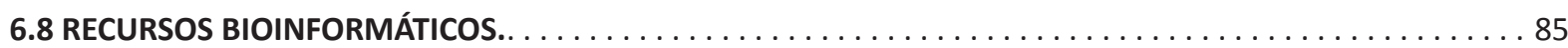

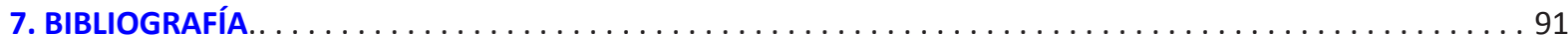


1.Introducción 



\subsection{LEVADURAS: LOS ORGANISMOS MODELO POR EXCELENCIA}

Con sólo una decima parte del tamaño de un leucocito, las levaduras presentan muchas de las funciones celulares de los organismos superiores; así, aproximadamente 200 genes involucrados en enfermedades humanas presentan homólogos en el genoma de estos microorganismos (Phillips et al., 2006). Tan importante y amplio ha sido su estudio como modelo, que en la actualidad la mayor parte del conocimiento que se tiene del ciclo celular y su control ha sido gracias a las levaduras antes que a cualquier otro organismo modelo.

Probablemente la contribución más importante de las levaduras modelo (Saccharomyces cerevisiae y Schizosaccharomyces pombe) y de la comunidad científica que estudia la biología de estos organismos, ha sido la de describir las conexiones de genes y proteínas con las funciones que éstas últimas cumplen en la célula. Además, los métodos para introducir mutaciones dirigidas por el investigador en el genoma de las levaduras han hecho particularmente fácil el estudio no solamente de las funciones bioquímicas, sino también las consecuencias biológicas de la falta de la función de un gen (Botstein y Fink, 2011).

Durante los últimos años, el hongo patógeno Candida albicans ha surgido como un modelo de estudio muy interesante. Al igual que otros hongos patógenos, comparte muchos de sus procesos biológicos con los seres humanos, lo que implica que la mayor parte de las drogas antifúngicas pueden también causar efectos colaterales a quien las consume. Este hecho conlleva que las dosis a las que pueden ser usados los antifúngicos, tengan efectos fungistáticos más que fungicidas. Por tanto, un objetivo importante de las investigaciones con modelos como $C$. albicans reside en el hecho de identificar dianas apropiadas para las terapias antifúngicas (Berman y Sudbery, 2002).

\subsection{LAS INFECCIONES FÚNGICAS Y SU IMPORTANCIA EN SALUD PÚBLICA}

Desde la década de los 80, los hongos han surgido como los mayores agentes causales de infecciones humanas, especialmente en pacientes con el sistema inmune comprometido y hospitalizados con enfermedades graves subyacentes (Tabla 1). Varios estudios epidemiológicos sobre las sepsis causadas por hongos demuestran que el número de casos de esta enfermedad en EEUU se ha incrementado en un $207 \%$ entre 1979 y 2000 . Además, se han descrito altos porcentajes de morbilidad y mortalidad asociada a estas infecciones, por lo que está claro que

Tabla1. Agentes causales de micosis oportunistas. La tabla muestra el número de casos por cada 1.000 .000 de personas por año y los porcentajes de mortalidad. Modificado de Sudbery et al. (2004).

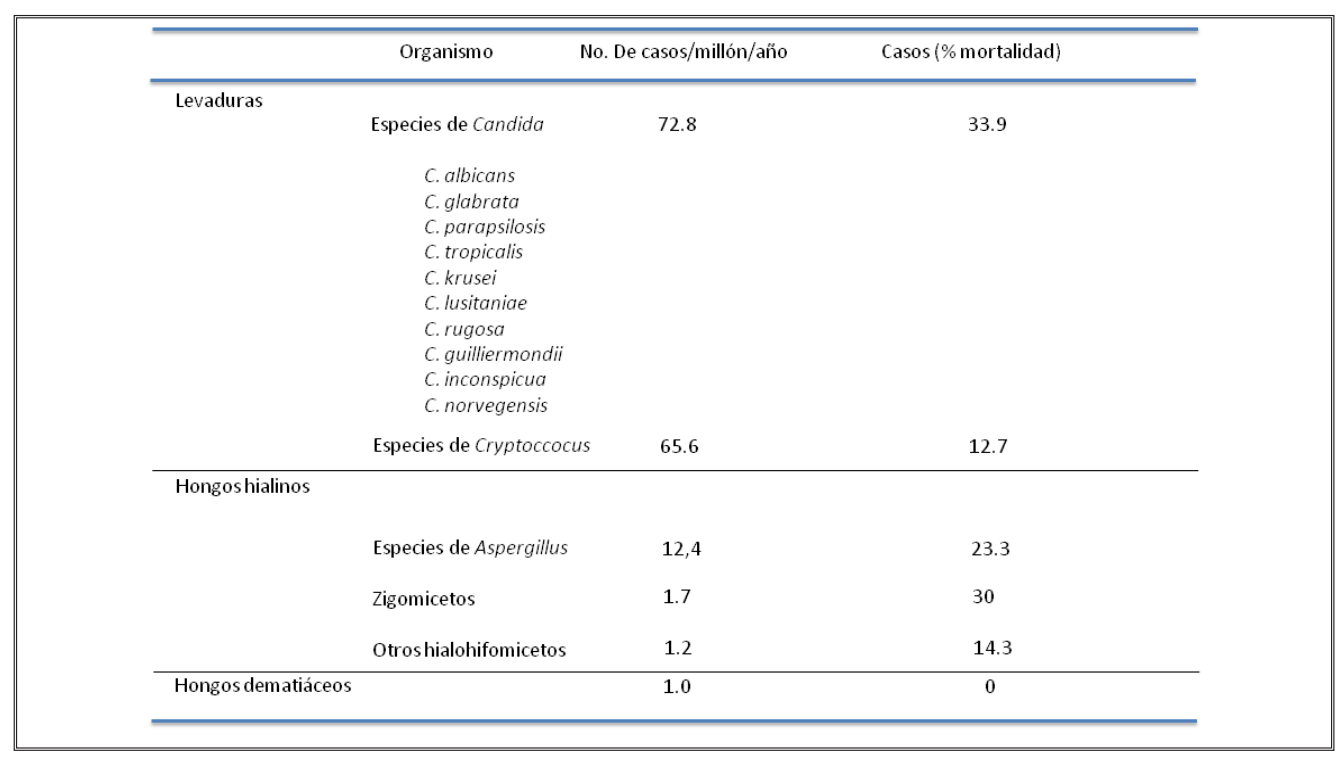


las enfermedades causadas por hongos se pueden considerar como un importante problema de salud pública (Pfaller y Diekema, 2007). Las comunidades científica y médica han clasificado estas infecciones en tres grandes grupos que incluyen las infecciones adquiridas en la comunidad, como aquellas causadas por Histoplasma spp. y Blastomyces dermatitidis, las infecciones oportunistas como la criptococosis y la aspergilosis, y las infecciones nosocomiales principalmente causadas por especies del género Candida spp.

Dentro de las infecciones causadas por Candida spp., las candidemias son las de mayor interés médico dado que han sido reportadas por muchos países alrededor del mundo como una causa muy importante de morbi-mortalidad en pacientes hospitalizados. Éstas han sido asociadas a muchos factores de riesgo como hospitalizaciones por largos periodos, terapias con antibióticos, uso de catéteres intravenosos y enfermedades subyacentes como la diabetes. La importancia de las infecciones sanguíneas causadas por algunas especies del género Candida spp. ha sido resaltada por varios estudios publicados en los últimos años. Uno de ellos llevado a cabo durante 7 años en distintos hospitales de EE.UU demostró que las especies de este género son la 4a causa más común de las infecciones sanguíneas. De igual manera, otro estudio retrospectivo realizado en ese mismo país mostró la existencia de un incremento en la mortalidad del 14,5\% en pacientes que habían sido diagnosticados con candidemias (Giri y Kindo, 2012).

El diagnostico y tratamiento apropiados, así como la prevención y el conocimiento general de la biología de las especies de Candida spp., suponen un gran reto para los médicos y microbiólogos alrededor del mundo, por lo que el estudio del género resulta una cuestión de gran importancia para la salud pública mundial.

\subsection{Candida albicans: EL HONGO PATÓGENO MÁs COMÚNMENTE AISLADO}

Se estima que existen 1,5 millones de especies de hongos, mohos y levaduras, de los cuales solamente 50 pueden ser considerados como patógenos, que en la mayoría de los casos son oportunistas. Los hongos patógenos que más afectan a la especie humana incluyen diferentes especies de los géneros Candida (dentro de ellas $C$. albicans, C. tropicalis, C. parapsilosis y C. glabrata), Aspergillus (A. fumigatus) y dermatofitos. Aproximadamente el $70 \%$ de las micosis que revisten gravedad son causadas por el género Candida y el 20\% por Aspergillus.

C. albicans es un hongo patógeno oportunista del ser humano, que en condiciones normales forma parte de la microbiota habitual del organismo, principalmente la de las membranas mucosas de los tractos gastrointestinal y genitourinario. Sin embargo, en condiciones en las que la respuesta inmune se encuentra disminuida, este hongo es capaz de invadir otros tejidos y órganos de su hospedador llegando a producir infecciones sistémicas que pueden ser de gravedad, causando incluso la muerte del paciente. La mayoría de las infecciones por $C$. albicans suelen ser de tipo endógeno, lo que significa que es la población comensal habitante en el individuo la que bajo ciertas condiciones es capaz de colonizar el organismo. Se han reconocido una serie de factores que han posibilitado el incremento de la incidencia en los últimos años dentro de los que se incluyen alteraciones de las barreras físicas mucocutáneas, implantación de prótesis o trasplantes de órganos, enfermedades subyacentes como la diabetes, neoplasias o el $\mathrm{VIH}$, y tratamientos médicos como quimioterapias o el uso de antibióticos de amplio espectro, los cuales reducen la flora habitual eliminando así los competidores. Todo ésto ha hecho que $C$. albicans, además de ser la especie más frecuentemente aislada de su género (Fig. 1), también sea en la actualidad el hongo patógeno más frecuentemente aislado en hospitales, llegando a constituir más del 48\% de los aislados clínicos en candidemias en la Unión Europea (De Luca et al., 2012; Tortorano et al., 2006). 


\subsubsection{El genoma de C. albicans.}

C. albicans es un organismo diploide obligado para el cual aún no se ha descrito un ciclo sexual completo lo que conlleva a que su propagación sea netamente clonal. A pesar de su ciclo de vida asexuado, el hongo muestra una importante variación cariotípica, la cual aunque podría suponer un problema en organismos que realizan meiosis, resulta aceptable para poblaciones que se propagan clonalmente, siempre y cuando la progenie sea viable (Chibana et al., 2000).

Una de las características más importantes del genoma de C. albicans es la enorme cantidad de diferenciaciones que sufre en la estructura y número de sus cromosomas, las cuales le garantizan una importante diversidad genética como consecuencia de procesos como polimorfismos longitudinales de los cromosomas, translocaciones recíprocas, pérdida de cromosomas o ganancia de uno de ellos (trisomías). Todas estas alteraciones le permiten realizar cambios fenotípicos que constituyen una importante estrategia adaptativa para su supervivencia en diferentes nichos.

Otra característica importante del genoma del género Candida es que en muchas de sus especies (como $C$. albicans o C. glabrata) el codón CUG, que en otras especies normalmente codifica para leucina, codifica para serina. Este ambigüedad en el uso del codón CUG puede permitirle a C. albicans que bajo condiciones de estrés, disminuya la tasa de síntesis de proteínas e induzca la expresión constitutiva de la maquinaria de respuesta a estrés. Así, una respuesta permanente al estrés celular se traduce en una mejor adaptación del hongo a cambios medioambientales repentinos y severos como en los casos de choque térmico (Santos et al., 1999). De este modo, la diversidad y versatilidad que presenta el genoma de $C$. albicans constituyen la principal herramienta de adaptación a un sinfín de nichos de los cuales ha sido aislado.

\subsubsection{Ciclo Biológico de C. albicans.}

Durante el transcurso de su evolución, C. albicans y S. cerevisiae divergieron de un ancestro común hace 200 millones de años, y desde entonces han sido capaces de adaptarse a diferentes hábitats. Así, mientras que $S$. cerevisiae vive en nichos con altas concentraciones de azucares, $C$. albicans se ha adaptado a vivir en animales de sangre caliente llegando a ser parte de la microbiota normal de sus hospedadores. Esta trayectoria evolutiva como organismo comensal le ha permitido a $C$. albicans desarrollar una serie de características que le confieren la capacidad de adaptarse rápidamente a los estímulos ambientales $\left(\mathrm{pH}\right.$, presión de oxígeno, $\mathrm{CO}_{2}$, temperatura y suero sanguíneo) a los que está sujeto durante la colonización de nuevos nichos en el hospedador (Biswas et al., 2007). Esta habilidad adaptativa le permite realizar numerosas transiciones morfológicas (Levadura-hifa, células "white"-células "opaque", etc), en las que la célula cambia de forma reversible su morfología y fisiología. Esta capacidad de realizar cambios morfogenéticos reversibles es importante para la virulencia de $C$. albicans en los modelos de infección sistémica.

C. albicans se reproduce asexualmente mediante divisiones mitóticas clonales por gemación y mediante un ciclo sexual del que por el momento se desconoce la fase haploide (Fig. 2). Esta peculiaridad que impide usar herramientas de genética clásica, sumado al hecho de que hasta hace muy poco no existieran

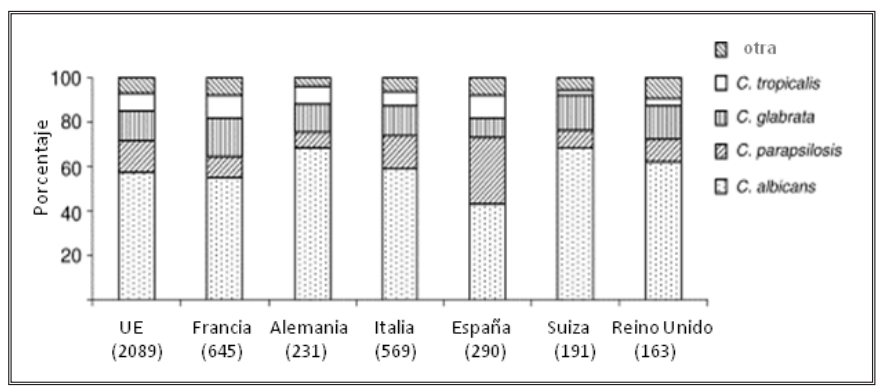

Figura 1. Distribución de especies de Candida en candidemias. Datos de los porcentajes de especies del género Candida spp, presentados por la Confederación Europea de Micología Médica (ECMM). Los números en paréntesis indican el número de pacientes. Modificado de Tortorano et al. (2006). 


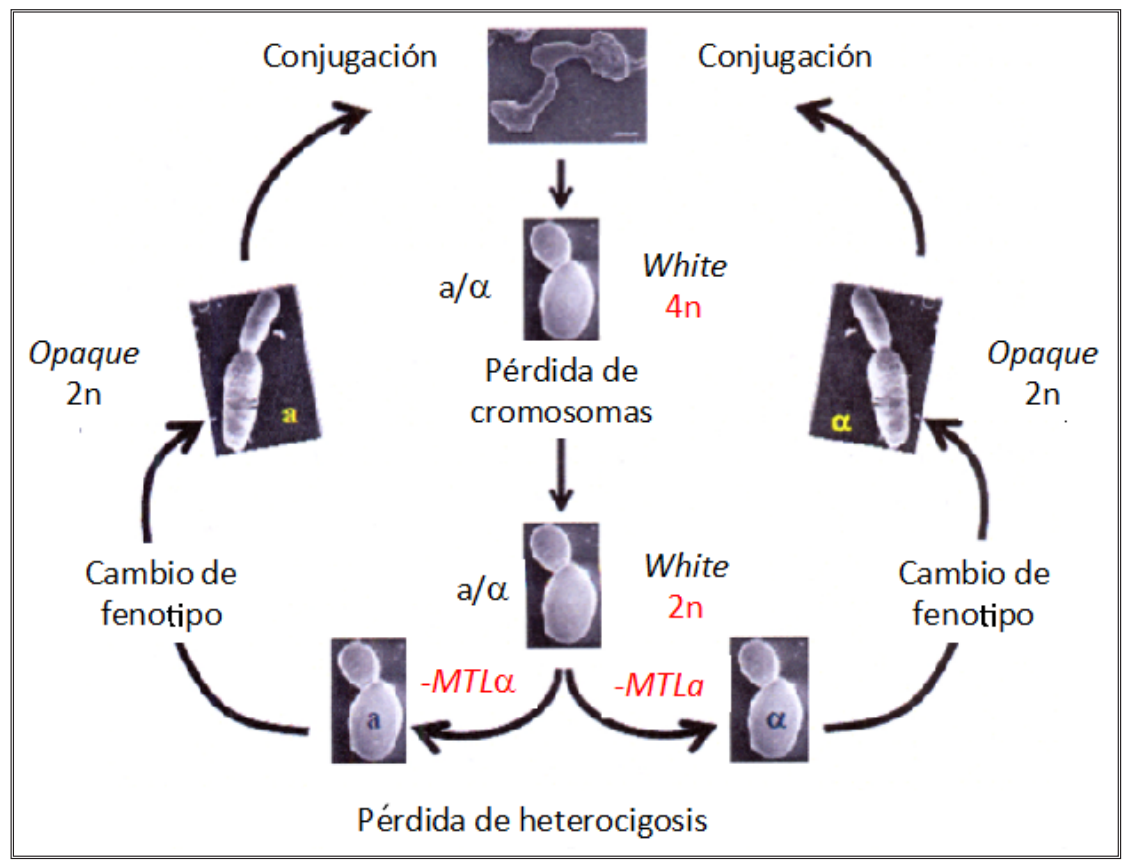

Figura 2. Ciclo parasexual de $\boldsymbol{C}$. albicans. Las células diploides $(2 n)$ son heterocigotas para el locus MTL $(\alpha / a)$. Para iniciar el ciclo es necesario que se pierda la heterocigosis del locus MTL. Posteriormente, con una frecuencia de $10^{-4}$, células $\alpha$ y a realizan un cambio epigenético de células "white" a "opaque", transición que conlleva la modificación de la transcripción de más de 400 genes. Por último, las células diploides "opaque" $\alpha$ y a conjugan para dar lugar a un tetraploide $4 n$, que se estabiliza en un estado diploide mediante pérdida de cromosomas. Imagen cortesía del Dr. Jaime Correa Bordes.

las herramientas moleculares necesarias (como vectores, promotores regulables, marcadores de selección y etiquetas moleculares), ha dificultado aún más el trabajo en el laboratorio con el hongo, por lo que a pesar de la fascinante historia natural y la importancia médica de este organismo, todavía no ha podido ser estudiado en detalle como ocurre con otros modelos de investigación.

\subsubsection{Candida albicans es un hongo pleomórfico.}

El termino pleomórfico se emplea comúnmente para designar la capacidad que poseen ciertos hongos para desarrollarse en varias morfologías como respuesta a estímulos ambientales. Bajo este concepto, $C$. albicans puede ser considerado como un organismo pleomórfico, dado que posee la habilidad de crecer en tres morfologías bien definidas: levaduras, pseudohifas e hifas (Fig. 3). Las levaduras son formas redondeadas unicelulares que se dividen por gemación y se separan al finalizar la citoquinesis. Las hifas son estructuras multicelulares que presentan un crecimiento hiperpolarizado dando lugar a filamentos en los que las paredes laterales del filamento se mantienen paralelas a nivel del septo. Las pseudohifas se presentan como una forma intermedia entra levaduras e hifas y se caracterizan por presentar constricciones en los planos de división de los diferentes compartimentos celulares y por crecer de forma ramificada. En cada uno de los tres tipos celulares se observa un núcleo por célula (Sudbery et al., 2004).

Varias evidencias sugieren que existen dos patrones diferentes de desarrollo entre hifas y pseudohifas. Primero, mientras que en las pseudohifas la división es sincrónica entre la célula madre y la hija, en las hifas la división es asincrónica puesto que la célula subapical (madre) se encuentra parada en la fase G1 mientras que la célula apical progresa sin problemas a lo largo del ciclo (Kron y Gow, 1995). Segundo, en

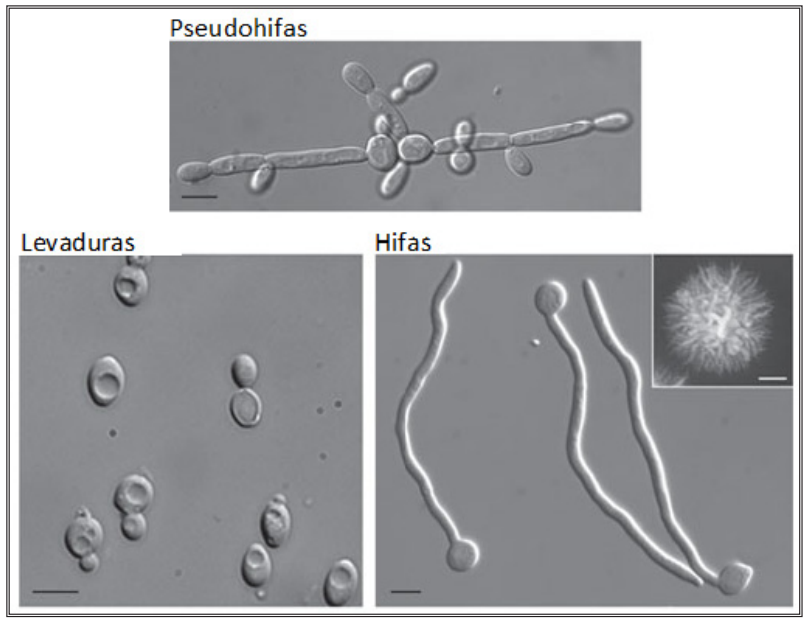

Figura 3. Distintas morfologías de $\boldsymbol{C}$. albicans. Microscopía en campo claro de diferentes formas de $C$. albicans. El panel inferior derecho muestra las hifas después de 5 días creciendo en medio Spider y su respectiva colonia. Modificado de Sudbery (2011). 
pseudohifas el primer anillo de septinas se ensambla en el cuello entre la célula madre y la célula hija (Fig. 4A), mientras que en hifas lo hace dentro del tubo germinal de la hifa a una distancia de aproximadamente $15 \mu \mathrm{m}$ de la célula madre (Fig. 4B y 4C). Otra diferencia entre estas dos formas de crecimiento se encuentra en la primera mitosis, pues mientras que en pseudohifas la división del núcleo ocurre en el cuello entre la célula madre y la célula hija, en hifas el núcleo migra por el tubo germinal hasta la posición que ocupa el primer anillo de septinas y allí ocurre la segregación nuclear. Al terminar la mitosis, un núcleo queda en la célula apical y el otro regresa a la célula madre levaduriforme (Fig. 4). Aunque la mitosis ocurre en la posición del anillo de septinas, éste no es necesario para que se complete la división nuclear, pues to que mutantes con deficiencias en la estructura del anillo de septinas (como gin $4 \Delta / \Delta$ ) son capaces de realizar mitosis (Wightman et al., 2004).

Pseudohifas e hifas también difieren en cuanto a las estructuras que controlan el crecimiento polarizado. Así, mientras que en pseudohifas y en levaduras el crecimiento polarizado está dirigido por un complejo multiproteico que se localiza en el córtex celular denominado polarisoma (el cual incluye proteínas como Bud6, Spa2 y la formina Bni4) (Evangelista et al., 1996), en hifas está dirigido por otra estructura diferente denominada Spitzenkörper (del alemán "cuerpo apical")(Crampin et al., 2005; Warenda y Konopka, 2002). Estudiar el pleomorfismo es importante debido a que al tratarse de un proceso de diferenciación celular que no es esencial para la viabilidad y que además es reversible, resulta un excelente modelo para la investigación sobre las bases moleculares de la diferenciación y de las relaciones estructura-función, las cuales son determinantes de la morfología celular.

\subsection{MORFOGÉNESIS EN C. albicans}

Los procesos morfogenéticos resultan como consecuencia de la polaridad celular, la cual puede ser definida como la distribución asimétrica de diferentes orgánulos y proteínas en un lugar concreto de la célula, que le permiten crecer de forma asimétrica (Fig. 5). Debido a que las distintas proteínas que definen y regulan el crecimiento polarizado se encuentran conservadas en diferentes organismos, existe la posibilidad de que los mecanismos que regulan la polaridad celular se encuentren también conservados en eucariotas, y de ahí la importancia de su estudio.

Como se comentó antes, C. albicans tiene la habilidad de crecer en diferentes morfologías (Sudbery et al., 2004). La transición del crecimiento en forma de levaduras al crecimiento en forma de hifas es inducida por estímulos ambientales que reflejan las condiciones existentes en el hospedador (temperatura de $37^{\circ} \mathrm{C}, \mathrm{pH}$ neutro ó alcalino y/o presencia de suero sanguíneo), las cuales se transmiten al interior de la célula a través de una compleja red de vías de señalización. A pesar de que en estudios recientes se ha demostrado que la transición de levadura a hifa no siempre es necesaria para la virulencia en candidiasis sistémicas (Noble et al., 2010), la morfogénesis aún es considerada como un factor de virulencia importante, como lo demuestran diferentes evidencias como el hecho de que cepas deficientes en los procesos morfogenéticos presenten una virulencia reducida en candidiasis
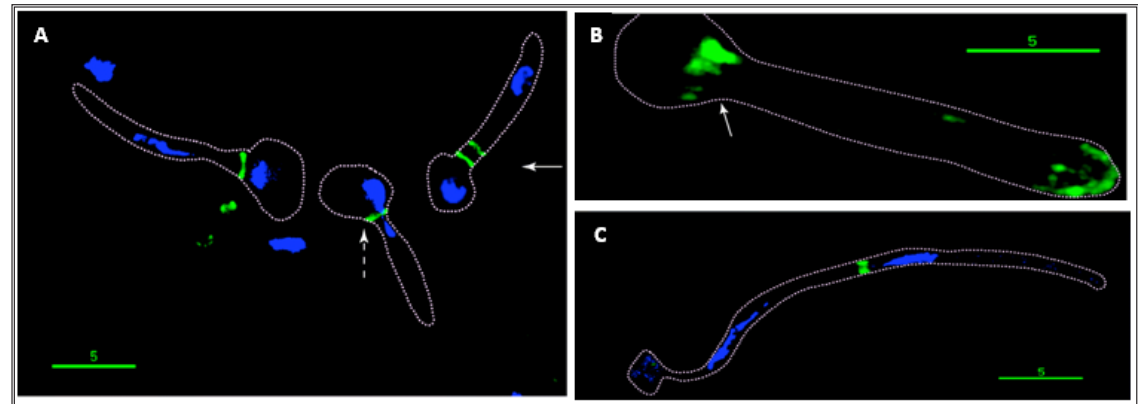

Figura 4. Pseudohifas e hifas difieren en la organización del anillo de septinas y en la posición de la primera mitosis. Fluorescencia verde: Cdc10-GFP; fluorescencia azul: núcleos teñidos con DAPI. A. pseudohifas. B. Tubo germinativo. C. hifa. En pseudohifas el primer anillo de septinas se ensambla en el cuello, mientras que en hifas lo hace en el interior del filamento. Modificado de Sudbery (2011). 


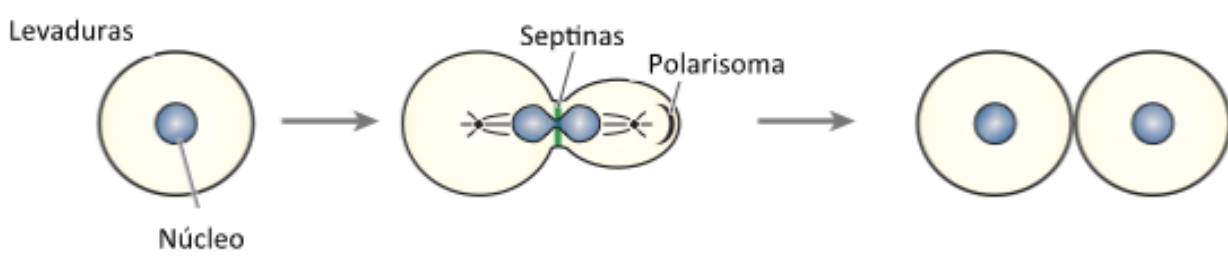

Pseudohifas

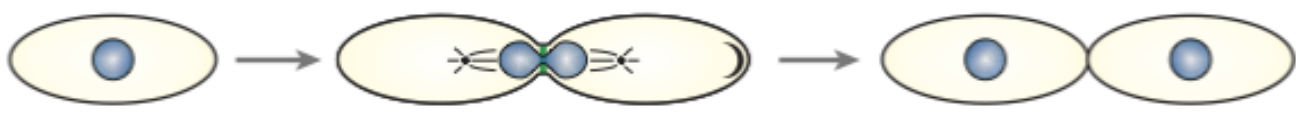

Hifas

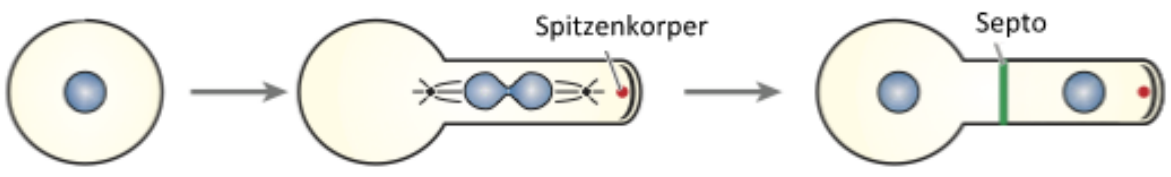

Figura 5. Crecimiento de las diferentes morfologías de $\boldsymbol{C}$. albicans. En levaduras el ciclo comienza con la formación de una nueva yema a partir de una célula madre. Cuando la yema alcanza un tamaño adecuado, los cuerpos polares del huso forman el huso mitótico que separará los cromosomas a través del cuello entre la célula madre y la hija, lugar donde se localiza el anillo de septinas (verde). En las pseudohifas, la división nuclear también ocurre en el cuello entre la madre y la hija. Esta morfología presenta células más alargadas que las levaduras, pero las células permanecen unidas después de la citoquinesis. Tanto en levaduras como en pseudohifas, el crecimiento polarizado lo determina el polarisoma. En cuanto al crecimiento hifal, depende tanto del polarisoma como del "Spitzenkörper", localizados en la punta de la hifa en crecimiento. El núcleo se divide dentro del tubo germinativo, en la posición donde se localizará el futuro septo. Tras la mitosis, uno de los núcleos regresa a la célula madre y el otro migra hacia la punta del tubo germinativo. Modificado de Whiteway y Bachewich (2007).

invasivas (Zacchi et al., 2010). Además, el desarrollo de hifas es importante para evadir a los fagocitos (Lorenz et al., 2004), escapar de los vasos sanguíneos (Phan et al., 2000) y para colonizar instrumental médico mediante la formación de biofilms (Nobile et al., 2006). A pesar de que una de las principales formas virulentas del hongo es la fase filamentosa, las levaduras también han sido aisladas de órganos infectados. Por tanto, los procesos morfogenéticos de $C$. albicans contribuyen de forma importante a la virulencia del hongo.

\subsubsection{De levaduras a hifas.}

C. albicans es un microorganismo exquisitamente adaptado para crecer en su hospedador humano; es capaz de desarrollar hifas en respuesta a una amplia variedad de condiciones ambientales las cuales reflejan la diversidad de microambientes presentes en el hospedador. Por ejemplo, la hifas se forman en respuesta a la presencia de suero, $\mathrm{pH}$ neutro, $\mathrm{CO}_{2}$ al $5 \%$ (la presión parcial del oxigeno en el torrente sanguíneo), $\mathrm{N}$-acetil-D-glucosamina (GlcNAc) y temperatura de $37^{\circ} \mathrm{C}$ (Fig. 6). La filamentación se induce también durante el crecimiento en determinados medios sólidos, como el medio Lee o el medio Spider. Estas diferentes condiciones de inducir la filamentación permiten distinguir dos condiciones diferentes del crecimiento filamentoso. La primera es la capacidad de las células para establecer y mantener el crecimiento polarizado a tiempos cortos, que ocurre en medio líquido suplementado con suero a $37^{\circ} \mathrm{C}$; la segunda es el mantenimiento del crecimiento polarizado a tiempos largos, que ocurre en los medios sólidos. De esta forma, los cultivos en medio líquido permiten analizar la habilidad del hongo para dar una respuesta rápida a estímulos ambientales e iniciar el crecimiento hiperpolarizado característico de las hifas, mientras que los cultivos en medio sólido permiten estudiar la capacidad de $C$. albicans para mantener el crecimiento hiperpolarizado en microambientes complejos y cambiantes en una colonia mientras ésta se desarrolla, así como la capacidad para invadir sustratos sólidos (Sudbery, 2011).

El cambio morfológico entre levaduras e hifas está también regulado por la interacción con la microflora acompañante. En este sentido, se han descrito algunos mecanismos sofisticados que resultan no sólo de la 
comunicación entre las células de $C$. albicans sino también de la comunicación con células bacterianas (revisado por Shareck y Belhumeur, 2011). Así, Candida es capaz de "sentir" la densidad de las poblaciones bacterianas aledañas mediante un mecanismo denominado "quorum sensing" basado en la inhibición de la filamentación mediada por el sesquiterpeno farnesol, secretado por otras células de la población (Hornby et al., 2001). En contraste, el alcohol aromático tirosol induce la formación de tubos germinativos e hifas en levaduras quiescentes (Chen et al., 2004).

\subsubsection{Ciclo celular y morfogénesis en $C$. albicans.}

El ciclo celular de C. albicans está dirigido por la proteín quinasa dependiente de ciclinas Cdc28 (también conocida como Cdk1)(Sherlock et al., 1994), homóloga a la del mismo nombre de S. cerevisiae. Cdc28 se regula por fosforilación en el residuo tirosina 18 (Tyr18) (Hazan et al., 2002), como sucede en otras especies en las que se ha estudiado. En C. albicans, Cdc28 desempeña un papel esencial en la morfogénesis de levaduras e hifas. Este hongo posee únicamente dos ciclinas de $\mathrm{G} 1$ (Ccn1 y Cln3) y dos ciclinas de G2 (Clb2 y Clb4) para regular la progresión del ciclo, a diferencia de las tres ciclinas de G1 y las seis de G2 que posee S. cerevisiae (revisado por Berman, 2006; Wang, 2009). Ccn1 está presente en las fases G1 y S temprana y es necesaria para el mantenimiento del crecimiento polarizado, pero no para su iniciación (Loeb et al., 1999). Cln3 es la única ciclina de G1 esencial, y su pérdida produce defectos en morfogénesis: las células aumentan de diámetro y crecen en forma de hifa (Bachewich y Whiteway, 2005; Chapa y Lazo et al., 2005), por lo que parece ser importante para el control del tamaño en la fase G1. De las dos ciclinas de tipo B, sólo Clb2 es esencial (Bensen et al., 2005; Ofir y Kornitzer, 2010). Clb2 y Clb4 regulan negativamente el crecimiento polarizado, aunque en diferente medida y su ausencia produce diferentes fenotipos. Las células carentes de Clb4 crecen lentamente en forma de hifas de manera constitutiva, mientras que la eliminación de $\mathrm{Clb} 2$ produce un bloqueo en anafase tardía con células alargadas y núcleos divididos conectados por husos mitóticos alargados. Por otro lado, se ha descrito que la deleción del factor transcripción Fkh2, homólogo al del mismo nombre de S. cerevisiae, donde regula específicamente la expresión de las ciclinas $B$, afecta dramáticamente a la morfología de C. albicans (Bensen et al., 2002). Además, existe otra ciclina de G1 específica de hifas, denominada Hgc1 (Li et al., 2007; Zheng et al., 2004). A diferencia del resto de los genes de ciclinas, cuya expresión está regulada a lo largo del ciclo celular, la expresión de HGC1 se activa por las señales que inducen la filamentación, lo que permite que la elongación de las hifas sea completamente independiente del ciclo celular.

En células de levaduras, los niveles de Con1 son altos en $\mathrm{G} 1$ y disminuyen en la transición $\mathrm{G} 2 / \mathrm{M}$, cuando comienza a aumentar la cantidad de Clb2 (Bensen et al., 2005; Clemente-Blanco et al., 2006). El pico de Clb4 ocurre unos 15 minutos después, y ambas ciclinas de tipo B comienzan a desaparecer en la fase $M$, cuando los núcleos se dividen. En hifas, $\mathrm{Ccn} 1$ se acumula más temprano y persiste durante más tiempo que $\mathrm{Clb} 2$ y $\mathrm{Clb} 4$,

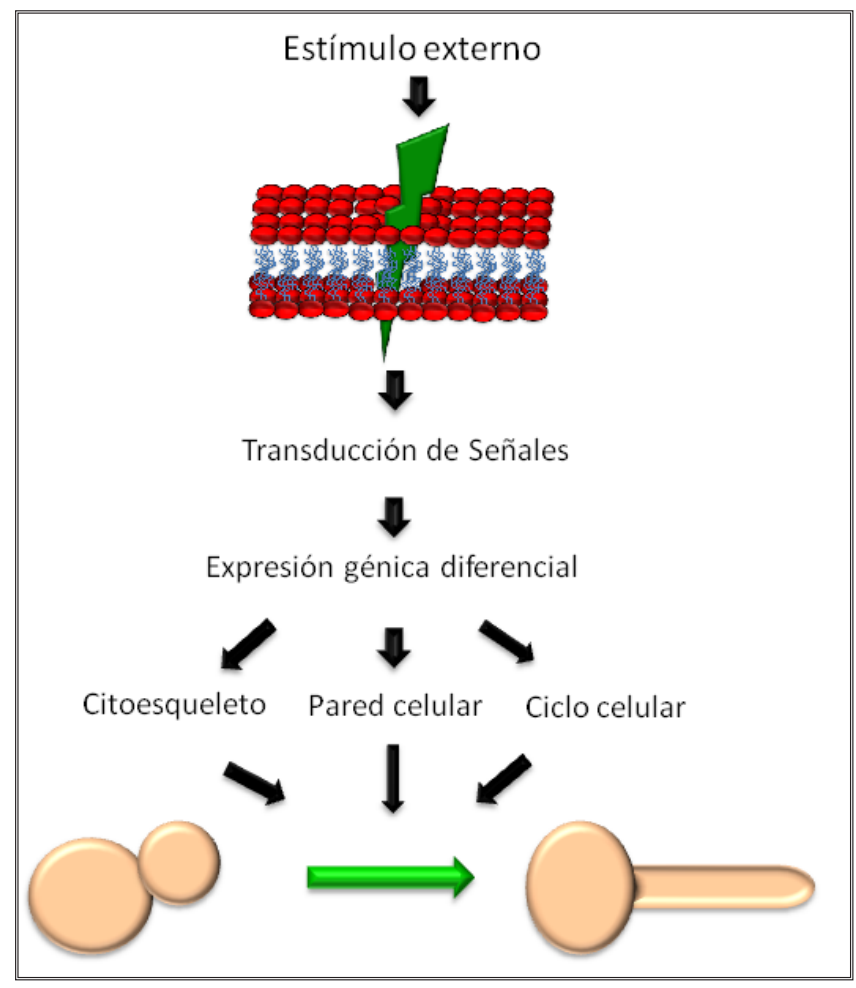

Figura 6. Esquema general de la inducción de crecimiento hifal de $C$. albicans. 
que aparecen en un momento posterior que corresponde con la fase $\mathrm{M}$, y desaparecen durante la salida de mitosis. Por tanto, el ciclo celular de hifas se encuentra retrasado con respecto al de levaduras, lo que hace que la ciclina de G1 esté presente más tiempo en hifas que en levaduras.

\subsubsection{Regulación de la transición levadura-hifa.}

La expresión de genes específicos de hifas está regulada negativamente por un complejo que incluye al corepresor transcripcional Tup1 en asociación con Nrg1 o Rfg1 (Braun y Johnson, 1997; Braun et al., 2001; Kadosh y Johnson, 2001; Kadosh y Johnson, 2005). Estos complejos son necesarios para mantener reprimida la expresión de los genes específicos de hifas durante el crecimiento levaduriforme, de tal manera que los mutantes carentes de cualquiera de ellos crecen constitutivamente como pseudohifas en las que los genes específicos de hifas están desreprimidos. La regulación de la expresión de los genes específicos de hifas es llevada a cabo por un grupo de factores de transcripción que incluyen a Efg1, Cph1, Cph2, Tec1, Flo8, Czf1, Rim101 y Ndt80 (Sudbery, 2011).

Efg1 es necesaria para la formación de hifas en respuesta a estímulos como el suero, $\mathrm{CO}_{2}$, $\mathrm{pH}$ neutro o presencia de GlcNAc en medios líquidos y también en medios sólidos (Stoldt et al., 1997). Por otro lado, Cph1 y su vía de activación sólo son necesarias para la formación de filamentos en medio Spider pero no en medio líquido (Braun y Johnson, 2000; Leberer et al., 1996), por lo que Efg1 puede ser considerado el principal regulador de la formación de hifas en respuesta a múltiples condiciones. Además, se sabe que Efg1 y Cph1 son activados por distintas vías de señalización, siendo la ruta del AMP cíclico la activadora de Efg1, mientras que Cph1 depende de la ruta de las MAPK quinasas (Leberer et al., 2001). Estas dos vías son a su vez activadas mediante estimulación por parte de la proteína Ras1 (Feng et al., 1999) (Fig. 7).

C. albicans posee una única forma de la adenilato ciclasa codificada por el gen CYR1/CDC35. Cyr1 integra una serie de estímulos ambientales, siendo esencial para el crecimiento filamentoso pero no para el crecimiento en forma de levaduras. Dos vías de señalización convergen en Cyr1 cuando se induce la filamentación con suero. La primera vía es a través de Ras1, que se une a un dominio de unión a Ras presente en Cyr1 (Fang y Wang, 2006); en la segunda vía, el peptidoglicano bacteriano (que está presente en el suero) estimula directamente a Cyr1 de forma independiente de Ras1, mediante la unión a un dominio rico en leucinas (“Leucine-Rich Repeat") similar al que presentan proteínas de la respuesta inmune innata de organismos superiores, como los receptores similares a Toll (TLR1) (Xu et al., 2008).

Un requisito necesario en todas las condiciones que inducen filamentación es la incubación a temperaturas elevadas. El sensor de la temperatura es la proteína Hsp90 (implicada en la respuesta a choque térmico), que se inactiva a $37^{\circ} \mathrm{C}$ y libera la inhibición que mantiene sobre Ras1 durante el crecimiento a temperaturas inferiores. La señalización por parte de Hsp90 requiere que la vía del AMP cíclico se encuentre intacta, pues mutaciones en cualquiera de los componentes que se encuentran por encima de Efg1 bloquean la inducción de hifas mediada por la inhibición de Hsp90 (Shapiro et al., 2009).

\subsubsection{Dianas esenciales de las vías de transducción de señales en la morfogénesis de hifas.}

Las rutas de señalización descritas en el apartado anterior convergen en la activación del programa transcripcional específico de hifas. Mediante análisis por "microarrays" se ha analizado el conjunto de genes que se inducen durante la formación de filamentos a $37^{\circ} \mathrm{C}$ en presencia de suero (Kadosh y Johnson, 2005; Nantel et al., 2002). Los genes que más se expresan son los que codifican para la proteína Hwp1 (una proteína de la pared celular específica de hifas), las aspartil proteasas secretadas (Sap4, Sap5 y Sap6), la adhesina Als3 y la proteína 1 de 


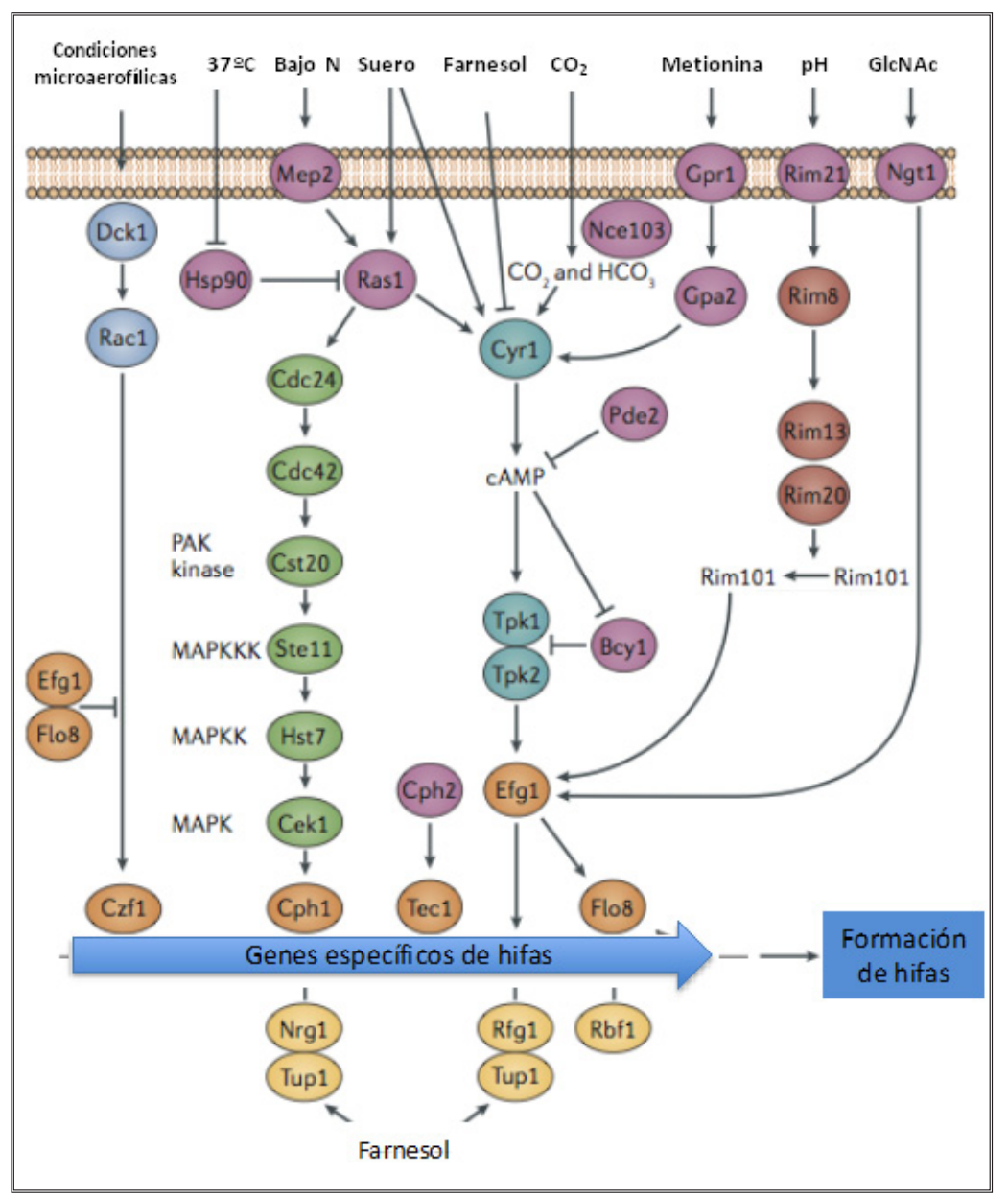

Figura 7. Rutas de transducción de señales que activan la expresión de los genes específicos de hifas. Varias señales ambientales activan la transcripción de genes implicados en la formación de filamentos, a través de múltiples rutas de señalización. También se muestran los reguladores negativos como Tup1, Rfg1, Nrg1 y Rbf1. elongación celular (Ece1), de función desconocida. A pesar de que estas proteínas otorgan a las hifas un conjunto de características que son importantes para su virulencia, no se ha demostrado que por sí solas sean importantes para establecer y mantener el crecimiento filamentoso. Sin embargo, otros tres genes que se inducen son necesarios para la formación de las hifas: UME6, HGC1 (el gen de la ciclina de G1 de hifas) y EED1. De estos, las proteínas codificadas por los genes UME6 y EED1, que están regulados negativamente por Tup1 y Nrg1, son necesarias para mantener el crecimiento polarizado (Banerjee et al., 2008; Carlisle et al., 2009; Martin et al., 2011). Por otro lado, la ciclina Hgc1 forma un complejo con Cdc28, el cual cumple con múltiples funciones durante el crecimiento hifal como establecer el crecimiento polarizado, inhibir la separación celular y evitar que el crecimiento

isotrópico vuelva a activarse. Se sabe que este complejo requiere de Ume6 para su correcta expresión, aunque su inducción inicial dependa de una vía de señalización alternativa (Carlisle y Kadosh, 2010). La expresión especifica de hifas de Hgc1 proporciona una explicación parcial de cómo las señales provenientes de vías de transducción resultan en la activación de rutas celulares que permiten el crecimiento hifal.

\subsubsection{Crecimiento polarizado de las hifas.}

Actualmente se piensa que el crecimiento de las hifas está mediado por una exocitosis polarizada dependiente del citoesqueleto en la punta de la hifa y por fuerzas de expansión citoplasmáticas que empujan el citoplasma contra la pared apical flexible (revisado por Bartnicki-Garcia, 2002). Las vesículas de secreción aportan la membrana necesaria para la expansión de la membrana plasmática y las enzimas implicadas en la síntesis de la nueva pared celular. Las vesículas secretoras probablemente viajan a lo largo de los cables de actina, que se polarizan hacia la punta. La formina Bni1 y proteínas asociadas a vesículas, como Sec4, Mlc1 y Sec2, se acumulan en un orgánulo específico cerca de la punta de la hifa que ha sido denominado "Spitzenkörper" (Bishop et al., 2010; Crampin et al., 2005; Jones y Sudbery, 2010), similar al que existe en hongos filamentosos (Virag y Harris, 2006). El Spitzenkörper es una región subapical rica en vesículas tanto exocíticas como endocíticas importante para el crecimiento de las hifas, y su posición en la hifa determina la direccionalidad de crecimiento (revisado por Steinberg, 2007). Puede considerarse como un centro de suministro de vesículas, que recibe vesículas liberadas desde el aparato de Golgi y genera vesículas exocíticas hacia la punta de la hifa. 
Tanto la localización de proteínas como estudios de dinámica sugieren que el Spitzenkörper es distinto del exocisto y del polarisoma. Los componentes del exocisto y del polarisoma se localizan en forma de media luna en la punta de la hifa (Crampin et al., 2005; Jones y Sudbery, 2010; revisado en Sudbery, 2011), y se piensa que el exocisto es necesario para anclar las vesículas provenientes del Spitzenkörper a la punta de la hifa. La elongación de la hifa requiere la reorganización del citoesqueleto, y en $C$. albicans el crecimiento de las hifas depende esencialmente del citoesqueleto de actina (revisado por Arkowitz, 2011; Arkowitz y Bassilana, 2011; Sudbery, 2011). Trabajos recientes sugieren que el equilibrio entre F-actina y G-actina es importante para el crecimiento de hifas a través de la regulación de la señalización de cAMP. Específicamente, la adenilato ciclasa Cyr1 forma un complejo con la proteína Cap1 y la G-actina que sintetiza cAMP tras el tratamiento con suero (Zou et al., 2010).

La endocitosis también es importante para la formación de las hifas, y los parches de actina se acumulan de forma polarizada próximos al ápice de la hifa. La deleción de los genes que codifican para numerosos componentes del sistema de endocitosis, como Sla1, Sla2, Pan1, Wal1, la verprolina Vrp1 o Myo5, producen defectos en crecimiento hifal y endocitosis (Borth et al., 2010; Oberholzer et al., 2002; Reijnst et al., 2010; Walther y Wendland, 2004). Adicionalmente, la deleción de los genes que codifican las proteínas Arp2 y Arp3 produce una incapacidad para formar hifas, aunque no bloquea completamente la endocitosis sino que la retrasa (Epp et al., 2010).

La formación de hifas es el resultado de un crecimiento apical sostenido en el tiempo, y esto necesita de la activación de la GTPasa Cdc42 en la punta de la hifa. De hecho, cepas que expresan niveles reducidos de Cdc42 o de su activador Cdc24 son viables pero incapaces de responder al suero (Bassilana et al., 2003; Bassilana et al., 2005). Además, durante la inducción de la filamentación Cdc42 y Cdc24 se localizan en la punta de la hifa (Bassilana et al., 2005; Hazan et al., 2002), lo que sugiere que la activación de Cdc42 en el ápice es necesaria para el crecimiento de la hifa. El aumento de la actividad GEF o la disminución de la actividad GAP producen una activación de Cdc42 y un incremento en la polarización del crecimiento. Existen dos GAPs para Cdc42 en C. albicans, codificados por los genes BEM3 y RGA2. Un mutante carente de ambos forma hifas en condiciones que normalmente sólo permiten la formación de pseudohifas (Court y Sudbery, 2007). Rga2 se fosforila por la quinasa Cdc28-Hgc1, y esta fosforilación previene su localización en la punta de la hifa (Zheng et al., 2007), lo que supone un mecanismo por el que un gen especifico de hifas como HGC1 puede inducir el crecimiento polarizado sostenido típico de las hifas.

\subsubsection{Ciclo celular y el crecimiento hifal en C. albicans.}

Al contrario de lo que sucede en levaduras y pseudohifas, el crecimiento polarizado en hifas es continuo durante del todo el ciclo celular, por lo que el citoesqueleto de actina permanece continuamente polarizado y el polarisoma y el Spitzenkörper están presentes en todo momento. Aunque la morfología alargada de las pseudohifas de S. cerevisiae se debe a un alargamiento de la fase G2, ésta no es la razón por la que las hifas crecen polarizadas, pues una vez que el ciclo celular ha comenzado no existen diferencias en la progresión de la fase S a G2 cuando se compara con levaduras (Berman, 2006).

Aunque la alteración en la cinética del ciclo celular no parece ser la causa del crecimiento polarizado de las hifas, una característica interesante de la biología de $C$. albicans es que un gran número de mutaciones o tratamientos con drogas que interrumpen la progresión del ciclo celular resultan en crecimiento polarizado no programado o hiperpolarizado. En algunos casos, estas alteraciones fenotípicas están acompañadas por la expresión de los genes específicos de hifas (Berman, 2006). 
Resultados de los últimos años están poniendo de manifiesto que las proteín quinasas, y en particular Cdc28, desempeñan un papel crucial en el establecimiento y mantenimiento del crecimiento polarizado de las hifas, habiéndose identificado un conjunto de dianas importantes en este proceso (revisado en Sudbery, 2011; Vázquez de Aldana y Correa-Bordes, 2012; Wang, 2009). La actividad CDK es esencial para este proceso, ya que la formación de hifas se interrumpe en las células en las que la expresión de Cdc28 está reprimida o se inhibe y las células que carecen de la ciclina Hgc1 inician los tubos germinales, pero rápidamente se despolarizan (Zheng et al., 2004). La deleción de la ciclina Ccn1 produce células con tubos germinales aparentemente normales que se extienden durante un período considerablemente más largo que los del mutante $h g c 1 \Delta / \Delta$, pero al final se despolarizan (Loeb et al., 1999). Entre las dianas importantes de la actividad CDK para el crecimiento polarizado, además del caso de Rga2 comentado previamente, también se sabe que el complejo Cdc28-Hgc1 fosforila a Sec2, el GEF de Sec4, para promover el flujo de vesículas secretoras a la punta de la hifa (Bishop et al., 2010) y a la proteína Mob2, que es la subunidad reguladora de la quinasa Cbk1 (Gutiérrez-Escribano et al., 2011) (se describirá con más detalle en el apartado 1.6).

Por su parte, el complejo Ccn1-Cdc28 también desempeña un papel importante en el desarrollo de las hifas, actuando junto con la quinasa Gin4 en la fosforilación y regulación de la septina Cdc11 (Sinha et al., 2007) y al mismo tiempo el complejo Clb2-Cdc28 regula directamente la actividad de Gin4 fosforilándola en un grupo de sitios de fosforilación localizados cerca de su dominio quinasa (Li et al., 2012a). Recientemente también se ha descrito que el complejo $\mathrm{Cdc} 28-\mathrm{Cln} 3$ regula la endocitosis mediante la fosforilación de la proteína endocítica Sla1, junto con la quinasa Prk1 (Zeng et al., 2012). La fosforilación de Sla1 por Cdc28-Cln3 estimula su posterior fosforilación por Prk1 y esto debilita la asociación con Pan1, un activador del complejo Arp2/3 que nuclea la actina. Durante la inducción de las hifas, Sla1 se defosforila rápidamente y permanece defosforilado durante el crecimiento en forma de hifa. Estos resultados establecen claramente una conexión molecular entre la actividad CDK y un componente clave de la maquinaria endocítica, poniendo de manifiesto un mecanismo por el que la endocitosis contribuye a la morfogénesis de células.

\subsection{LAS SEPTINAS}

Las septinas fueron descubiertas hace 40 años por Lee Hartwell en S. cerevisiae cuando realizaba la búsqueda de genes reguladores del ciclo de división celular $(C D C)$. Estos estudios permitieron identificar 4 genes $(C D C 3$, $C D C 10, C D C 11$ y CDC12) cuya mutación producía defectos en citoquinesis en las células (Hartwell, 1971). Estudios posteriores demostraron mediante microscopía electrónica que las proteínas codificadas por estos genes se ensamblaban en estructuras de aproximadamente $10 \mathrm{~nm}$ que rodeaban el cuello entre la célula madre y la hija (Byers y Goetsch, 1976). La utilización de técnicas de inmuno-microscopía mostró una localización en forma de anillos en el cuello de septación, razón por la cual el científico estadounidense John Pringle las denominó septinas (Haarer y Pringle, 1987). Basándose en su localización y en que los mutantes de septinas carecen de filamentos en el cuello, se concluyó que éstas son el mayor componente de los filamentos presentes en el cuello de gemación durante la separación celular.

Las septinas pertenecen a una familia de proteínas altamente conservadas en eucariotas superiores que están presentes en animales, hongos, y algas, pero, curiosamente, están ausentes en plantas. El número de genes de septinas oscila entre un mínimo de dos en Caenorhabditis elegans (UNC-59 y UNC-61) y un máximo de 14 en los seres humanos (SEPT1 a SEPT14), y en muchos organismos existen formas alternativas de procesamiento (Cao et al., 2007; Lindsey y Momany, 2006; Pan et al., 2007). Por ejemplo, a partir del gen SEPT9 se producen 18 
mRNAs diferentes y un total de 15 polipéptidos (Mcllhatton et al., 2001). Todas ellas son proteínas de unión a GTP capaces de ensamblarse formando complejos heterooligoméricos y estructuras altamente ordenadas que incluyen filamentos y anillos. Las septinas desempeñan importantes funciones durante la división celular, en la organización y dinámica del citoesqueleto, en secreción y remodelación de la membrana y se han relacionado con varias enfermedades humanas (revisado recientemente por McMurray y Thorner, 2009; Oh y Bi, 2011; Spiliotis y Gladfelter, 2012). Estas proteínas han sido reconocidas recientemente como un nuevo componente del citoesqueleto debido a su estructura en forma de filamentos, así como a su asociación con membranas celulares, filamentos de actina y microtúbulos (Mostowy y Cossart, 2012).

\subsubsection{Estructura de las septinas y filamentos.}

Todas las septinas presentan una organización y estructura común, con un dominio de unión a GTP central altamente conservado seguido por una región común a todas las septinas que ha sido denominada "elemento único de septinas" ("Septin Unique Element" o SUE), una secuencia altamente conservada que es importante para la asociación de los monómeros (Fig. 8A) (Estey et al., 2011; Pan et al., 2007; Sirajuddin et al., 2007; Versele y Thorner, 2005). Este dominio central está flanqueado por dos regiones más variables a los extremos. En el extremo amino existe una región rica en aminoácidos básicos que es necesaria para su interacción con los fosfoinositoles de membrana, mientras que con algunas excepciones en el extremo C-terminal poseen una hélice superenrollada ("coiled-coil").

A diferencia de otras proteínas que unen GTP de tipo Ras, las septinas son capaces de polimerizar y formar complejos oligoméricos básicos. En los últimos años se han obtenido grandes avances en el conocimiento de la estructura y organización de los filamentos gracias a estudios de microscopía electrónica en C. elegans y S. cerevisiae y a la resolución de la estructura cristalográfica del complejo humano formado por Sept2, Sept6 y Sept7 (Bertin et al., 2008; John et al., 2007; Sirajuddin et al., 2007; Weirich et al., 2008). Estos estudios estructurales confirmaron que la formación de complejos y filamentos depende del dominio GTPasa en lugar de los "coiled-coils", como se pensaba anteriormente. La microscopía electrónica del complejo de septinas de $C$. elegans demostró que las dos septinas están alineadas en un patrón lineal de cuatro densidades, y mediante marcaje de las distintas subunidades con la proteína fluorescente verde (GFP) se comprobó que el orden de las subunidades era UNC-59-UNC-61-UNC-61UNC-59, por lo que es no polar. La polimerización de estos tetrámeros en estructuras de orden superior se produce por interacción entre dos subunidades UNC-59, por lo que los filamentos resultantes también son no polares (John et al., 2007). Por otro lado, la resolución de la estructura cristalográfica del complejo de septinas humanas reveló que las distintas subunidades interactúan entre ellas mediante dos

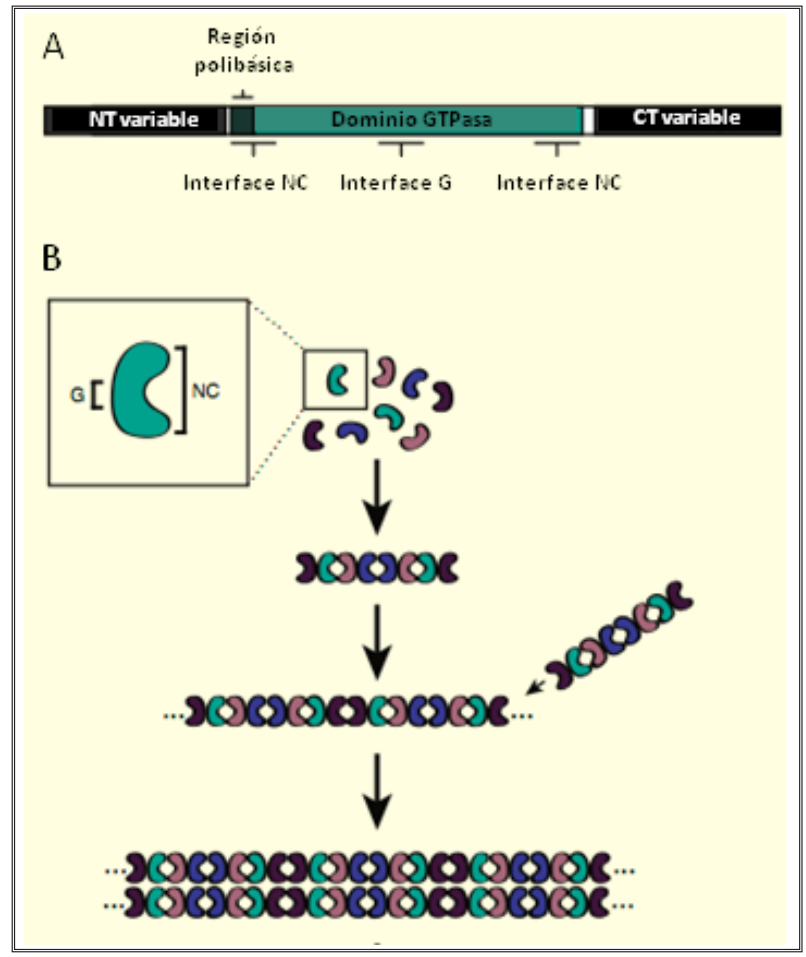

Figura 8. Complejos de septinas y el ensamblaje de sus filamentos. A. Esquema de la estructura primaria de una septina. B. Los monómeros de septinas interactúan a través de interfaces NC y G para formar complejos oligoméricos lineales no polares, que a su vez se ensamblaran en estructuras de orden superior. Tomado de Estey et al. (2011). 
interfaces diferentes: una a través del dominio de unión a nucleótidos que ha sido denominada interfaz $\mathrm{G}$ y otra que implica interacciones entre los extremos N y C terminal, llamada interfaz NC (Fig. 8B); los "coiledcoils" se extienden de forma perpendicular a la dirección del filamento. La estructura básica de los filamentos de septinas humanos es un hexámero lineal no polar (Sept7-Sept6- Sept2-Sept2-Sept6-Sept7), en el que las distintas subunidades se unen mediante interfaces G y NC que alternan (Sirajuddin et al., 2007) .

Existen evidencias de que la unión de nucleótidos y su hidrólisis desempeña un papel en la regulación de las interacciones entre las distintas septinas. Así, los diferentes estados de unión de nucleótidos de las septinas pueden ser importantes para la polimerización de sus filamentos y para las transiciones dinámicas de la estructura características del ensamblaje descrito "in-vivo" (Mendoza et al., 2002; Mitchison y Field, 2002). Varias evidencias sugieren que la hidrólisis de GTP podría regular las interacciones septina-septina mediante la inducción de cambios topológicos en las interfaces G y NC, lo que indica que los cambios dependientes de nucleótidos en la estructura habilitan o previenen la interacción entre los distintos monómeros (Sirajuddin et al., 2009). En este sentido, las septinas son diferentes a otras GTPasas, en las cuales la hidrólisis de GTP funciona solamente como un interruptor molecular.

Independientemente del organismo que se analice, las septinas se organizan bajo las mismas reglas descritas para los complejos humanos (Sirajuddin et al., 2007). En S. cerevisiae existen 5 septinas que están presentes durante el crecimiento vegetativo, codificadas por los genes CDC3, CDC10, CDC11, CDC12 y SHS1 (Hartwell, 1971; Mino et al., 1998). Además, la inducción del programa de esporulación conlleva una modificación en la composición de los anillos de septinas, puesto que dos de ellas -Cdc12 y Shs1- son reemplazas por dos septinas específicas de esporulación: Spr3 y Spr28 (De Virgilio et al., 1996; Fares et al., 1996). En este organismo, la unidad básica de polimerización es un heterotetrámero en lugar de un heterotrímero, compuesto por una molécula de cada una de las septinas Cdc3, Cdc10, Cdc11 y Cdc12 con el orden Cdc11-Cdc12-Cdc3-Cdc10. Dos de estos heterotetrámeros se asocian a su vez a través de $\mathrm{Cdc10}$, dando lugar a la unidad básica de polimerización de los filamentos, que es el octámero no polar Cdc11-Cdc12-Cdc3-Cdc10-Cdc10-Cdc3-Cdc12-Cdc11 (Bertin et al., 2008)(Fig. 9). Finalmente, la unión varios octámeros a través de la subunidad Cdc11 conduce a la formación de estructuras de orden superior, como los filamentos. Los complejos de septinas, al ser estructuras con gran plasticidad, resultan en supraestructuras de gran robustez, lo que quiere decir que si se elimina de forma individual una septina del complejo, los anillos no llegan a desorganizarse (Mino et al., 1998).

Estudios adicionales han demostrado que la composición de los heterooligómeros puede ser modificada durante el proceso de diferenciación celular, lo que sugiere que según sea la organización podrían desempeñar funciones diferentes. Tal es el caso de la septina Sept7 humana, que en fibroblastos se asocia en un complejo con Sept2 y Sept6 mientras que en neuronas se asocia en complejos diferentes (Bertin et al., 2008; Sirajuddin et al., 2007). Recientemente, un elegante estudio del laboratorio del Dr. Thorner ha demostrado que

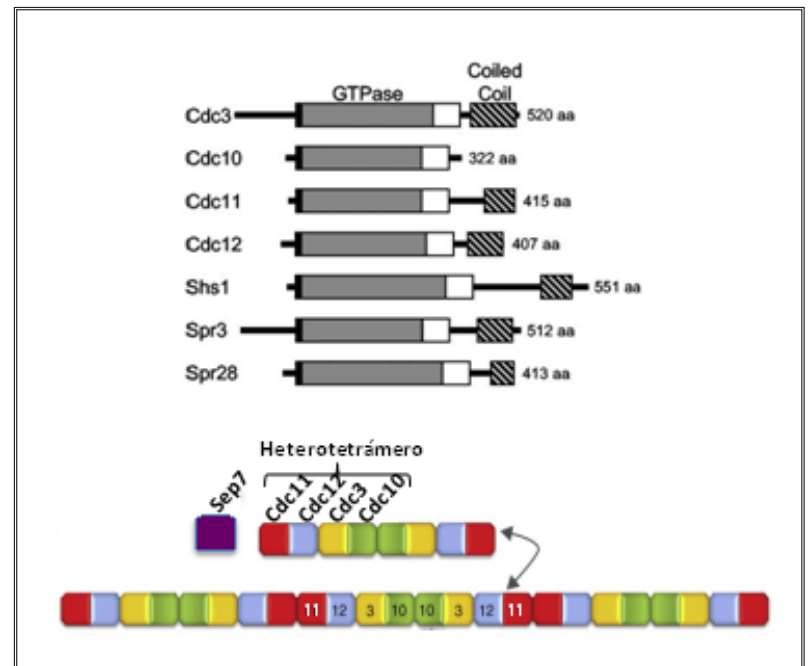

Figura 9. Septinas de $S$. cerevisiae. El panel superior muestra la estructura de las septinas de S. cerevisiae. En el panel inferior se muestra la organización de los octámeros de las septinas y su ensamblaje en filamentos. Tomado de Douglas et al. (2005) y Gladfelter et al. (2010). 
cuando la septina no esencial Shs1 sustituye a Cdc11 en el extremo de los octámeros, éstos no se ensamblan en forma de filamentos, sino que se asocian lateralmente en racimos curvados que forman anillos (Garcia et al., 2011). También demostraron que la fosforilación de Shs1 determina la capacidad de formar estructuras de orden superior.

En los últimos años se han empleado diversas técnicas para analizar la estructura de los anillos de septinas "in vivo" y complementar los estudios estructurales. Bertin y colaboradores analizaron secciones de anillos de $S$. cerevisiae mediante tomografía electrónica y crioelectrotomografía, llegando a la conclusión de que en los anillos coexisten filamentos circunferenciales y coaxiales (Bertin et al., 2012). Los filamentos circunferenciales de $10 \mathrm{~nm}$ están formados por dos filamentos apareados que se disponen perpendiculares al eje mayor, mientras que los filamentos coaxiales corresponden a filamentos individuales. Los filamentos coaxiales intersectan con los circunferenciales a intervalos regulares y posiblemente correspondan a un heterooctámero, por lo que la estructura general recuerda a la de una gasa.

\subsubsection{Importancia fisiológica de las septinas.}

La información que se ha obtenido a partir de los estudios sobre la estructura y el ensamblaje de las septinas en estructuras de orden superior ha permitido el entendimiento de las bases moleculares de su función. En la mayoría de los casos, las septinas se asocian a membranas celulares y a los citoesqueletos de actina y microtúbulos para regular una gran variedad de procesos celulares esenciales. Los estudios estructurales, junto con análisis funcionales en distintos organismos, han permitido determinar que las septinas desempeñan dos funciones principales. En las células, las septinas forman estructuras en forma de anillo en la base de cilios, flagelos, espinas dendríticas y yemas de levaduras, donde se asocian fuertemente a la membrana y forman una barrera de difusión. De esta manera, compartimentalizan la membrana en dos dominios definidos. Al mismo tiempo, los anillos de septinas actúan como organizadores corticales de los citoesqueletos de actina y microtúbulos, al reclutar a diferentes proteínas al anillo y actuar como andamios moleculares (Barral y Kinoshita, 2008; Gilden y Krummel, 2010; Gladfelter, 2010; Spiliotis, 2010; Spiliotis y Nelson, 2006; Weirich et al., 2008). Esta Introducción se centrará fundamentalmente en las funciones que desempeñan las septinas en levaduras (para revisiones más detalladas sobre la función de las septinas en células eucariotas superiores, ver Caudron y Barral, 2009; Hall et al., 2008; Saarikangas y Barral, 2011).

A. Las septinas como andamiaje subcelular. El ensamblaje altamente ordenado de la estructura de septinas les permite a estas proteínas actuar como un andamio molecular sobre el que se ensamblan otras proteínas, promoviendo así su concentración en un punto determinado de la célula y su interacción funcional. En $S$. cerevisiae, desempeñan un papel esencial en la selección del sitio de gemación (Halme et al., 1996; Roemer et al., 1996; Sanders y Herskowitz, 1996), en el posicionamiento del huso mitótico (Grava et al., 2006; Kusch et al., 2002; Merlini y Piatti, 2011), en crecimiento polarizado (Barral et al., 1999; Longtine et al., 2000) y citoquinesis (Dobbelaere y Barral, 2004; Longtine y Bi, 2003). Además, las septinas también han sido implicadas en el control del ciclo celular, en la coordinación de la respuesta al daño en DNA y en el denominado "checkpoint" de morfogénesis (Barral et al., 1999; Enserink et al., 2006; Keaton y Lew, 2006; Lew, 2003; Shulewitz et al., 1999; Smolka et al., 2006). Para regular todos estos procesos mencionados, las septinas actúan como andamios moleculares que reclutan a distintas proteínas al cuello entre la célula madre y la hija y podrían contribuir en su activación en una región concreta de la célula. 
B. Las septinas como barreras de difusión. La segunda función importante de los anillos de septinas es actuar como barreras de difusión en la membrana del cuello de las células durante el crecimiento de la yema y citoquinesis, estableciendo compartimentos diferentes en la célula madre y en la hija (Barral et al., 2000; Dobbelaere y Barral, 2004; Faty et al., 2002; Luedeke et al., 2005; Takizawa et al., 2000). Se ha demostrado que las septinas son esenciales para establecer un compartimiento específico en el cuello donde se concentran factores difusibles importantes para la citoquinesis, como la proteína Spa2, la quitín sintasa Chs2 o la proteína del exocisto Sec3 (Barral et al., 2000). También se ha descrito que las septinas impiden la difusión de las proteínas de la membrana del retículo endoplásmico a la célula hija, y que esta función depende del reclutamiento de Bud6 al cuello por parte de las septinas (Luedeke et al., 2005). Finalmente, las septinas también intervienen en el control del envejecimiento gracias a su comportamiento como barrera de difusión que impide la translocación de las proteínas del poro nuclear a la yema (Shcheprova et al., 2008).

\subsubsection{Regulación del anillo de septinas en S. cerevisiae.}

En S. cerevisiae, las septinas sufren cambios a lo largo del ciclo celular que incluyen la modificación de sus estructuras supramoleculares y modificaciones post-traduccionales, como fosforilaciones y SUMOilaciones. La organización de las estructuras supramoleculares comienza durante las fases G1 y S, cuando las cinco septinas mitóticas se acumulan en un punto del córtex que determina el futuro sitio de gemación. Este proceso depende de la GTPasa Cdc42, que se encarga de organizar a las septinas en una estructura difusa denominada "cap" (Cid et al., 2001; Gladfelter et al., 2001; Iwase et al., 2006). En un primer momento, los complejos de septinas son reclutados al sitio incipiente de formación de la yema para aumentar la concentración local de los filamentos de septinas, formando un patrón punteado y desorganizado. Este reclutamiento inicial depende de Cdc42 y parcialmente de Gic1 y Gic2, un par de efectores de Cdc42 (Cid et al., 2001; Iwase et al., 2006). Una vez reclutadas al sitio de gemación, los complejos de septinas se asocian con la membrana plasmática gracias a la interacción de los motivos poli-básicos de las septinas y los fosfolípidos de membrana (Bertin et al., 2010; Casamayor y Snyder, 2003; Zhang et al., 1999). Entonces sufren un cambio en la organización y pasan a formar un anillo de aproximadamente $1 \mu \mathrm{m}$ de diámetro, cambio que requiere la hidrólisis del GTP unido a Cdc42 y sus factores GAP (Caviston et al., 2003; Gladfelter et al., 2002; Kadota et al., 2004). Tras la emergencia de la yema, el anillo de septinas se convierte en una estructura estable en forma de reloj de arena en el cuello entre la célula madre y la hija que ha sido denominada collar. Finalmente, antes de la citoquinesis el collar se divide dando lugar a dos anillos que flanquean la región donde se va a formar el septo de división. Cuando la formación del septo se completa y las células comienzan una nueva fase G1, los dos anillos se desensamblan para volver a formarse en el futuro sitio de gemación (Fig. 10A).

Análisis mediante experimentos de FRAP ("Fluorescence Recovery After Photobleaching") han puesto de manifiesto que los anillos de septinas presentan dos estados dinámicos diferentes, dependiendo de la fase del ciclo en la que se encuentren. Así, durante la mayor parte del ciclo, los anillos de septinas se encuentran en un estado denominado estático o congelado ("frozen"), en el que no se detecta difusión lateral dentro de la subunidades de la estructura. Del mismo modo, se ha demostrado la existencia de otro estado denominado fluido ("fluid"), en el que las septinas se mueven y reorganizan dentro del anillo, el cual coincide con la emergencia de la yema y con la citoquinesis (Fig. 10A). Estas modificaciones dinámicas de las septinas se encuentran reguladas al menos en parte, por el estado de fosforilación de Shs1 (Dobbelaere et al., 2003).

La transición desde la estructura en forma de reloj de arena o collar al doble anillo viene acompañada de cambios en la orientación de los filamentos de septinas. Así, cuando éstos se encuentran en la estructura de 


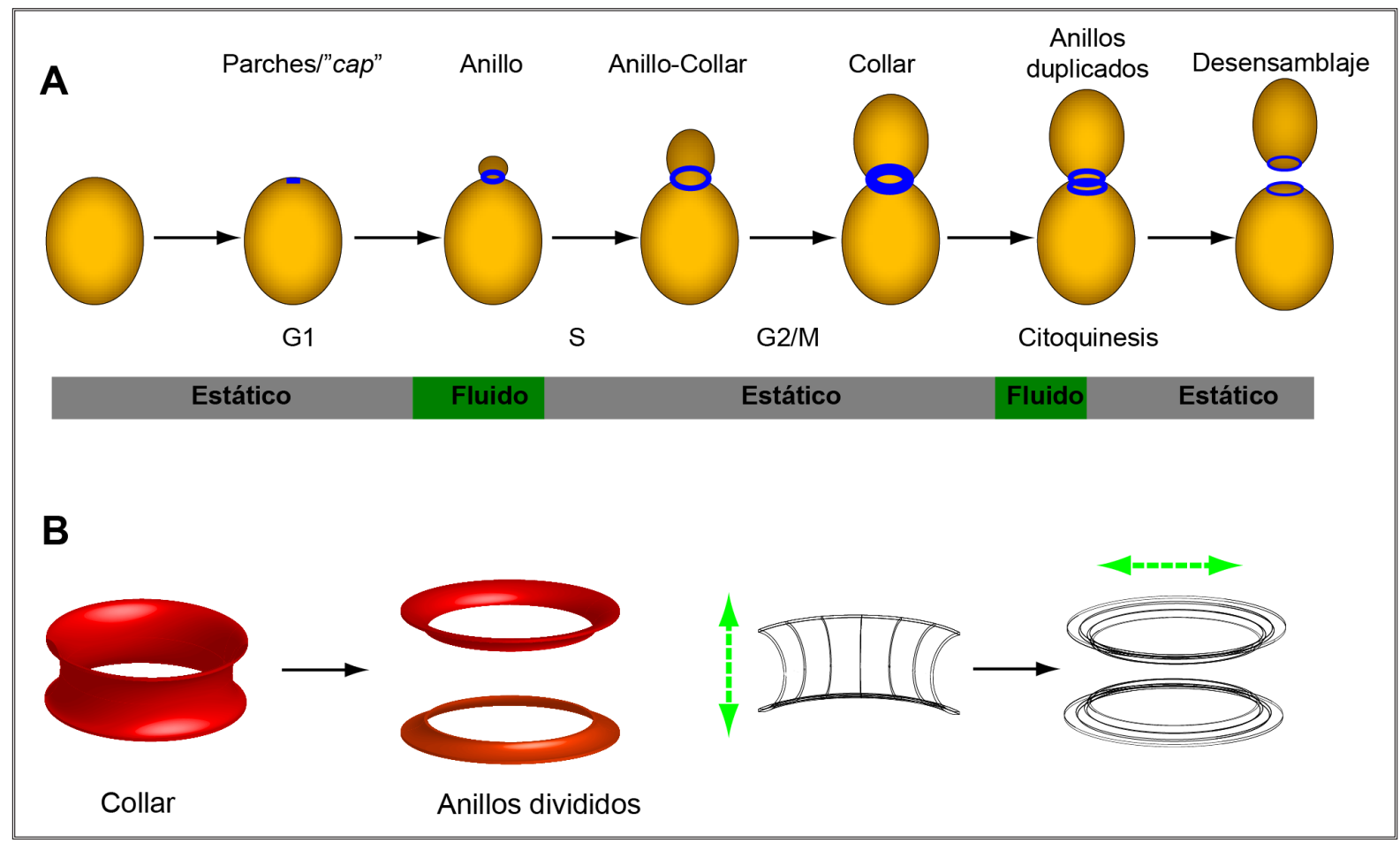

Figura 10. Dinámica de las septinas en S. cerevisiae. A. La dinámica de las subunidades de septinas en el anillo es dependiente de ciclo celular. Los únicos momentos de fluidez del anillo coinciden con cambios en la topología de la membrana plasmática, emergencia de la yema y citoquinesis. La barra representa la distribución de los estados estático (gris) y fluido (verde) a lo largo del ciclo celular. B. El anillo de septinas es dinámico en si mismo. La división en dos del anillo (panel izquierdo) viene acompañada de una rotación de $90^{\circ}$ de los filamentos de septinas para localizarse en paralelo al septo (panel derecho). Tomado de González-Novo et al. (2009).

collar, la orientación de los filamentos de septinas es paralela al eje célula madre-hija, mientras que durante la citoquinesis experimentan un giro de $90^{\circ}$, disponiéndose de forma perpendicular al eje mayor (Fig. 10B)(DeMay et al., 2010; Vrabioiu y Mitchison, 2006; Vrabioiu y Mitchison, 2007). El hecho de no encontrar evidencias de que estas estructuras se desensamblen durante estas reorganizaciones, indica que son estructuras supramoleculares muy plásticas y admiten la formación de topologías muy complejas y diversas.

Durante los últimos años se ha puesto de manifiesto que las septinas sufren una serie de modificaciones posttraduccionales, que a menudo tienen importantes efectos en el ensamblaje y función de las septinas. Los tres tipos de modificaciones más comunes son la fosforilación, acetilación y SUMOilación (revisado en HernándezRodríguez y Momany, 2012). La primera modificación que se identificó en las septinas de S. cerevisiae fue la adición de SUMO ("Small Ubiquitin-related MOdifier"). Las septinas Cdc3, Cdc11 y Shs1 sufren esta modificación en la transición G2/M, que se elimina posteriormente en citoquinesis (Johnson y Blobel, 1999; Takahashi et al., 1999). Mutación de todos los sitios SUMO en Cdc3, Cdc11 y Shs1 previene la desaparición de los anillos de septinas en los sitios de división previos, lo que sugiere que la SUMOilación regula el desensamblaje de los anillos tras citoquinesis. También se ha demostrado que Cdc3, Cdc10, Cdc12 y Shs1 se acetilan, y los mutantes defectivos en acetilación presentan defectos en la transición de anillo a collar y en la localización de los anillos de septinas (Mitchell et al., 2011). Es interesante que los sitios de acetilación mapeados en estas cuatro septinas flanquean los motivos más importantes que forman la interfaz G de las respectivas proteínas, por lo que es posible que estas acetilaciones influyan en el ensamblaje de los heterotetrámeros y/o su estabilidad.

La modificación más abundante y mejor caracterizada de las septinas es la fosforilación, y muchas mutaciones que afectan a estos sitios de fosforilación producen defectos en morfogénesis y citoquinesis (revisado en 
Hernández-Rodríguez y Momany, 2012). Sin embargo, no existen ejemplos de residuos que sean modificados en todas las septinas, lo que conduce a pensar que estas modificaciones post-traduccionales han evolucionado recientemente y de forma independiente para regular aspectos específicos de cada una de las subunidades. Al menos cuatro proteín quinasas desempeñan un papel importante en la regulación de las septinas. Cla4, un miembro de la familia de las quinasas PAK que se une a Cdc42, interacciona con las septinas y fosforila a Cdc3 y Cdc10 “in vitro" y posiblemente a otras septinas "in vivo" (Versele y Thorner, 2004). La fosforilación por Cla4 parece desempeñar un papel en la estabilización de los filamentos de septinas, ya que coincide con el cambio al estado congelado "in vivo" y porque las septinas permanecen en el estado fluido en el mutante cla4 $\Delta$. Otras dos quinasas que regulan las septinas son Elm1 y Gin4 (Altman y Kellogg, 1997; Asano et al., 2006; Bouquin et al., 2000; Gladfelter et al., 2004; Longtine et al., 2000; Mortensen et al., 2002; Versele y Thorner, 2004). La proteín quinasa Gin4 se localiza en el cuello de las células y se piensa que regula la función de las septinas fosforilando al menos a Shs1 (Dobbelaere et al., 2003; Longtine et al., 1998). Los mutantes gin4 $\Delta$ no forman anillos de septinas, sino que las septinas se disponen en el cuello en forma de barras paralelas al eje célula madre-hija, lo que sugiere que Gin4 podría estabilizar el anillo promoviendo la asociación lateral de los filamentos de septinas. Finalmente, las septinas también son fosforiladas por la quinasa Cdc28 para promover el desensamblaje del anillo tras la citoquinesis. La fosforilación de Cdc3 por el complejo Cln-Cdc28 en G1 parece ser necesaria para el desensamblaje del anillo, ya que el mutante cdc3-S1S2 que carece de los sitios de fosforilación para Cln-Cdc28 presenta un retraso en el desensamblaje del anillo de septinas (Tang y Reed, 2002).

En las septinas centrales (Cdc3, Cdc10, Cdc11 and Cdc12 y sus ortólogos), la fosforilación normalmente ocurre en las regiones N- y C-terminal divergentes, en las que el estado de fosforilación parece regular el ensamblaje y desensamblaje del anillo de septinas. El único ejemplo de una fosforilación que tiene lugar dentro del dominio G es Cdc10, la septina central del heterooctámero (la mayoría de las septinas de hongos posee una Gly en esta posición). La septina no esencial Shs1 es la que más modificaciones por fosforilación sufre, ya que es fosforilada en el extremo N-terminal y en 4 residuos cerca de la interfaz G (Egelhofer et al., 2008; Garcia et al., 2011). Como se ha comentado previamente, cuando Shs1 sustituye a Cdc11, los octámeros se asocian lateralmente y forman racimos curvados que se ensamblan en anillos (Garcia et al., 2011). Estos autores determinaron que la mutación fosfomimética en S259 (que se localiza en el dominio G) producía la formación de anillos y una estructura similar a una gasa con un patrón regular, lo que les llevó a sugerir que S259 podría actuar como un interruptor molecular para permitir cambios en la organización de las estructuras de orden superior. Adicionalmente, la mutación de 4 residuos de Ser localizados entre el SUE y el "coiled-coil" producía anillos menos organizados y la adición de otros 4 residuos fosfomiméticos localizados después del "coiled-coil" eliminaba completamente la capacidad de los octámeros para formar anillos, por lo que ha propuesto que la fosforilación del extremo C-terminal de Shs1 regula negativamente la formación de anillos de septinas. Es interesante que en Ashbya gossypii Shs1 también se fosforila en el extremo C-terminal. La generación de mutantes fosfomiméticos en 9 de estos sitios produce un fenotipo dominante letal, por lo que no se ha podido determinar su significación biológica, pero la deleción de la región C-terminal que contiene todos estos sitios genera anillos de septinas expandidos y estructuras de septinas ectópicas (Meseroll et al., 2012). Estos resultados son consistentes con la idea de que la fosforilación del extremo C-terminal de Shs1 regula negativamente la formación de anillos en S. cerevisiae y A. gossypii.

Por otro lado, la fosfatasa PP2A unida a Rts1, una subunidad reguladora de tipo B, está implicada en la defosforilación de las septinas. PPA2-Rts1 se localiza en el cuello de la célula después de la división del anillo de septinas, y al mismo tiempo los anillos de septinas en el mutante $r t s 1 \Delta$ son más estables (Dobbelaere et al., 2003). 


\subsubsection{Las septinas de $C$. albicans.}

La secuenciación completa del genoma de este patógeno reveló la existencia de 7 genes codificantes de septinas, los cuales mostraron tanto en secuencia nucleotídica como aminoacídica, un alto grado de conservación con sus homólogos en S. cerevisiae, por lo que fueron denominados de la misma forma (excepto SHS1, que en C. albicans se conoce como SEP7). De ellos, solamente CDC3 y CDC12 son esenciales para crecimiento de las células. Los genes CDC10 y CDC11 no son esenciales en C. albicans. Sin embargo, las células carentes de estas dos septinas presentan defectos morfológicos durante el crecimiento en forma de levaduras y dan lugar a filamentos más curvados que las cepas silvestres cuando se induce la filamentación, lo que indica que las septinas son necesarias para mantener la estabilidad del eje longitudinal del crecimiento polarizado (Warenda y Konopka, 2002). Así mismo, se demostró que los genes SPR3 y SPR28, ortólogos a los genes que codifican las septinas específicas de esporulación, no se expresan en las condiciones ensayadas de crecimiento levaduriforme e hifal. Además, se demostró que los mutantes de septinas muestran defectos en el crecimiento invasivo y en virulencia en modelos de ratón (González-Novo et al., 2006; Warenda et al., 2003). Mediante purificación de los complejos de septinas en hifas y levaduras y análisis por espectrometría de masas, se ha comprobado que la composición de los anillos es similar en ambas morfologías y presenta una estequiometría de 2 moléculas de Cdc3, 1-2 de Cdc10, 1 de Cdc11, 2 de Cdc12 y $\leq 1$ de Sep7 (Kaneko et al., 2004).

En C. albicans, las septinas también se regulan por modificaciones post-traduccionales de las distintas subunidades y en distintos momentos del desarrollo morfogenético. A pesar de los serios esfuerzos para tratar de identificar septinas SUMOiladas en C. albicans, no se ha detectado esta modificación ni en hifas ni en levaduras (Martin y Konopka, 2004). Sin embargo, si existe un homólogo de SUMO (Smt3), que se localiza preferentemente en el lado de la célula madre del anillo de septinas y algunas proteínas que contienen Smt3 inmunoprecipitan con Cdc11. Por tanto, en C. albicans son las proteínas asociadas a las septinas, y no las propias septinas, las que se modifican por SUMO de forma asimétrica. La acetilación también se ha detectado en Cdc11 de $C$. albicans, tanto en hifas como en levaduras, aunque ocurre en una metionina en lugar de lisina y su función no está clara (Sinha et al., 2007). Finalmente, la fosforilación es la modificación más abundante y mejor estudiada, y se describirán en los apartados siguientes en relación con su importancia en el crecimiento polarizado y separación celular.

Durante el crecimiento levaduriforme, la dinámica y organización de las septinas es similar al patrón descrito anteriormente para S. cerevisiae, organizándose las septinas en un anillo en el cuello entre las células madre e hija que se duplica antes de citoquinesis (González-Novo et al., 2008; Sudbery et al., 2004; Warenda y Konopka, 2002). Durante esta fase de crecimiento también existen los estados congelado y fluido, que corresponden a los descritos en S. cerevisiae, pero durante la inducción del crecimiento hifal se producen cambios en la organización y en la dinámica de las estructuras de septinas (González-Novo et al., 2008; Sudbery et al., 2004). En las hifas se han descrito tres tipos de estructuras diferentes de septinas. La primera se localiza en la base del tubo germinativo cuando éste comienza a emerger y se ha denominado banda basal. Las septinas se organizan como barras paralelas al eje de crecimiento polarizado, con un patrón similar al que ocurre en los "shmoos" de S. cerevisiae. A medida que el tubo germinativo crece para formar la hifa, las septinas se localizan en el ápice, formando una estructura conocida como "cap". Finalmente, cuando la hifa adquiere una longitud determinada, parte de las septinas del "cap" quedan en las paredes laterales de la hifa y forman un anillo similar al de levaduras, que determina el plano de división donde se ensamblará el septo que divide el cuerpo del primer compartimento hifal (Sudbery et al., 2004; Warenda y Konopka, 2002). (Fig. 11).

En cuanto a las propiedades dinámicas del anillo de septinas en hifas, estudios realizados mediante FRAP han 


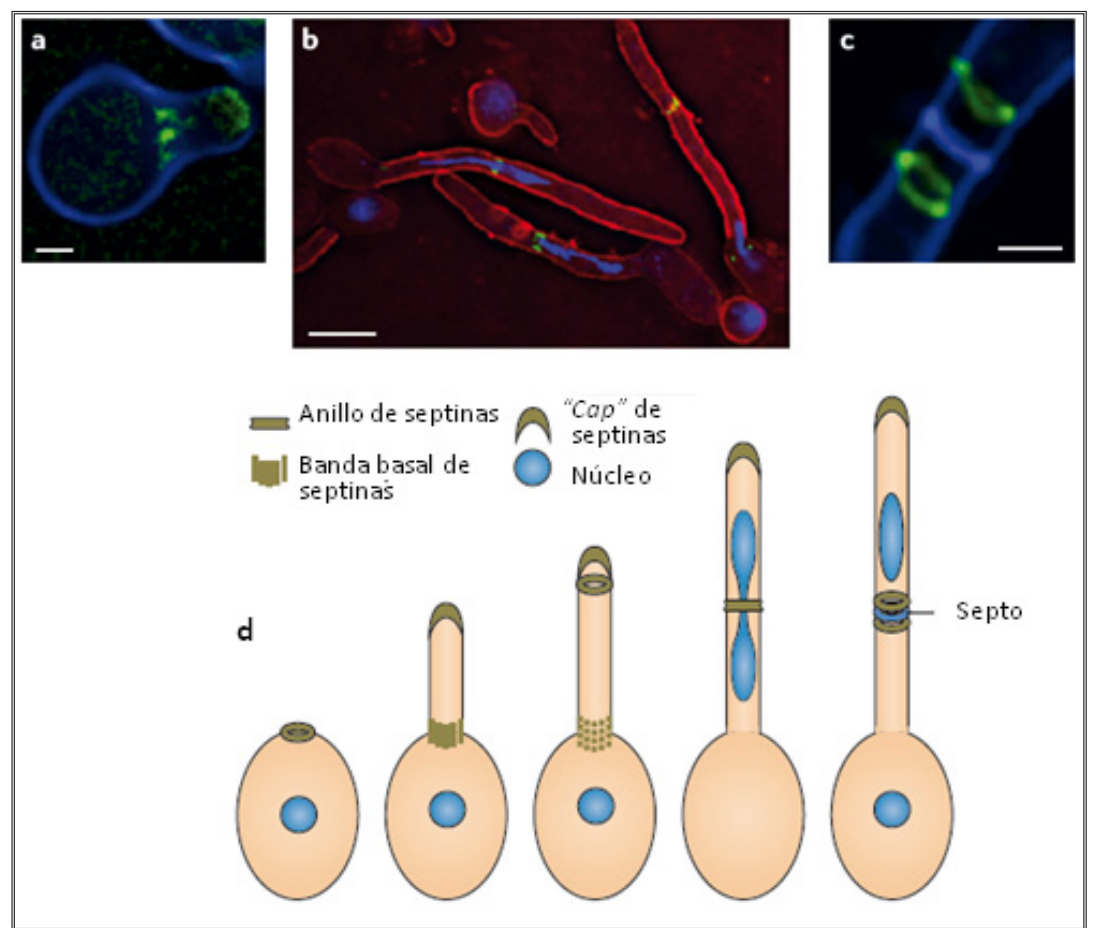

Figura 11. Biología celular del desarrollo hifal de $C$. albicans. a. En cuanto ocurre el inicio a la evaginación del tubo germinal, una banda basal de septinas se hace visible tanto en la base de esta estructura como en el "tip". Se muestra la septina Cdc10 marcada con la proteína fluorescente amarilla (YFP). El contorno de la hifa (azul) ha sido teñido con Concavalina-Alexaflúor. b. El crecimiento del tubo germinativo da lugar a que la banda basal desaparezca para que en su lugar se forme a un anillo de septinas en el interior de la hifa en crecimiento. En ese momento, el núcleo (teñido con DAPI; color azul) migra fuera del cuerpo de la hifa para realizar la mitosis en el tubo germinativo. La tinción con ConcavalinaTexas Red marca el contorno de las hifas. c. El anillo de septinas se divide en dos, permitiendo la formación del septo en medio de las dos estructuras. Tinción como en la figura a. d. Esquema del primer ciclo celular durante el desarrollo hifal. Tomado de Sudbery (2011)

demostrado que poseen un comportamiento dinámico específico, diferente de los estados estático y fluido de levaduras, y que ha sido denominado estado específico de hifas (HSS o "Hypha-Specific State"). A diferencia de lo que ocurre en levaduras, el estado específico de hifas se caracteriza porque las distintas septinas presentan una dinámica diferente: así, mientras que Cdc3, Cdc12 y Sep7 permanecen incorporadas de forma estable en el anillo, la septina Cdc10 es altamente dinámica y presenta una alta tasa de intercambio entre el anillo y el citoplasma (González-Novo et al., 2008). Este comportamiento dinámico de Cdc10 es dependiente de la septina Sep7 y de su fosforilación por parte de la ciclina Hgc1, ya que tanto en los mutantes $\operatorname{sep} 7 \Delta / \Delta$ como en los $h g c 1 \Delta / \Delta$ el intercambio de Cdc10 con el citoplasma se pierde. Como se comentará en apartados posteriores, este cambio en la dinámica del anillo de septinas en hifas es esencial para inhibir la separación celular durante en crecimiento filamentoso.

\subsubsection{Regulación del anillo de septinas en C. albicans.}

En Candida spp. se han descrito los mismos reguladores de las septinas que en S. cerevisiae. El ensamblaje de las septinas en el punto de gemación necesita de la señalización de Cdc42-GTP y de reguladores como las quinasas Gin4 y Cla4.

Las hifas de $C$. albicans se han utilizado como modelo para el estudio de la regulación del ensamblaje de los anillos de septinas, porque se organizan a intervalos regulares a lo largo del filamento. Como se ha comentado anteriormente, en las hifas las septinas se organizan inicialmente como una estructura asociada al ápice del filamento hasta que una señal de origen desconocido desencadena el que se queden ancladas en un punto concreto del córtex lateral de la hifa mientras que el ápice continúa creciendo (DeMay et al., 2009; Sudbery, 2001; Warenda y Konopka, 2002). Court y Sudbery han demostrado que la desregulación en los niveles de Cdc42-GTP, bien por deleción de los GAPs Rga2 y Bem3 o bien por el uso de un mutante hiperactivo (Cdc42G12V), produce la formación de anillos ectópicos en pseudohifas y/o anillos que presentan un aspecto de barras paralelas en lugar de continuos (Court y Sudbery, 2007), indicando que los niveles de activación de Cdc42 son importantes para la formación y/o maduración del anillo de septinas. De forma similar, la quinasa Gin4 también 
parece estar implicada en la transmisión de la señal que desencadena la formación del anillo de septinas en las hifas, ya que los mutantes gin $4 \Delta / \Delta$ no forman anillos estables en las hifas, aunque si son capaces de localizarse en el ápice de la hifa (Wightman et al., 2004). En C. albicans, Gin4 fosforila a Cdc11 en un único residuo que permite su posterior fosforilación en un residuo adyacente por el complejo Cdc28-Ccn1 (Sinha et al., 2007). Estas fosforilaciones son necesarias para mantener un crecimiento polarizado robusto, pero mutantes no fosforilables de Cdc11 son capaces de ensamblar anillos de septinas normales, lo que indica que deben existir otras dianas de Gin4 que son críticas para la organización y asociación de las septinas a la membrana plasmática.

Más recientemente se ha demostrado que Cdc28-Clb2 fosforila a Gin4 en un grupo de sitios consenso de fosforilación localizados antes del dominio quinasa, activando su actividad quinasa, lo que produce la fosforilación de Sep7 (Li et al., 2012a). La generación de mutantes fosfodeficientes en estos residuos impide la activación de Gin4, reduce su asociación con Sep7, altera la dinámica de Sep7 en el anillo y produce defectos en morfogénesis y citoquinesis. Por el contrario, los mutantes fosfomiméticos aumentan la actividad quinasa pero tiene defectos moderados. Es interesante que estos autores también encontraron que Gin4 tiene funciones que son independientes de su actividad quinasa durante G1, que son esenciales para el ensamblaje del anillo de septinas.

Es interesante que en otro hongo filamentoso como Ashbya gossypii, las quinasas Gin4 y Elm1 tampoco son necesarias para la unión de las septinas a la punta de la hifa, pero si para la coalescencia en barras y asociación con el córtex lateral (DeMay et al., 2009), lo que indica que estos mecanismos de regulación están conservados entre distintos hongos. Se ha propuesto que las quinasas Elm1 y Gin4 podrían regular la afinidad de las septinas por la membrana (Gladfelter, 2010). Experimentos realizados con septinas de S. cerevisiae o humanas sugieren que las septinas poseen afinidad por fosfoinositoles fosforilados (PIP) (Bertin et al., 2010; Tanaka-Takiguchi et al., 2009; Zhang et al., 1999), por lo que las quinasas Elm1 y Gin4 podrían promover la asociación de las septinas con las membranas fosforilando algunos residuos clave todavía desconocidos que incrementen su afinidad por las membranas que contienen PIP o promoviendo cambios en la composición de las membranas por activación de Mss4, la quinasa que convierte PIP en PIP2.

\subsubsection{Las septinas y el crecimiento polarizado.}

El hecho de que las levaduras de $C$. albicans posean la habilidad de polarizar rápidamente su crecimiento como respuesta a factores inductores sugiere que, además de la inducción del programa transcripcional especifico de hifas, las modificaciones post-traduccionales de proteínas previamente existentes en las levaduras son importantes para la transición levadura-hifa (González-Novo et al., 2009). Un ejemplo de esto es la septina Cdc11, cuya fosforilación en la serina 395 cerca de su extremo C-terminal por la quinasa Gin4 en el ciclo celular previo a la inducción del crecimiento hifal es necesaria para que tenga lugar otra fosforilación en la serina contigua (S394) por la quinasa Cdc28 asociada a la ciclina Ccn1. Esta modificación ocurre en los primeros 5 minutos posteriores a la inducción de las hifas y es esencial para la inducción y el mantenimiento del crecimiento hifal (Sinha et al., 2007)(Fig. 12). Así, las células deficientes en la proteína Ccn1 o mutantes que contienen un alelo fosfodeficiente de $\operatorname{Cdc11}\left(C D C 11^{5394 A}\right)$ emiten tubos germinales normales pero son incapaces de mantener el crecimiento polarizado una vez se ha formado el primer septo. En el mutante $\operatorname{ccn} 1 \Delta$, este fenotipo se suprime al introducir un alelo fosfomimético de $\operatorname{Cdc11}\left(C D C 11^{55394,395 D D}\right)$. Estos resultados ponen de manifiesto que el estado de fosforilación de Cdc11 es importante para mantener un crecimiento polarizado sostenido en el tiempo.

Una posibilidad atractiva es que la fosforilación sobre la serina 394 de Cdc11 regule la interacción del anillo 
de septinas con otras proteínas implicadas en el crecimiento polarizado, ya que una de las funciones del anillo es actuar como andamiaje para otros factores celulares. Uno de ellos podría ser el exocisto, pues células carentes de Sec3 (componente del exocisto) muestran un fenotipo similar al del mutante $\operatorname{ccn} 1 \Delta / \Delta$, fenotipo que se suprime al delecionar CDC11 (Li et al., 2007). El exocisto es un complejo multiproteico necesario para la fusión de las vesículas de secreción con la membrana plasmática en el sitio de crecimiento polarizado (Pruyne y Bretscher, 2000a; Pruyne y Bretscher, 2000b). En S. cerevisiae, la constricción que ocurre en el plano de división es debida a la capacidad que tiene el anillo de septinas de dirigir la secreción de vesículas a ambos lados del cuello de la célula hija, lo que produce un engrosamiento de esa zona (Gladfelter et al., 2005). Aunque las levaduras de $C$. albicans también poseen estas constricciones, las hifas de este hongo carecen de ellas a los lados del septo, por lo que se ha propuesto que en los filamentos el anillo de septinas no posee la capacidad de atraer vesículas secretoras. Estas observaciones sugieren que en las células apicales de las hifas deben existir mecanismos que modifiquen selectivamente las septinas del cuello y del "cap" para que la exocitosis tenga lugar únicamente en el ápice de la hifa. Se ha propuesto que la fosforilación de Cdc11 por Gin4 y Cdc28-Ccn1 podría reducir la afinidad de Cdc11 por Sec3 en el anillo, lo que haría que el exocisto se ensamblase principalmente en el ápice de la hifa en crecimiento (González-Novo et al., 2008; Sudbery, 2007).

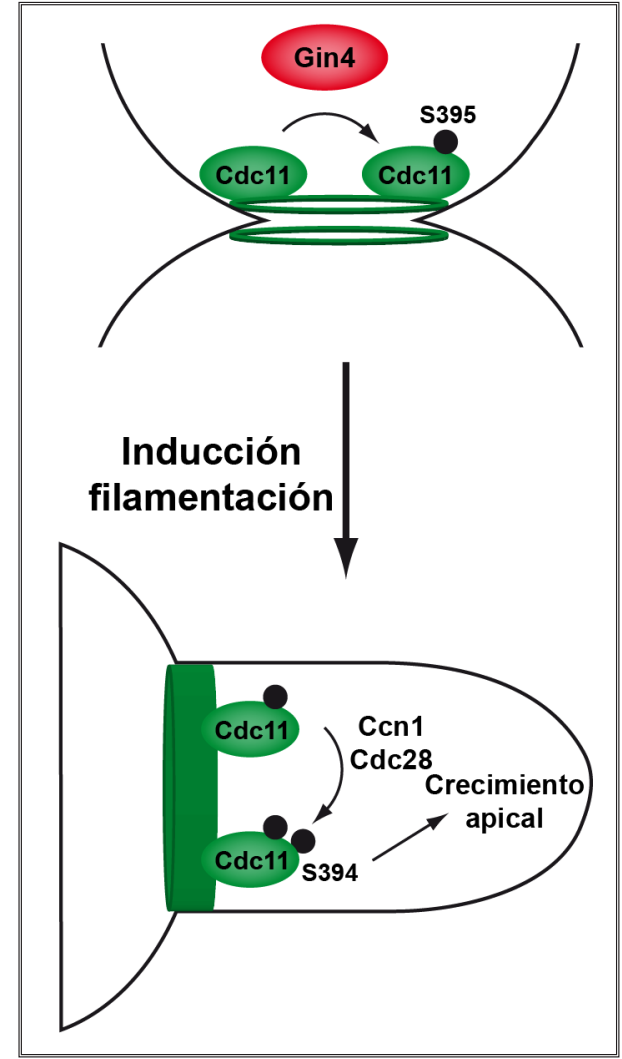

Figura 12. Las septinas son esenciales para el desarrollo de las hifas de $\boldsymbol{C}$. albicans. Durante el crecimiento en forma de levaduras, Cdc11 es fosforilado por Gin4 en la serina 395 al final del ciclo celular previo. En la inducción de la filamentación esta fosforilación permite la subsecuente fosforilación por parte de Cdc28-Ccn1 en la serina 394, lo que permite el correcto desarrollo de las hifas después del ensamblaje del primer anillo de septinas. Tomado de González-Novo et al. (2009).

Recientemente se ha demostrado que las propias septinas son necesarias para mantener el crecimiento polarizado en las hifas (Li et al., 2012b). Mediante el uso del mutante termosensible cdc12-6, que elimina los últimos 13 aminoácidos de la proteína, se ha demostrado que el mutante es capaz de responder al suero e iniciar la formación de filamentos, pero a tiempos más largos forma cadenas de compartimentos elongados sin anillos de septinas y con defectos en la formación de septos. Al mismo tiempo, estas células frecuentemente forman una segunda hifa en las proximidades de la primera, un fenotipo que no se observa en la cepa silvestre y además, son incapaces de formar la banda basal de septinas.

\subsubsection{Las septinas y la regulación de la separación celular.}

El ciclo de división celular en levaduras llega a su fin cuando los dos citoplasmas de las células resultantes se separan mediante la síntesis de una barrera física denominada septo. Ésta es una estructura muy similar en C. albicans y S. cerevisiae, presentándose en ambos casos como una estructura trilaminar. La capa central se denomina septo primario y está compuesta principalmente por quitina, sintetizada por la quitín sintasa II (Chs2), mientras que a ambos lados se encuentran los llamados septos secundarios, cuya composición química es similar al resto de la pared, compuestos principalmente de $\beta$-1,3-glucano y $\beta$-1,6-glucano (Klis et al., 2001). El último paso del ciclo celular es la separación física de las dos células por hidrólisis del septo primario. En S. cerevisiae la separación ocurre cuando el septo primario es degradado por enzimas como la quitinasa codificada por CTS1 y la endoglucanasa codificada por ENG1/DSE4, permitiendo la separación de las células madre e hija (Baladrón et 
al., 2002; Kuranda y Robbins, 1987). La expresión de estos genes es específica de la célula hija y está regulada por el factor de transcripción Ace2, el cual se acumula de forma asimétrica en el núcleo de la célula hija por acción de la quinasa Cbk1 y su subunidad reguladora Mob2 (Colman-Lerner et al., 2001). La expresión de este complejo es dependiente de la activación de la ruta de salida de mitosis (ruta MEN, del inglés "Mitotic Exit Network"), mediante liberación del núcleo de la fosfatasa Cdc14 (Brace et al., 2011). En el apartado 1.6 se describirá con más detalle la regulación de la separación celular por la ruta RAM ("Regulation of Ace2 and Morphogenesis").

En C. albicans, la separación física de las dos células durante el crecimiento en forma de levadura también depende de enzimas hidrolíticas como la endoglucanasa Eng1 y las quitinasas Cht1, Cht2 y Cht3 (Dünkler et al., 2005; Esteban et al., 2005; McCreath et al., 1995; McCreath et al., 1996), y el proceso está regulado por el factor de transcripción Ace2 (Kelly et al., 2004). En este proceso también participa la fosfatasa Cdc14, ya que el fenotipo típico de los mutantes $c d c 14 \Delta / \Delta$ es que forman de grupos de células sin separar, similares a los del mutante ace $2 \Delta / \Delta$ (Clemente-Blanco et al., 2006) (Figura 13).

Una diferencia crucial entre el crecimiento en forma de levaduras e hifas es que mientras que en las primeras la separación celular ocurre inmediatamente después de la citoquinesis permitiendo que la célula madre e hija se conviertan en entidades independientes, en las hifas la separación de los compartimentos está inhibida, permitiendo de esta manera que se formen las estructuras filamentosas típicas del crecimiento hifal de $C$. albicans. Trabajos de los últimos años están permitiendo conocer los detalles moleculares de la inhibición de la separación celular en las hifas. Como se comentó en el apartado 1.5.4, la inducción del crecimiento filamentoso trae consigo modificaciones importantes en la dinámica del anillo de septinas. En este estado morfológico, el anillo de septinas se convierte al denominado estado específico de hifas (HSS) que se caracteriza por la existencia de un núcleo estable de septinas (Cdc3, Cdc12 y Sep7) y una alta tasa de intercambio de Cdc10 entre el anillo y el citoplasma (González-Novo et al., 2008). Se ha propuesto que el núcleo formado por Cdc3, Cdc12 y Sep7 podría

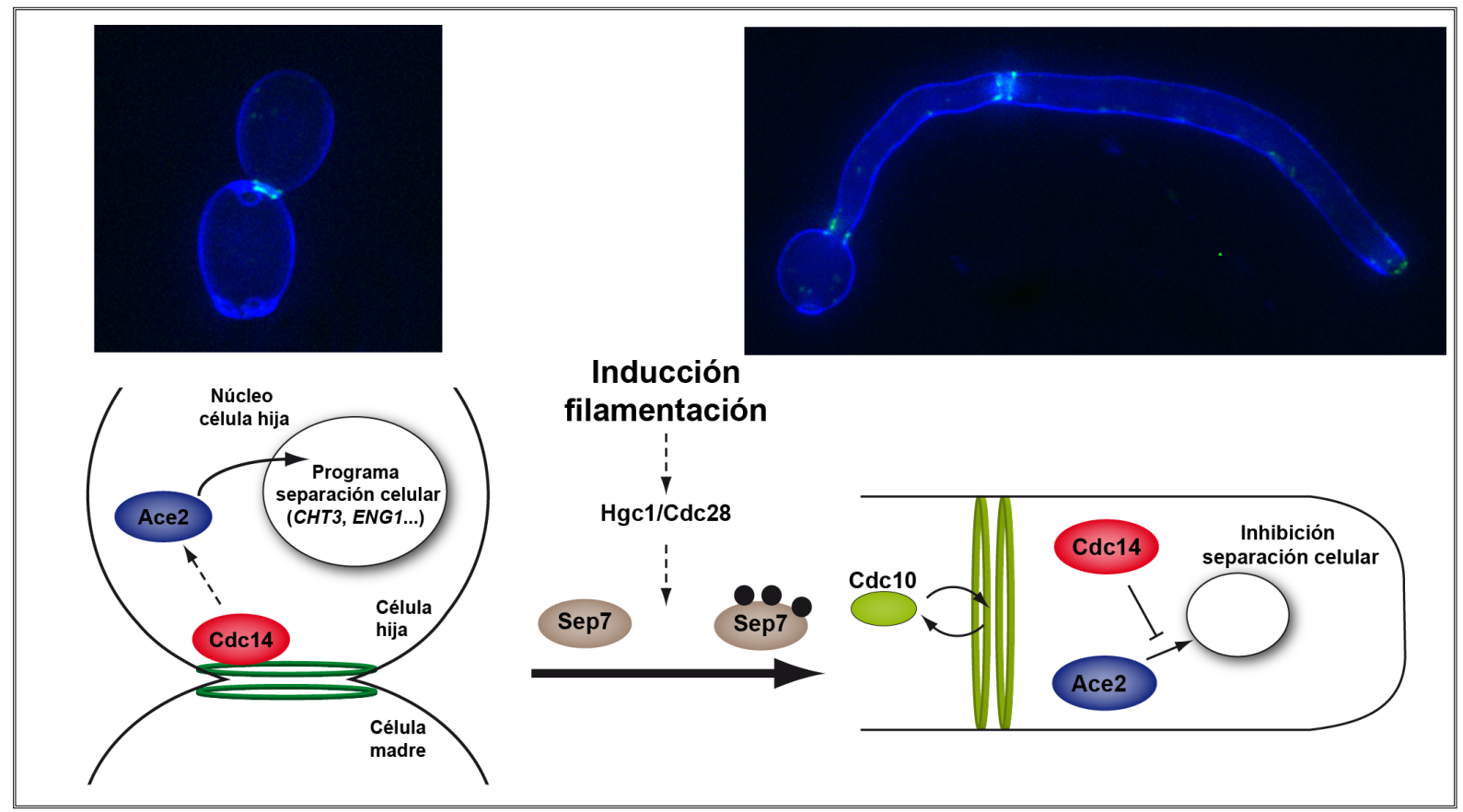

Figura 13. Regulación de la separación celular en $\boldsymbol{C}$. albicans. En levaduras las septinas sirven como andamio para la llegada de Cdc14 al plano de división, lo que activa la maquinaria de separación celular dependiente de Ace2. Con la inducción de la filamentación, las septinas cambian su dinámica al estado específico de hifas el cual se caracteriza por el alto intercambio de Cdc10 entre el citoplasma y el anillo. Esta dinámica impide que Cdc14 se transloque al septo de la hifa con lo que el programa de separación celular permanece inhibido. Este proceso es dependiente de Sep7 y de Hgc1. Modificado de González-Novo et al. (2009). 
ser suficiente para garantizar la estabilidad del anillo de septinas, mientras que el incremento en la dinámica de Cdc10 podría alterar las propiedades de andamiaje del anillo de septinas (González-Novo et al., 2009). Se ha demostrado que la conversión del anillo al estado específico de hifas depende de Sep7, ya que en un mutante $\operatorname{sep} 7 \Delta / \Delta$ los anillos de las hifas presentan una dinámica similar a la de levaduras (ausencia de intercambio de Cdc10 con el citoplasma) y de la fosforilación de Sep7 mediada por la ciclina Hgc1 (González-Novo et al., 2008).

Otro fenotipo que presentan los mutantes $\operatorname{sep} 7 \Delta / \Delta$ durante el crecimiento en forma de hifas es que activan la separación celular, de tal manera que los distintos compartimentos de la hifa se independizan en lugar de permanecer unidos, lo que indica que existe una correlación directa entre el cambio en la dinámica del anillo de septinas y la inhibición de la separación. En este proceso también está implicada la fosfatasa Cdc14, que en levaduras se localiza durante la citoquinesis en la región del septo, mientras que en hifas se mantiene excluida de él por acción del complejo Cdc28-Hgc1 y por el cambio en la dinámica del anillo de septinas (Clemente-Blanco et al., 2006; González-Novo et al., 2008). Así, se ha comprobado que en el mutante sep7 $\Delta / \Delta$ la fosfatasa Cdc14 se localiza en el septo de las hifas y esto es suficiente para activar la separación, ya que en el doble mutante $\operatorname{sep} 7 \Delta / \Delta c d c 14 \Delta / \Delta$ los compartimentos de las hifas permanecen unidos a pesar de que la dinámica del anillo de septinas es similar a la del mutante $\operatorname{sep} 7 \Delta / \Delta$. Por tanto, la modificación de la dinámica del anillo en hifas altera sus propiedades como andamio molecular, inhibiendo la asociación de determinados factores reguladores a la zona del septo. Una vez en el anillo de septinas, Cdc14 podría defosforilar a las proteínas que controlan la separación celular, como el complejo Cbk1-Mob2, que tanto en S. cerevisiae como en C. albicans se localiza en la región del septo y es necesario para la acumulación de Ace2 en el núcleo de la célula hija (Gutiérrez-Escribano et al., 2011; McNemar y Fonzi, 2002; Nelson et al., 2003).

\subsection{LA RUTA RAM}

La ruta de regulación de Ace2 y morfogénesis (conocida como ruta RAM por su nombre en inglés "Regulation of Ace 2 and Morphogenesis") es una ruta de señalización mediada por quinasas conservada en eucariotas, desde levaduras hasta humanos, la cual ha sido ampliamente estudiada en S. cerevisiae donde regula procesos como la separación celular y el crecimiento polarizado (revisado en Saputo, 2012; Weiss et al., 2002). Esta ruta es homóloga de la ruta Hippo de células eucariotas superiores, en las que regula el crecimiento tisular y controla otra serie de procesos como la determinación del destino celular, mitosis o pluripotencia (Hergovich et al., 2006; Hergovich et al., 2008). Esta Introducción se centrará fundamentalmente en la función de la ruta RAM en hongos y levaduras. Para más información sobre esta ruta en eucariotas superiores, consultar algunas revisiones recientes (Harvey y Hariharan, 2012; Hergovich et al., 2006; Kyriakis y Avruch, 2012; Ramos y Camargo, 2012).

La estructura de estas rutas es similar en todos los organismos en los que están presentes, existiendo una proteín quinasa del grupo de las quinasas de centro germinal o GCK (la quinasa "Mst/Hippo") que controla directamente la actividad de otra quinasa del grupo AGC (la quinasa "Ndr/LATS") que se encuentra unida a una subunidad co-activadora de tipo “Mob" (Edgar, 2006; Hergovich, 2011; Hergovich, 2012; Varelas et al., 2010). Las quinasas $\mathrm{Ndr} /$ LATS son el componente final de la ruta y controlan polarización celular, expresión génica y morfogénesis. Cuando estas rutas se activan, la quinasa Mst/Hippo fosforila a las quinasas Ndr/LATS en un motivo hidrofóbico próximo al extremo C-terminal (denominado HM) que está presente en todas las quinasas del grupo AGC. Esta fosforilación aumenta su actividad y al mismo tiempo es necesaria para la interacción con sus sustratos in vivo (Biondi et al., 2002; Sarbassov et al., 2005; Yang et al., 2002), aunque no está claro que las quinasas Ndr/LATS funcionen de manera similar. Las quinasas Ndr/LATS contienen un sitio de fosforilación en un lazo regulatorio de 
activación que se modifica de forma intramolecular para su activación (Bichsel et al., 2004; Jansen et al., 2006).

Existen dos tipos de rutas Mst/Hippo que se conservan en los organismos eucariotas y se mantienen como rutas de señalización independientes. En uno de ellos, el efector final de la ruta es una quinasa LATS que se asocia a un co-activador de tipo Mob1, mientras que el otro tipo está compuesto por una quinasa Ndr unida al co-activador Mob2. La ruta RAM es una ruta de tipo Ndr, mientras que la ruta MEN de S. cerevisiae es una ruta de tipo LATS, y desempeñan funciones distintas en las células. De forma similar, las rutas de células eucariotas superiores tienen distintas funciones: la ruta "salvador/warts/hippo" es una ruta tipo LATS que frena el crecimiento celular y promueve apoptosis (Harvey y Tapon, 2007; Pan, 2010; Zhao et al., 2011), mientras que la ruta "furry/tricornered/hippo" de tipo Ndr activa la división celular y controla la polaridad celular (Cornils et al., 2011; Emoto, 2011; Staley y Irvine, 2012).

En levaduras, la ruta RAM controla fundamentalmente dos procesos celulares, el crecimiento polarizado y la separación celular, por lo que mutantes carentes de cualquiera de los componentes de esta ruta presentan dos fenotipos principales: defectos en separación celular lo que genera grupos de células, e incapacidad de mantener el crecimiento polarizado, por lo que las células son redondeadas. El primero de estos fenotipos es debido al papel que Cbk1/Mob2 desempeñan en la regulación del factor de transcripción Ace2, que regula a los genes necesarios para degradar el septo (Bidlingmaier et al., 2001; Colman-Lerner et al., 2001). En cuanto al segundo fenotipo, aunque el papel de la ruta RAM en el crecimiento polarizado no ha sido bien caracterizado, se sabe que Cbk1 interviene en la regulación de procesos de secreción dependientes del aparato de Golgi y de las proteínas Sec2 y Sec4, implicadas en exocitosis (Kurischko et al., 2008).

\subsubsection{La ruta RAM en S. cerevisiae.}

En S. cerevisiae, la ruta RAM es esencial para la viabilidad de las células y está compuesta por seis proteínas que se asocian en al menos dos módulos diferentes (Bidlingmaier et al., 2001; Nelson et al., 2003; Racki et al., 2000; Weiss et al., 2002; revisado en Weiss, 2012) (Fig. 14). Las células carentes de cualquiera de estos componentes presentan fenotipos idénticos, y la pérdida de múltiples componentes no aumenta el fenotipo (Bidlingmaier et al., 2001; Nelson et al., 2003). El efector final de la ruta es el módulo formado por la Ndr quinasa Cbk1, que funciona asociada al co-activador Mob2 (Weiss et al., 2002). Cbk1 está regulada por la proteín quinasa de tipo Mst/hippo Kic1, que se asocia con la subunidad activadora Hym1 (Brace et al., 2011; Nelson et al., 2003). La proteína Tao3 es crítica para la interacción de estos dos módulos, funcionando como andamiaje de ambos complejos, aunque su papel no está bien caracterizado (Du y Novick, 2002; Jorgensen et al., 2002; Nelson et al., 2003). Adicionalmente, la proteína Sog2 es importante para la función de la ruta RAM. Sog2 es una proteína rica en leucinas y parece interaccionar directamente con el complejo Kic1-Hym1 (Nelson et al., 2003). Todos los componentes, excepto Sog2, están conservados, existiendo parálogos desde hongos hasta metazoos (Cornils et al., 2011; Emoto, 2011; Hergovich, 2011; Hergovich et al., 2006; Maerz y Seiler, 2010).

El módulo Cbk1-Mob2: Cbk1 y Mob2 están presentes durante todo el ciclo celular, se asocian de forma constitutiva y colocalizan en todo momento (Colman-Lerner et al., 2001; Weiss et al., 2002). La actividad de Cbk1 fluctúa de forma modesta durante el ciclo celular, con picos durante la formación de la yema y separación celular (Weiss et al., 2002). La localización de Cbk1 y Mob2 es consistente con su función dual en el control de la morfogénesis y separación celular. Se concentran en el cuello entre las células madre e hija en células con yemas grandes en telofase antes de la contracción del anillo de actomiosina y localizan de forma dispersa en el córtex de la célula hija (Bidlingmaier et al., 2001; Colman-Lerner et al., 2001; Racki et al., 2000; Weiss et al., 2002). Las 
dos proteínas dependen una de la otra para su correcta localización en el córtex, pero son independientes del resto de los componentes de la ruta RAM (Nelson et al., 2003; Weiss et al., 2002). También se localizan en el núcleo de la célula hija durante la transición M/G1 de forma dependiente de Ace2, lo que sugiere que entran en el núcleo formando un complejo ternario (Colman-Lerner et al., 2001; Weiss et al., 2002).

Cbk1 presenta un sitio consenso de fosforilación complejo, lo que ha facilitado la detección de sus posibles dianas "in silico". Cbk1 fosforila Ser o Thr presentes en IOS motivo H-X-X-R/K-X-S/ o H-X-R/K-X-X-S/T (Mazanka et al., 2008), similar al descrito para la familia de proteín quinasas LATS/warts de la ruta yorkie/YAP/TAZ (Shcheprova et al., 2008; Wang, 2009).

Mob2 es un miembro de la familia de proteínas Mob, que funcionan en complejos con las proteín quinasas Ndr/LATS en todos los eucariotas (Hergovich, 2011). La asociación de Mob2 con Cbk1 es crítica para la actividad quinasa, lo que indica que actúa como un co-activador (Weiss et al., 2002). Al mismo tiempo, la unión de Mob2 estabiliza a Cbk1 “in vivo” (Nelson et al., 2003; Weiss et al., 2002).

El módulo Kic1-Hym1: Kic1 es una quinasa relacionada con Mst/hippo con un dominio catalítico similar al de Cdc15 (Sullivan et al., 1998). Kic1 fue identificado inicialmente como una proteína que interaccionaba con Cdc31, una proteína relacionada con la calmodulina que es esencial para la duplicación del cuerpo polar del huso. Kic1 se asocia con Hym1, que está relacionada con las proteínas MO25 de metazoos (Bidlingmaier et al., 2001; Jorgensen et al., 2002; Nelson et al., 2003; Sullivan et al., 1998). Similar al módulo Cbk1/Mob2, Kic1 y Hym1 se localizan en los sitios de crecimiento y remodelación de la pared celular, incluyendo el córtex de la célula hija, la proyección de conjugación y el cuello, siendo la localización de Hym1 dependiente de Kic1 (Bidlingmaier et al., 2001; Nelson et al., 2003).

Las proteínas Tao3 y Sog2: Tao3/Pag1 es una proteína grande (350 kDa) esencial para la función de la ruta RAM (Du y Novick, 2002; Jorgensen et al., 2002; Nelson et al., 2003). Interacciona físicamente con Kic1 y Cbk1, por lo que puede ser un andamio molecular que facilita la comunicación entre los dos módulos (Chatr-Aryamontri et al., 2013; Nelson et al., 2003). Su localización es similar a la de los otros componentes de la ruta descritos anteriormente, pero no necesita de ellos para localizarse (Nelson et al., 2003). Tao3 está conservada desde levaduras a metazoos y pertenece a la familia de proteínas "furry" (Cong et al., 2001). Por su parte, Sog2 es una proteína rica en leucinas que interacciona con Kic1 y posiblemente con Tao3, localizando en el córtex celular

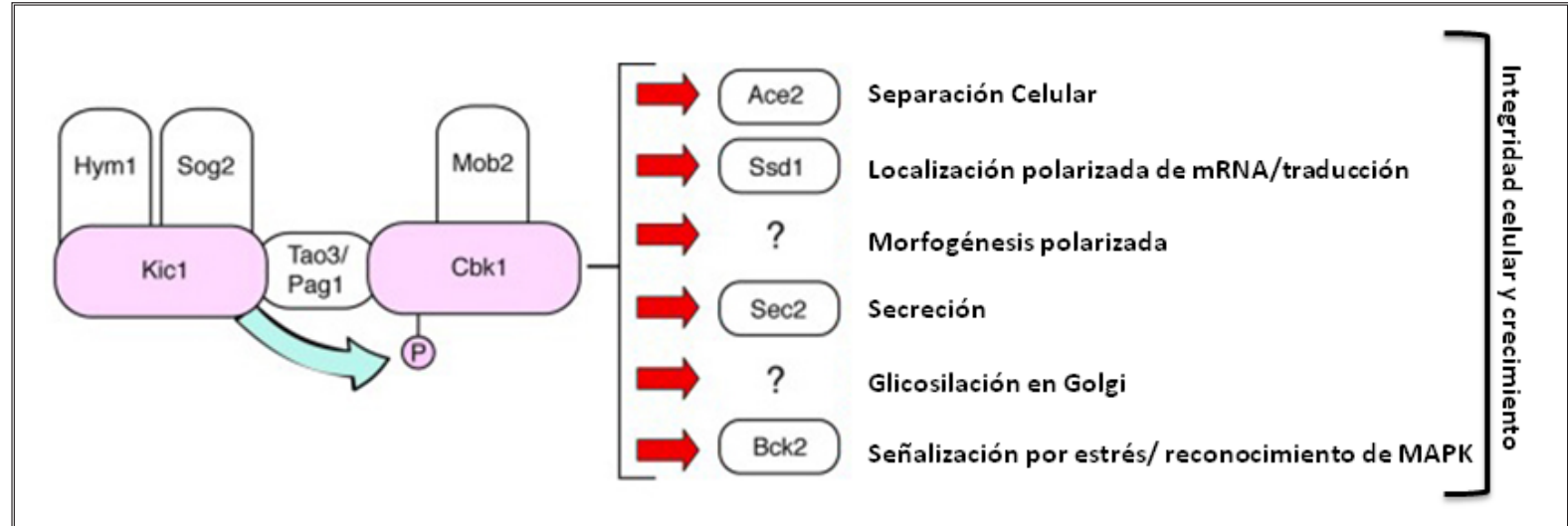

Figura 14. Ruta RAM en S. cerevisiae. Esquema de los componentes de la ruta. La flecha azul indica la fosforilación de Cbk1 por parte de Kic1, clave para su regulación. También se indican las funciones de esta ruta y los sustratos identificados que median cada una ellas. Tomado de Saputo et al. (2012). 
(Nelson et al., 2003). Es el componente menos conocido de la ruta, y no está conservado como el resto de las proteínas.

En cuanto a la función y activación de Cbk1, varios estudios han demostrado que son dependientes del resto de los otros componentes de la ruta, así como de la fosforilación en los dos sitios conservados en las quinasas de la familia Ndr/LATS (Bourens et al., 2009; Jansen et al., 2006; Panozzo et al., 2010). Mediante el uso de anticuerpos fosfoespecíficos que reconocen la fosforilación en el motivo HM o en el lazo de activación, se ha comprobado que ambos sitios están fosforilados “in vivo" (Jansen et al., 2006). La fosforilación del motivo HM es dinámica a lo largo del ciclo celular, con picos durante la separación y el crecimiento de la yema, mientras que la fosforilación en el lazo de activación, que ocurre mediante autofosforilación, se mantiene relativamente constante (Jansen et al., 2006). Análisis genéticos indican que la fosforilación en estos dos sitios es importante para la función de Cbk1, aunque en distinta medida (Bourens et al., 2009; Jansen et al., 2006; Panozzo et al., 2010). La mutación del sitio de fosforilación en el lazo activador reduce severamente la actividad catalítica de Cbk1, aunque este alelo produce un fenotipo moderado, tanto en crecimiento polarizado como en separación (Bourens et al., 2009; Jansen et al., 2006). Por el contrario, la mutación del sitio HM a Ala elimina completamente la función de Cbk1 "in vivo", pero no la actividad quinasa "in vitro", mientras que su cambio a Glu aumenta significativamente la actividad quinasa (Brace et al., 2011). La fosforilación del sitio HM necesita de todos los componentes de la ruta RAM, pero también está reducida significativamente en los mutantes ace2 $\Delta$, lo que indica que este sustrato promueve la activación de su quinasa. No se conoce el mecanismo por el que Ace2 aumenta la fosforilación de Cbk1, aunque se piensa que podría ser porque aumenta la unión con Kic1-Hym1, porque oculta el sitio fosforilado a una fosfatasa o porque secuestra a Cbk1-Mob2 en el núcleo donde no se encuentra dicha fosfatasa.

La función mejor caracterizada de Cbk1 y la ruta RAM en S. cerevisiae es la regulación del proceso de separación celular a través de la fosforilación y regulación del factor de transcripción Ace2. Como se ha comentado anteriormente, la separación celular ocurre por destrucción del septo primario que separa ambas células. Este proceso ocurre minutos después de que ha sido sintetizado, por lo que su regulación temporal debe estar finamente ajustada con la síntesis del septo para impedir que la degradación comience demasiado pronto y se produzca la lisis celular. Al mismo tiempo también existe un control espacial, ya que ocurre desde el lado de la célula hija. El control temporal y espacial de este proceso dependen de la ruta RAM, que asegura que la destrucción del septo sea un proceso que ocurra únicamente una vez en la vida de una célula, cuando es una célula hija. Ace2 es un factor de transcripción que contiene dos dedos de Zinc de tipo $\mathrm{C} 2 \mathrm{H} 2$ cerca de su extremo C-terminal, que reconocen la secuencia GCTGG[G/T/C] (Dohrmann et al., 1992; Dohrmann et al., 1996). También contiene señales de importación (NLS) y exportación (NES) nuclear independientes, que han sido confirmadas “in vivo". La señal NLS se localiza en el extremo C-terminal detrás de los dedos de Zn, mientras que la secuencia NES está cerca del extremo amino (Jensen et al., 2000; Mazanka et al., 2008). Mediante experimentos de intercambio de dominios con el factor de transcripción Swi5, el cual es muy parecido a Ace2, se ha comprobado que existen varias regiones funcionales, y que la unión con Cbk1 tiene lugar mediante una región en el centro de la proteína (McBride et al., 1999; Sbia et al., 2008). Ace2 regula un grupo de genes que codifican las enzimas que se encargan de la degradación del septo, activando su expresión de forma precisa en el momento en que tiene lugar la separación (Lu et al., 2007; Spellman et al., 1998). Estos genes incluyen CTS1, SCW11, DSE2, DSE3, ENG1/ DSE4 y SUN4, que codifican distintas glucanasas o quitinasas encargadas de la degradación del septo (Baladrón et al., 2002; Bidlingmaier et al., 2001; Colman-Lerner et al., 2001; Di Talia et al., 2009; Dohrmann et al., 1992; O'Conallain et al., 1999; O'Conallain et al., 1998). 
Inicialmente, Ace2 se regula a nivel de transcripción, ocurriendo su expresión al comienzo de la fase $\mathrm{M}$ bajo el control del factor de transcripción Fkh2, de la familia "Forkhead" (Hollenhorst et al., 2001; Koranda et al., 2000), pero también está regulada su acumulación en el núcleo de forma precisa. Una vez que se ha sintetizado, Ace2 se mantiene en el citoplasma durante la mitosis temprana porque la actividad CDK mitótica fosforila una serie de sitios próximos a la NLS y la mantiene inactiva hasta que comienza la salida de mitosis (Dohrmann et al., 1992; O’Conallain et al., 1999) (Fig. 15). La sustitución de estos sitios de fosforilación por Ala permite la entrada de Ace2 al núcleo antes de tiempo (Brace et al., 2011; Mazanka y Weiss, 2010; O'Conallain et al., 1999; Sbia et al., 2008). De hecho, estos sitios están fosforilados "in vivo", según se ha determinado mediante ensayos de espectrometría de masas masivos (Archambault et al., 2004; Holt et al., 2009). Al final de mitosis, cuando se activa la ruta MEN de salida de mitosis, se produce una defosforilación rápida de los sitios CDK fosforilados de Ace2, de forma dependiente de la fosfatasa Cdc14 (Archambault et al., 2004; Mazanka y Weiss, 2010; Sbia et al., 2008). Esta defosforilación es necesaria, pero no suficiente, para activar la expresión de las dianas de Ace2. En células mitóticas Ace2 se distribuye de forma isotrópica en ambas células, pero está excluida del núcleo hasta el final de anafase. La proteína comienza a ser visible en el núcleo de las células madre e hija durante telofase, momento en el que se produce tanto el importe como el exporte nuclear. Unos minutos antes de la contracción del anillo de actomiosina, la distribución de Ace2 cambia y comienza a acumularse exclusivamente en el núcleo de la célula hija, donde permanece hasta que se completa la separación de las células madre e hija. Este cambio en el comportamiento de Ace2 se debe a la acción de la ruta RAM. Cbk1 regula directamente el transporte núcleo-citoplasma de Ace2 fosforilando dos sitios consenso que se encuentran al lado de la señal NES y la inactivan, permitiendo de esta manera su acumulación nuclear asimétrica (Brace et al., 2011; Mazanka y Weiss, 2010; Mazanka et al., 2008). Cbk1 también regula a Ace2 fosforilando otro sitio en el centro de la proteína (S436). Esta fosforilación no es necesaria para la localización nuclear, sino que sirve para aumentar la actividad transcripcional de Ace2 (Mazanka et al., 2008).

Por tanto, el proceso de separación está finamente regulado por varias las rutas de señalización CDK, FEAR, MEN y RAM, que actúan de forma secuencial durante mitosis y G1, controlando de forma precisa la localización y

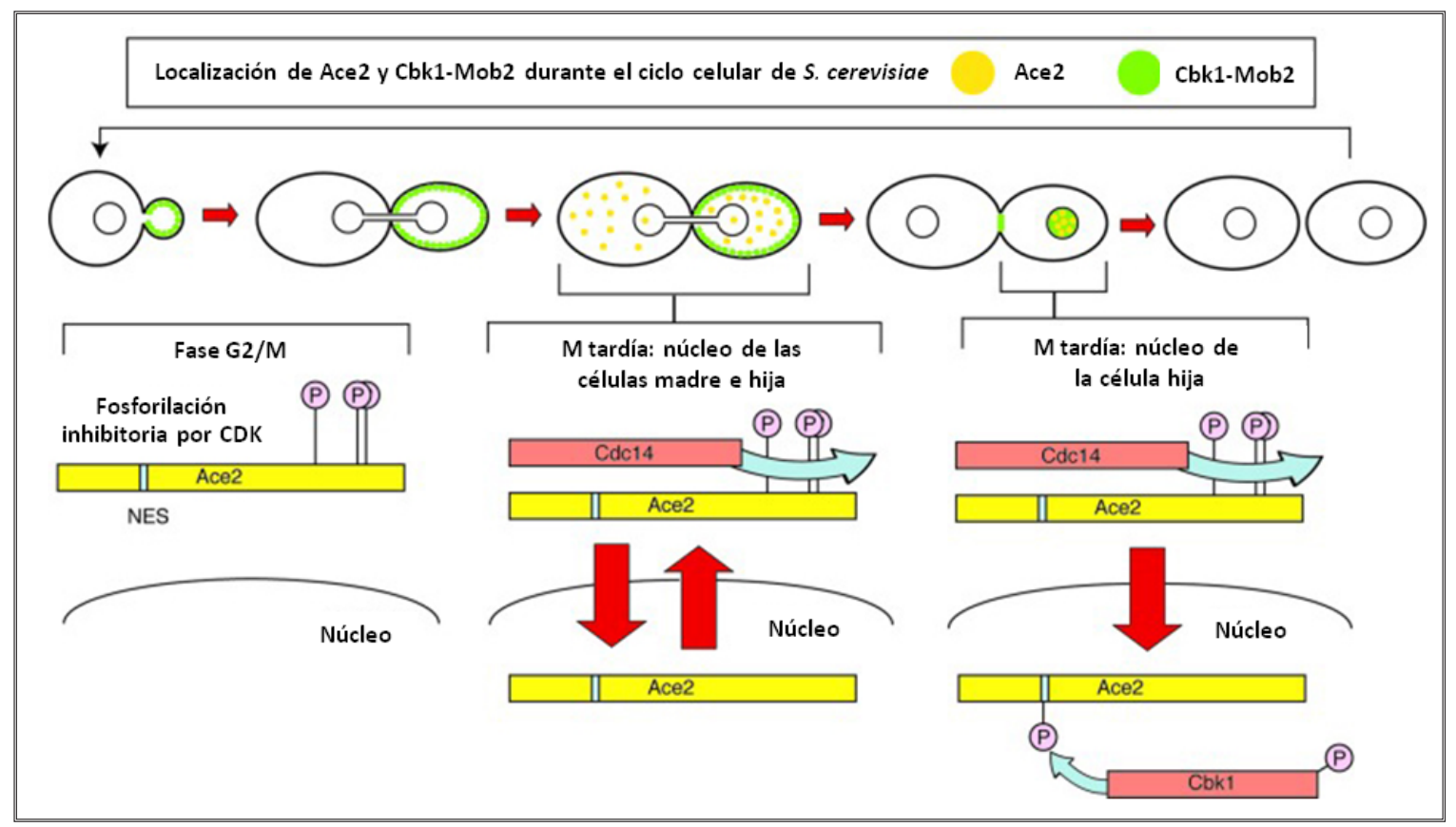

Figura 15. Esquema general de la ruta RAM en S. cerevisiae. La ruta RAM y las quinasas dependientes de ciclinas regulan la localización específica en la célula hija y la activación de Ace2. Tomado de Saputo et al. (2012). 
activación de Ace2. En este mecanismo, Cbk1 regula a Ace2 de dos maneras: permitiendo su acumulación en el núcleo de la célula hija y aumentando su actividad transcripcional. Sin embargo, un aspecto que todavía se desconoce de esta regulación es el mecanismo por el que se genera la asimetría de Ace2 y que hace que se acumule exclusivamente en el núcleo de la célula hija.

\subsubsection{La ruta RAM en C. albicans.}

La ruta RAM en C. albicans se compone de los mismos elementos descritos para S. cerevisiae, las proteínas Cbk1, Mob2, Kic1, Hym1, Pag1 y Sog2 (McNemar y Fonzi, 2002; Song et al., 2008). Aunque los datos conocidos no son tan abundantes como en $S$. cerevisiae, los fenotipos de los mutantes carentes de cualquiera de estos componentes son similares a los de $S$. cerevisiae, células en grupos incapaces de separarse y defectos en polarización, lo que indica que las funciones son similares en ambos organismos. La deleción de CBK1 inhibe la separación celular, produciendo agregados de células que no se separan por sonicación (McNemar y Fonzi, 2002) y la expresión de los genes implicados en separación (como CHT2 y CHT3) está reducida, lo que sugiere que en C. albicans Cbk1 también regula a Ace2. Además, los mutantes $c b k 1 \Delta / \Delta$ son incapaces de formar filamentos, indicando que la ruta RAM también es necesaria para el crecimiento polarizado. Consistente con esta idea, se ha comprobado también que los mutantes mob $2 \Delta / \Delta, \operatorname{kic} 1 \Delta / \Delta$, pag $1 \Delta / \Delta$, hym $1 \Delta / \Delta$ y sog $2 \Delta / \Delta$ presentan los mismos defectos que los mutantes $c b k 1 \Delta / \Delta$ y que la expresión de los genes regulados por Ace2 y de un grupo de genes específicos de hifas está reducida en el mutante $\operatorname{mob2} \Delta / \Delta$ (Song et al., 2008). Los defectos presentados por los mutantes de la ruta RAM durante la inducción de las hifas han sido relacionados con una desregulación de Nrg1 y Tup1, los cuales actúan como represores de los genes específicos de hifas o HSGs (Song et al., 2008).

Respecto al factor de transcripción Ace2, aunque en algunas especies de Candida spp. se han descrito tanto a ACE2 como a su ortólogo SWI5, en C. albicans solamente se ha identificado un gen que presenta homología tanto con SCACE2 ( $24 \%$ de identidad) como con SCSWI5 (21\% de identidad). A pesar de que las secuencias de aminoácidos de ScAce2 y CaAce2 no son muy similares, la región de los dedos de zinc se encuentra altamente conservada entre las dos proteínas (Kelly et al., 2004). También existe un cierto grado de conservación en el extremo amino, donde se localiza la secuencia NES y dos de los sitios de fosforilación por Cbk1-Mob2, lo que sugiere que los mecanismos de regulación de la localización de Ace2 podrían estar conservados en S. cerevisiae y $C$. albicans. Similar a lo que ocurre en $S$. cerevisiae, los mutantes ace $2 \Delta / \Delta$ exhiben importantes defectos de la separación celular y en la expresión del gen CHT3 (Clemente-Blanco et al., 2006; Kamran et al., 2004; Song et al., 2008). Consistente con su papel en la regulación de genes implicados en separación celular, Ace2 se localiza tanto en el núcleo de las células hijas de levaduras como en el núcleo de las hifas (Bharucha et al., 2011; Kelly et al., 2004; Wang, 2009). Mediante experimentos de expresión génica usando "microarrays", se ha comprobado que Ace2 no sólo regula la expresión de las enzimas que degradan el septo durante la separación, sino que también induce la expresión de genes que codifican para enzimas glicolíticas y reprime, de forma directa o indirecta, la de los genes implicados en respiración (Mulhern et al., 2006). Recientemente también se ha descrito que Ace2 regula la expresión basal de los genes que codifican para O-manosil transferasas (Cantero y Ernst, 2011).

Además de ser dependiente de la ruta RAM, la expresión de los genes controlados de Ace2 también está regulada por la quinasa dependiente de ciclinas Cdc28 y por la fosfatasa Cdc14 (Clemente-Blanco et al., 2006; Wang, et al., 2009). Se ha demostrado que Cdc28 fosforila al modulador transcripcional Efg1, el cual a su vez reprime la expresión de genes implicados en separación celular mediada por Ace2 durante las fases tempranas del ciclo celular y durante la transición levadura-hifa (Wang, et al., 2009). Del mismo modo, la fosfatasa Cdc14 es necesaria para la acumulación nuclear de Ace2 y por tanto también es necesaria para la expresión de las dianas 
de este factor de transcripción (Clemente-Blanco et al., 2006).

Teniendo en cuenta que la transición levadura-hifa en C. albicans está fuertemente asociada con la capacidad patógena del hongo, el estudio del papel de Ace2 en morfogénesis ha suscitado mucho interés. Gracias a ello, se ha comprobado que los mutantes ace $2 \Delta / \Delta$ forman pseudohifas en condiciones en las que no se induce la filamentación de la cepa silvestre y posee una mayor capacidad de invadir el agar, lo que podría estar relacionado con el incremento en la actividad de la ruta PKA, como una respuesta compensatoria al decaimiento de la transcripción mediada por la ruta RAM (Bharucha et al., 2011). Sin embargo, estos mutantes no presentan ningún defecto en la inducción de la filamentación, lo que indica que Ace2 no es necesario para el crecimiento polarizado, a diferencia del resto de los mutantes de la ruta RAM que son incapaces de formar hifas (ClementeBlanco et al., 2006; Kelly et al., 2004; McNemar y Fonzi, 2002; Song et al., 2008). Cuando se analizó la virulencia de los mutantes ace $2 \Delta / \Delta$ en modelos murinos de candidiasis diseminada, se comprobó que eran menos virulentos que la cepa silvestre, tanto en ratones inmunodeprimidos como en ratones neutropénicos (Kelly et al., 2004). Sin embargo, en el caso de C. glabrata o Aspergillus fumigatus, los mutantes carentes de ACE2 son hipervirulentos (Ejzykowicz et al., 2009; Kamran et al., 2004).

El complejo papel de Ace2 en la filamentación de C. albicans está resaltado por el hecho de que este factor de transcripción es necesario para la formación de hifas bajo condiciones limitantes de oxigeno (Mulhern et al., 2006). Estos autores sugieren que la filamentación bajo condiciones de carencia de oxigeno es inducida por la disminución de la respiración. Como ya se mencionó, Ace2 es necesario para la correcta expresión de genes glicolíticos y para reducir la expresión de genes de respiración celular. Consistente con estos efectos transcripcionales, los mutantes ace $2 \Delta / \Delta$ tienen aumentada la actividad respiratoria y por tanto son incapaces de filamentar en condiciones de hipoxia. Del mismo modo, estos mutantes son resistente a antimicina $B$, una droga que inhibe la función del citocromo y por tanto, la respiración. De acuerdo con esto, la antimicina B induce filamentación en cepas silvestres de $C$. albicans pero no en los mutantes ace $2 \Delta / \Delta$. En $C$. albicans, Ace2 también desempeña un papel importante en la capacidad de las células de adherirse a superficies de plástico y formar biofilms (Kelly et al., 2004), y esto se debe a que recientemente se ha descrito que Ace2 es un regulador clave de la formación de biofilm (Finkel et al., 2012).

En un "screening" genético realizado recientemente con genes y rutas de señalización que interactúan con Cbk1 durante la morfogénesis de hifas, se han identificado algunas de las dianas de la ruta PKA (Bharucha et al., 2011). Estas observaciones indican que en C. albicans las rutas PKA y RAM interactúan durante la morfogénesis. En consistencia con esta hipótesis, las cepas que contienen mutaciones en CBK1 y en TPK1 muestran defectos sintéticos en la morfogénesis. Además, los mutantes de la ruta RAM ( $c b k 1 \Delta / \Delta$ y ace $2 \Delta / \Delta)$ presentan un incremento en la expresión de EFG1 y en la actividad de la ruta PKA en comparación con la cepa silvestre, lo que a su vez se ve reflejado en el incremento en la cantidad de pseudohifas presentes. Este fenotipo también es observado en el mutante $a c e 2 \Delta / \Delta$ y se suprime mediante el uso de drogas que inhiben la ruta PKA, lo que apoya la idea de que los mutantes de la ruta RAM tienen elevados los niveles de actividad PKA (Bharucha et al., 2011).

Todos los datos expuestos sugieren que la ruta PKA podría ser una alternativa para compensar la disminución de las funciones de la ruta RAM. Una evidencia que apoya esta idea es que según los estudios de los perfiles transcripcionales Ace2 y Efg1 podrían co-regular un grupo de genes. Además, mediante microscopia de fluorescencia se ha comprobado que Efg1 está presente en el núcleo al inicio de la morfogénesis de las hifas, pero está casi ausente en los núcleo de las hifas ya formadas, mientras que Ace2 se localiza principalmente en 
el núcleo de la célula hija y su expresión se incrementa más tarde durante desarrollo de las hifas (Bharucha et al., 2011; Wang, 2009). Todas estas observaciones sugieren un modelo en el cual Efg1 y Ace2 co-regulan un grupo común de genes en diferentes estados del crecimiento filamentoso, en el que Efg1 funciona al inicio de la formación del tubo germinal y Ace2 cuando el núcleo se localiza en el nuevo compartimento hifal. Otra evidencia que apoya esta idea es el hecho de que Efg1 puede actuar como represor o activador transcripcional, suprimiendo la expresión de los genes de separación celular regulados por Ace2 en las fases tempranas de la morfogénesis (entre las 0 y 2 horas post-inducción).

También se ha demostrado que la represión de las dianas de Ace2 por parte de Efg1, tales como CTS1, es dependiente de su fosforilación en T179 por la quinasa Cdc28. El hecho de que la fosfatasa Cdc14 también sea necesaria para la expresión de los genes de separación celular regulados por Ace2 (Clemente-Blanco et al., 2006) apunta a que la actividad CDK desempeña un papel importante en la modulación transcripcional entre Efg1 y Ace2.

De hecho, la quinasa Cdc28 parece desempeñar un papel relevante en la regulación y coordinación de estas rutas, ya que recientemente se ha demostrado que Cdc28 regula directamente a la ruta RAM a través de la fosforilación directa de Mob2 en cuatro sitios consenso en las fases tempranas del desarrollo hifal. Un mutante fosfodeficiente mob2-4A presenta defectos en el crecimiento polarizado y el desarrollo de las hifas, aunque la expresión de los genes CHT3 y SCW11 está aumentada en relación con la cepa silvestre (Gutiérrez-Escribano et al., 2011). Estos resultados sugieren que la fosforilación de los 4 sitios consenso de Mob2 por CDK regula de forma negativa la capacidad de Cbk1 de activar la transcripción dependiente de Ace2 al inicio de la morfogénesis hifal. Por tanto, en C. albicans la quinasa Cdc28 regula negativamente la actividad de Ace2 a través tanto de Efg1 como de Mob2.

En base a estos resultados, se ha sugerido un posible modelo para explicar la interacción entre Cdc28, la ruta PKA y la ruta RAM (Fig. 16) (Saputo, et al., 2012). En este modelo, la fosforilación de Efg1 y Mob2 por la quinasa Cdc28 impide la expresión inapropiada de las dianas de Ace 2 en las etapas iniciales de la morfogénesis de las hifas. En etapas posteriores del desarrollo, Ace2 comienza a acumularse en el núcleo de la hifa al tiempo que la cantidad de Efg1 decrece y se produce la defosforilación de Mob2. Todo esto conduce a la eliminación de la represión de la transcripción mediada por Ace2. Ya que la fosfatasa Cdc14 también es necesaria para la expresión de las dianas de Ace2, es posible que participe en esta regulación mediante la defosforilación de Efg1 y/o Mob2. Por tanto, parecen existir múltiples niveles de regulación que controlan la interconexión entre Efg1 y Ace2 durante la morfogénesis y de ahí la importancia de las investigaciones que ayuden a entender esta interacción.

Además de la regulación de la separación celular, estudios recientes han puesto de manifiesto que el complejo Cbk1-Mob2

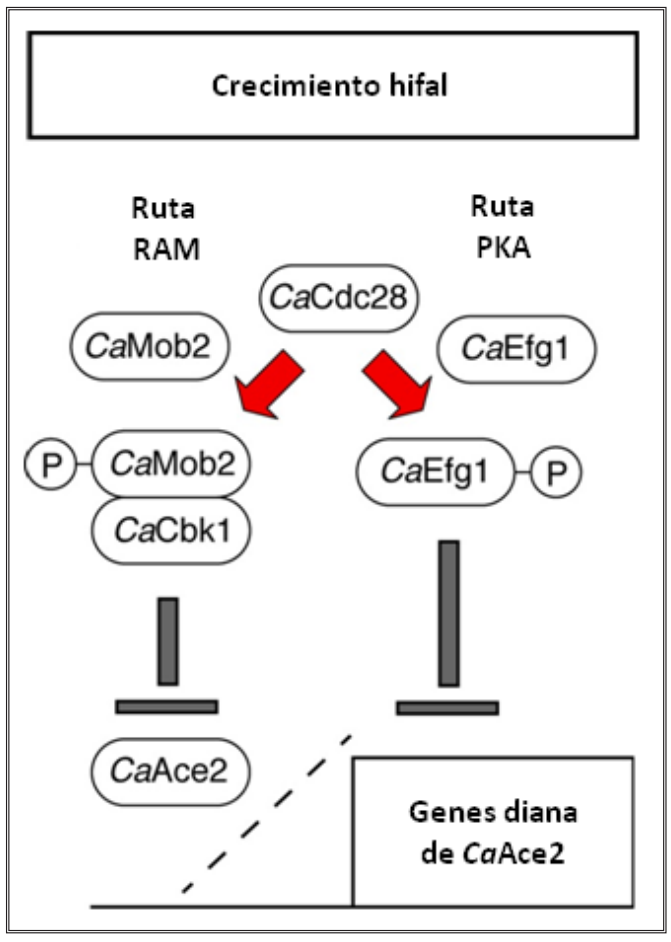

Figura 16. Modelo de la regulación mediada por $\mathrm{Cdc28}$ de los componentes de las ruta RAM y PKA durante la morfogénesis de hifas. Tomado de Saputo et al. (2012). 
desempeña otras funciones esenciales en la regulación del crecimiento polarizado y control transcripcional. Gutiérrez-Escribano y colaboradores han demostrado que en C. albicans la fosforilación de los cuatro sitios de Mob2 por parte de Cdc28 es necesaria para el mantenimiento de la organización distintiva de componentes del polarisoma durante el crecimiento hifal (Gutiérrez-Escribano et al., 2011). En las hifas del mutante mob2-4A las proteínas Spa2 y Kel1 se encuentran desorganizadas, y se ha propuesto que Spa2 podría ser una diana del complejo Cbk1-Mob2, ya que contiene 4 posibles sitios de fosforilación de esta quinasa agrupados en la región central de la proteína (S121, S143, S153 and S163), y al menos uno de ellos se encuentra fosforilado "in vivo" (Beltrao et al., 2009), lo que sugiere que Spa2 podría ser un sustrato directo del complejo Cbk1-Mob2.

También se ha demostrado que Cbk1-Mob2 regulan el desarrollo de biofilms a través de la fosforilación del factor de transcripción Bcr1. El desarrollo de un biofilm necesita de la activación transcripcional de un conjunto de genes específicos que depende de los factores de transcripción Tec1, Bcr1y Zap1 (Ganguly y Mitchell, 2011; Nobile y Mitchell, 2005; Nobile et al., 2006; Nobile et al., 2009). Bcr1 regula un conjunto de genes que codifican proteínas de pared celular, como las aglutininas Als1 y Als3 y la proteína especifica de hifas Hwp1 (Nobile y Mitchell, 2006; Nobile et al., 2009). Bcr1 contiene dos posibles sitios de fosforilación por Cbk1-Mob2, cuya mutación a Ala reduce sustancialmente la capacidad de formar biofilms y la virulencia en un modelo murino de candidiasis diseminada, mientras que la sustitución por Glu recupera parcialmente los defectos de formación de biofilms del mutante $c b k 1 \Delta / \Delta$ (Gutiérrez-Escribano et al., 2012). Estos resultados indican que la ruta RAM controla el desarrollo de biofilms en C. albicans a través de la fosforilación del factor de transcripción Bcr1 por la quinasa Cbk1. 

2.0bjetivos 



\section{OBJETIVOS}

El trabajo descrito en la presente Memoria se enmarca dentro de un proyecto más amplio que tiene como objetivo el estudiar los procesos que regulan temporal y espacialmente la separación celular en hongos y levaduras.

El presente proyecto tiene como objetivo general el estudio de la regulación de la separación celular durante el crecimiento filamentoso de Candida albicans y la implicación del factor de transcripción Ace2 en este proceso. Para ello se plantearon los siguientes objetivos específicos:

1. Realizar un análisis estructural del gen ACE2 y de sus transcritos, mediante técnicas como RT-PCR, qRT-PCR y RACE.

2. Analizar y determinar si existen dos formas diferentes de la proteína Ace2 en los distintos estados morfológicos, así como sus características bioquímicas y su localización.

3. Estudiar la función biológica y hacer una aproximación a la función molecular de las proteínas codificadas por el gen ACE2 de C. albicans. 

3.Resultados 



\subsection{ACE2 SE TRADUCE EN DOS ISOFORMAS}

Los datos obtenidos recientemente del proyecto de secuenciación del genoma humano han demostrado que está compuesto por un número relativamente bajo de genes (cerca de 35.000), comparado con organismos más simples como Drosophila melanogaster (13.601 genes) o Caenorhabditis elegans (18.424 genes). Esto resalta la importancia de los mecanismos que generan diversidad proteica por vías alternativas de expresión génica, las cuales le permiten a un organismo incrementar su nivel de complejidad. De hecho, los 35.000 genes del genoma humano expresan más de 100.000 proteínas gracias a la existencia de mecanismos que permiten generar diversos polipéptidos a partir de un gen, con una gran diversidad funcional (Touriol et al., 2003).

En este Capítulo, se mostrarán los resultados que evidencian que a partir del gen ACE2 se producen dos proteínas diferentes, una que funciona como factor de transcripción que regula la expresión de genes de separación celular y respiración, y otra que estaría unida a membranas y funcionaría como parte de la maquinaria que regula la dinámica del anillo de septinas durante el crecimiento hifal de C. albicans, uno de los mecanismos adaptativos del hongo.

3.1.1 Ace2 participa en la regulación de la dinámica del anillo de septinas durante el crecimiento hifal de $C$. albicans.

Como se ha comentado en la Introducción, resultados previos del laboratorio indicaban que la inhibición de la separación celular en hifas depende de la modificación de la dinámica del anillo de septinas, el cual es convertido a una forma específica de hifas (González-Novo et al., 2008). Este estado se caracteriza porque dos de las septinas, Cdc10 y Cdc11, presentan un alto intercambio entre el citoplasma y el anillo, mientras que las otras tres septinas (Cdc3, Cdc12 y Sep7) se mantienen estables. El cambio al estado específico de hifas y la inhibición de la separación celular son dependientes de Sep7, pues las hifas del mutante $\operatorname{sep} 7 \Delta / \Delta$ poseen una dinámica similar a la de levaduras y al mismo tiempo activan la maquinaría de separación celular. Estas observaciones sugieren que existe una correlación directa entre la dinámica del anillo de septinas y la inhibición de la separación celular. Dado que Ace2 es el factor de transcripción que activa la expresión de los genes implicados en la disolución del septo, "a priori" cabía suponer que el cambio en la dinámica de los anillos de septinas que ocurre en hifas fuera necesario para inhibir la actividad de Ace2, impidiendo de esta manera que los compartimentos hifales se separen. Para comprobar si realmente Ace2 funcionaba por debajo de las septinas en el proceso de inhibición de la separación celular en hifas, se construyó un mutante ace $2 \Delta / \Delta$ para analizar la estructura y dinámica de los anillos de septinas en hifas. En él, las regiones codificantes completas de los dos alelos del gen fueron reemplazadas por la secuencia de los genes ARG4 o HIS1. Todas las cepas construidas durante este trabajo fueron comprobadas por PCR y/o secuenciación. Como se ha descrito previamente, este mutante no poseía ningún defecto en la tasa de crecimiento ni en medio mínimo YNB ni en medio rico YEPD comparado con la cepa silvestre (Kelly et al., 2004), aunque se observaron defectos en la morfología de las colonias cuando las cepas se crecían en placas debido al defecto en separación

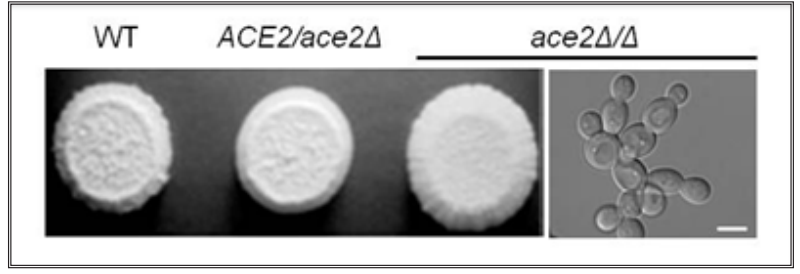

Figura 17. Las colonias del mutante $a c e 2 \Delta / \Delta$ son diferentes a las de la cepa silvestre. C. albicans creciendo en placas de medio YEPD a $30^{\circ} \mathrm{C}$ (Modificado de Kelly et al., 2004) y morfología de las células del mutante al microscopio. típico de este mutante (Fig. 17).

También se analizó el desarrollo del hongo durante el crecimiento hifal mediante técnicas de microscopía óptica y de fluorescencia. Este análisis se realizó induciendo la filamentación de la cepa silvestre BWP17 y del mutante ace $2 \Delta / \Delta$, y su posterior tinción 


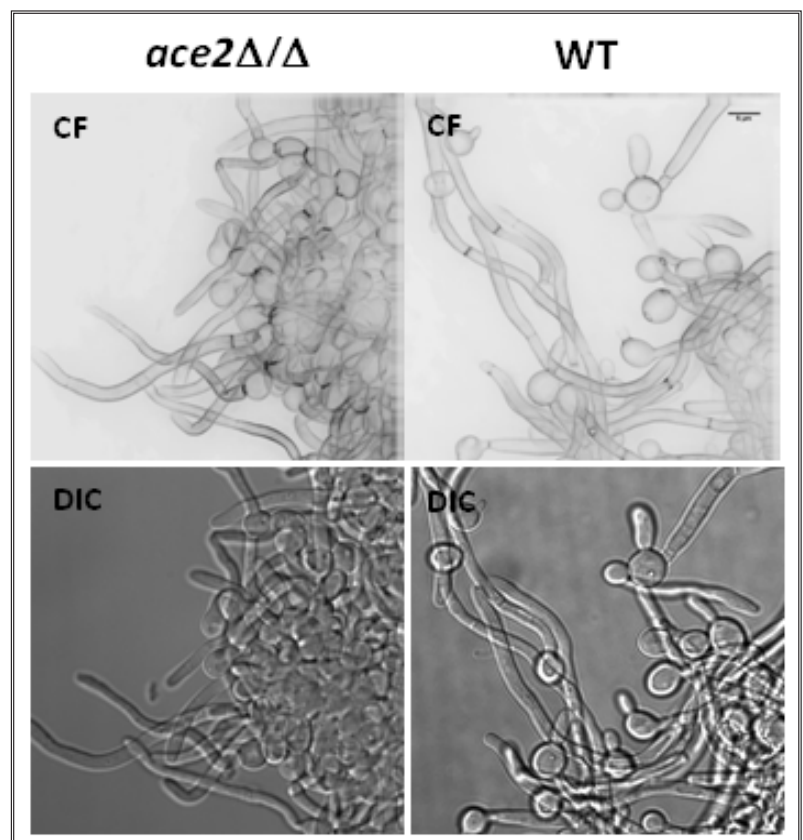

Figura 18. Morfología de las hifas de la cepa silvestre BWP17 y del mutante ace $2 \Delta / \Delta$ (OL1451). Imágenes de microscopía de contraste interferencial (DIC) y de la tinción con calcofluor (CF) de filamentos de $C$. albicans tras tres horas de inducción. Barra de escala, $5 \mu \mathrm{m}$.

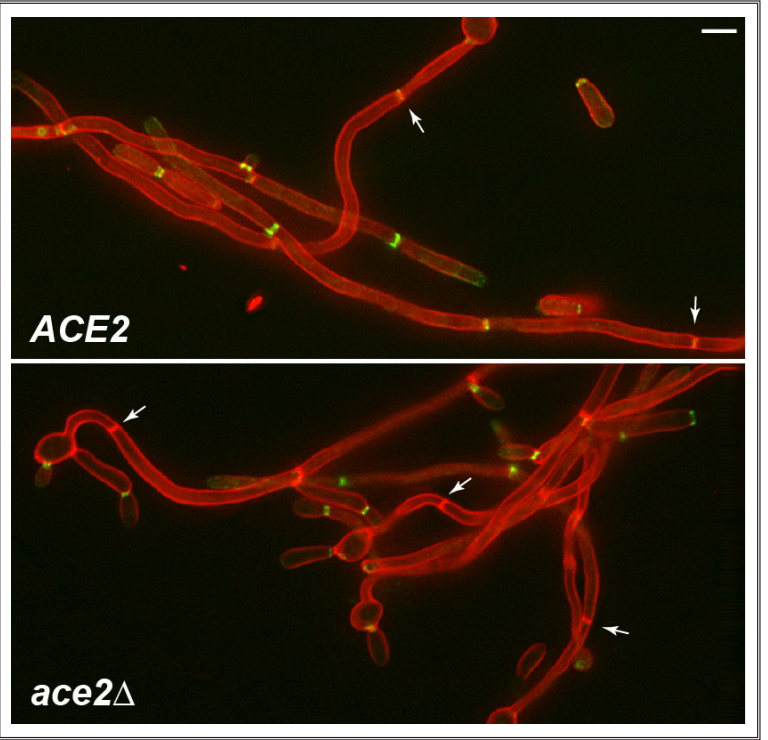

Figura 19. Los anillos de septinas son menos persistentes en el mutante $a c e 2 \Delta / \Delta$. Imágenes de fluorescencia de las cepas $A C E 2$ CDC10-GFP (OL1430) y ace $2 \Delta / \triangle$ CDC10-GFP (OL1444) tras $4,5 \mathrm{~h}$ de inducción de la filamentación. Las cepas fueron teñidas con calcoflúor antes de su visualización por microscopía de fluorescencia. Las imágenes son la proyección máxima de 10 planos adquiridos cada 0,4 $\mu \mathrm{m}$ y muestran la fluorescencia de Cdc10-GFP (verde) y la tinción de calcoflúor (rojo). Barra de escala, $5 \mu \mathrm{m}$.

con calcoflúor. A pesar de que las células de levadura del mutante ace $2 \Delta / \Delta$ se mantienen unidas formando grupos por su defecto en separación, son capaces de responder a la inducción de la filamentación y formar hifas que aparentemente son similares a las de la cepa silvestre (Fig. 18).

Para analizar con más detalle la morfología de las hifas del mutante ace $2 \Delta / \Delta$, se utilizó una cepa en la que la septina Cdc10 (la cual presenta una dinámica de intercambio en hifas) estaba etiquetada con la proteína fluorescente verde (GFP) y se comparó con la cepa silvestre en la que también se había marcado Cdc10. El primer fenotipo analizado fue la persistencia de los anillos de septinas en hifas con dos o tres septos. Para ello, la cepa silvestre y el mutante nulo se incubaron en condiciones de inducción de la filamentación durante 4,5 horas y se hicieron fotografías en el microscopio de fluorescencia con el fin de comparar la persistencia de los anillos de $C d c 10$ en ambas cepas. A pesar de que en la cepa ace $2 \Delta / \Delta$ el estudio se complica por su crecimiento en forma de grupos unidos por el septo, se observó que la frecuencia de primeros septos sin anillos de septinas era superior a la observada en la cepa silvestre en estas condiciones de crecimiento (Fig. 19). Resultados similares se obtuvieron al analizar Sep7-GFP en ambas cepas, lo que sugiere que Ace2 podría ser necesaria, directa o indirectamente, para la persistencia del anillo de septinas en hifas.

Este fenotipo es similar al observado previamente en el mutante sep $7 \Delta / \Delta$ (González-Novo et al., 2008), lo que podría indicar que Ace2 participa en la regulación de la estabilidad y dinámica de los anillos de septinas. Para confirmar si esta hipótesis era cierta, se analizó la dinámica de Cdc10 característica del estado específico de hifas mediante ensayos de recuperación de la fluorescencia (FRAP). Para analizar el intercambio de Cdc10 con el citoplasma, se eliminó la fluorescencia del anillo completo mediante iluminación con el laser del microscopio confocal y se analizó su recuperación a lo largo del tiempo, de tal manera que la recuperación de la fluorescencia en el área quemada indicaba la incorporación de nuevas moléculas provenientes del citoplasma. Como se ha descrito previamente (González-Novo et al., 2008), en la cepa silvestre se observó recuperación de la fluorescencia en los anillos, que entre 120 y 160 minutos alcanzaban un valor en torno al 40\% de la fluorescencia 


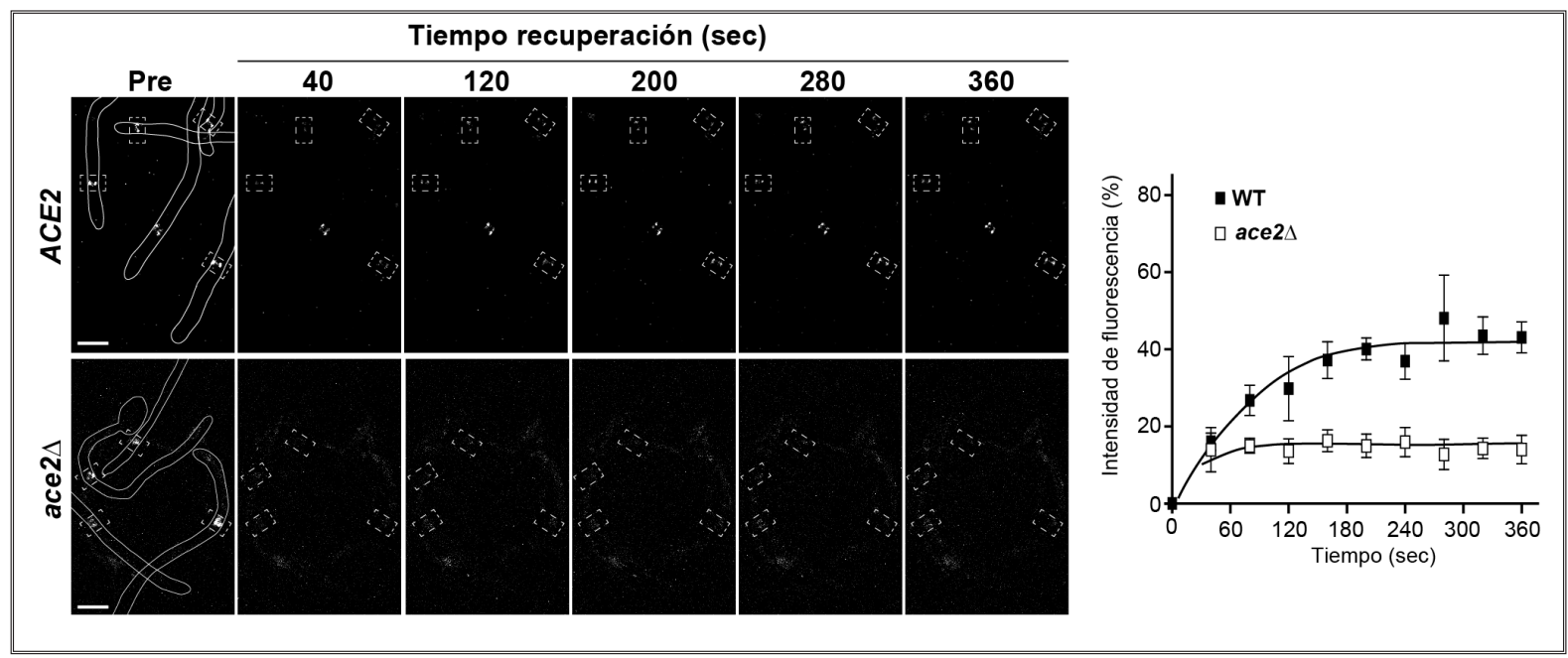

Figura 20. Los anillos de septinas de las hifas del mutante ace2 $\Delta / \Delta$ no se convierten al estado específico de hifas. Dinámica de Cdc10 en las cepas silvestre (ACE2, OL1430) y ace $2 \Delta / \Delta$ (OL1444). La estabilidad del anillo de septinas fue analizada mediante experimentos de FRAP en cepas que contenían un copia cromosomal de CDC10-GFP durante su crecimiento hifal. Anillos completos fueron irradiados con el laser de un microscopio confocal a máxima potencia para eliminar la fluorescencia y posteriormente se tomaron imágenes a los tiempos indicados en la figura para analizar la recuperación de la fluorescencia. La gráfica muestra la cuantificación de la fluorescencia en cada cepa y es la media de tres anillos diferentes. Las barras de error indican la desviación estándar. Barra de escala, $5 \mu \mathrm{m}$.

inicial (Fig. 20). Por el contrario, en el mutante ace $2 \Delta / \Delta$ no se observaba recuperación de la fluorescencia de la septina Cdc10 incluso a tiempos más largos (Fig. 20). Este defecto es similar al descrito para el mutante $\operatorname{sep} 7 \Delta / \Delta$, y junto con los resultados de persistencia de los anillos en hifas, indican que sorprendentemente el factor de transcripción Ace 2 es esencial para la regulación de la dinámica del anillo de septinas en hifas.

\subsubsection{La regulación de la dinámica del anillo de septinas es independiente de la actividad transcripcional de} Ace2.

Considerando que Ace2 es un factor de transcripción, la hipótesis más sencilla para explicar el defecto en la dinámica del anillo de septinas observado en el mutante ace $2 \Delta / \Delta$ es que alguno de los genes regulados por este factor de transcripción tuviera un papel esencial en la conversión de las septinas a su estado específico de hifas. Para comprobar si su papel en la regulación de la dinámica del anillo de septinas estaba mediado por su actividad transcripcional, se marcó Cdc10 con GFP en una cepa heterocigótica en la que uno de los alelos de ACE2 se había sustituido por el gen $A R G 4$ y el otro alelo contenía una copia en la que se había eliminado la secuencia codificante para los dedos de Zinc $(A C E 2-\triangle Z n)$, de modo tal que en la célula existiese la proteína Ace2 pero sin actividad transcripcional (esquema de la construcción en la Figura 21A). Como se muestra en la Figura 21B, la cepa ace $2 \triangle / A C E 2-\triangle Z n$ carece completamente de actividad transcripcional, pues las células crecen formando grupos que se mantienen unidos por el septo, el mismo fenotipo que el mutante ace $2 \Delta / \Delta$.

Las cepas silvestre y ace $2 \Delta / A C E 2-\triangle Z n$ se pusieron a crecer en condiciones de inducción de la filamentación con el objetivo de analizar la dinámica del anillo de septinas en hifas mediante la técnica de FRAP en ausencia de la actividad transcripcional de Ace2. Se observó que, al contrario de lo que ocurre en el mutante ace $2 \Delta / \Delta$, el anillo de septinas presenta una dinámica similar a la de la cepa silvestre, ya que Cdc10 se intercambiaba con el citoplasma y existía una recuperación de la fluorescencia después del quemado en ambas cepas (Fig. 22). Estos resultados sugieren que la actividad transcripcional de Ace2 no es necesaria para la conversión del anillo de septinas al estado específico de hifas y a la vez descartan la posibilidad de que dicha regulación sea indirecta a través de alguna de sus dianas transcripcionales. 


\subsubsection{Análisis de la estructura y secuencia de Ace2 en C. albicans.}

Ace2 es un factor de transcripción implicado en la regulación de la morfogénesis, separación celular, adherencia, formación de "biofilms" y virulencia en modelos de ratón (Kelly et al., 2004). Los resultados presentados en el apartado anterior demuestran claramente que además desempeña un papel directo en la regulación de la dinámica del anillo de septinas durante el crecimiento hifal, y que esta regulación no requiere de su actividad transcripcional. Por tanto, alguno de los dominios presentes en la proteína Ace2- $\Delta Z \mathrm{Zn}$ debería ser el responsable de esta función. Para tratar de identificar qué región podría ser la responsable de la regulación de la dinámica del anillo de septinas en hifas, se analizó la secuencia de la proteína comparándola con las distintas bases de datos de dominios y motivos (Pfam, SMART, InterPro, etc). La mayoría de estos programas identificaban únicamente la presencia de los dos dedos de Zinc de tipo C2H2 cerca del extremo carboxilo de la proteína (aminoácidos 649-673 y 679-701). Sin embargo, la base de datos SMART señalaba la presencia de un posible dominio transmembrana en el extremo N-terminal, entre las posiciones 21 a 43. Este dominio también se encuentra anotado como una posible región transmembrana en la base de datos CandidaDB (http://www.candidagenome.org/), lo que sugiere que si esta región funcionara como un verdadero dominio transmembrana, este factor de transcripción debería estar asociado a membranas en Candida. Sin embargo, esta región transmembrana no parece estar presente en la secuencia de los ortólogos de Ace2 en S. cerevisiae o en S. pombe, y todos los estudios previos en estos organismos o en C. albicans indican que Ace2 es una proteína citoplásmica (Alonso-Nuñez et al., 2005; Dohrmann et al., 1992; O'Conallain et al., 1999)

Para analizar con más detalle estas diferencias, se realizó un alineamiento múltiple de Ace2 con sus homologos en otras especies de hongos y levaduras próximas con el programa ClustalW. Este alineamiento mostró varias observaciones interesantes acerca de Ace2 en C. albicans (Fig. 23). En primer lugar, que el extremo N-terminal de Ace2 era más largo que el de los otros organismos analizados, poseyendo una región adicional de 54 aminoácidos que no estaba presente en la mayoría de ellos y que no se alineaba con la secuencia de S. cerevisiae. En segundo lugar, la existencia de una segunda Met en fase de lectura en $C$. albicans que se alineaba perfectamente con la Met inicial de especies como C. Iusitaniae o C. tropicalis. En tercer lugar, era en esta región adicional del extremo

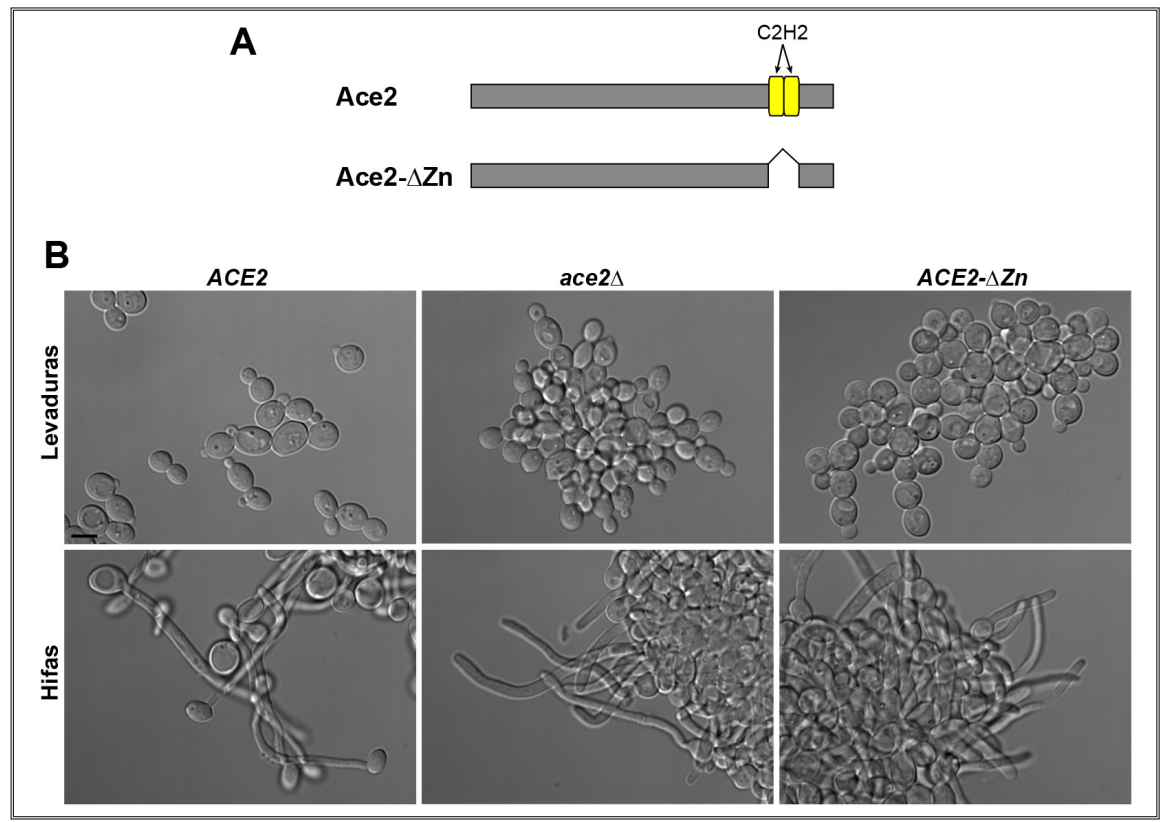

N-terminal donde se localizaba el posible dominio transmembrana, y por ello no estaba presente en otros organismos. Finalmente, en esta región existía una secuencia (HSFRST) que se ajusta perfectamente al consenso descrito como sitio de fosforilación del complejo Cbk1-Mob2 (H-X-X-R/K$\mathrm{X}-\mathrm{S} / \mathrm{T} \quad \mathrm{O} \mathrm{H}-\mathrm{X}-\mathrm{R} / \mathrm{K}-\mathrm{X}-\mathrm{X}-\mathrm{S} / \mathrm{T}$ Mazanka et al., 2008).

Figura 21. Ace2- $\Delta Z n$ no activa la separación celular. A. Esquema representativo de Ace2 y Ace2- $\Delta Z n$. Ace 2 posee 2 dedos de $\mathrm{Zn}$ de tipo $\mathrm{C} 2 \mathrm{H} 2$ (amarillo) cerca del extremo carboxilo que se eliminaron en la construcción Ace2- $\Delta Z n$.B. Fenotipo de la cepa silvestre (BWP17) y de los mutantes ace2 $\Delta / \Delta$ (OL1444) y ace $2 \Delta / A C E 2-\triangle Z n$ (OL1551) creciendo en forma de levaduras y de hifas. Barra de escala, $5 \mu \mathrm{m}$.

Todas estas observaciones indican que la estructura de Ace2 en C. albicans parece 


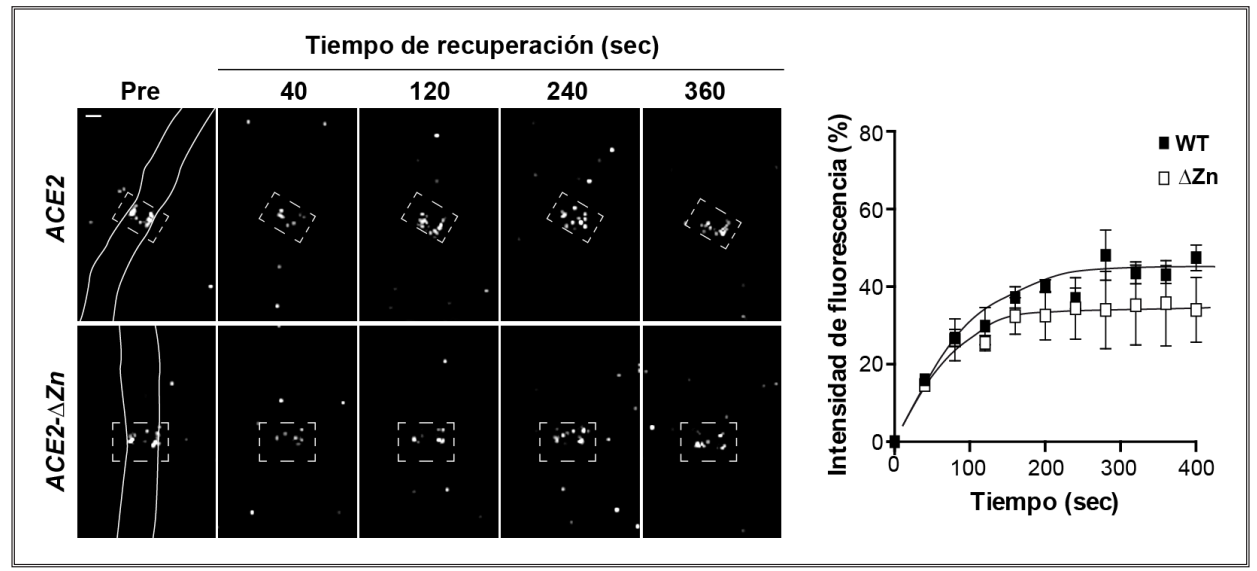

Figura 22. Ace2 regula la dinámica del anillo de septinas independientemente de su actividad transcripcional. Dinámica de Cdc10-GFP en la cepa silvestre BWP17 y en el mutante ace $2 \Delta$ / ACE2- $\triangle Z n$ (OL1551) en hifas. La gráfica muestra la cuantificación de la fluorescencia a lo largo del tiempo y es la media de tres anillos diferentes. Las barras de error indican la desviación estándar. Barra de escala, $1 \mu \mathrm{m}$.

ser diferente a la de otros organismos relacionados, y podrían ser la base para explicar cómo Ace2 regularía la dinámica del anillo de septinas de forma independiente a su actividad transcripcional. Si en $C$. albicans existieran dos puntos alternativos de inicio de la traducción, se producirían dos isoformas de Ace2 de diferentes características. La forma producida a partir de la segunda Met (que denominaremos Met2) tendría un menor tamaño y carecería de la región transmembrana, por lo que su localización previsiblemente sería citoplásmica y/o nuclear, como otros factores de transcripción. Por el contrario, la isoforma de mayor tamaño, cuya traducción comenzaría en la primera Met (Met1), se caracterizaría por poseer un dominio transmembrana y un sitio de fosforilación por Cbk1-Mob2. Estas dos particularidades apuntarían a que esta isoforma podría estar implicada en la regulación de la dinámica del anillo de septinas en hifas dado que su dominio transmembrana la acercaría a las septinas, mientras que una fosforilación por Cbk1-Mob2 podría modular su función, pues se ha descrito el papel de este complejo en la regulación de la morfogénesis y el crecimiento polarizado (Gutiérrez-Escribano et al., 2011).

\subsubsection{ACE2 se transcribe en diferentes RNAs mensajeros.}

La hipótesis planeada anteriormente se basa en el hecho de que existan diferentes formas de mRNAs cuya traducción de lugar a proteínas con distinto extremo amino. Una posibilidad es que existan diferentes puntos de inicio de la transcripción en el promotor de ACE2 que den lugar a mRNAs con un extremo 5' de distinta longitud. Alternativamente, podría ocurrir que se produjera un único transcrito, que en determinadas condiciones se

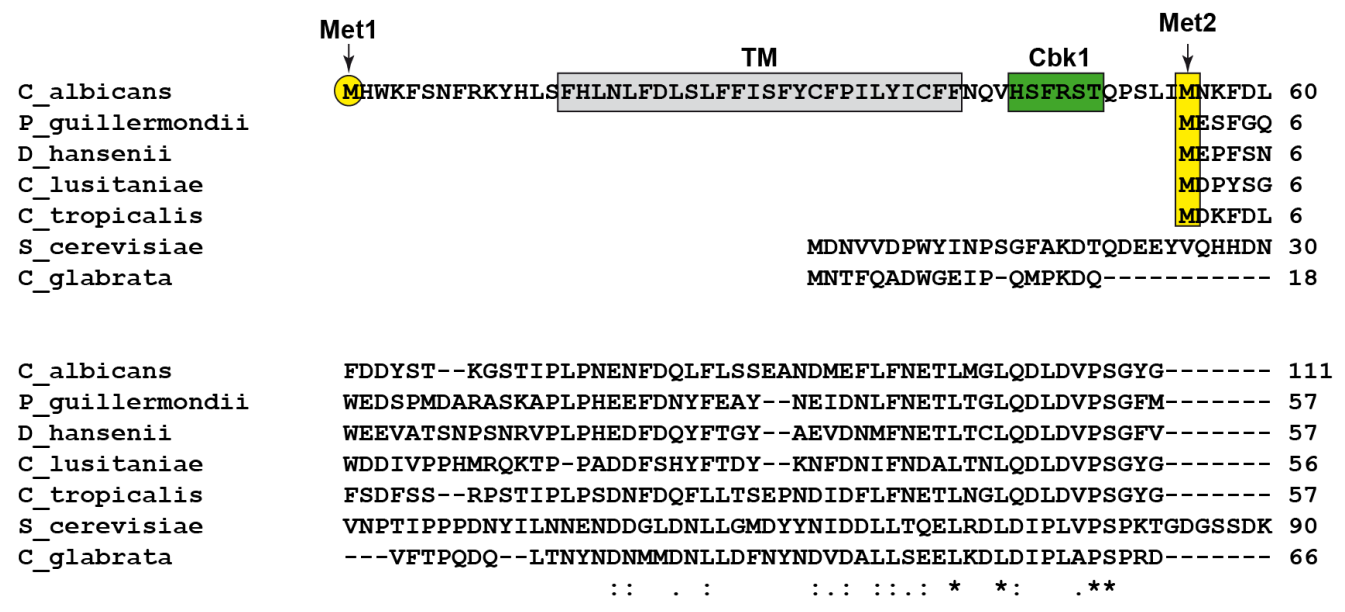

Figura 23. En la región N-terminal de Ace2 de C. albicans existen 54 aminoácidos que no están presentes en otras especies de hongos y levaduras. Alineamiento múltiple generado con el programa ClustalW de la proteína Ace2 de C. albicans, C. tropicalis, Clavispora lusitaniae, Pichia guilliermondii, Debaryomyces hansenii, S. cerevisiae y C. glabrata. Se indican las dos posibles Met que están en fase de lectura (Met1 y Met2), la posible región transmembrana (TM, gris) y el sitio de fosforilación por Cbk1-Mob2 (verde). 
procesara dando lugar a distintos mRNAs. La primera aproximación para analizar los transcritos del gen ACE2 fue comprobar si el primer ATG estaba presente en los mensajeros de este gen. Para ello, se realizó un ensayo de RT-PCR con dos combinaciones de oligonucleótidos, utilizando RNAs obtenidos de hifas y levaduras de la cepa silvestre BWP17. Uno de los oligonucleótidos (1 en Fig. 24A) anillaba sobre el segundo ATG, el oligonucleótido 3 anillaba sobre primer ATG y el oligonucleótido 2 era complementario y común para las dos reacciones. De esta manera, la pareja 1 y 2 amplificaría el cDNA de ACE2 que contuviera el segundo ATG, mientras que la pareja 2 y 3 nos indicaría si el primer ATG estaba presente en los transcritos de este gen. Los productos de la RT-PCR fueron resueltos mediante electroforesis en geles de agarosa. Como puede comprobarse en la Figura 24B, ambas parejas de oligonucleótidos fueron capaces de amplificar fragmentos de DNA, lo que indica que el ATG1 y el ATG2 estaban presentes en los transcritos del gen ACE2 tanto en hifas como en levaduras. A pesar de que esta reacción de PCR no era cuantitativa, parecía que el producto de amplificación de la pareja 1-2 era más abundante que el de la pareja2-3, sugiriendo que la región del ATG1 podría estar presente únicamente en una fracción de los mRNAs de este gen. Además, al comparar la intensidad de los productos de la RT-PCR correspondientes al mensajero mayor entre levaduras e hifas se observó que existía una diferencia en las cantidades, siendo más abundante durante el crecimiento hifal (Fig. 24B). Estos resultados parecen indicar que la región correspondiente al ATG1 está presente en al menos una fracción de los transcritos generados a partir del gen ACE2, y que su abundancia varía dependiendo del estado morfológico de las células.

Para confirmar la existencia de varios transcritos a partir del gen ACE2 y realizar un análisis cuantitativo de sus abundancias en las distintas formas morfológicas de $C$. albicans, se diseñaron dos parejas de oligonucleótidos para PCR cuantitativa a tiempo real (qRT-PCR), que se muestran en la Figura 25A. Nuevamente, la pareja 1-2 amplificaba un fragmento de DNA de unos 100 bp a partir del ATG2 y debería detectar el cDNA total de ACE2. La segunda pareja, compuesta por los oligonucleótidos 3 y 4, amplificaba un fragmento de DNA de tamaño similar a partir del ATG1, que correspondía con la posible región transmembrana. Los resultados cuantitativos obtenidos en este experimento se muestran en la Figura 25B y permiten obtener varias conclusiones: en primer lugar, confirman la existencia de diferentes transcritos a partir del gen ACE2, ya que la cantidad que se amplifica con la pareja 1-2 es muy superior a la obtenida con la pareja 3-4, tanto en hifas como en levaduras. Por tanto, la región entre el ATG1 y el ATG2 estaría presente en una pequeña fracción de los mRNAs de la célula, que en levaduras supone alrededor del 6\% de los mensajeros totales. También se observó que existe un cambio en las abundancias relativas de estas dos formas tras la inducción de la filamentación, ya que mientras que la cantidad de mensajero total de ACE2 se reduce en un 30\%, el mensajero amplificado por el par 3-4 parece ser más abundante, llegando a representar el $24 \%$ de RNA total (Fig. 25B).

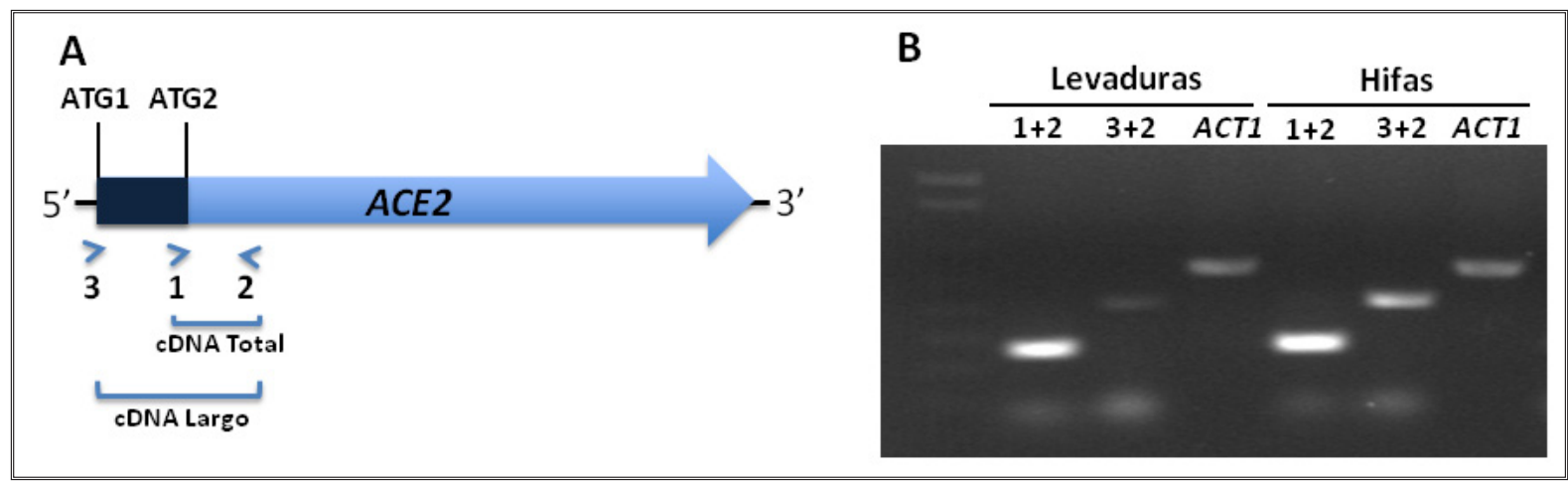

Figura 24. Dos mRNAs se transcriben a partir del gen ACE2 . A. Esquema del sitio de anillamiento de los oligonucleótidos usados en la RTPCR. La pareja 1 y 2 amplifica el total del cDNA de ACE2, pareja 2 y 3 amplifican cDNA del mensajero largo. B. Electroforesis de los productos de la RT-PCR. 
Los resultados anteriores indicaban la existencia de dos poblaciones de mRNAs diferentes del gen ACE2, que podrían originarse a partir de diferentes puntos de inicio de la transcripción o por un procesamiento posttranscripcional a partir de un único mensajero. Para tratar de saber cuál de estas posibilidades era la que tenía lugar en ACE2, se decidió tratar de clonar el extremo 5' de los mRNAs mediante experimentos de 5'-RACE (Rapid Amplification of cDNA Ends). Esta técnica ha sido ampliamente usada en Biología Molecular para la clonación de la secuencia completa de un cDNA a partir de un mRNA (secuencia problema), utilizando tecnología basada en la reacción en cadena de la polimerasa (PCR). El protocolo utilizado se basa en el tratamiento del mRNA problema con una fosfatasa que elimina los grupos fosfato del extremo 5' de los mensajeros parcialmente degradados, de modo que solo aquellos con secuencia completa son susceptibles de mantener su extremo 5' modificado covalentemente ("cap"). Después, este mRNA es tratado con una pirofosfatasa que elimina el "cap" íntegro dejando un grupo fosfato en posición 5' al cual se le puede ligar un oligonucleótido con una secuencia específica que servirá como molde para el proceso de amplificación posterior. Así, este RNA resultante se puede usar como molde para la síntesis de una hebra de cDNA usando un oligonucleótido poli-T con una secuencia específica en su extremo $5^{\prime}$.

En este caso en particular, para identificar el punto de inicio de la transcripción de los mensajeros de ACE2 se uso el RNA obtenido a partir de células creciendo en forma de hifas o levaduras de la cepa silvestre BWP17 y el oligonucleótido poli-T fue sustituido por otro que anillaba específicamente en ACE2, con el fin de amplificar únicamente los cDNAs de este gen. Los fragmentos amplificados fueron clonados en un vector usando el kit comercial StrataClone Blunt PCR Cloning kit@ y posteriormente se secuenciaron los diferentes insertos usando oligonucleótidos que anillaban sobre la secuencia del vector.

El análisis de las secuencias clonadas indicó la existencia de al menos 4 puntos de inicio de la transcripción diferentes. Se obtuvieron cinco clones en los cuales la secuencia empezaba en el nucleótido -411 (considerando como +1 la A del ATG2), dos en el -112, tres en el -84 y tres en el -56. Como se muestra en la Figura 26, tres de estos puntos de inicio $(-112,-84$ y -56) se localizan entre el ATG1 y el ATG2, y corresponderían a varias formas diferentes de un mRNA (que podríamos denominar mensajero corto) cuyo primer AUG es el AUG2, por lo que su traducción daría lugar a una proteína que comienza en la segunda Met y por tanto carecería de la hipotética región transmembrana. El mRNA que comienza en el nucleótido -411 (que podríamos denominar mensajero largo) contendría tanto el AUG1 como el AUG2, y cuya traducción podría dar lugar a una forma de Ace2 que contuviera la región transmembrana y el posible sitio de fosforilación de Cbk1-Mob2.

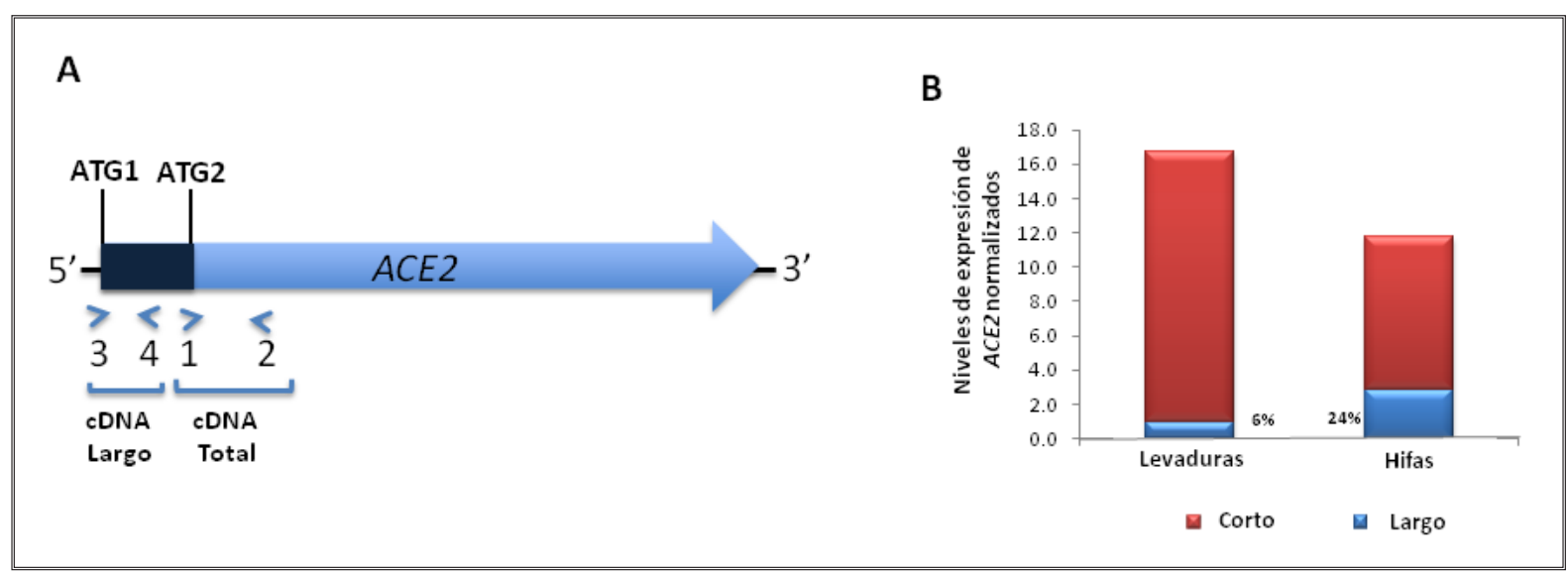

Figura 25. Niveles de transcripción de ACE2. A. Sitio de anillamiento de los cebadores usados en la qRT-PCR. Se utilizaron dos parejas de oligonucleótidos: 3 y 4 amplifican la región que contiene el dominio transmembrana mientras que 1 y 2 amplifican un fragmento de DNA que contiene el ATG2 y que correspondería con el cDNA total de ACE2. B. Ensayo de qRT-PCR en levaduras e hifas de la cepa silvestre BWP17. 
A

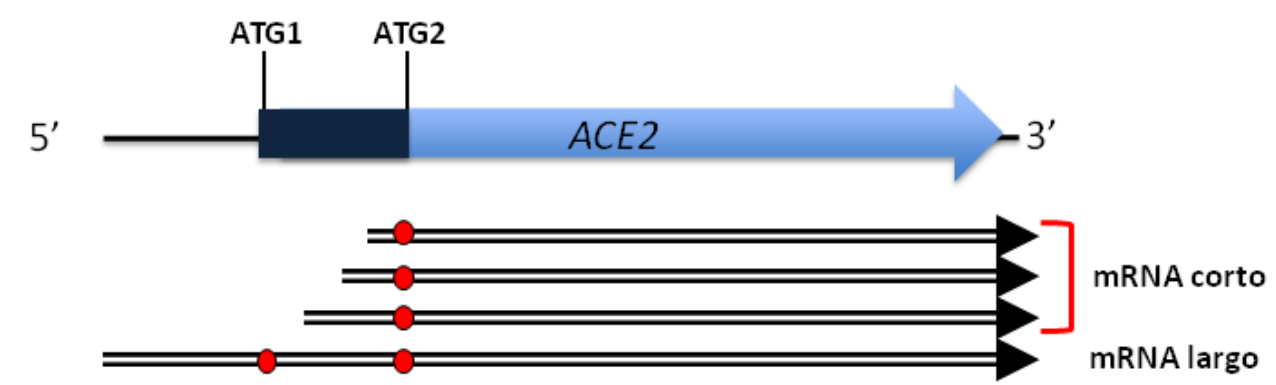

B

$\stackrel{-411}{\nabla}$

СTTCCCTGAAGTTGGCATTAGTTT AGGATTTAGAT AACT AAGTTT AAT AT ACTGATT AACTGTTCT ATATAAGATTCATC

ATGTCT ACTCAAAATTCT ACTGCAAATTCCACTTCTGGATT ATCTCAAACTGCTGATCAGAATGCGTCATTTCAACAGTC

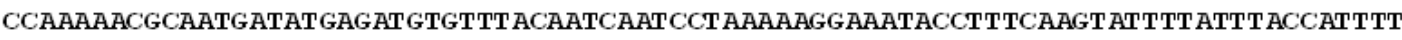
ATG1

TTCTTTTTCTCATTT ACTTTCCCAACTTTTGCACCTCCTTCACT AAAT ATGCATTGGAAATTTCTGAACTTTCGAAAGT

\author{
$-112 \nabla$ \\ $-84 \nabla$
}

$-56 \nabla$

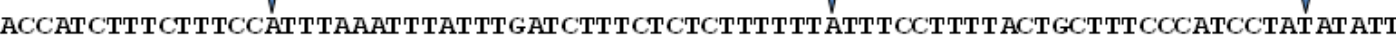

ATG2 (+1)

TGTTTCTTT AATCAAGTCCATTCATTCAGAAGCACACAACCAAGTCTT ATA AT GAT AАATTGACTT

Figura 26. ACE2 se transcribe en diferentes RNAs mensajeros. Sitios de inicio de transcripción identificados mediante la técnica 5' RACE. A. Esquema de los mensajeros de ACE2. Los puntos rojos señalan los AUGs presentes en cada una de las formas. B. Secuencia de ACE2. Los triángulos azules indican sitios de inicio de transcripción identificados. Para la numeración, se ha considerado la A del ATG2 como +1.

Los resultados presentados en este apartado demuestran que existen diferentes puntos de inicio de la transcripción en el gen ACE2 que generarían dos poblaciones de mensajeros con distintos puntos de inicio de la traducción. Considerando los resultados anteriores que indicaban que Ace2 desempeña un papel directo en la regulación de la separación celular en hifas, una hipótesis muy atractiva es que los dos mensajeros se tradujeran dando lugar a dos proteínas con características y funciones diferentes, quizás dependientes del estado morfogenético.

\title{
3.1.5 En C. albicans existen dos isoformas de Ace2.
}

Todos los datos anteriores indican que en C. albicans el gen ACE2 se transcribe en dos poblaciones de mensajeros diferentes, por lo que existe la posibilidad de que también se expresen dos formas diferentes de la proteína. Teóricamente, si el AUG1 se usara para la traducción generaría una proteína de 783 aminoácidos, con un peso molecular estimado de $90,5 \mathrm{kDa}$, y que contendría la hipotética región transmembrana (por lo que se ha denominado Ace2 de membrana o Ace ${ }^{\mathrm{M}}$ ). Por el contrario, la utilización del AUG2 como punto de inicio de la traducción generaría una forma de 729 aminoácidos y un peso molecular estimado de $83,8 \mathrm{kDa}$, que podría funcionar como factor de transcripción al carecer de la región transmembrana (y que se ha denominado Ace2 nuclear o Ace $2^{\mathrm{N}}$ ). Para analizar si esta hipótesis era cierta, se construyó una cepa en la que se marcó la proteína con el epítopo HA en el extremo C-terminal, ya que de existir varias formas con puntos alternativos de inicio de la traducción, esta debería ser una zona común a todas ellas, permitiendo su detección mediante inmunoensayos. Se prepararon extractos de proteínas de levaduras o hifas y se analizaron mediante ensayos de Western blot. Los resultados obtenidos mostraron la presencia de una banda mayoritaria difusa de aproximadamente $95 \mathrm{kDa}$ (Fig. 27A). Es interesante que la abundancia de esta proteína coincide con los niveles de transcripción determinados por qRT-PCR, en los que se observaba que el mRNA total de ACE2 disminuía en hifas (Fig. 25B), pero no se observaban dos proteínas diferentes. 
En muchos organismos Ace2 es una fosfoproteína que migra de forma difusa en los geles de acrilamida. Una posible explicación para el hecho de que en el Western no se observaran las dos formas de la proteína es que Ace $2^{\mathrm{M}}$ tuviera una migración similar a la de las formas fosforiladas de Ace ${ }^{\mathrm{N}}$. Para comprobar si existían dos formas proteicas diferentes en la célula, extractos de proteínas se inmunoprecipitaron con anticuerpos anti$\mathrm{HA}$, se trataron con $\lambda$-fosfatasa ( $\lambda$-PPasa) para eliminar las posibles fosforilaciones, se separaron en geles de acrilamida y se analizaron mediante ensayos de Western blot. Los resultados indicaron que tanto en levaduras como en hifas únicamente se detectaba una forma proteica (Fig. 27B).

Los ensayos de qRT-PCR habían mostrado que existían diferencias significativas en los niveles de transcripción de los dos mensajeros, por lo que cabía esperar que las abundancias relativas de las dos proteínas reflejaran también esta diferencia. Esto significaría que la cantidad de $A c e 2^{\mathrm{M}}$ debería ser bastante inferior a la de $A c e 2^{\mathrm{N}}$, lo que podría dificultar su detección. Con el fin de sortear este obstáculo, se construyeron cepas que expresaban únicamente una de las dos proteínas, las cepas ace $2 \Delta / A C E 2^{M}$ y ace $2 \Delta / A C E 2^{N}$. Para ello, se delecionó mediante uso del marcador ARG4 una de las dos copias del gen, mientras que el alelo restante fue sustituido por una versión etiquetada con el epítopo HA que contenía una mutación puntual que eliminaba uno de los dos ATGs en estudio (cambio de ATG a AAA). Así, una de las cepas contenía una mutación puntual en ATG1, por lo que debería producir únicamente la forma nuclear $\left(A c e 2^{N}\right)$, mientras que la otra contenía la mutación puntual en el ATG2, produciendo sólo la forma $A c e 2^{\mathrm{M}}$. Cuando se analizaron extractos de proteínas de estas dos cepas mediante Western blot (Fig. 27C), se comprobó que en la cepa ace $2 \Delta / A C E 2^{N}$ se observaba una única banda que migraba a la misma altura de la banda observada en la cepa silvestre, confirmando que la forma que se detecta mayoritariamente en la cepa silvestre correspondía a Ace $2^{\mathrm{N}}$. Por el contrario, en la cepa ace $2 \triangle / A C E 2^{\mathrm{M}}$ no $\mathrm{se}$ observaba ninguna banda de un tamaño superior a $A c e 2^{\mathrm{N}}$ que pudiese corresponder al producto del mensajero largo de ACE2 (Fig. 27C). Resultados similares se obtuvieron cuando se realizaron inmunoprecipitaciones de las formas marcadas a partir de $1 \mathrm{mg}$ de proteína total (datos no mostrados).

En algunos casos la estabilidad de las proteínas se ve comprometida por el sitio en el que se colocan los distintos epítopos. Por tanto, cabía la posibilidad de que el marcaje de la proteína $A c e 2^{\mathrm{M}}$ en el extremo carboxilo

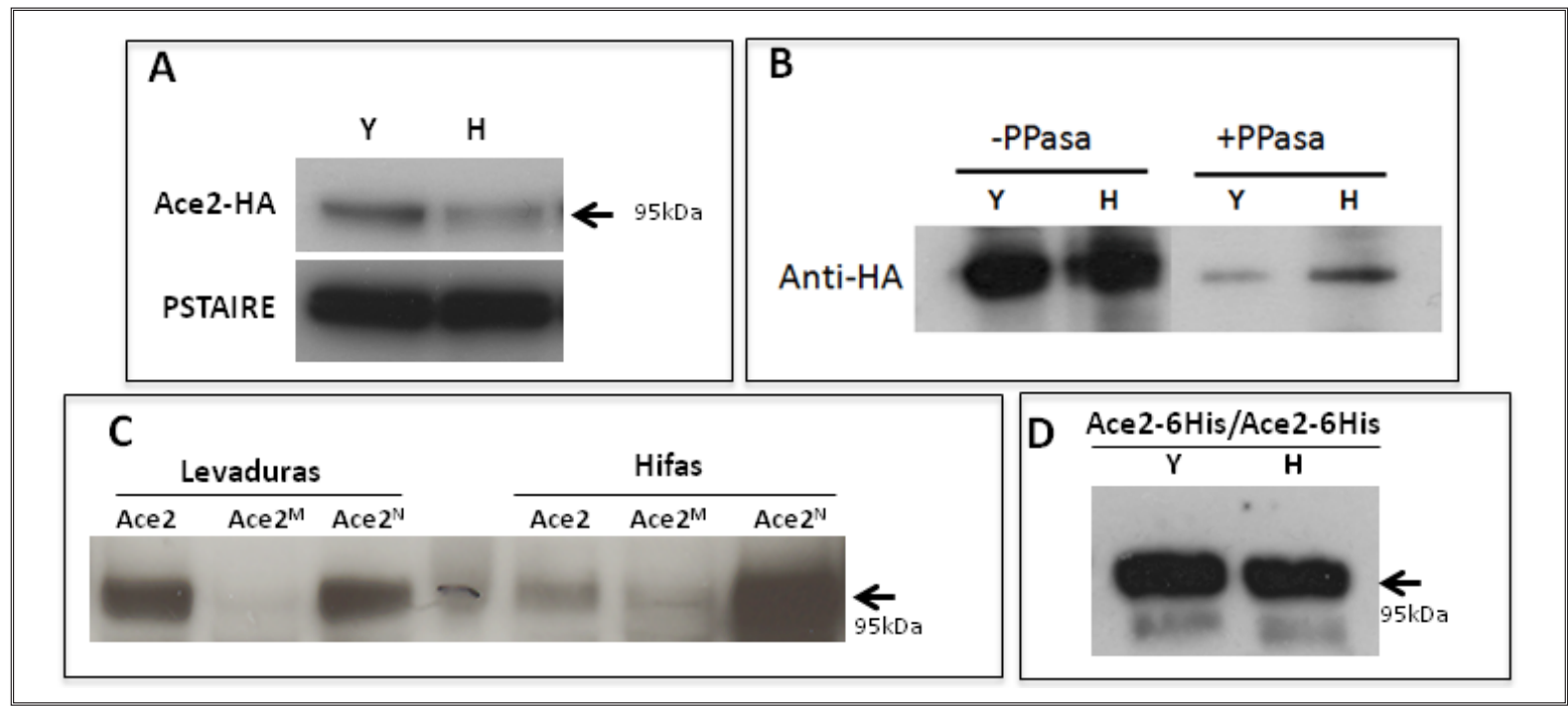

Figura 27. Diferentes aproximaciones usadas para detectar la proteína $A c 2^{\mathrm{M}}$. A. Western blot de extractos celulares de la cepa que contiene ACE2-HA bajo la regulación de su promotor nativo (OL1538). Como control de carga se usó PSTAIRE. B. Tratamiento con $\lambda$-fosfatasa (PPasa) de inmunoprecipitados a partir de la cepa OL1538. C. Análisis mediante Western blot de las cepas que expresan solamente una de

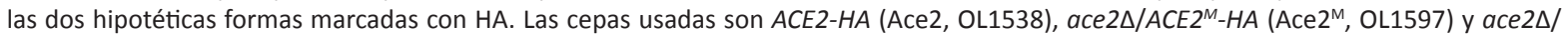
$A C E 2^{N}-H A\left(A c e 2^{N}\right.$, OL1598) D. Purificación en columnas de níquel a partir de la cepa ACE2-6His/ACE2-6His (OL1173). 
estuviera afectando su estabilidad, dificultando su visualización mediante inmunoensayos. Teniendo en cuenta esto, se construyó una cepa en la que se colocó el epítopo HA en el extremo N-terminal, justo después de la Met1 (OL1676). Al mismo tiempo, esta cepa tiene marcada únicamente la proteína que se produce a partir de este inicio de traducción, lo que debería facilitar su detección. Con el fin de concentrar la proteína HA-Ace $2^{\mathrm{M}}$ que pudiera estar presente en los extractos de levaduras o hifas, se realizaron inmunoprecipitaciones a partir de $2 \mathrm{mg}$ de extracto total que se analizaron mediante Western blot. Desafortunadamente, esta aproximación tampoco permitió detectar ninguna proteína que pudiese corresponder a Ace2 ${ }^{\mathrm{M}}$ (resultados no mostrados).

Otra estrategia que se llevo a cabo para tratar de detectar la proteína Ace $2^{\mathrm{M}}$ fue la purificación a gran escala por cromatografía de afinidad. Para ello, se construyó una cepa en la que los dos alelos del gen fueron marcados en el extremo carboxilo con el epítopo poli-histidinas, de tal manera que se pudiese purificar las proteínas en columnas de níquel. Dichas proteínas también estaban marcadas con el epítopo HA, para facilitar la detección de las proteínas purificadas mediante Western blot. A pesar de que se utilizaron hasta $15 \mathrm{mg}$ de extractos de proteínas en la purificación, tampoco se observó ni en levaduras ni en hifas ninguna banda de tamaño superior al de $A c e 2^{\mathrm{N}}$ que pudiese corresponder a la proteína $A c e 2^{\mathrm{M}}$ (Fig. 27D).

Finalmente, también se decidió generar anticuerpos específicos que reconocieran exclusivamente la forma Ace ${ }^{\mathrm{M}}$, por si la adición de cualquier epítopo estuviera afectando su estabilidad. Estos anticuerpos deberían reconocer algún epítopo presente en los primeros 54 aminoácidos, pero al ser ésta una región hidrófoba por la presencia del dominio transmembrana, las posibilidades de elección de un péptido para inmunizar conejos eran bastante limitadas. Se decidió utilizar el péptido CNQVHSFRSTQPSLI, localizado en el extremo C-terminal de esta región de 54 aa y se encargó la generación de anticuerpos a la casa Abyntek. Cuando los anticuerpos se probaron en inmunoensayos, no fue posible detectar ninguna proteína, si bien tampoco fueron capaces de detectar $\mathrm{Ace}^{\mathrm{M}}$ cuando se sobre-expresaba (ver párrafo siguiente).

A pesar de que los niveles de transcripción del mensajero largo de ACE2 representan en torno al $25 \%$ del mRNA total de la célula durante el crecimiento en forma de hifas, las diversas aproximaciones utilizadas para tratar de detectar la forma Ace ${ }^{\mathrm{M}}$ han resultado infructuosas. Por ello, se planteó la posibilidad de que dicha proteína tuviera una vida media muy corta en la célula y se degradara rápidamente. Alternativamente, también podría ocurrir que la traducción de este mRNA fuera poco eficiente, o que ocurriera bajo unas condiciones determinadas de crecimiento, ya que la región líder de este mensajero es más larga (249 nucleótidos) que el promedio de los genes (80-100 nucleótidos). Para tratar de aumentar la expresión de Ace2 ${ }^{\mathrm{M}}$, se recurrió al uso de promotores regulables de expresión fuerte como el promotor del gen MET3, el cual regula su expresión en respuesta a estímulos nutricionales (Care et al., 1999). Se construyeron dos cepas en las cuales este promotor se clonó delante del ATG1 o del ATG2 (Fig. 28A), de modo que cada cepa sobre-expresara solamente una de las dos proteínas. Además, ambas construcciones fueron etiquetadas con el epítopo HA para su visualización. Estas cepas se pusieron a crecer en condiciones de inducción durante 3 horas y se prepararon extractos proteínas para su análisis por Western blot. Los resultados mostraron que en la cepa que sobre-expresaba la proteína Ace ${ }^{\mathrm{N}}$ aparecía una banda de un tamaño similar a la observada en la cepa con el promotor nativo, cuya abundancia era unas 5 veces superior a la de la cepa silvestre. De igual modo, en la cepa que sobre-expresaba Ace ${ }^{\mathrm{M}}$ aparecía una banda única, de tamaño superior a $A c e 2^{N}$, que presentaba una intensidad similar a la sobre-expresión de Ace $^{\mathrm{N}}$, y que por peso molecular podría corresponder a la proteína producida por traducción a partir del ATG1 (Fig. 28B). Resultados similares se obtuvieron al analizar estas cepas durante la filamentación. 
Los resultados expuestos en este apartado muestran que no ha sido posible detectar la proteína Ace ${ }^{\mathrm{M}}$ a partir de su promotor nativo, a pesar de las múltiples estrategias probadas, lo que podría indicar que es una proteína muy poco abundante en la célula o de una vida media muy corta. Sin embargo, cuando se utiliza un promotor regulable de expresión fuerte es posible detectar una forma de mayor tamaño del factor de transcripción Ace2 $\left(A c e 2^{\mathrm{N}}\right)$, que corresponde perfectamente con el tamaño esperado para $A c e 2^{\mathrm{M}}$.

\subsubsection{La región $\mathrm{N}$-terminal de Ace2 funciona como dominio transmembrana.}

Como se ha comentado previamente, una de las características del extremo N-terminal presente en Ace ${ }^{\mathrm{M}}$ es la existencia de una hipotética región transmembrana. Si esta predicción bioinformática fuera cierta, cabría esperar que esta región de la proteína fuese capaz de conducir a la membrana a una proteína heteróloga. Para comprobar esta hipótesis, se realizó una construcción en la que se clonó la región que codifica para los primeros 54 aa de Ace 2 que contienen la región transmembrana en el extremo 5'del marco de lectura de la proteína fluorescente verde (GFP) y bajo la regulación del promotor TEF de Ashbya gossypii (Fig. 29). Como control se utilizó una construcción similar que contenía el gen GFP bajo el control del mismo promotor. Estas construcciones permitían analizar por microscopía de fluorescencia la localización de ambas proteínas y comprobar si la proteína de fusión TM ${ }^{\text {Ace2_-GFP }}$ presentaba la misma localización citoplásmica que la GFP o conseguía localizarse en algún compartimento de membrana. Ambas construcciones se insertaron en el genoma de la cepa BWP17 y se comprobaron mediante PCR y secuenciación. El análisis por microscopía de fluorescencia reveló que, como cabía esperar, en la cepa que contenía la GFP carente de la región transmembrana se observaba una fluorescencia difusa en todo el

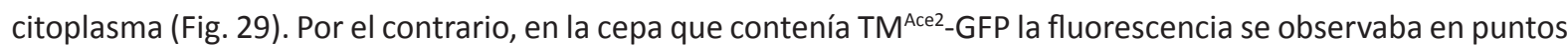
dispersos en el citoplasma, lo que sugiere que esta proteína está asociada a alguna membrana celular, bien el aparato de Golgi o algún tipo de vesículas secretoras. En algunos casos también se observó un patrón de
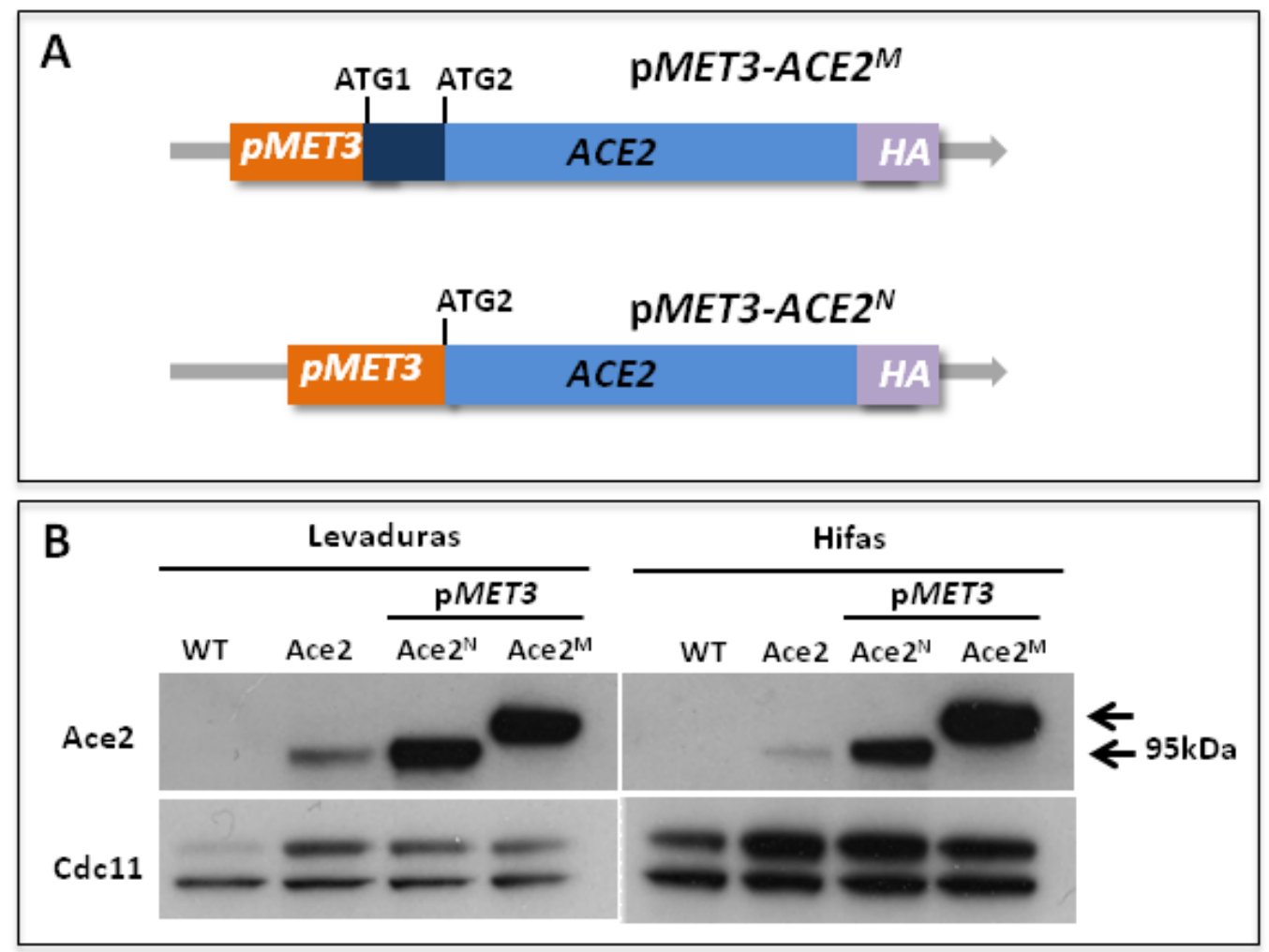

Figura 28. Ace ${ }^{\mathrm{M}}$ es una proteína de mayor tamaño que $\mathrm{Ace}^{\mathrm{N}}$. A. Esquema de las construcciones utilizadas para sobreexpresar las proteínas Ace $2^{\mathrm{M}}$ y Ace2 ${ }^{\mathrm{N}}$. B. Análisis mediante Western blot de extractos proteicos de las cepas silvestre (WT, OL1202), ACE2-HA (OL1538), pMET3ACE2 ${ }^{M}-H A(O L 1203)$ y $p M E T 3-A C E 2^{N}-H A(O L 1111)$ en levaduras e hifas. Como control de carga se utilizó anti-Cdc11. 


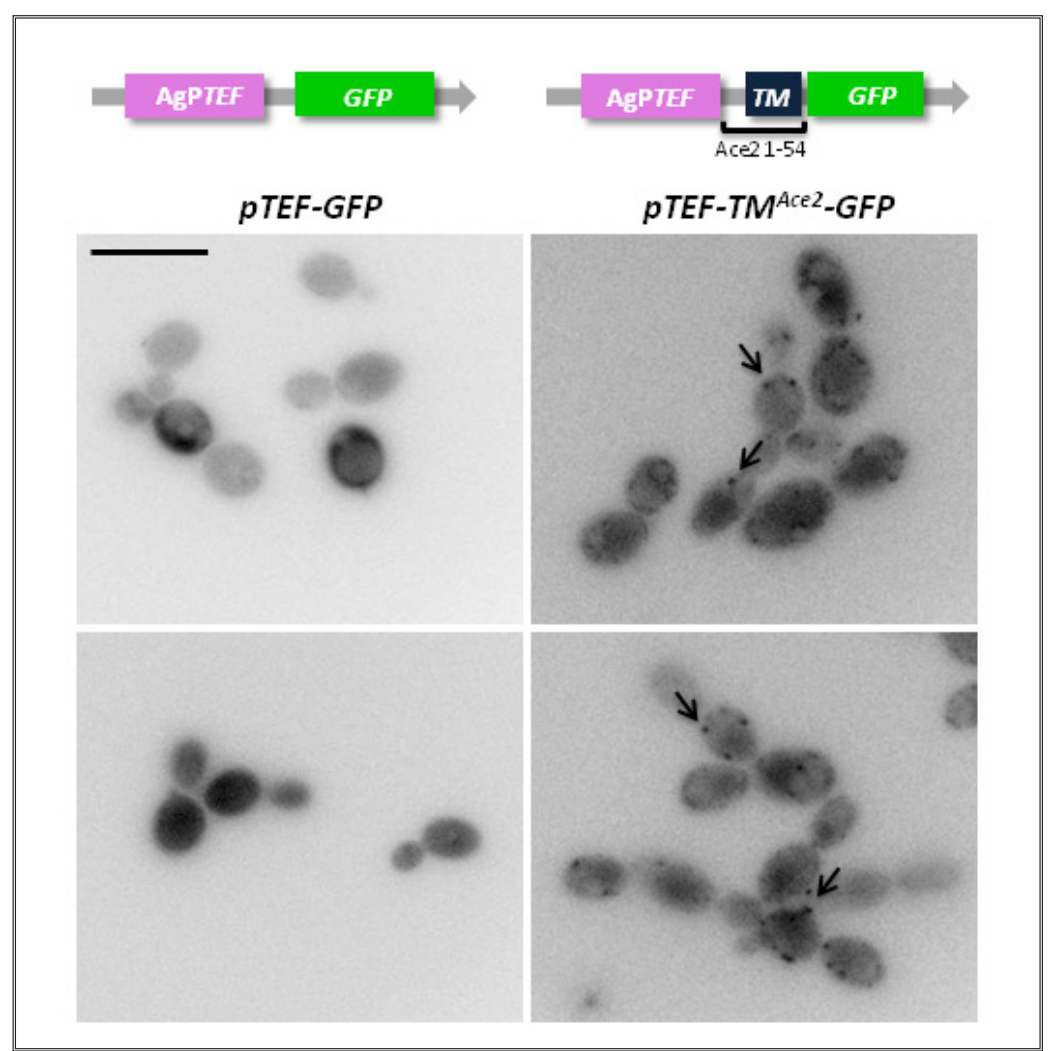

Figura 29. El extremo N-terminal de Ace2 es capaz de dirigir a una proteína heteróloga a compartimentos de membrana. En la parte superior se muestran los esquemas de las construcciones utilizadas. Los paneles inferiores muestran imágenes de microscopía de fluorescencia de levaduras de las cepas pTEF-GFP (OL1969) y pTEF-TM ${ }^{\text {Ace2 }}$-GFP (OL1970). Las flechas señalan la fluorescencia en los puntos en la periferia de la célula. fluorescencia perinuclear, típico de las tinciones de proteínas de retículo endoplasmático. Estos resultados respaldan y soportan la hipótesis de que el extremo $\mathrm{N}$-terminal de Ace2 podría comportarse como un verdadero dominio TM y ser capaz de dirigir una proteína a la membrana.

\subsubsection{Ace $2^{\mathrm{M}}$ y $A c e 2^{\mathrm{N}}$ son proteínas fosforiladas.}

Para realizar una caracterización más detallada de las proteínas Ace $^{\mathrm{M}}$ y $A c e 2^{\mathrm{N}}$, se decidió usar las construcciones que sobreexpresaban ambas formas mediante el promotor del gen MET3, a pesar de que en ambos casos los niveles de las proteínas no son fisiológicos. Sin embargo, el uso de estas construcciones permitía realizar una caracterización

bioquímica preliminar y comprobar si existía alguna diferencia significativa entre ambas formas. En primer lugar, los análisis bioinformáticos de la secuencia de Ace2 en C. albicans indicaban la existencia de múltiples sitios de fosforilación. Existen 7 sitios posibles de fosforilación por CDKs que se ajustan al consenso completo (S/T-P-X-K/R) y otros 20 incompletos (S/T-P) (Holmes y Solomon, 1996). También hay tres posibles sitios de fosforilación por el complejo Cbk1-Mob2 (H-X-X-R/K-X-S/T o H-X-R/K-X-X-S/T, Mazanka et al., 2008), uno de los cuales se localiza en los primeros 54 aa de $A c e 2^{\mathrm{M}}$, como se ha comentado previamente. Estas observaciones, junto con el hecho de que en los ensayos de Western blot realizados se observaran bandas difusas por encima del tamaño esperado, sugieren que ambas formas podrían ser fosfoproteínas. Por tanto, se realizaron ensayos para comprobar el estado de fosforilación de ambas formas. Para ello, se realizó la purificación de las dos proteínas mediante inmunoprecipitaciones con bolas magnéticas acopladas al anticuerpo anti-HA. Las proteínas retenidas fueron incubadas con la $\lambda$-fosfatasa durante 30 minutos a $28^{\circ} \mathrm{C}$ y posteriormente se eluyeron para su separación electroforética. El análisis por Western blot mostró que el tratamiento con la fosfatasa provocó la desaparición de las bandas de mayor peso molecular en la cepa $p M E T 3-A C E 2^{N}-H A$, apareciendo únicamente la banda correspondiente a la forma de menor peso molecular (Fig. 30). En la cepa pMET3-Ace $2^{M}-H A$ también se observaron cambios en el patrón de movilidad electroforética, aunque en este caso no fue tan evidente como en ACE2-HA y $p M E T 3-A C E 2^{N}$-HA. Como control, también se realizaron los ensayos con la cepa ACE2-HA, que contiene la proteína bajo el control de su propio promotor. Estos resultados indican que Ace ${ }^{\mathrm{N}}$ es una proteína fosforilada, mientras que $A c e 2^{\mathrm{M}}$ parece estar menos modificada por quinasas.

\subsubsection{Las dos formas de Ace2 fraccionan en diferentes compartimentos subcelulares.}

Los experimentos mostrados en el apartado 3.1.6 indicaban que el extremo N-terminal de Ace2 posee un 
dominio transmembrana que es capaz de dirigir a la proteína GFP a las membranas de la ruta secretora. Ya que dicho dominio está presente únicamente en $A c e 2^{\mathrm{M}}$, cabría esperar que presentara una localización subcelular diferente a la de $A c e 2^{N}$, presumiblemente en algún compartimento membranoso. Para comprobar esta hipótesis, se realizaron experimentos de fraccionamiento subcelular por centrifugación diferencial en gradientes de sacarosa con las cepas que contenían PMET3-ACE2 ${ }^{M}-H A$ y $P M E T 3-A C E 2^{N}-H A$.

De cada uno de los gradientes se obtuvieron 18 y se analizaron con distintos anticuerpos mediante Western blot. Además de anticuerpos anti-HA para detectar las distintas formas de Ace2, se utilizaron anticuerpos comerciales contra distintas proteínas para poder determinar en qué fracciones sedimentaba cada una de ellas. Los resultados indicaron que Ace $2^{\mathrm{N}}$ y $A c e 2^{\mathrm{M}}$ fraccionaban en distintas regiones del gradiente. Así, $A c e 2^{N}$ se localizaba en las fracciones más ligeras del gradiente (2 a 8$)$, coincidiendo mayoritariamente con las fracciones en las que se distribuía Pol2 (4 a 8), la subunidad catalítica de la ARN polimerasa II utilizada como marcador de núcleo (Fig. 31). La proteína Ace ${ }^{\mathrm{N}}$ que sedimenta en la fracción 2 (donde no hay marcadores nucleares) podría corresponder con una fracción de esta forma que se encuentra en el citoplasma, pues se ha descrito que Ace2 se transporta entre núcleo y citoplasma (O'Conallain et al., 1999). Cuando se analizaron extractos celulares obtenidos a partir de hifas, se observó una distribución similar de $A_{c e} 2^{N}$, aunque en este caso, la cantidad presente en la fracción 2 era menor. Estas observaciones sugieren que

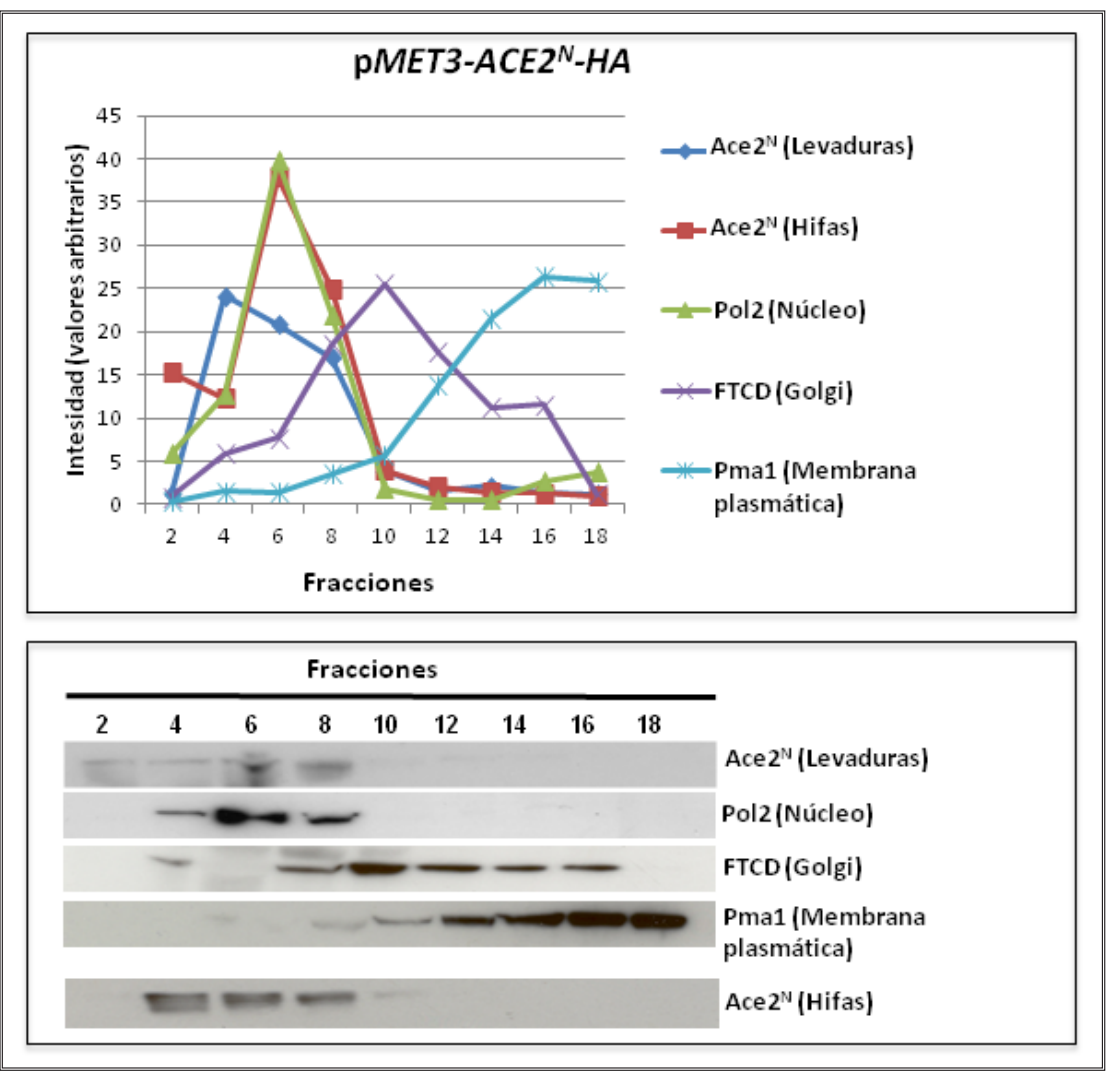

Figura 31. Ace2 $^{\mathrm{N}}$ sedimenta con marcadores nucleares. Fraccionamiento subcelular en gradientes de sacarosa (20-60\%) de extractos celulares de la cepa $p M E T 3-A C E 2^{N}$. HA (OL1111) crecida en forma de levaduras o hifas. Las fracciones fueron analizadas por Western blot utilizando anticuerpos específicos para proteínas usadas como marcadores de localización subcelular. La gráfica superior representa la cuantificación de la intensidad de las señales en las distintas fracciones medida en unidades arbitrarias . 


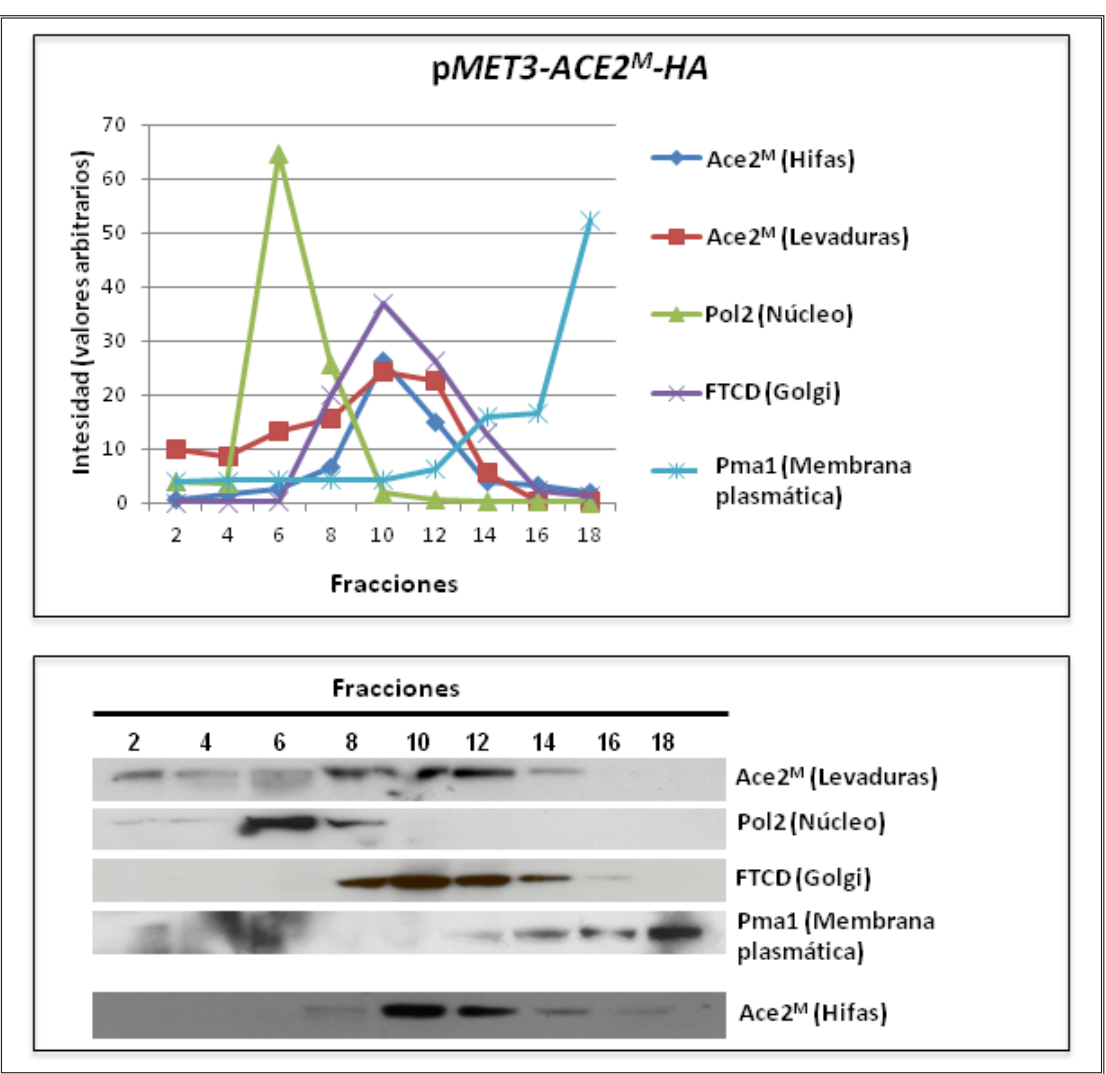

Figura 32. Ace $2^{\mathrm{M}}$ sedimenta parcial-mente con marcadores del aparato de Golgi. Fraccionamiento subcelular en gradientes de sacarosa (20-60\%) de extractos celulares de la cepa $p M E T 3-$ ACE $^{M}{ }_{-}$ HA (OL1203) crecida en forma de levaduras o hifas. Las fracciones fueron analizadas por Western blot utilizando anticuerpos específicos para proteínas usadas como marcadores de localización subcelular. La gráfica superior representa la cuantificación de la intensidad de las señales en las distintas fracciones medida en unidades arbitrarias. la isoforma denominada $A c e 2^{\mathrm{N}}$ podría ser la que actuaría como un factor de transcripción regulando la expresión de los genes de separación celular.

Por el contrario, cuando se analizó $A c e 2^{\mathrm{M}}$ se comprobó que esta proteína sedimentaba de una forma más dispersa en los gradientes (Fig. 32), desde la fracción 2 a la 14, aunque la mayor intensidad se detectaba en las fracciones más densas ( 8 a 12). Cuando esta distribución se comparó con la de los distintos marcadores usados, se comprobó que $\mathrm{Ace}^{\mathrm{M}}$ cosedimentaba parcialmente con el marcador del aparato de Golgi (fracciones 8-14) y no con el marcador nuclear. Además, Ace $2^{\mathrm{M}}$ y el marcador

de membrana plasmática (la ATPasa de membrana Pma1) localizaban en fracciones diferentes, lo que indicaba que $A c e 2^{\mathrm{M}}$ no está asociada a esta membrana. Cuando se analizaron extractos celulares obtenidos a partir de hifas, se observó una distribución similar de $A c e 2^{\mathrm{M}}$, aunque en este caso la cantidad que sedimentaba en las fracciones más ligeras era inferior que en hifas. Estos resultados podrían indicar, que Ace ${ }^{\mathrm{M}}$ parece estar asociado a algún tipo de vesículas que heterogéneas que sedimentan de forma dispersa en los gradientes, existiendo una cierta co-sedimentación con marcadores del aparato de Golgi.

Los resultados anteriores que mostraban que $A c e 2^{\mathrm{N}}$ y $A c e 2^{\mathrm{M}}$ sedimentaban en fracciones diferentes de los gradientes de sacarosa animaron a probar si era posible detectar la isoforma Ace ${ }^{\mathrm{M}}$ con su promotor nativo. Para ello, se usó la cepa que contenía los dos alelos de ACE2 marcados con $6 \mathrm{His}$ y se prepararon extractos a partir de levaduras e hifas para su análisis en gradientes de sedimentación. Los resultados obtenidos indicaron que se detectaba una proteína que tenía un patrón de sedimentación y de movilidad electroforética similar a la observada en la cepa $P M E T 3-A c e 2^{N}$, que fraccionaba con el marcador de localización nuclear, pero no se observó ninguna banda adicional en las fracciones más densas que pudiese corresponder a Ace $2^{\mathrm{M}}$ (Fig. 33 ).

Estos resultados sugieren que $A c e 2^{\mathrm{N}}$ podría ser la forma que funciona como factor de transcripción, mientras que $A c e 2^{\mathrm{M}}$ al localizarse en fracciones de membrana, podría desempeñar una función diferente, pudiendo estar implicada en la regulación de la dinámica del anillo de septinas. 


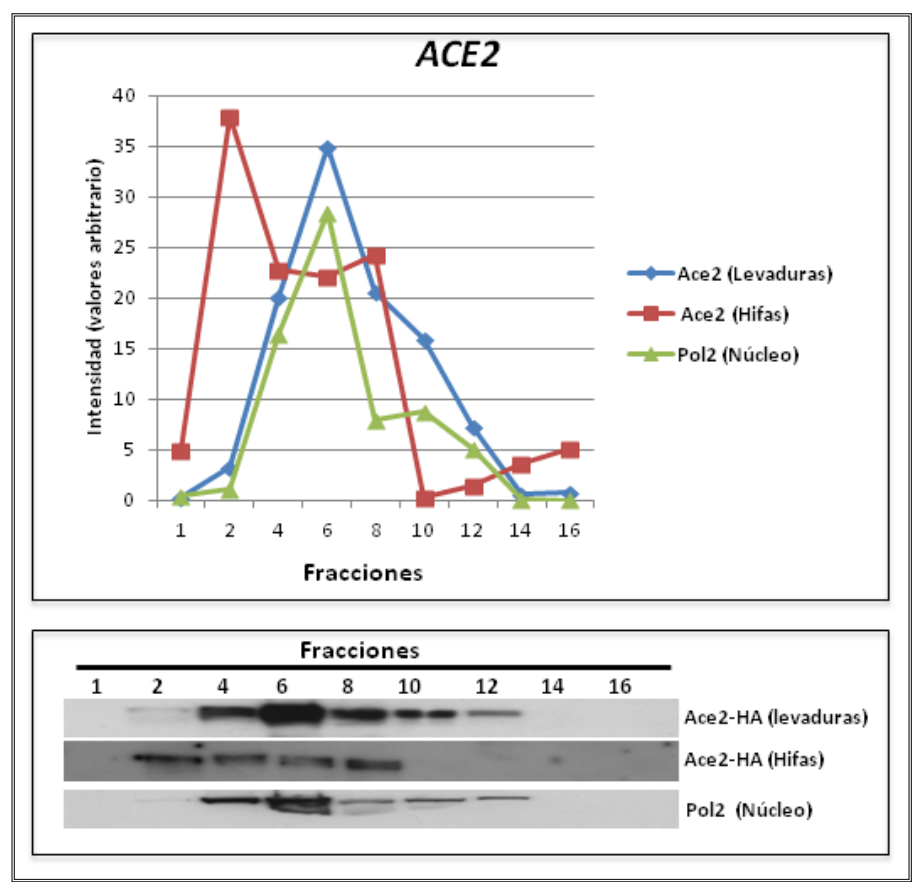

Figura 33. Ace2 expresado a partir de su promotor nativo sedimenta con el marcador de núcleo. Fraccionamiento subcelular en gradientes de sacarosa de extractos celulares de la cepa ACE2-6HIS (OL1173). Las fracciones fueron analizadas por Western blot utilizando anticuerpos específicos para proteínas usadas como marcadores de localización subcelular. La gráfica superior representa la cuantificación de la intensidad de las señales en las distintas fracciones medida en unidades arbitrarias.

\subsubsection{En C. albicans Ace2 se localiza en el} núcleo y en puntos citoplásmicos.

Los análisis realizados mediante fraccionamiento subcelular sugerían una localización diferencial para las dos formas de Ace2. Para confirmar estos resultados, se procedió a analizar la localización de la proteína mediante microscopía de fluorescencia. Para ello, se construyó una cepa en la cual las dos copias de ACE2 fueron etiquetadas con la GFP para amplificar la intensidad de la señal. La funcionalidad de la proteína de fusión fue comprobada mediante el análisis de fenotipo, pues las células de levaduras carentes de Ace 2 tienen defectos en separación celular, como se mostró en la Figura 17.

Cuando las células crecían en forma de levaduras, se observó que la fluorescencia mayoritaria se detectaba en el núcleo de la célula hija, aunque también existían células con yema grande en las que tanto la célula madre como la hija poseían Ace2 en el núcleo, como se ha descrito previamente (Kelly et al., 2004). Además de esta fluorescencia mayoritaria, en numerosas células era posible observar algunos puntos fluorescentes que se localizaban cerca del contorno de la célula, y que tal vez podrían corresponder al aparato de Golgi o a algún tipo de vesículas secretoras o endocíticas (Fig. 34A). De la misma forma, cuando se inducía la formación de hifas también se observaba fluorescencia en zonas que correspondían a los núcleos, pues Ace2 también tiene localización nuclear en hifas a pesar de que la separación celular está inhibida (Wang, et al., 2009) y un patrón punteado aleatorio similar al observado en levaduras (Fig. 34B).

Teniendo en cuenta los resultados previos que indicaban que el extremo amino de Ace ${ }^{\mathrm{M}}$ podría funcionar como un dominio transmembrana, y que en el fraccionamiento subcelular parecía sedimentar en fracciones correspondientes al aparato de Golgi o vesículas, se planteó la posibilidad de que los puntos citoplásmicos pudiesen corresponder a Ace $2^{\mathrm{M}}$. Para comprobar si esta hipótesis era cierta, se construyo una cepa en la que la GFP había sido fusionada a Ace $2^{\mathrm{M}}$. Cuando se analizó la fluorescencia en esta cepa, se comprobó que la fluorescencia nuclear había desaparecido, pero el patrón citoplásmico punteado de la cepa silvestre se mantenía (Fig. 35). Este resultado apoya la idea de que $\mathrm{Ace} 2^{\mathrm{M}}$ podría presentar una localización subcelular diferente a $\mathrm{Ace} 2^{\mathrm{N}}$.

Para tratar de confirmar estos resultados, se construyeron las cepas $p M E T 3-A c e 2^{N}$-GFP y $p M E T 3-A c e 2^{M}-G F P$ (ver esquemas de las construcciones en la Figura 36A), las cuales sobre-expresaban cada una de las proteínas fusionadas con la GFP, lo que permitía comprobar la localización de cada isoforma de forma independiente, facilitando al mismo tiempo su visualización por microscopia de fluorescencia. Como control, para descartar que el patrón punteado observado en la cepa $p M E T 3-A c 2^{M}-G F P$ pudiera ser debido a autofluorescencia interna de las células, se utilizó una cepa que contenía una construcción similar pero la proteína estaba marcada con el 


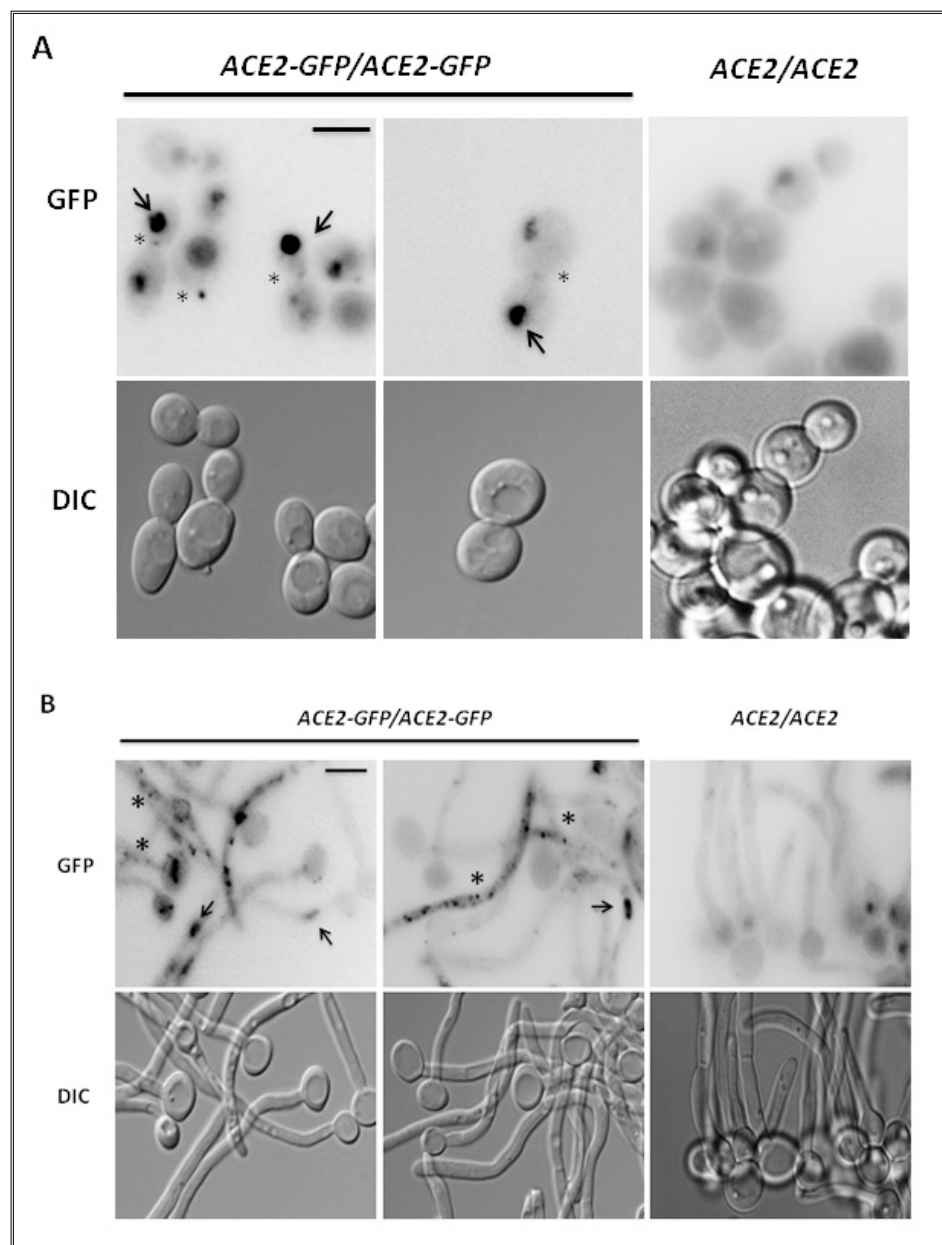

Figura 34. Localización de Ace2 en levaduras e hifas. Microscopia de fluorescencia de la cepa ACE2-GFP/ACE2-GFP (OL1036) crecida en forma de levaduras (A) o tras la inducción de la filamentación (B). Los asteriscos señalan la fluorescencia que se localiza en forma de puntos citoplásmicos; las flechas la localización nuclear. Como control de la autofluorescencia, se muestra una cepa que carece de GFP (ACE2) ACE2) crecida en las mismas condiciones. Barra de escala, $5 \mu \mathrm{m}$.

nuclear (bien en el núcleo de la célula hija o en la célula madre e hija) y Ace ${ }^{\mathrm{M}}$ una forma asociada a algún tipo de vesículas (el aparato de Golgi o vesículas de transporte), localización que podría estar mediada por el dominio transmembrana presente en su extremo N-terminal.

\subsection{FUNCIONES DE Ace2 EN C. albicans}

En S. cerevisiae, la separación celular se produce por la degradación del septo primario que existe entre la célula madre y la célula hija al final de cada división celular. El factor de transcripción Ace 2 controla la expresión de genes específicos de la célula hija, tales como la quitinasa codificada por CTS1 y las glucanasas codificadas por ENG1 o SCW11, siendo estas enzimas las encargadas de la degradación del septo después de la citoquinesis, lo que conducen a la separación celular. Su acumulación en el núcleo depende de la fosfatasa epítopo HA en lugar de con GFP (pMET3Ace $\left.2^{M}-H A\right)$. La sobreexpresión de estas proteínas no presentó ningún defecto aparente en ninguna de las dos cepas.

En la cepa $p M E T 3-A c e 2^{N}-G F P$ solamente se observó fluorescencia nuclear, bien únicamente en la célula hija o en las células madre e hija (Fig. 36B), similar a las células que expresaban Ace2-GFP a partir de su propio promotor (Fig. 34A), pero en ningún caso aparecía el patrón de puntos citoplásmicos. Por el contrario, la cepa pMET3-Ace $2^{M}$-GFP carecía de fluorescencia nuclear pero presentaba el mismo patrón de fluorescencia caracterizado por puntos fluorescentes en la periferia y citoplasma celular (Fig. 36C). El control pMET3-Ace2 ${ }^{\mathrm{M}}$ $H A$ presentaba una fluorescencia difusa en el citoplasma y vacuola, lo que parece confirmar que los puntos observados corresponden a Ace2 ${ }^{\mathrm{M}}$ (Fig. 36C y 36D).

Estos resultados indican que las dos formas de Ace2 se localizan en compartimentos subcelulares diferentes, siendo $A c e 2^{\mathrm{N}}$ una proteína de localización mayoritariamente 


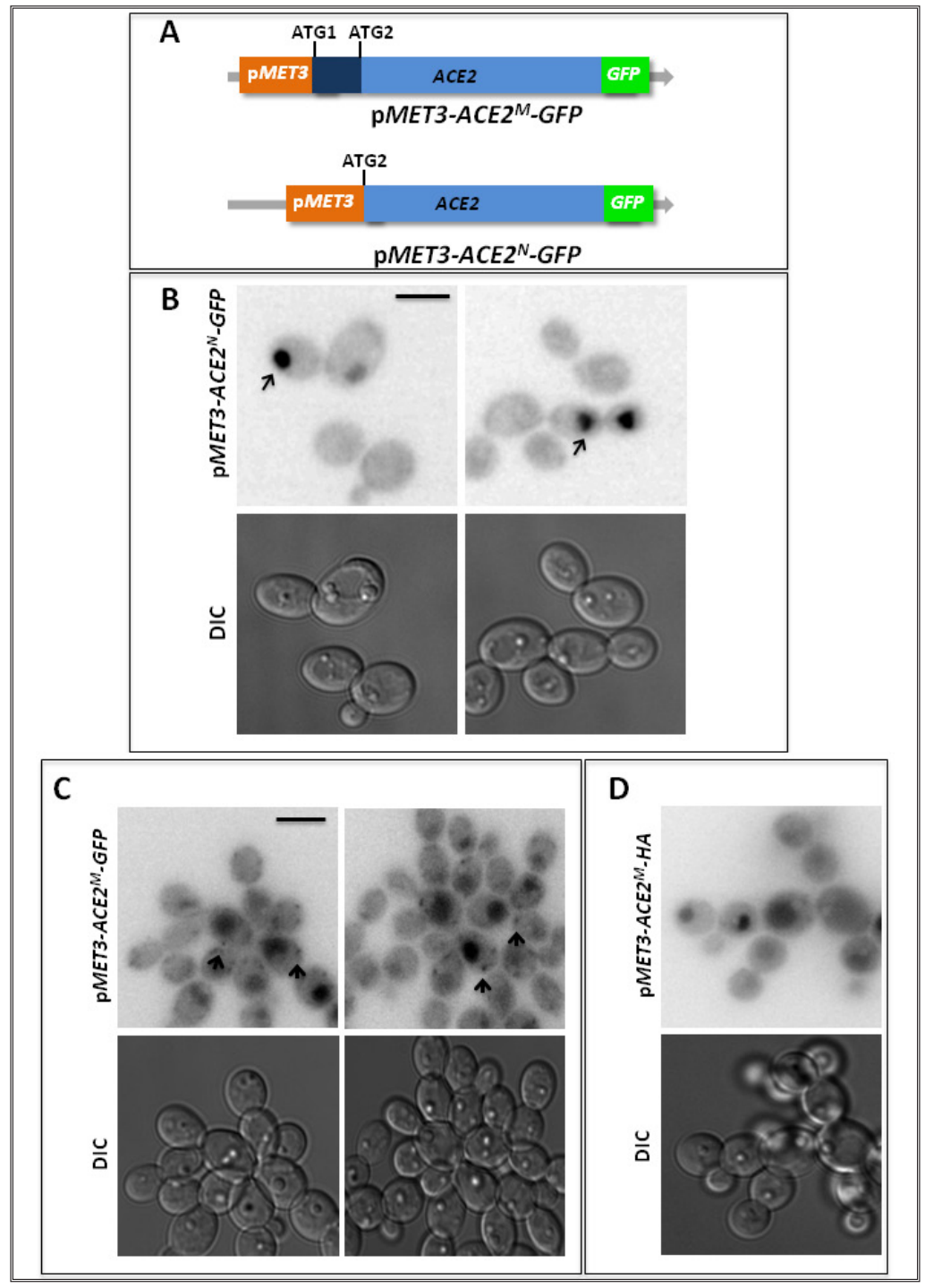

Figura 36. Localización de $A c e 2^{\mathrm{N}}$ y $A c e 2^{\mathrm{M}}$ en sobreexpresión. A. Esquema de las construcciones utilizadas para sobreexpresar las dos formas de Ace 2 etiquetado con la GFP. B y C. Imágenes de fluorescencia y contraste interferencial (DIC) de las cepas PMET3-ACE2 $2^{N}-G F P$ y PMET3-ACE2 ${ }^{M}-G F P$ (OL1978 y OL1976, respectivamente) creciendo en forma de levaduras. D. Imágenes de fluorescencia y DIC de la cepa pMET3-ACE2 ${ }^{M}-H A$ (OL1203) usada como control negativo. Barra de escala, $5 \mu \mathrm{m}$.

Cdc14 y de la señalización de la ruta RAM (Baladrón et al., 2002; ColmanLerner et al., 2001; Nelson et al., 2003; Weiss et al., 2002). Todos estos componentes están conservados en $C$. albicans, donde desempeñan una función similar durante el crecimiento en forma de levaduras (Clemente-Blanco et al., 2006; Kelly et al., 2004; Song et al., 2008).

C. albicans posee la capacidad de crecer también en forma de filamentos, una morfología que se caracteriza por un crecimiento apical continuo y la inhibición de la separación celular. Estas propiedades permiten la formación de largos filamentos en los que los distintos compartimientos se mantienen unidos por el septo. La inhibición de la separación celular depende de la modificación en la dinámica del anillo de septinas y de la acción de la ciclina especifica de hifas Hgc1 (GonzálezNovo et al., 2008; Zheng et al., 2004). Como ya se comentó en la Introducción, los anillos de septinas presentan diferencias entre levaduras e hifas pues en estas últimas está en un estado especifico de hifas ("Hyphae-Specific State"). El mantenimiento de dicho estado depende de la la septina Sep7 y de la quinasa Hgc1, lo que resulta en una alta tasa de intercambio de Cdc10 entre el anillo y el citoplasma y en la inhibición de la separación celular en hifas (González-Novo et al., 2008). Además, la actividad del complejo Cdc28-Hgc1 está implicada en prevenir la activación de las dianas de Ace2 promoviendo la asociación del factor de transcripción Efg1 a sus promotores (Wang, et al., 2009).

En el capitulo anterior se mostraron evidencias de que Ace2 es importante durante el crecimiento hifal tanto para la persistencia de los anillos de septinas como para establecer su estado especifico de hifas. Considerando que la actividad transcripcional no es necesaria para la regulación del anillo de septinas en las hifas y que existe una segunda forma de Ace2 asociada a membranas cuyo mRNA aumenta durante el crecimiento filamentoso, se planteó la posibilidad de que fuera $A c e 2^{\mathrm{M}}$ la proteína que desempeñara un papel directo en la regulación de las septinas durante este estado morfogenético. En este capítulo se describen un conjunto de experimentos 
diseñados para analizar la función de las proteínas $A c e 2^{\mathrm{N}}$ y $A c e 2^{\mathrm{M}}$ en los distintos estados morfológicos de $C$. albicans.

\subsubsection{Funciones de $A c e 2^{\mathrm{N}}$ y $A c e 2^{\mathrm{M}}$ durante el crecimiento en forma de levaduras.}

Para analizar la función de las proteínas $A c e 2^{\mathrm{N}}$ y $A c e 2^{\mathrm{M}}$ en $C$. albicans, se utilizaron las cepas construidas previamente que contenían mutaciones puntuales en cada uno de los inicios de traducción, de tal manera que cada una expresaba únicamente una de las dos formas bajo el control de su promotor nativo. A partir de ellas, se construyeron cepas que contenían distintas septinas (Cdc10 o Sep7) marcadas con GFP para poder estudiar la estructura y dinámica de los anillos de septinas. En primer lugar, las distintas cepas se incubaron en condiciones de crecimiento levaduriforme y se analizaron sus fenotipos.

La observación microscópica de la cepa que contenía solamente $A c e 2^{\mathrm{N}}$ mostró que las células presentaban una morfología idéntica a las de las células silvestres, no apreciándose ninguna diferencia significativa entre ellas a distintas temperaturas o en distintos medios de cultivo (Fig. 37A). Por el contrario, las células de la cepa que sólo expresaba $A c e 2^{\mathrm{M}}$ presentaban una morfología similar a las del mutante nulo ace $2 \Delta / \Delta$, ya que crecían en grupos que permanecían unidos por el septo, siendo incapaces de separarse (Fig. 37A). Cuando se analizó la morfología de los anillos de septinas en estas cepas, usando tanto Sep7-GFP como Cdc10-GFP, no se apreciaron diferencias significativas en su estructura, ni en los anillos simples ni tras su división (Fig. 37B).

El hecho de que las células de la cepa ace $2 \triangle / A C E 2^{M}$ crecieran formando racimos incapaces de separarse sugiere que la forma asociada a membrana de Ace2 es incapaz de funcionar como un factor de transcripción, activando la expresión de los genes implicados en separación celular. Así, para comprobar de forma directa si Ace ${ }^{\mathrm{M}}$ presentaba actividad transcripcional, se analizó la expresión de una de sus dianas, el gen CHT3, mediante RT-PCR cuantitativa. En el mismo ensayo también se incluyó la cepa ace $2 \triangle / A C E 2^{N}$ para comparar los niveles de expresión de CHT3 con la silvestre. Los resultados del análisis cuantitativo, normalizados frente a los obtenidos a partir del gen $A D E 2$ que codifica para la fosfo-ribosil-amino-imidazol carboxilasa implicada en la ruta de biosíntesis de adenina (Tsang et al., 1997), mostraron que la expresión de $C H T 3$ en la cepa ace $2 \triangle / A C E 2^{N}$ era similar a la de cepa silvestre, mientras que en la cepa ace $2 \triangle / A C E 2^{M}$ no existía transcripción del gen marcador, similar a lo que ocurre en el mutante ace $2 \Delta / \Delta$ (Fig. 38).

Estos resultados nos indican, por tanto, que durante el crecimiento en forma de levaduras la proteína Ace $2^{\mathrm{N}}$ desempeña un papel importante, funcionando como factor de transcripción que activa la expresión de los genes implicados en separación celular. Por el contrario, $\mathrm{Ace}^{\mathrm{M}}{ }^{\mathrm{M}}$ es una forma carente de actividad transcripcional, que en esta morfología no parece desempeñar ninguna función esencial.

\subsubsection{Funciones de $A c e 2^{\mathrm{N}}$ y $A c e 2^{\mathrm{M}}$ durante el crecimiento en forma de hifas.}

Con el fin de estudiar la función de las dos formas de Ace2 durante el crecimiento hifal, se procedió a analizar los fenotipos de las cepas deficientes de cada una de ellas en un medio inductor de la filamentación. Para ello, se incubaron células en medio YEPD líquido suplementado con suero bovino, a $37^{\circ} \mathrm{C}$ durante $3-5$ horas antes de su observación morfológica. Como controles, se usaron la cepa silvestre y el mutante $a c e 2 \Delta / \Delta$.

Como primera aproximación a la caracterización de estas cepas, se decidió comprobar si la proteína Ace $2^{\mathrm{M}}$ era capaz de funcionar como activador transcripcional en estas condiciones de crecimiento. Por tanto, se analizó mediante RT-PCR cuantitativa los niveles de expresión del gen CHT3 en RNAs obtenidos de filamentos de las 


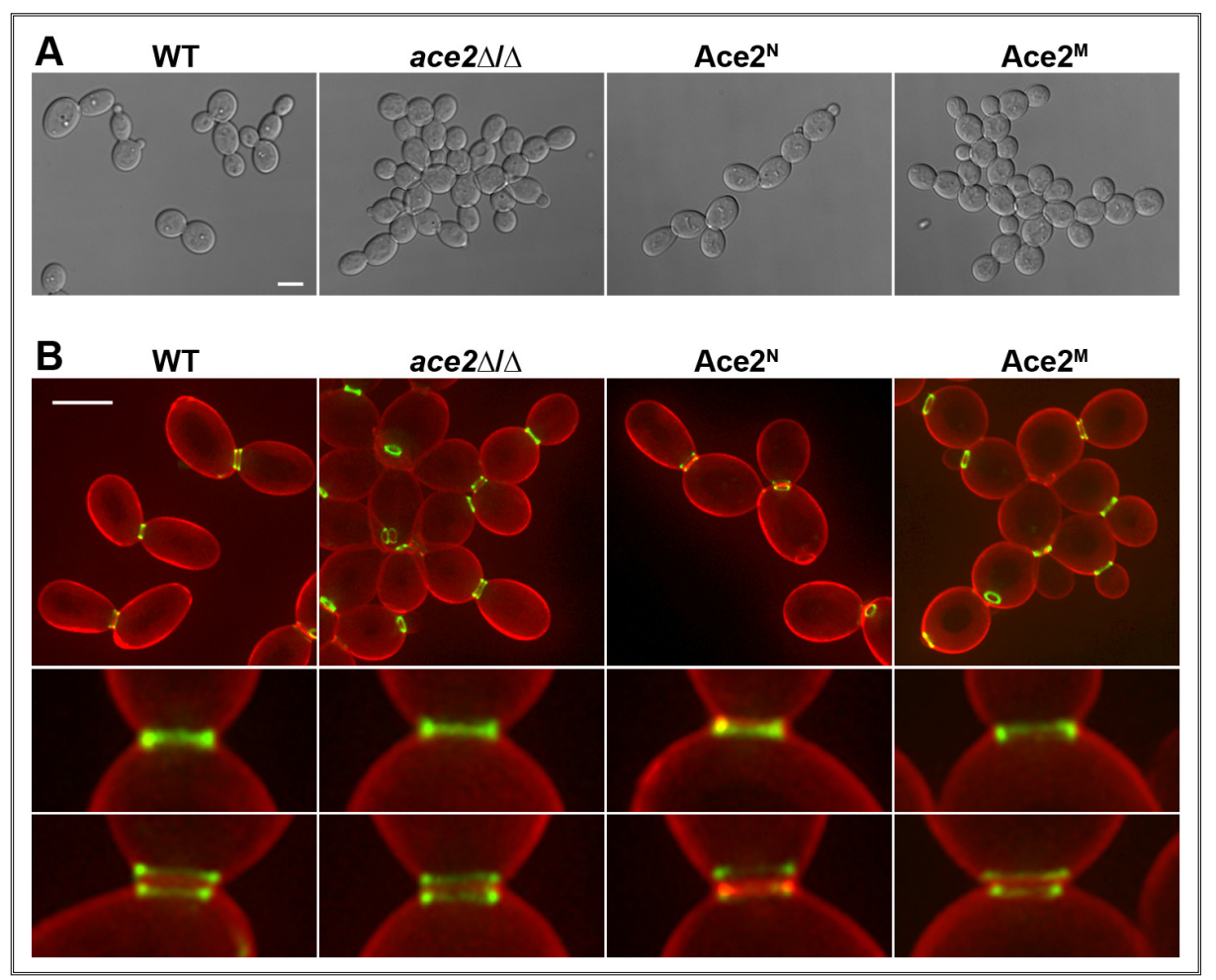

Figura 37. Fenotipo de las cepas que contienen Ace $^{\mathrm{M}}$ o Ace2 $^{\mathrm{N}}$ durante el crecimiento en forma de levaduras. A. Imágenes de contraste interferencial (DIC) de las cepas ACE2 SEP7-GFP (OL1456), ace $2 \triangle / \triangle$ SEP7-GFP (OL1457), ace $2 \triangle / A C E 2^{N}$ SEP7GFP (OL1634) y ace $2 \triangle / A C E 2^{M}$ SEP7-GFP (OL1631) durante el crecimiento levaduriforme. Barra de escala, $5 \mu \mathrm{m}$. B. Las mismas cepas fueron teñidas con calcoflúor antes de su visualización por microscopía de fluorescencia. Las imágenes son la proyección máxima de 10 planos adquiridos cada $0,4 \mu \mathrm{m}$ y muestran la fluorescencia de Sep7-GFP (verde) y la tinción de calcoflúor (rojo). En la parte inferior se muestran detalles de anillos simples y duplicados de cada cepa. Barra de escala, $5 \mu \mathrm{m}$.

cepas silvestre, ace $2 \triangle / A C E 2^{M}$ y ace $2 \triangle / A C E 2^{N}$. Como se ha mostrado previamente, se observó que la expresión de $C H T 3$ en las cepas silvestre y ace $2 \triangle / A C E 2^{N}$ era inferior en hifas comparado con las levaduras (en torno a un $50 \%$ menos), pero en ambas cepas existía expresión del gen diana (Fig. 38). Por el contrario, no se detectaba expresión de $C H T 3$ en la cepa ace $2 \triangle / A C E 2^{M}$, lo que indica que esta proteína también es incapaz de funcionar como factor de transcripción en hifas.

Los resultados mostrados en los apartados 3.1.1 y 3.1.2 indican que el factor de transcripción Ace2 desempeña un papel en la regulación del anillo de septinas durante la filamentación, aunque esta función es independiente de su actividad transcripcional. Puesto que la isoforma Ace $2^{\mathrm{M}}$ no funciona como activador transcripcional ni en levaduras ni en hifas, se planteó la posibilidad de que fuera esta forma la que controlara la dinámica de los anillos de septinas en hifas. Por ello, se decidió analizar con detalle el fenotipo de las hifas de las cepas ace $2 \triangle / A C E 2^{M}$ y ace $2 \triangle / A C E 2^{N}$ y compararlas con las cepas control ACE2 y ace $2 \Delta / \Delta$ mediante microscopía de fluorescencia. Cuando se indujo la filamentación de las cuatro cepas, se observó que todas ellas eran capaces de responder al estímulo y formar filamentos. Aparentemente, las hifas de la cepa ace $2 \triangle / A C E 2^{M}$ parecían similares a las del mutante ace $2 \Delta / \Delta$, ya que se originaban a partir de grupos células levaduriformes que no se habían separado (al carecer de la forma nuclear que actúa como factor de transcripción), mientras que las de la estirpe ace $2 \triangle / A C E 2^{N}$ se originaban a partir de células individuales más similares a las del silvestre (Fig. 39). Sin embargo, un análisis más detallado reveló una serie de defectos morfológicos en las hifas de la cepa carente de la forma de membrana, que incluyen diferencias en el posicionamiento del primer septo,

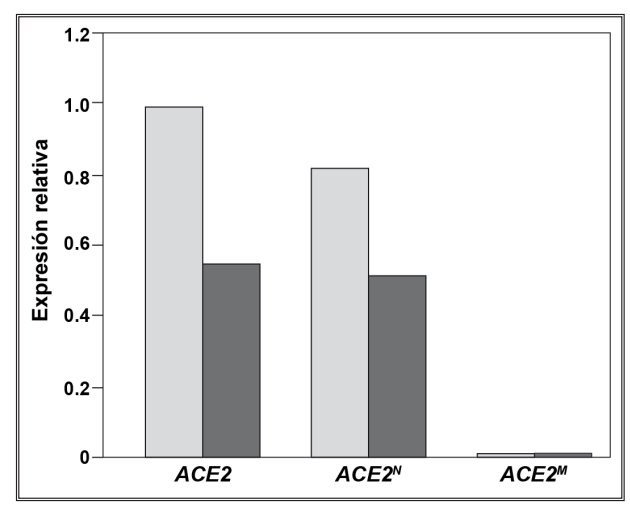

Figura 38. Ace $2^{\mathrm{M}}$ carece de actividad transcripcional. Niveles de expresión de $C H T 3$ en las cepas silvestre (OL1202), ace $\triangle \triangle / A C E 2^{N}$ (OL1598) y ace2 $\triangle / A C E 2^{M}$ (OL1597), analizados mediante PCR cuantitativa. Se analizó mRNA obtenido de células creciendo en forma de levaduras (gris claro) o tras la inducción de la filamentación (gris oscuro). Los valores fueron normalizados con los obtenidos de la expresión del gen $A D E 2$. 
cambios en la organización y dinámica o activación de la separación celular que serán descritos con más detalle en los siguientes apartados.

\subsubsection{Ace ${ }^{\mathrm{M}}$ es necesario para el correcto posicionamiento del primer septo en los filamentos de C. albicans.}

Como se comentó en la Introducción, la posición de los septos en las hifas está determinada por el punto de la membrana lateral del filamento en el que se quedan ancladas las septinas que inicialmente se encuentran en el ápice de la hifa. Cuando ésta alcanza una longitud determinada, las septinas apicales quedan unidas a la membrana lateral del filamento y rápidamente se organizan en un anillo, que marcará la posición del septo durante citoquinesis (Sudbery, 2011). Con el objetivo de realizar la caracterización fenotípica de las cepas en estudio, se analizó con detalle la morfología de sus filamentos después de 3 horas de inducción mediante microscopia de fluorescencia. Las primeras observaciones parecían mostrar que en los filamentos de la cepa ace $2 \triangle / A C E 2^{N}$, el primer septo parecía posicionarse más alejado del cuerpo celular que en la cepa silvestre (Fig. 40A).

Para confirmar estos resultados, se cuantificó la distancia entre el primer septo y el cuerpo de la hifa en las cuatro cepas, midiendo al menos 50 hifas diferentes en cada una. En la cepa silvestre, la distancia media entre el cuerpo y el primer septo era de $8,99 \pm 0,3 \mu \mathrm{m}(\mathrm{N}=113)$, similar al promedio obtenido para la cepa ace $2 \Delta / A C E 2^{M}(9,92$ $\pm 0,49 ; N=67)$. Por el contrario, tanto en el mutante ace $\Delta / \Delta$ como en la cepa ace $2 \Delta / A C E 2^{N}$ esta distancia era significativamente superior: $14,24 \pm 0,33(\mathrm{~N}=86)$ para el mutante nulo y $17,12 \pm 0,34(\mathrm{~N}=77)$ para la cepa que solo tiene la forma nuclear y carece de la de membrana (Fig. 40B). El análisis estadístico mostró que estas diferencias son estadísticamente significativas ( $t$ test: $P$ value $<0,0001$ ). Por tanto, estos resultados sugieren que la forma de Ace2 asociada a membranas desempeña un papel importante en el proceso que determina la localización

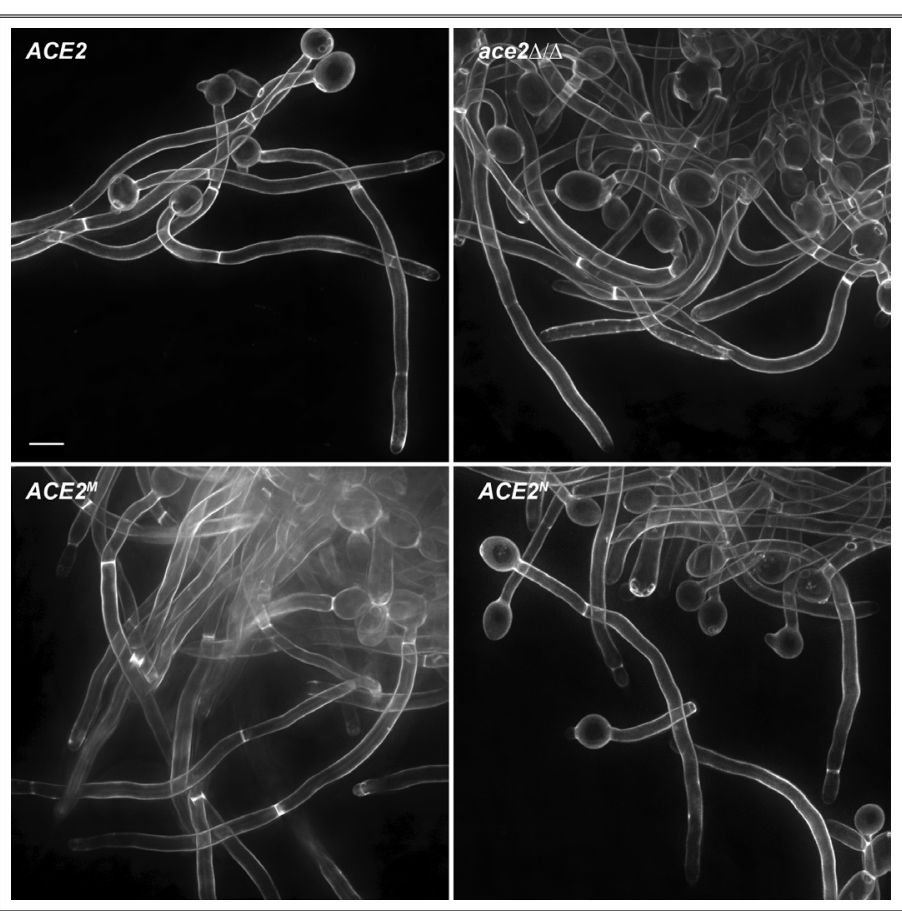

Figura 39. Fenotipo de las cepas $A c e 2^{\mathrm{M}}$ y $A c e 2^{\mathrm{N}}$ durante el crecimiento en forma de hifas. Las cepas ACE2 (OL1202), ace $2 \Delta / \Delta$ (OL1451), ace $2 \Delta / A C E 2^{N}$ (OL1634) y ace $2 \triangle / A C E 2^{M}$ (OL1631) se incubaron en condiciones de inducción de filamentos durante 3 horas antes de teñirlas con calcoflúor. Las imágenes son la proyección máxima de 10 planos adquiridos cada $0,4 \mu \mathrm{m}$ y muestran la fluorescencia de calcoflúor. Barra de escala, $5 \mu \mathrm{m}$. y posicionamiento del primer septo en la hifas de C. albicans.

\subsubsection{Ace $2^{\mathrm{M}}$ se necesita para el correcto} ensamblaje del anillo de septinas en las hifas de $C$. albicans.

Mientras se realizaba la cuantificación de la distancia entre el cuerpo y el primer septo, también se observó que en la cepa carente de la forma de membrana de Ace2 en algunos casos los septos eran anormales, como el que se muestra en la Fig. 40A. Puesto que la posición y estructura de los septos depende de la organización del anillo de septinas, era posible que los anillos de septinas también tuvieran defectos en esta cepa. Por ello, se decidió analizar directamente esta estructura en las cuatro cepas bajo estudio, utilizando cepas en las que Sep7 había sido marcado con GFP. De nuevo, se indujo la filamentación en las cepas marcadas y se 
analizó la estructura de los anillos de septinas por microscopía de fluorescencia tras 2-3 de incubación en medio con suero.

Este análisis mostró que en la cepa carente de la proteína nuclear (ace2 $\triangle / A C E 2^{M}$ ) los anillos de septinas, tanto simples como dobles, estaban bien organizados y eran similares en apariencia a los observados en la cepa silvestre (Fig. 41). Por el contrario, en la cepa $a c e 2 \Delta / \Delta$ y la cepa carente de la proteína de membrana $\left(a c e 2 \Delta / A C E 2^{N}\right)$ los anillos de septinas presentaban distintos defectos morfológicos, aunque los defectos parecían más severos en ace $2 \Delta / A C E 2^{N}$ que en ace $2 \Delta / \Delta$. En la Figura 42 se muestran detalles de los distintos defectos morfológicos observados en la cepa ace $2 \triangle / A C E 2^{N}$, como septinas dispersas en la membrana que no llegan a formar un anillo o anillos no cerrados que forman una espiral en el tubo germinativo. Algunos de estos defectos también son observables en la cepa ace $2 \Delta / \Delta$, aunque con una frecuencia menor que en la estirpe carente de la proteína de membrana. Resultados similares se obtuvieron cuando se analizó la localización de Cdc10-GFP en estas cepas, lo que indica que los defectos no son específicos de Sep7, sino que afectan a todo el anillo de septinas. Por tanto, estas observaciones apoyan la hipótesis de que la forma de membrana de Ace2 puede estar controlando, de forma directa o indirecta, el ensamblaje del anillo de septinas.

\subsubsection{Ace ${ }^{\mathrm{M}}$ es necesaria para convertir los anillos de septinas al estado específico de hifas.}

Como se ha comentado en la Introducción, la inducción de crecimiento hifal resulta en la conversión del anillo de septinas de levadura a un estado específico de hifas, el cual se caracteriza por la presencia de un núcleo estable de septinas (compuesto por Sep7, Cdc3 y Cdc12) y un alto intercambio de Cdc10 y Cdc11 entre el anillo y el citoplasma (González-Novo, et al., 2008). Teniendo en cuenta que los anillos de septinas de la cepa carente de la proteína $\mathrm{Ace} \mathrm{2}^{\mathrm{M}}$ presentan defectos importantes en su estructura, se decidió analizar la dinámica de Cdc10 mediante ensayos de FRAP de las cepas ace $2 \triangle / A C E 2^{\mathrm{N}}$ y $a c e 2 \triangle / A C E 2^{\mathrm{M}}$. Para ello se usaron las cepas $a c e 2 \triangle / A C E 2^{\mathrm{N}}$ CDC10-GFP y ace $\triangle / A C E 2^{\mathrm{M}}$ CDC10-GFP, las cuales se incubaron en presencia de suero fetal bovino al $10 \%$ a $37^{\circ} \mathrm{C}$ para inducir la filamentación durante 2 horas. Como se ha descrito anteriormente, para analizar el intercambio de Cdc10 con el citoplasma se eliminaba la fluorescencia del anillo completo mediante iluminación con el laser del microscopio confocal y se analizaba su recuperación a lo largo del tiempo. Cuando se analizó la recuperación de la fluorescencia de Cdc10, se comprobó que el mutante carente de la forma nuclear (la cepa ace $2 \Delta / A C E 2^{\mathrm{M}}$ ) presentaba una dinámica similar a la de la cepa silvestre, ya que entre los 120 y 160 minutos alcanzaban un valor en torno al $40 \%$ de la fluorescencia inicial (Fig. 43). Por el contrario, la cepa que carece de la forma de membrana

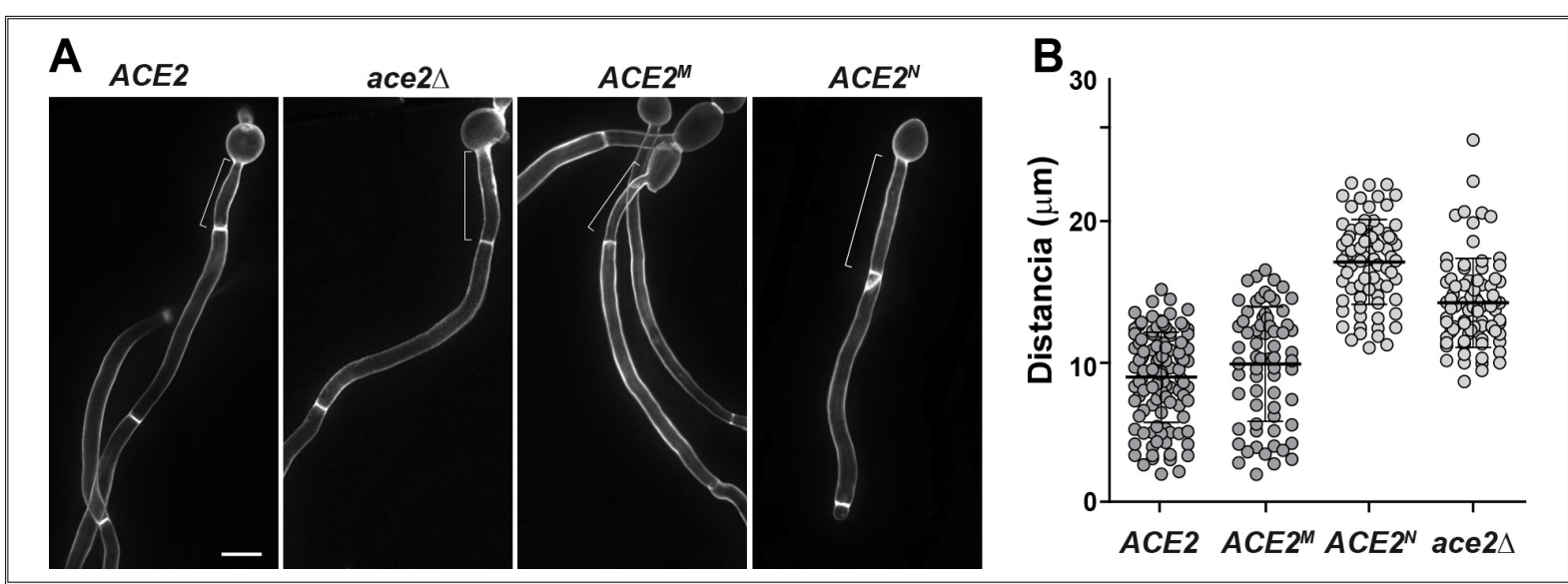

Figura 40. Ace2 ${ }^{\mathrm{M}}$ es necesario para el correcto posicionamiento del primer septo. A. Microscopía de fluorescencia de las cepas ACE2 (BWP17), ace $2 \Delta / A C E 2^{M}\left(\mathrm{OL1597)}\right.$, ace $2 \Delta / A C E 2^{N}$ (OL1598) y ace $2 \Delta / \Delta$ (OL1453) teñidas con calcoflúor. Los corchetes indican la distancia entre el cuerpo de la hifa y el primer septo. Barra de escala, $5 \mu \mathrm{m}$. B. Diagrama de dispersión de las medidas de la distancia entre el primer septo y el cuerpo de la hifa en las mismas cepas. Se indica la media y la desviación estandar. 


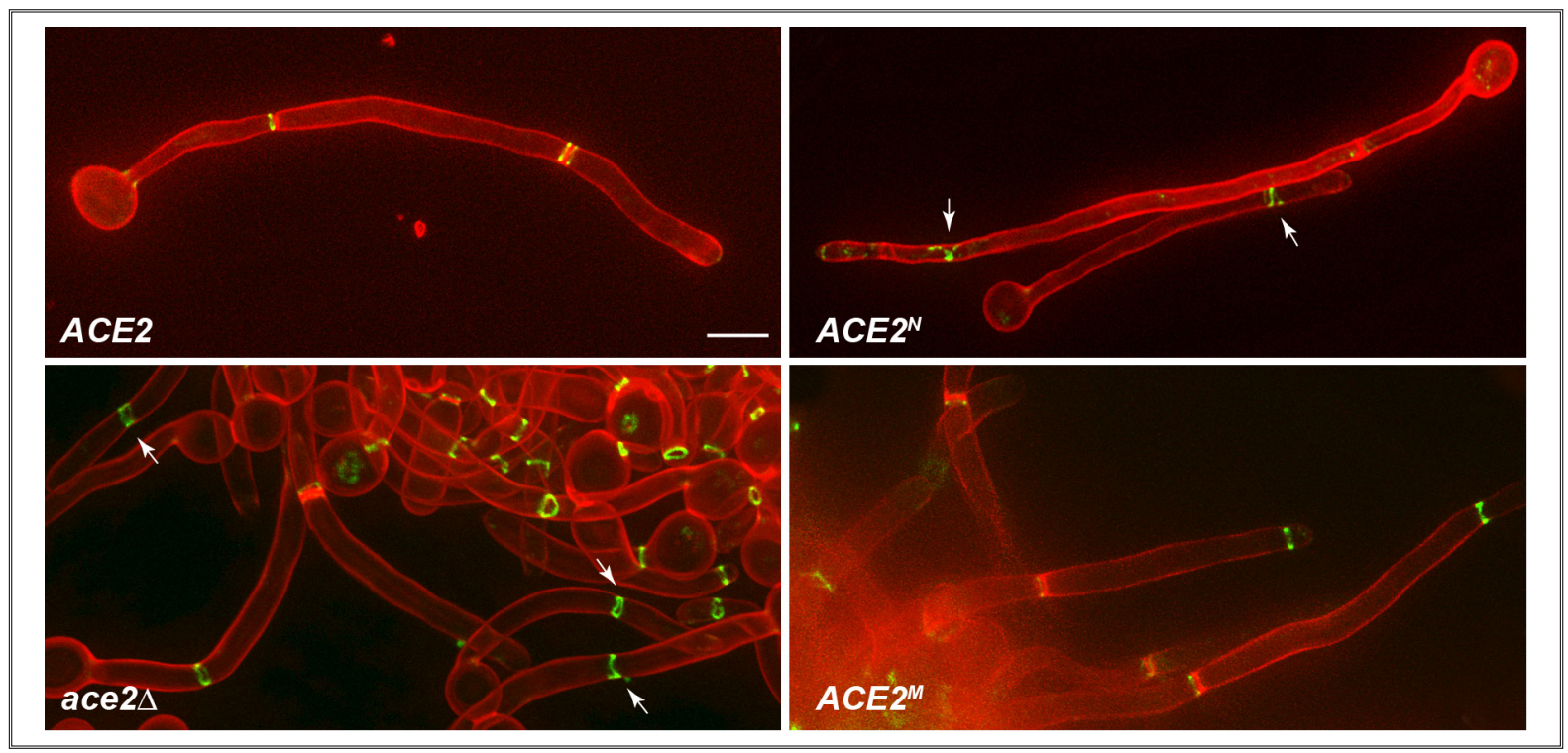

Figura 41. Anillos de septinas de las cepas $A c e 2^{\mathrm{M}}$ y $A c e 2^{\mathrm{N}}$ en hifas. Análisis por microscopía de fluorescencia de la septina Sep7 en las cepas

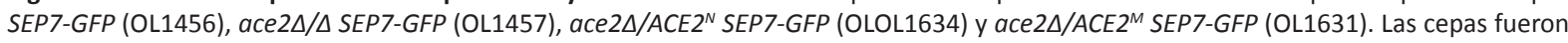
teñidas con calcoflúor antes de su visualización. Las imágenes son la proyección máxima de 10 planos adquiridos cada 0,4 $\mu$ m y muestran la fluorescencia de Sep7-GFP (verde) y la tinción de calcoflúor (rojo). Barra de escala, $5 \mu \mathrm{m}$.

$\left(\right.$ ace $\left.2 \Delta / A C E 2^{N}\right)$ presentaba un patrón de recuperación similar al observado en el mutante ace $2 \Delta / \Delta$ descrito en la Figura 20, ya que no se observaba recuperación de la fluorescencia de la septina Cdc10 incluso a tiempos más largos. Estos resultados en conjunto con los descritos en el apartado 3.2.4, indican que Ace $2^{\mathrm{M}}$ es la forma de Ace2 que regula la conversión del anillo de septinas al estado específico de hifas en C. albicans.

\subsubsection{Ace $2^{\mathrm{M}}$ es esencial para inhibir la separación de los compartimentos celulares de las hifas.}

Estudios previos realizados en el laboratorio han demostrado que existe una correlación directa entre la dinámica del anillo de septinas y la inhibición de la separación celular en las hifas de C. albicans, de tal manera que cuando el intercambio de la septina Cdc10 con el citoplasma no tiene lugar se activa la separación de los compartimentos de las hifas, como ocurre en el mutante sep $7 \Delta / \Delta$ (González-Novo et al., 2008). Si esta correlación ocurre en todos los casos, cabía esperar que en las hifas del mutante carente de la forma de membrana de Ace2, en la que la dinámica del anillo de septinas es deficiente en hifas, también se activara la separación de los distintos compartimentos mediada por la activación de la expresión de enzimas hidrolíticas como la quitinasa Cht3 y la endo-glucanasa Eng1.

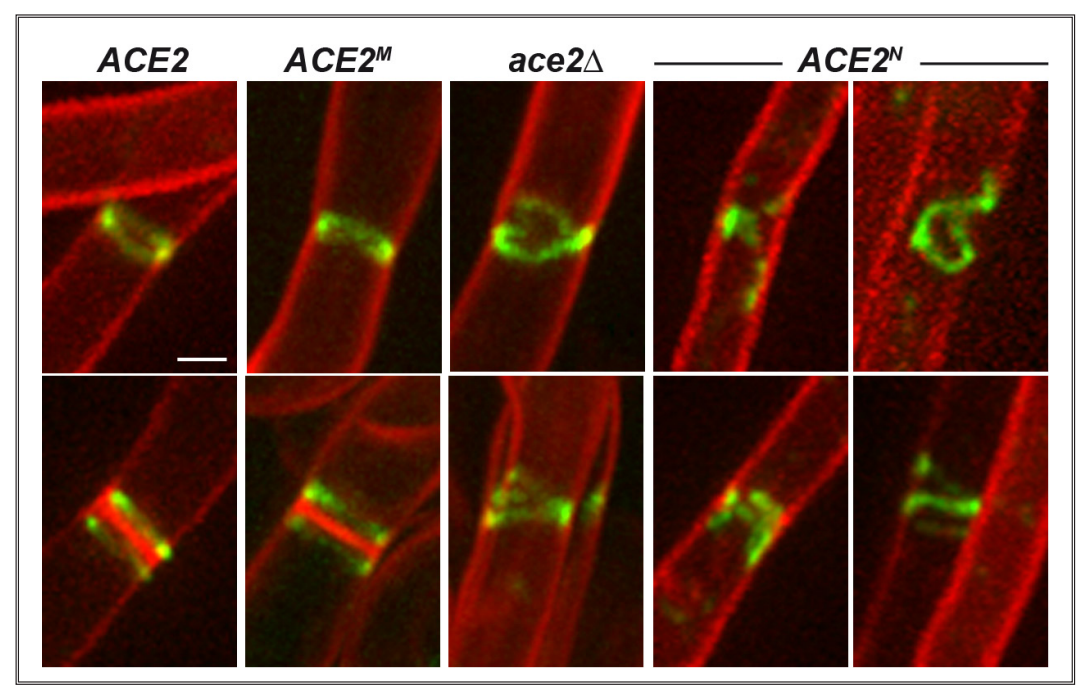

Figura 42. Estructura de los anillos de septinas durante la filamentación. Detalles de anillos de septinas en las cuatro cepas usadas en la Figura 37. Los recuadros representa la ampliación del anillo de septinas. Las imágenes muestran la fluorescencia de Sep7-GFP (verde) y la tinción de calcoflúor (rojo). Barra de escala, $1 \mu \mathrm{m}$. 
Para analizar si esta idea era correcta, se analizó si la separación celular estaba activada durante el crecimiento hifal en las distintas cepas en estudio. Para ello, la cepa silvestre y los mutantes ace $2 \triangle / A C E 2^{\mathrm{M}}$ y $a c e 2 \triangle / A C E 2^{\mathrm{N}}$ se incubaron en presencia de suero fetal bovino al $10 \%$ a $37^{\circ} \mathrm{C}$ durante $3-4$ horas para inducir la filamentación y posteriormente se observaron al microscopio. La observación de estas cepas mostró que en el mutante carente de la proteína de membrana (ace $2 \triangle / A C E 2^{N}$ ) el número de filamentos aislados (sin cuerpo celular unido) y de cuerpos celulares separados era superior al observado en las cepas silvestre, ace $2 \Delta / A C E 2^{\mathrm{M}}$ y ace $2 \Delta / \Delta$ (Fig. $\left.44 \mathrm{~A}\right)$, lo que indicaba que la separación celular estaba activada en esa cepa.

Para tener una idea numérica de este defecto en cada una de las cepas, se decidió cuantificar de hifas en las que se había activado la separación celular. La cuantificación del número de compartimentos del filamento aislados nos daría un valor incorrecto de la separación, ya que varios compartimentos podían provenir de la misma hifa, por lo que se decidió contar el número de cuerpos celulares que todavía permanecían unidos a un filamento frente a los que estaban separados o en proceso de separación (Fig. 44B). Los resultados obtenidos indicaron que mientras que en la cepa silvestre y en el mutante ace $2 \triangle / A C E 2^{N}$ el porcentaje de separación era inferior al $5 \%$, en la cepa carente de la forma de membrana este valor era unas 5 veces superior, llegando hasta el $25 \%$ (Fig. 44C). El mutante ace $2 \Delta / \Delta$ no ha sido representado en la gráfica ya que al carecer de Ace2 es no es capaz de activar la separación celular ni en hifas ni en levaduras.

En resumen, todos los resultados descritos en los últimos apartados, indican que la forma de membrana de la proeteína Ace2 es necesaria para regular la dinámica del anillo de septinas, y por tanto, para inhibir la separación celular durante el crecimiento hifal de C. albicans.

\subsubsection{La inserción ectópica de Ace $2^{\mathrm{M}}$ revierte el fenotipo de separación celular.}

Resulta sorprendente el hecho de que un gen que codifica para un factor de transcripción, codifique a su vez para otra proteína que difiere no solamente en su estructura, sino también en su localización y función. Teniendo en cuenta que el establecimiento y mantenimiento del estado especifico de hifas del anillo de septinas es un proceso trascendental en la morfogénesis de $C$. albicans, la identificación y caracterización de proteínas que lo regulen resulta de crucial importancia. Los resultados descritos en los apartados anteriores sugieren que en $C$. albicans

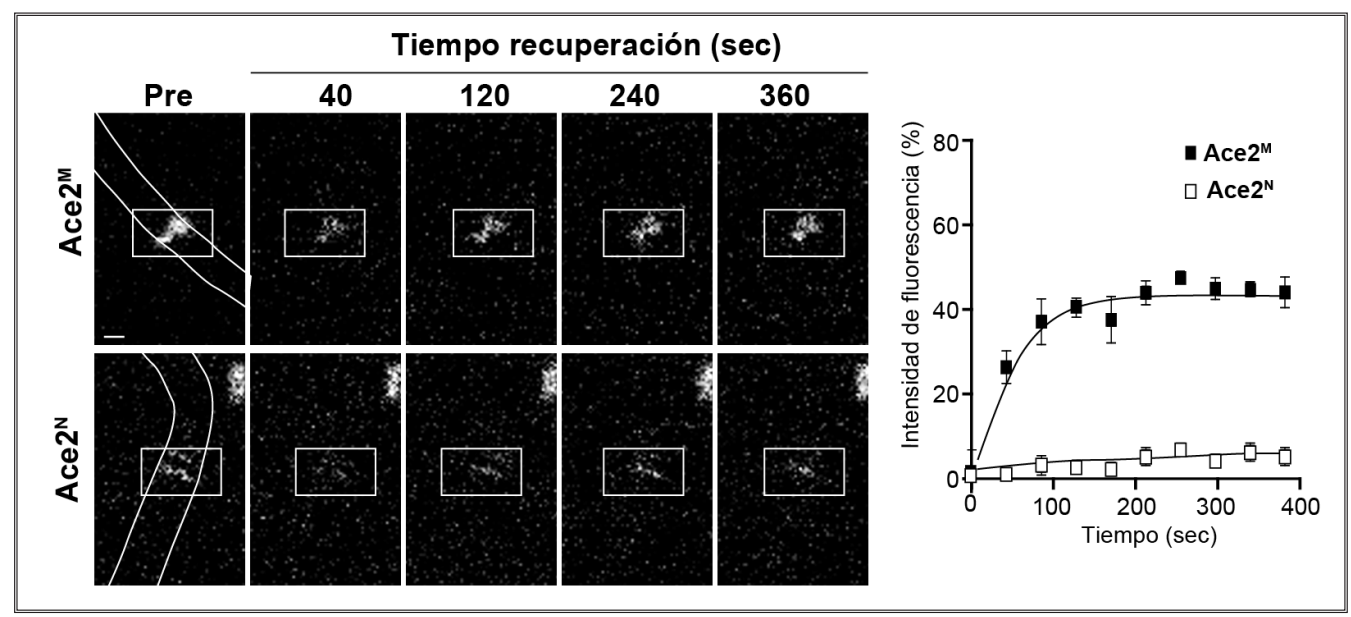

Figura 43. Ace $2^{\mathrm{M}}$ es esencial para la dinámica de Cdc10 durante el crecimiento hifal de $C$. albicans. Dinámica de Cdc10 en las cepas ace2 $\triangle / A C E 2^{N}$ CDC10-GFP (OL1659) y ace $2 \triangle / A C E 2^{M}$ CDC10-GFP (OL1662). Anillos completos fueron irradiados con el laser de un microscopio confocal a máxima potencia para eliminar la fluorescencia y posteriormente se tomaron imágenes a los tiempos indicados en la figura para analizar la recuperación de la fluorescencia. La gráfica muestra la cuantificación de la fluorescencia en cada cepa y es la media de tres anillos diferentes. Las barras de error indican la desviación estándar. Barra de escala, $1 \mu \mathrm{m}$. 
la forma de membrana de Ace2 es una de las proteínas reguladoras del estado específico de hifas del anillo de septinas. Para confirmar que los defectos observados en la cepa ace $2 \triangle / A C E 2^{N}$ eran debidos específicamente a la ausencia de la forma de membrana, se decidió construir una cepa derivada de ella en la que la proteína de membrana se insertó de forma ectópica en un locus heterólogo bajo el control de un promotor regulable. Teniendo en cuenta que en C. albicans no se han desarrollado hasta ahora estrategias de expresión episomal, el locus RP10 se presenta como una excelente estrategia para superar este inconveniente. Ello se debe a tres razones fundamentales: primero, existen dos loci en el genoma, por lo que la disrupción de uno de sus alelos no tiene mayores efectos en el crecimiento de la célula; segundo, debido a su alta tasa de expresión, la integración por recombinación homóloga es muy eficiente, lo que se ve reflejado en el número de transformantes; y por último, la integración cromosomal en un locus muy expresado, facilita la expresión de los genes integrados en él (Care et al., 1999).

Así, a partir de la cepa ace $2 \triangle / A C E 2^{N}$ se procedió a integrar la secuencia codificante de Ace $2^{\mathrm{M}}$ bajo el control del promotor MET3 en el locus RP10. Además, para confirmar que la actividad transcripcional de Ace2 no era necesaria para la función de la forma de membrana, se construyo otra cepa similar en la que se insertó la secuencia codificante de la proteína $A c e 2^{\mathrm{M}}$ sin la región correspondiente a los dedos de Zinc (estructura de las construcciones en la Figura 45A). Una vez comprobado que la disrupción de uno de los alelos de RP10 no tenía defecto importante en el crecimiento de las células, estas cepas se incubaron en condiciones de inducción de la filamentación durante 4 horas junto con la cepa silvestre y el mutante ace $2 \triangle / A C E 2^{M}$. Se realizaron fotografías en el microscopio de fluorescencia para cuantificar los porcentajes de separación en hifas. Se observó que la reinserción tanto de la forma de membrana completa (Ace ${ }^{\mathrm{M}}$ ) como de la forma de membrana sin los dedos de zinc (Ace ${ }^{\mathrm{M}}-\Delta \mathrm{Zn}$ ) reducía el porcentaje de cuerpos separados hasta niveles similares a los observados en la cepa silvestre (Fig. 45B). Este resultado indica que los defectos observados en el mutante ace $2 \triangle / A C E 2^{N}$ se deben únicamente a la ausencia de $A c e 2^{\mathrm{M}}$, ya que su reinserción en un locus ectópico restaura el fenotipo silvestre, y que los dedos de Zn no son necesarios para la función de la proteína de membrana durante la filamentación de c. albicans.

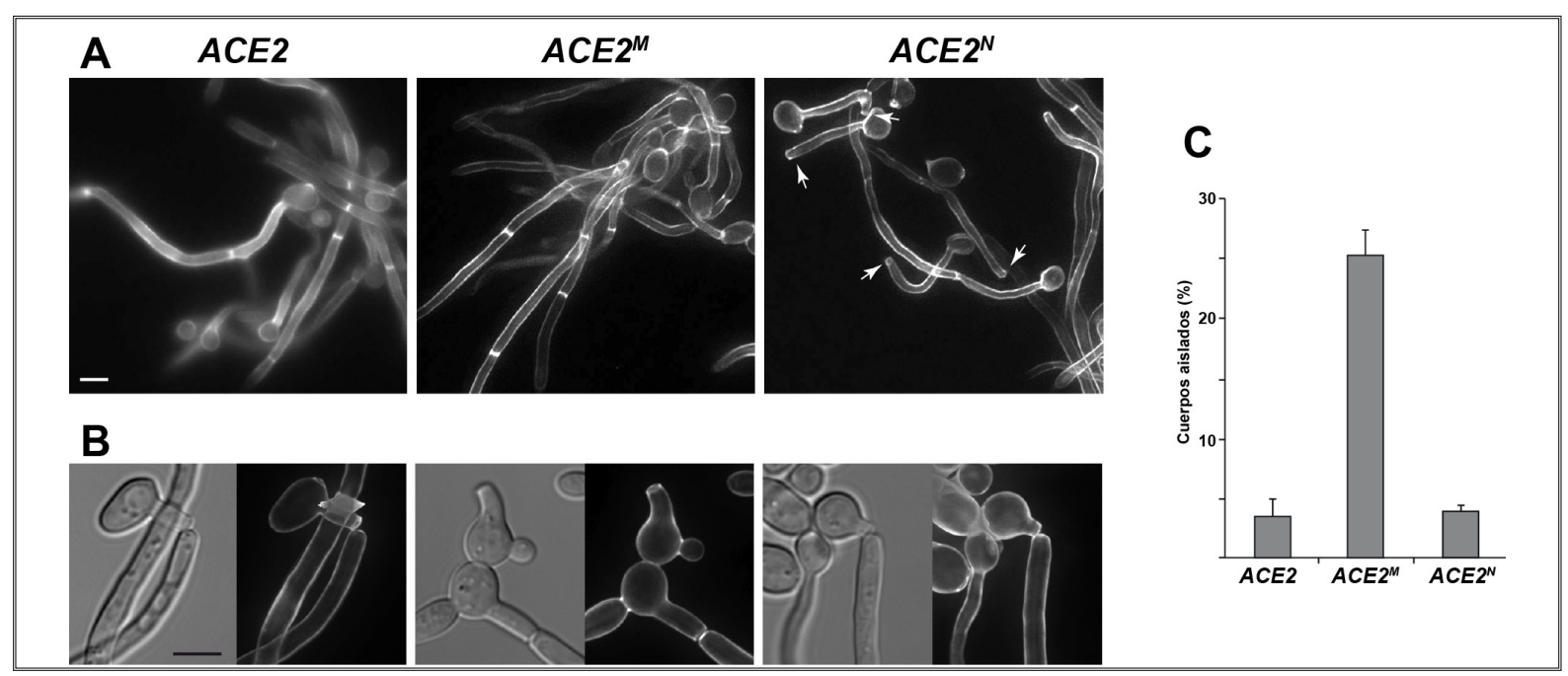

Figura 44. Las hifas del mutante $A c e 2^{\mathrm{N}}$ se separan después de la citoquinesis. A. Microscopía de fluorescencia de filamentos de las cepas silvestre (BWP17), ace2 $\triangle / A C E 2^{N}$ (OL1598) y ace2 $\triangle / A C E 2^{M}$ (OL1597), tras 3,5 horas de inducción de la filamentación en presencia de suero fetal bovino al $10 \%$ a $37^{\circ} \mathrm{C}$. Barra de escala, $5 \mu \mathrm{m}$. B. Ejemplos de cuerpos celulares separados o en separación observados en la cepa ace $2 \Delta /$ $A C E 2^{N}$. C. Cuantificación del porcentaje de cuerpos separados observados en filamentos de la cepa silvestre (BWP17) y los mutantes ace2 $\triangle$ / $A C E 2^{N}$ y ace $2 \triangle / A C E 2^{M}$ tras 3,5 horas de inducción de la filamentación. Los datos son la media de 2 experimentos individuales, en los que se indica la desviación estándar. 


\subsubsection{Análisis de las regiones necesarias para la función de $A c e 2^{\mathrm{M}}$ durante el crecimiento hifal de $C$. albicans.}

En S. cerevisiae se ha realizado un análisis de los diferentes dominios del factor de transcripción Ace2 y se describieron 6 regiones o subdominios que desempeñan diferentes funciones a nivel subcelular (McBride et al., 1999). Así, en la región A (aminoácidos 1-200) se encuentran las señales de localización y exporte nuclea (NES)r, así como dos sitios de fosforilación de Cbk1-Mob2; la región B (aminoácidos 201-301) parece ser necesaria para la interacción con Cbk1-Mob2, y junto con la región A es importante para la localización especifica del factor de transcripción en el núcleo de la célula hija; la zona C (aminoácidos 302-469) es necesaria para la activación transcripcional de las dianas, como CTS1; la zona D (aminoácidos 470-577) no presenta función conocida, aunque contiene múltiples sitios de fosforilación por CDKs; la región E (aminoácidos 578-692) contiene los dedos de zinc necesarios para su actividad como factor de transcripción; y por último, en la región $\mathrm{F}$ (aminoácidos 693-770) existe otra señal de localización nuclear.

En C. albicans no se ha realizado un análisis similar, por lo que no se conoce si existen diferentes regiones o dominios con funciones especializadas. Para analizar si existía una conservación en esta estructura modular, se realizó un alineamiento de las proteínas Ace2 de $S$. cerevisiae y $C$. albicans. A pesar de que el alineamiento global no es excesivamente bueno $(24,5 \%$ de identidad y $34,6 \%$ de similitud), es posible observar que al menos algunas de estas regiones se mantienen conservadas en ambas proteínas. Este es el caso de las regiones A $(31,1 \%$ de similitud), B $(47,3 \%)$ y $E(60,8 \%)$, que presentan la mayor similitud entre ambas proteínas y corresponden a las regiones que regulan la exportación nuclear, interacción con Cbk1 y los dedos de $\mathrm{Zn}$, respectivamente (Fig. 46). Por el contrario, las regiones C, D y $F$ son altamente divergentes, siendo sus porcentajes de similitud inferiores al $20 \%$, por lo que podrían ser regiones de la proteína que desempeñan funciones diferentes en cada organismo. Así mismo, cabe destacar que la división de la región central de Ace2 en $C$. albicans en los dominios C y D podría ser arbitraria y formar una única unidad funcional en lugar de dos separadas, ya que una peculiaridad de estas dos regiones es que ambas poseen un alto contenido en Gln

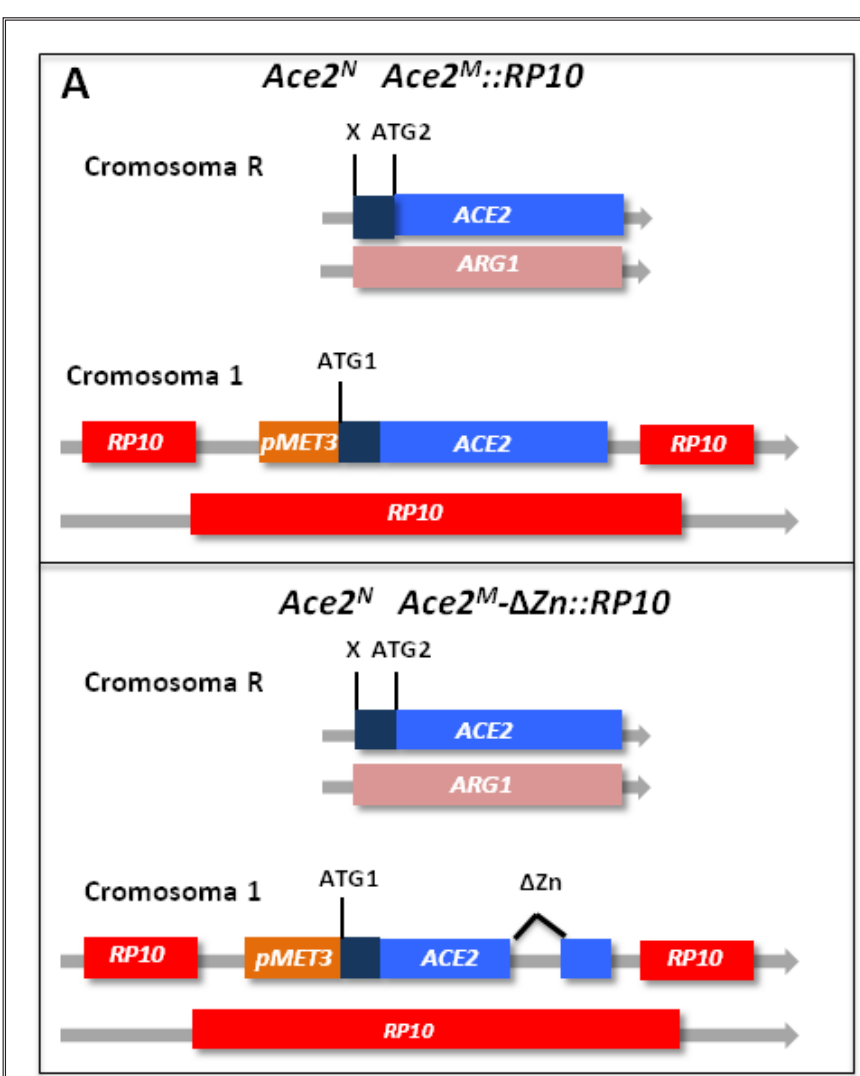

B

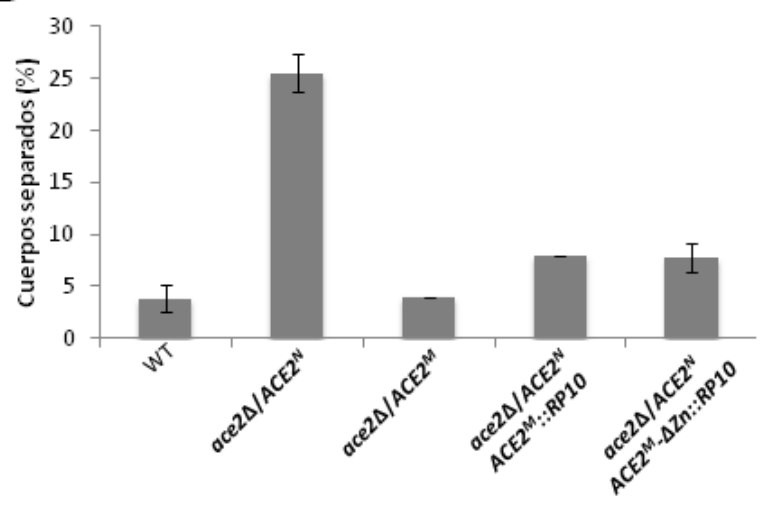

Figura 45. La activación de la separación celular del mutante $A c e 2^{\mathrm{N}}$ se debe a la ausencia de la forma de membrana. A. Esquema de las construcciones insertadas en el locus RP10. B. Cuantificación del porcentaje de cuerpos separados observados en filamentos de la cepa silvestre (BWP17) y los mutantes ace $2 \triangle / A C E 2^{N}$ (OL1598), ace2 $\triangle / A C E 2^{M}$ (OL1597) ace2 $/$ ACE2 $^{N}$ ACE2 $^{M}:: R P 10$ (OL1171) y ace $2 \triangle / A C E 2^{N} A C E 2^{M}-\triangle Z n:: R P 10$ (OL1191) tras 3,5 horas de inducción de la filamentación. Los datos son la media de 2 experimentos individuales, en los que se indica la desviación estándar. 


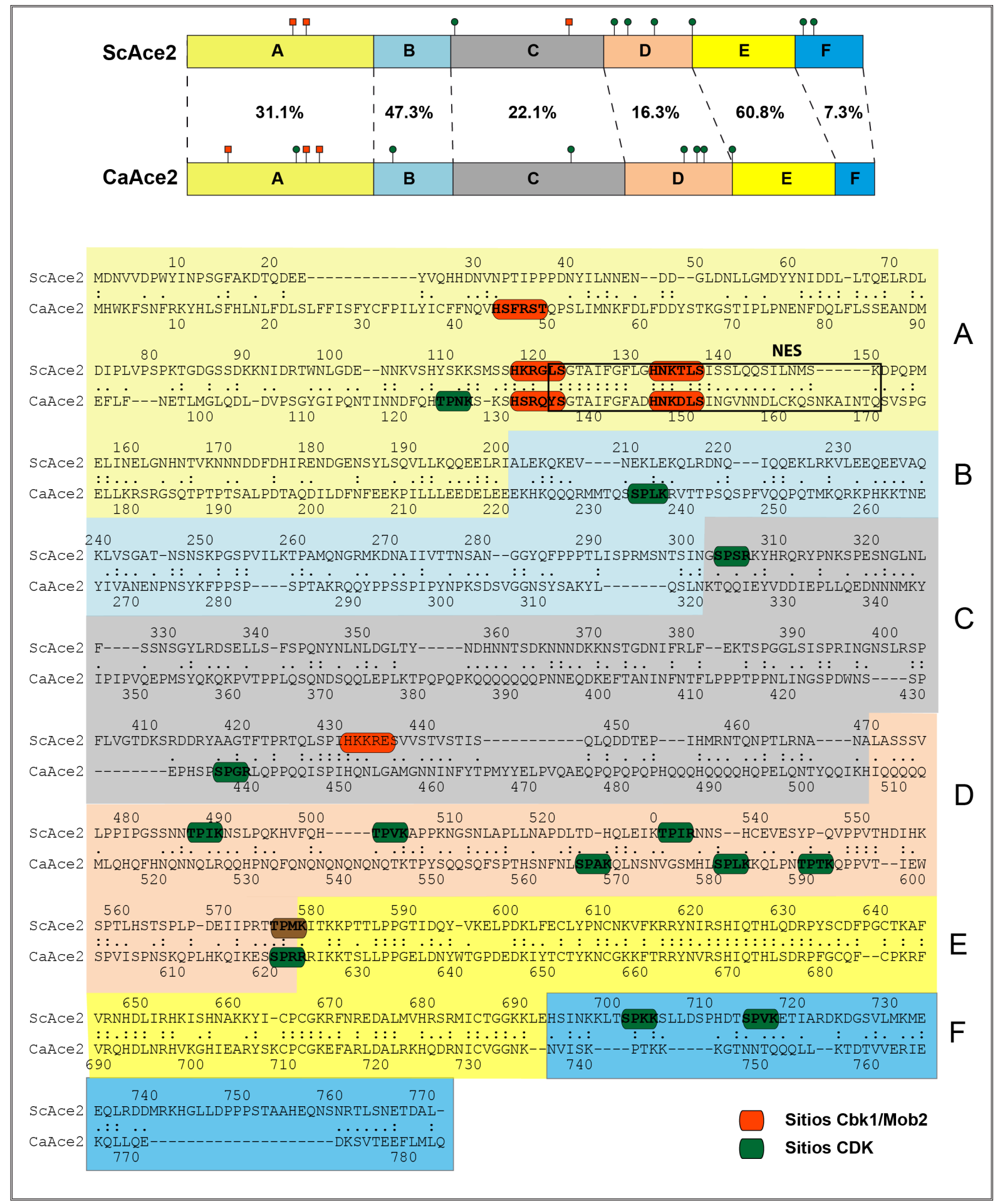

Figura 46. Comparación de las secuencias de Ace2 en C. albicans y S. cerevisiae. En la parte superior se muestra un esquema con las regiones identificadas en ScAce2 y su posible correspondencia con la secuencia de Ace2 en C. albicans. Se indican los porcentajes de similitud en cada región. La parte inferior muestra el alineamiento de las secuencias de ambas proteínas, en las que se han marcado las distintas regiones de ScAce2. Los posibles sitios de fosforilación se indican con cajas rojas (Cbk1-Mob2) o verdes (sitios CDK completos).

( 21,5 y $22 \%$, respectivamente), Pro $(17,2 \%$ y $11.1 \%)$ y Asn $(9,1 \%$ y $12,8 \%)$ y forman una región con estructura secundaria no regular ("Non-Regular Secondary Structure" o NORS).

Para tratar de profundizar en el estudio del mecanismo por el que $A c e 2^{\mathrm{M}}$ regula al anillo de septinas en hifas, se decidió hacer un análisis de las regiones de esta proteína necesarias para esta función. Para ello, se construyeron 
distintos truncamientos de $\mathrm{Ace} 2^{\mathrm{M}}$ en los que se eliminaban progresivamente distintas regiones de la proteína (Fig. 47). Para estas construcciones se utilizó el mismo sistema de integración en el locus RP10 descrito en el apartado anterior, y todas ellas se integraron en la cepa heterozigótica carente de $A c e 2^{\mathrm{M}}\left(\operatorname{ace} 2 \Delta / A C E 2^{\mathrm{N}}\right)$. La expresión de estas versiones de Ace $2^{\mathrm{M}}$ fue comprobada mediante Western blot. Una vez comprobado que las distintas versiones de la proteína $\mathrm{Ace} 2^{\mathrm{M}}$ se expresaban, las cepas se incubaron en condiciones de inducción de la filamentación durante 3,5 horas, se tiñeron con calcoflúor y se observaron al microscopio para determinar el porcentaje de cuerpos separados. Los resultados obtenidos mostraron que los porcentajes de separación celular en hifas de la construcción que eliminaba las regiones $E$ y $F\left(A c e 2^{M}-A B C D\right)$ era similar a la obtenida previamente cuando se insertaba en el locus $R P 10$ la proteína $A c e 2^{\mathrm{M}} \sin$ los dedos de $\mathrm{Zn}$ (Ace $2^{\mathrm{M}}-\triangle \mathrm{Zn}$ ), y un porcentaje similar se observó cuando se analizó la cepa que contenía únicamente los dominios $A$ y B (Ace ${ }^{M}$-AB) (Fig. 47). Sin embargo, la cepa que expresaba sólo el dominio $A\left(A c e 2^{M}-A\right)$ era incapaz de complementar el defecto. Estos resultados parecen indicar que la región $B$ es necesaria para la función de $A c e 2^{\mathrm{M}}$ en la regulación de la separación celular de las hifas. Para comprobar esta observación, se construyó otra versión de la proteína en la que se eliminó únicamente el dominio $B\left(A c e 2^{\mathrm{M}}-\Delta B\right)$. Cuando se analizó esta cepa, se observó que el porcentaje de separación era similar al observado en la cepa portadora de $A c e 2^{\mathrm{M}}-\mathrm{A}$ y al mutante carente de la forma de membrana Ace 2 . Por tanto, estos resultados sugieren que la región B de la proteína es necesaria para la función de la forma de membrana durante la filamentación.

\subsubsection{Ace $2^{\mathrm{M}}$ y Ace2 ${ }^{\mathrm{N}}$ interaccionan con el complejo Cbk1-Mob2.}

El hecho de que la región B fuera necesaria para la inhibir la separación celular en las hifas resultaba interesante, pues trabajos previos indicaban que la región B de la proteína de S. cerevisiae está implicada en la interacción de Ace2 con el complejo Cbk1-Mob2 (Brace et al., 2011). Teniendo en cuenta el papel de Cbk1-Mob2 en la regulación de la separación celular mediante la activación de Ace2 y considerando que esta región es una de las mejor conservadas entre las proteínas de $S$. cerevisiae y $C$. albicans, cabía la posibilidad de que también fuera la región necesaria para la interacción Ace2-Cbk1-Mob2 en C. albicans. Para comprobar si Cbk1-Mob2 interaccionan específicamente con la forma de membrana de Ace2, se realizaron ensayos de co-inmunoprecipitación. Para ello,

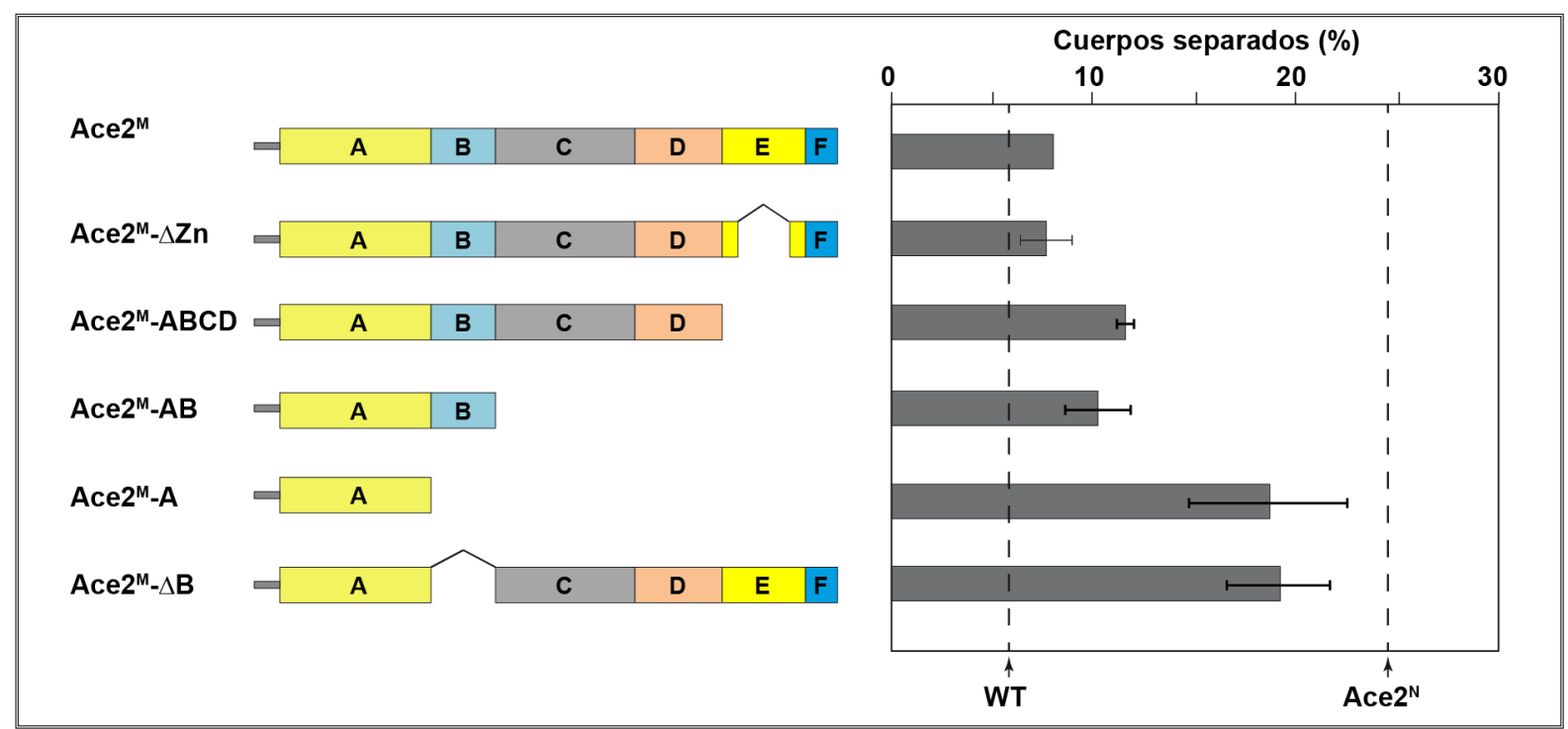

Figura 47. Estudio de las regiones de $A c e 2^{\mathrm{M}}$ necesarias para inhibir la separación celular en hifas. A la izquierda se muestra un esquema de las versiones truncadas de $A c e 2^{\mathrm{M}}$ generadas, que fueron insertadas en el locus RP10 bajo el control del promotor MET3. La gráfica de la derecha representa la cuantificación de cuerpos separados observados en los filamentos de las cepas ace $2 \triangle / A C E 2^{N} A C E 2^{M}:: R P 10$ (OL1170), ace $2 \triangle / A C E 2^{N} A C E 2^{M}-\triangle Z n:: R P 10$ (OL1191), ace $2 \triangle / A C E 2^{N} A C E 2^{M}-A B C D:: R P 10$ (OL1874), ace2 $/ A C E 2^{N}$ ACE2 ${ }^{M}-A B:: R P 10$ (OL1716), ace $2 \triangle / A C E 2^{N}$ $A C E 2^{M}-A:: R P 10(\mathrm{OL} 1714)$ y ace $2 \triangle / A C E 2^{N} A C E 2^{M}-\triangle B:: R P 10$ (OL1876). Con líneas de discontinuas se indican los porcentajes observados en la cepa silvestre (BWP17) y en el mutante ace $2 \triangle / A C E 2^{N}$ (OL1598). 


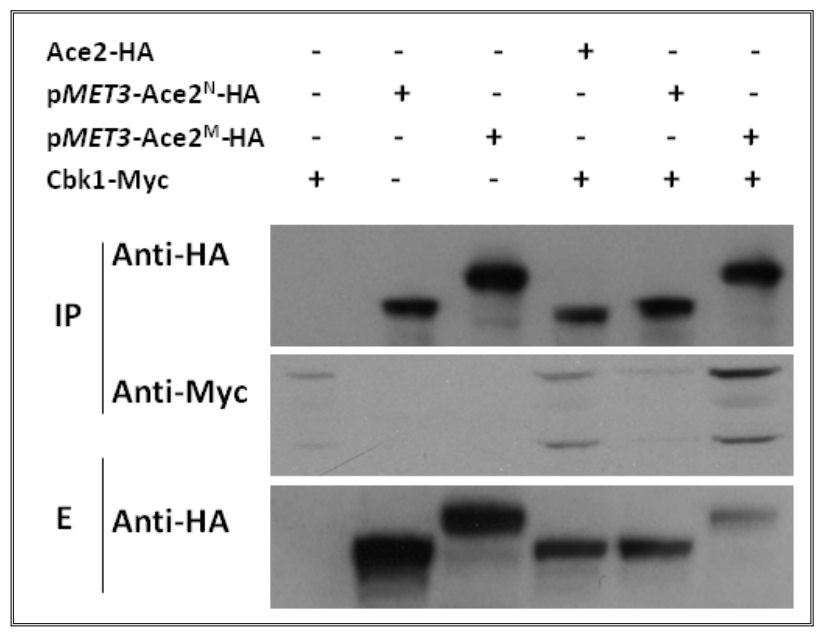

Figura 48. Ace $2^{\mathrm{M}}$ interacciona con el complejo Cbk1-Mob2. Extractos proteicos de células creciendo en forma de levaduras de las cepas CBK1-myc (OL1519), pMET3-ACE2N-HA (OL1111), PMET3-ACE2 ${ }^{M}-H A$ (OL1203), ACE2-HA CBK1-myc (OL1719), PMET3-ACE2 ${ }^{N}-H A$ CBK1-myc (OL1722) y pMET3-ACE2 ${ }^{M}-H A$ CBK1-myc (OL1994) fueron inmunoprecipitados usando anticuerpos anti-HA. Las muestras fueron separadas por SDSPAGE y analizadas con anticuerpos anti-HA y anti-myc.

se etiquetó a Cbk1 con el epítopo myc en una cepa ACE2-HA (marcada en su locus nativo y con su promotor) y en las cepas que contenían cada una de las proteínas de Ace2 marcadas con HA bajo el control del promotor MET3 insertadas en el locus RP10. Como control del experimento, se usó una cepa que contenía únicamente CBK1-myc. Las distintas cepas se pusieron a crecer en forma de levaduras, se prepararon extractos proteicos y se inmunoprecipitaron con anticuerpos anti-HA. Las proteínas inmunoprecipitadas fueron separadas en geles de acrilamida y analizadas mediante Western blot con anticuerpos anti-HA o anti-myc. Cuando se analizó la presencia de Cbk1 en los inmunoprecipitados, se comprobó que estaba presente en las cepas que sobreexpresaban Ace $2^{\mathrm{N}}$ y Ace ${ }^{\mathrm{M}}$, así como en la cepa que contenía Ace2 en su locus nativo (Fig. 48). A pesar de que en el control negativo también se observaron bandas correspondientes a Cbk1, la intensidad de la señal en las cepas que sobre-expresaban de las dos formas de Ace2 era superior, especialmente en la forma de membrana. Estas observaciones parecerían indicar que las dos formas de Ace2 son capaces de interaccionar con el complejo Cbk1-Mob2 en las condiciones ensayadas.

\subsubsection{Ace2 no es necesaria para la correcta localización de Gin4 en el septo.}

Teniendo en cuenta que la quinasa Gin4 regula la organización del anillo de septinas (Wightman et al., 2004) y que en la cepa mutante ace $2 \Delta / \Delta$ el anillo de septinas esta desorganizado, se planteo la posibilidad de que Ace2 pudiera regular la organización del anillo de septinas en hifas a través de esta quinasa. Con el fin de realizar una primera aproximación para comprobar si esta hipótesis era correcta, se decidió analizar si la localización de esta quinasa estaba alterada en la cepa ace $2 \Delta / \Delta$. Para ello, se fusionó la secuencia de la GFP al extremo 3' del

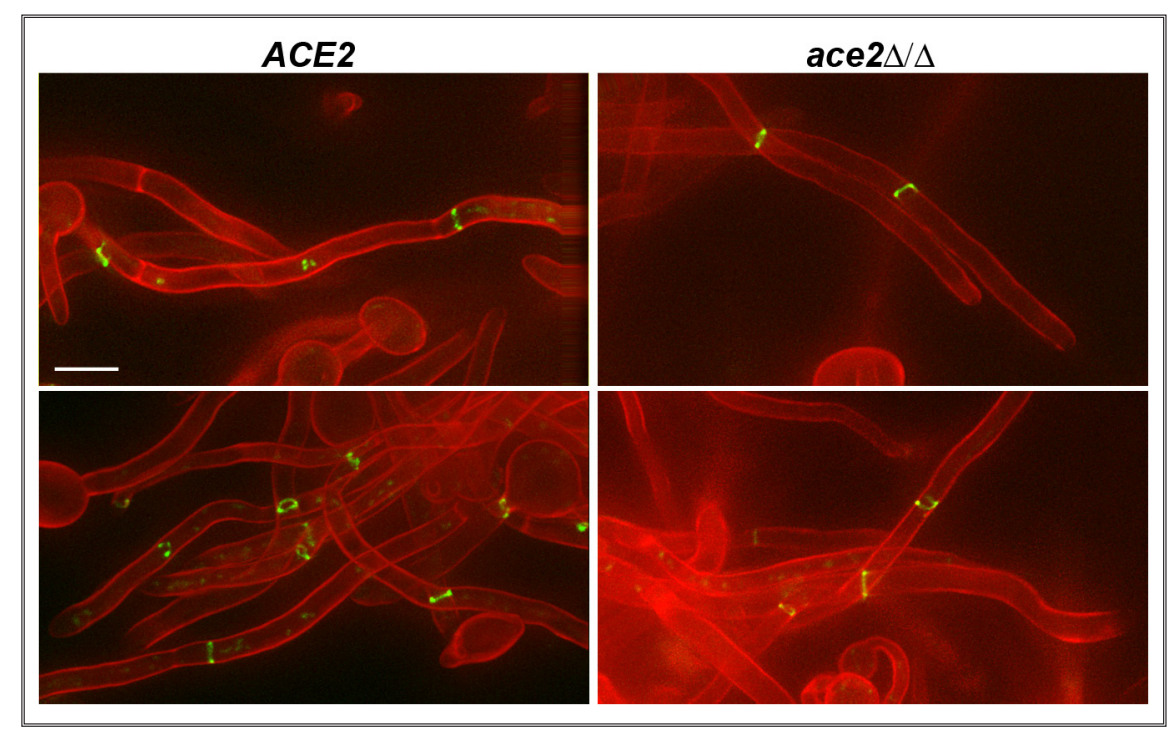

Figura 49. Localización de Gin4-GFP en condiciones de miceliación. Células en fase estacionaria de las cepas OL1484 (ace2 $/ \triangle$ GIN4-GFP) y ACE2 GIN4-GFP (OL1483) se incubaron en presencia de suero fetal bovino a $37^{\circ} \mathrm{C}$ durante 180 minutos. Las imágenes son la proyección máxima de 10 planos adquiridos cada 0,4 $\mu \mathrm{m}$ y muestran la fluorescencia de Gin4-GFP (verde) y la tinción de calcoflúor (rojo). Barra de escala, $5 \mu \mathrm{m}$. 
gen GIN4 tanto en un fondo silvestre como en el mutante carente del gen ACE2. Una vez comprobada la correcta integración de la GFP, se analizó la localización de la proteína Gin4-GFP en las hifas. Como puede observarse en la Figura 49, la regulación espacial de Gin4 no parece estar alterada en la cepa carente de Ace2, ya que esta quinasa se localiza en los anillos en ambos fondos genéticos. Por tanto, estos resultados preliminares parecen indicar que Ace2 no es necesario para la localización de esta quinasa en los septos, aunque será necesario comprobar si la actividad quinasa es la misma en ambas cepas. 

4. Discusión 



\subsection{EL LOCUS ACE2 DE C. albicans PRESENTA UNA COMPLEJA ESTRUCTURA}

Los resultados previos del grupo comentados anteriormente apuntaban a que el cambio en la dinámica del anillo de septinas era una señal necesaria en la ruta que regula la inhibición de la separación de las hifas. Cuando se analizó la dinámica del anillo de septinas en el mutante ace $2 \Delta / \Delta$ para confirmar que Ace2 se encontraba por debajo de las septinas en esta ruta, sorprendentemente se encontró que la dinámica era similar a la del mutante $\operatorname{sep} 7 \Delta / \Delta$, en lugar de ser como la de la cepa silvestre. Esta observación ponía de manifiesto la existencia de un bucle de retroalimentación en la regulación, de tal manera que las septinas son necesarias para inhibir la separación en hifas, pero al mismo tiempo Ace2 participa en la conversión del anillo de septinas al HSS. El hecho de que la actividad transcripcional de Ace2 no fuera necesaria para regular las septinas descartaba la explicación más sencilla, que Ace 2 controlara la expresión de algún gen (o genes) cuyo producto fuera el regulador directo del cambio en la dinámica de las septinas, e indicaba que dependía directamente de alguna de las regiones de la proteína Ace2 excepto de los dedos de Zinc. El análisis de la secuencia de aminoácidos de la proteína Ace2 depositada en las bases de datos CGD (http://www.candidagenome.org/) o CandidaDB (http://genolist. pasteur.fr/CandidaDB/) reveló una peculiaridad en el extremo N-terminal de esta proteína en comparación con los ortólogos presentes en otros hongos y levaduras, y es que en C. albicans la secuencia era 54 aminoácidos más larga que en el resto de las especies analizadas (Fig. 23). Dentro de esta región también estaba anotada en las bases de datos una posible región transmembrana (TM, residuos 15-40), y en una búsqueda informática de posibles sitios de fosforilación de la Ndr quinasa Cbk1 (H-X-R-R-X-[S/T]) (Mazanka et al., 2008) se encontró una posible diana entre los aminoácidos 44 y 49 (HSFRST). Estas dos características, especialmente la presencia de una región TM, diferenciaban a la proteína CaAce2 del resto de sus ortólogos, incluyendo S. cerevisiae, en los que no se ha detectado ninguna región con estas características. De hecho, la presencia de un dominio TM en un factor de transcripción plantea la cuestión de cómo podría entrar en el núcleo estando unido a alguna membrana celular. Una posibilidad sería que inicialmente Ace2 se sintetizara como una proteína de membrana y que bajo determinadas condiciones o en un momento concreto del ciclo celular sufriera un procesamiento proteolítico que liberara a la proteína de la membrana y permitiera su entrada al núcleo. De hecho, existen ejemplos en otros organismos, especialmente en plantas, de factores de transcripción unidos a membranas que en condiciones de estrés se procesan y activan la transcripción de grupos de genes específicos (revisado en Chen et al., 2008; Seo et al., 2008). Alternativamente, podría ocurrir que esta región no estuviera presente en la proteína, siendo únicamente un problema de anotación de las bases de datos. Esta posibilidad se basaba en el hecho de que existe una segunda metionina en la misma fase de lectura que se alinea perfectamente con el inicio de traducción del resto de los ortólogos, que podría ser el inicio de la proteína si el primer ATG no estuviera presente en el mRNA.

Es por ello que se diseñó un conjunto de experimentos encaminados a comprobar si el ATG1 estaba presente en el mRNA y tratar de determinar el punto de inicio de la transcripción del gen ACE2, mediante técnicas como RACE, RT-PCR y qRT-PCR. Los resultados mostraron que ACE2 se transcribe dando lugar a varios mensajeros distintos, cuyas abundancias relativas varían en función del patrón de crecimiento. Existen tres posibles puntos de inicio de la transcripción situados entre el ATG1 y el ATG2, en las posiciones -56, -84 y -112 (considerando como +1 la A del ATG2; Fig. 26), por lo que en estos tres mRNAs el primer AUG es el correspondiente al ATG2 y al traducirse darían lugar a la misma proteína, similar en tamaño a la del resto de los ortólogos (se ha denominado a esta forma $A c e 2^{N}$ por su localización y función). Adicionalmente, también se identificó otro posible punto de inicio de la transcripción en posición -411, lo que genera un mensajero mucho más largo que los anteriores y que contiene el ATG1 en su secuencia, por lo que su traducción podría dar lugar a otra forma proteica que contiene el 
dominio TM $\left(\right.$ Ace $\left.{ }^{\mathrm{M}}\right)$. La presencia de múltiples sitios de inicio de transcripción podría deberse al hecho de que ACE2 no se hayan detectado cajas TATA, que son las que regulan el anclaje de la RNA polimerasa II al promotor de los genes (Vannini y Cramer, 2012). Mediante determinaciones cuantitativas de la cantidad de los distintos mRNAs se comprobó que las abundancias relativas de las dos poblaciones varían en las distintas morfologías de C. albicans. Así, la cantidad del mRNA largo (el que comienza en posición -411) aumenta durante el proceso de filamentación, pasando de representar un 6\% del total de los transcritos de ACE2 en levaduras al $24 \%$ en hifas. Esto podría indicar que la proteína que se traduce a partir de dicho mensajero es más importante durante este estado morfológico.

Cuando se analiza la secuencia de ACE2 depositada en la base de datos CGD, la situación se complica aún más, pues el locus ACE2 es heterocigótico, ya que el promotor de uno de los dos alelos contiene un transposón de la familia kahu (el LTR asociado con el transposón Tca15) (Goodwin y Poulter, 2000). Cuando se comparó la secuencia de DNA de los distintos clones obtenidos por RACE con las secuencias genómicas, se comprobó que los tres puntos de inicio de la transcripción que corresponden al mRNA corto están presentes en los dos alelos (Fig. 50A). Por el contrario, el extremo del mRNA largo corresponde específicamente al alelo que contiene el transposón kahu. Estos resultados parecen indicar, por tanto, que la transcripción de la forma larga es específica de uno de los alelos, y apuntan a la posibilidad de que la inserción del transposón haya creado un promotor alternativo que altera la expresión génica, produciendo una nueva forma de mRNA que no existía originalmente en este locus. Sin embargo, experimentos preliminares de qRT-PCR utilizando cepas heterocigóticas en las que se ha delecionado cada uno de los dos alelos independientemente indican que ambas formas de mRNA se detectan en las dos cepas (datos no mostrados). Por tanto, cabe la posibilidad de que el punto de inicio de la transcripción identificado en -411 no sea el único extremo del mRNA largo, y que existan otras formas adicionales (que contengan el AUG1 y se expresen desde ambos alelos) que no hayan sido clonadas en los ensayos de RACE realizados. Será necesario confirmar de forma inequívoca si el mRNA de mayor tamaño se produce a partir de los dos alelos o únicamente a partir del alelo kahu-ACE2.

Otra observación interesante cuando se analiza la región 5'-UTR del mRNA largo clonado es que existen 5 AUGs

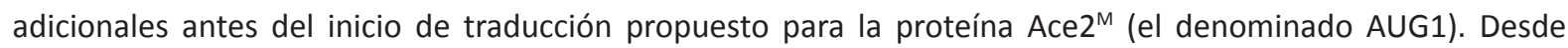
que en 1989 Marilyn Kozak propuso el modelo de "scanning" para el inicio de la traducción, es ampliamente aceptado que la presencia de AUGs adicionales en la región 5'-UTR del mRNA reduce o impide la traducción de otros AUGs situados después de él. Esto se debe a que, según este modelo, la subunidad 40S del ribosoma se une al extremo 5' del mRNA y avanza en dirección 3' hasta encontrar el primer AUG, momento en el que se ensambla sobre ella la subunidad 60S y comienza la traducción (Kozak, 1989). Es por ello que, por norma general, las fases de lectura que se encuentran antes del inicio de traducción de una proteína (denominadas uORFs, por "upstream Open Reading Frames") impiden o reducen considerablemente su traducción. Sin embargo, existen mecanismos alternativos menos comunes que permiten la traducción de mensajeros que contienen uORFS (revisado en Hellen y Sarnow, 2001; Kelen et al., 2009; Kozak, 2002; Kozak, 2005). Uno de ellos es el denominado reiniciación, cuyo ejemplo mejor conocido es el del factor de transcripción GCN4 de S. cerevisiae. Gcn4 controla la expresión de un numeroso grupo de genes implicados en la biosíntesis de aminoácidos, y su traducción en condiciones de crecimiento en las que hay abundancia de aminoácidos en el medio de cultivo está reprimida por la presencia de 4 uORFs presentes en el mRNA (revisado en Hinnebusch, 1997; Hinnebusch, 2011). En estas condiciones, las uORFS actúan como una barrera que impide a las subunidades 405 alcanzar el codón de inicio de GCN4, ya que los ribosomas traducen el uORF1 y posteriormente reinician en el uORF3 o uORF4. Sin embargo, en condiciones en las que hay limitación de aminoácidos, la quinasa Gcn2 fosforila la subunidad $\alpha$ del factor de 
inicio de la traducción 2 (elF $2 \alpha$ ) en la Ser51 y esto produce una reducción en la cantidad del complejo ternario

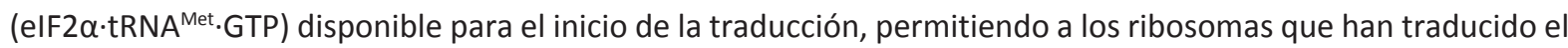
uORF1 reiniciar la traducción en el AUG de GCN4. Por tanto, en condiciones en la que la tasa global de traducción de la célula se reduce, se produce un aumento de la traducción de GCN4, lo que activa la expresión implicados en la biosíntesis de aminoácidos y su síntesis intracelular.

En el caso de ACE2 de C. albicans, podría también ocurrir que la presencia de los 5 uORFS fuera necesaria para regular la traducción de la forma $A c e 2^{\mathrm{M}}$ en determinadas condiciones. Sin embargo, el mecanismo de regulación debe ser diferente del descrito para GCN4, ya que no es lógico pensar que la abundancia de aminoácidos regule la traducción de $A c e 2^{\mathrm{M}}$, puesto que Ace 2 no controa la expresión de genes biosintéticos de aminoácidos. Además, la estructura de los uORFs presentes en GCN4 y en $A C E 2^{M}$ es completamente diferente (Fig. 50B). Así, mientras que en GCN4 las uORFS son pequeñas y codifican cada una de ellas para 2-3 aminoácidos únicamente (y esto es esencial para permitir la reiniciación de la traducción), las 5 uORFS de ACE2 codifican para péptidos mayores, de entre 2 y 40 aminoácidos (uORF3 y uORF1, respectivamente). Por ello, es improbable que el mecanismo de reiniciación regule la traducción de $A C E 2^{M}$.

Un segundo mecanismo para traducir mRNAs que contienen uORFs es el denominado "leaky scanning". En aquellos casos en los que el primer AUG se encuentra en un contexto que no favorece la iniciación de la traducción y el segundo (o a veces el tercero) AUG presenta un contexto óptimo (GCCRCCaugG en eucariotas, Kozak, 2005), algunas de las subunidades $40 S$ pueden omitir el primer AUG e iniciar en el segundo o tercero. Si los dos AUGs están en la misma fase de lectura, se producen dos proteínas que difieren en tamaño, una de las cuales puede presentar una localización diferente de la otra, como ocurre en el caso de enzima degradante de insulina (IDE), del que se generan dos formas por "leaky scanning", una de las cuales se localiza en la mitocondria (Leissring et al., 2004). Este tampoco parece ser el caso de $A C E 2^{M}$, ya que el AUG de inicio es el sexto de los presentes en el 5'-UTR del mRNA y todos ellos se encuentran en un contexto pobre de inicio de la traducción.

El tercer mecanismo es conocido como "ribosome shunting" y ocurre en aquellos casos en los que existen estructuras secundarias fuertes en el mRNA que detienen el escaneo de los ribosomas. Estas estructuras secundarias permiten que el ribosoma "salte" de un extremo a otro de la estructura secundaria y omita los posibles AUGs presentes en esa región. Este mecanismo es típico

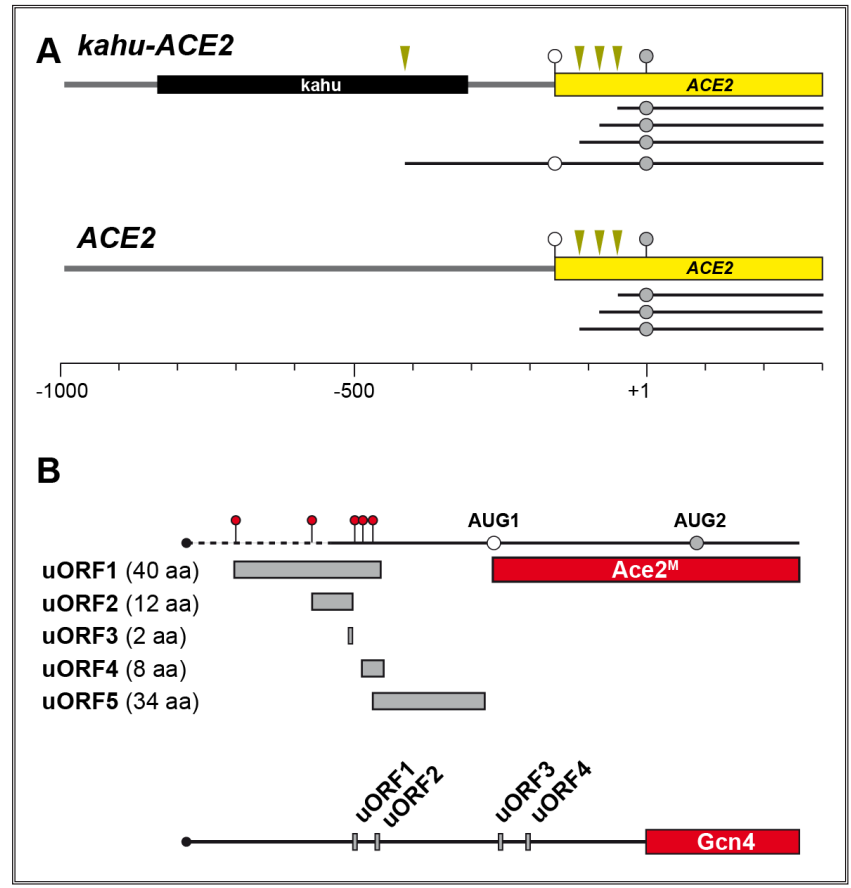

Figura 50. A Esquema representativo de los alelos kahu-ACE2 y ACE2 del locus ACE2 de $C$. albicans. Se representa a escala la posición del transposón kahu (negro), el ATG1 y ATG2 de ACE2 (circulo blanco y gris, respectivamente) y la posición de los sitios de inicio de la transcripción identificados (triángulos verdes). Debajo de cada alelo se indican los mRNAs que se transcribirían a partir de cada uno de ellos. Para la numeración, se ha considerado como +1 la A del ATG2. Por simplicidad, de la ORF de ACE2 se han representado únicamente los primeros 300 nucleótidos. B. Esquema representativo de la estructura del mRNA largo de ACE2, en el que se indica la posición del AUG1 y AUG2, así como los 5 AUGs adicionales presentes en la región $5^{\prime}$-UTR (círculos rojos). Debajo se muestran las fases de lectura que dan lugar cada uno de estos AUGs, junto con su número de aminoácidos. De nuevo, se ha representado únicamente la extremo $5^{\prime}$ del mRNA. Para comparación, se muestra debajo la estructura de la región 5'UTR del mensajero de GCN4 de S. cerevisiae. 
de RNAs virales, como el virus del mosaico de la colifor (CaMV) (Fütterer et al., 1993). Dado que el extremo 5' del mRNA largo de ACE2 corresponde a la secuencia del LTR de transposón kahu, este podría ser un mecanismo que ocurriera en el caso de $A C E 2^{M}$, aunque no se ha analizado la estructura secundaria del mRNA.

Finalmente, existe otro mecanismo para traducir mRNAs que poseen uORFs, y es la presencia de sitios de entrada interna de ribosomas ("Internal Ribosome Entry Sites" o IRES) (revisado en Hellen y Sarnow, 2001). Estos sitios se localizan en la región 5'-UTR del mRNA y permiten la traducción de mensajeros de forma independiente del "cap". Los RNAs que contienen IRES no están controlados por los mismos mecanismos que regulan el reclutamiento de la mayoría de los mRNAs al aparato traduccional. Este es un mecanismo relativamente corriente en RNAs procariotas y virales, aunque también existe en células eucariotas. Es interesante que muchos de los ejemplos conocidos de mRNAs con IRES en eucariotas son genes que codifican para factores de crecimiento (como el factor de crecimiento 2 de fibroblastos FGF2, el factor de plaquetas PDGF/c-sis o el factor de crecimiento endotelial vascular VEGF), factores de transcripción (Antennapedia, Ultrabithorax o la proteína con homeodominios Gtx), oncogenes (c-myc o Pim-1) o activadores de apoptosis (el factor activante de la proteasa apoptótica Apaf-1). En muchos de estos casos, el aumento de la traducción de estos RNAs se correlaciona con condiciones en las que la traducción general dependiente del "cap" se inhibe. Este mecanismo podría operar en la traducción del mensajero mayor de ACE2, aunque el hecho de que no exista un consenso para identificar los IRES y de que las características estructurales de estos elementos en células eucariotas sean ampliamente desconocidas no permite afirmarlo.

\subsection{C. albicans POSEE DOS FORMAS DE LA PROTEÍNA Ace2 CON PROPIEDADES DISTINTAS.}

El hecho de que en C. albicans el gen ACE2 se transcriba en dos poblaciones de mRNA y una de ellas contenga el inicio de traducción que da lugar a una proteína con una posible región transmembrana plantea seriamente la posibilidad de que en la célula existan dos isoformas diferentes de Ace2 con diferente localización. De hecho, la producción de dos proteínas diferentes a partir de un único gen por el uso de puntos alternativos de inicio de la transcripción es común, como ocurre en el gen SUC2 de S. cerevisiae. A partir de SUC2 se producen dos formas de invertasa diferentes que difieren por la presencia de una secuencia señal de secreción en una de ellas. La forma intracelular se produce de forma constitutiva, mientras que la extracelular que contiene la secuencia señal está regulada por fuente de glucosa (Carlson y Botstein, 1982; Perlman et al., 1984). Por ello, el siguiente objetivo de trabajo que se planteó fue el comprobar experimentalmente si las dos formas estaban presentes en la célula y, en caso afirmativo, realizar una caracterización bioquímica de ellas. A pesar de las múltiples aproximaciones experimentales utilizadas para tratar de detectar la presencia de $A c e 2^{\mathrm{M}}$ en cepas que expresan esta proteína con el promotor nativo de ACE2, ninguna de ellas ha resultado positiva ni en levaduras ni en hifas.

Existen varias posibilidades que pueden explicar este hecho. En primer lugar, Ace ${ }^{\mathrm{M}}$ podría ser una proteína muy inestable y de vida media corta. Sin embargo, a pesar de que no se ha analizado directamente la estabilidad de la proteína, los experimentos realizados utilizando el promotor $P M E T 3$ indican que la cantidad de Ace ${ }^{\mathrm{M}}$ observada tanto en hifas como en levaduras es similar (o incluso ligeramente superior) a la observada en las cepas que sobreexpresan $A c e 2^{\mathrm{N}}$. Otra posibilidad es que al tener un posible dominio transmembrana, las condiciones utilizadas para su solubilización no hayan sido las correctas a pesar de haber probado varias alternativas, algunas de las cuales son capaces de solubilizar proteínas con más de un dominio TM como Pma1. Sin embargo, el hecho de que en la cepa $P M E T 3-A C E 2^{\mathrm{M}}$ se detecte en condiciones similares a las usadas para $A c e 2^{\mathrm{N}}$ descarta esta posibilidad. Otra alternativa es que $A c e 2^{\mathrm{M}}$ sea una proteína que se expresa (o se traduce) en un momento muy 
concreto del ciclo celular, lo que unido a que el RNA mensajero largo representa un porcentaje bajo del RNA total de $A C E 2$, resultaría en que no sea fácilmente detectable en cultivos asincrónicos como los que se usaron para la caracterización bioquímica de la proteína.

Sin embargo, una hipótesis más plausible en vista de la existencia de 5 uORFs en la región $5^{\prime}$-UTR del mensajero largo y de lo discutido en el apartado anterior, es que la traducción de este mensajero sea ineficiente u ocurra bajo condiciones muy concretas que no ha sido posible determinar. De hecho, cuando se sustituye el promotor nativo por el promotor PMET3, es posible detectar la proteína Ace $2^{\mathrm{M}}$ sin problemas. En este caso, la sustitución de un promotor por otro no solo aumenta el nivel de expresión del gen, sino que cambia completamente la secuencia y estructura de la región 5'-UTR del mensajero, eliminando al mismo tiempo los 5 uORFs, por lo que además de aumentar la cantidad del mRNA que contiene el AUG1, también aumentaría su traducción al eliminar la barrera traduccional que suponen los UORFS. Es evidente que será necesario realizar una confirmación experimental de esta hipótesis y comprobar si los uORFS desempeñan algún papel en la regulación de la traducción del mRNA largo. Sin duda alguna, un experimento que podría aportar importante información sobre este aspecto es la generación de una cepa que contenga mutaciones puntuales en los AUGs de los 5 uORFs, eliminando de esta manera la posible barrera que suponen para los ribosomas, para comprobar si la traducción de Ace $2^{\mathrm{M}}$ aumenta en esta cepa.

Debido a la imposibilidad para detectar la proteína $A c e 2^{\mathrm{M}}$ a partir de su propio promotor, se utilizaron las cepas que expresan ambas formas a partir del promotor PMET3 para realizar una caracterización bioquímica de las proteínas, asumiendo que si la traducción comienza en el mismo AUG, las propiedades de las proteínas sintetizadas deben ser idénticas. Utilizando este sistema de sobreexpresión, se pudo comprobar que las formas $A c e 2^{\mathrm{M}}$ y Ace $2^{\mathrm{N}}$ presentan características diferentes en cuanto a movilidad electroforética, sedimentación en gradientes de sacarosa o nivel de fosforilación. Estos experimentos, junto con las observaciones microscópicas de la localización de las proteínas con su promotor nativo o en sobreexpresión, indican claramente que son dos formas con propiedades completamente distintas. Así, la forma corta que comienza en la Met2 parece corresponder a la proteína nuclear que en los ortólogos de otros organismos funciona como factor de transcripción, ya que se localiza en el núcleo de la célula y fracciona con un marcador nuclear en gradientes de sacarosa, por lo que se denominó $A c e 2^{\mathrm{N}}$. Por el contrario, la forma que se traduce a partir del AUG1 presenta una localización y sedimentación completamente diferentes, lo que indica que los 54 aminoácidos adicionales presentes en esta proteína modifican sus propiedades. El hipotético dominio transmembrana anotado en las bases de datos parece ser funcional en $A c e 2^{\mathrm{M}}$, ya que esta proteína localiza “in vivo" como un patrón citoplásmico punteado que podría corresponder a algún tipo de vesículas intracelulares y en gradientes de sedimentación parece estar asociado mayoritariamente a las fracciones donde localizan otros compartimentos de membrana, como marcadores del aparato de Golgi. El hecho de que cuando se clonan estos 54 aminoácidos delante de un gen heterólogo como GFP altere el patrón de localización de la proteína de fusión resultante y ésta se localice en retículo endoplásmico y vesículas confirma claramente que el posible dominio TM de Ace2 es funcional y capaz de dirigir a una proteína heteróloga a la ruta secretora.

Los resultados de las observaciones de la localización de las distintas proteínas mediante microscopía de fluorescencia confirman los datos bioquímicos y demuestran que las dos formas de Ace 2 presentan localizaciones subcelulares diferentes, una de ellas asociada a membrana. Durante los últimos años se ha puesto de manifiesto que la existencia de factores de transcripción unidos a membranas ("Membrane-Tethered Transcription Factors" o MTTFs) es un mecanismo frecuente en diversas rutas de señalización que controlan diversas respuestas 
celulares (revisado en Lal y Caplan, 2011; Slabaugh y Brandizzi, 2011; Urban, 2009). En estos casos, los factores de transcripción se sintetizan como precursores con uno o varios dominios transmembrana, por lo que se mantienen en un estado inactivo debido a su asociación a membranas intracelulares. Bajo ciertas condiciones, se produce un procesamiento proteolítico controlado que libera la forma activa que entra en el núcleo y activa la transcripción de grupos de genes concretos. Se ha propuesto que el procesamiento controlado de los MTTFs y su liberación de la membrana es una estrategia adaptativa que permite una respuesta transcripcional rápida ante cambios ambientales. Los MTTFs se activan por dos mecanismos diferentes. El primero se regula por ubiquitinación y degradación por el proteasoma (conocido como RUP, por "Regulated Ubiquitin/proteosomedependent Processing"). Por ejemplo, el factor de transcripción Spt23/Mga2 de S. cerevisiae se procesa por esta ruta. Spt23/Mga2 regula la expresión del gen OLE1, que codifica la enzima que participa en la biosíntesis de ácidos grasos insaturados. Se sintetiza como un precursor asociado a la membrana del retículo endoplásmico, donde permanece hasta que se necesitan ácidos grasos insaturados, momento en el que se procesa y entra en el núcleo (Hoppe et al., 2000; Murakami et al., 2006). El segundo mecanismo de liberación de la forma activa es proteólisis intramembranal regulada ("Regulated Intramembrane Proteolysis" o RIP), mediada por proteasas integrales de membrana. Este es el caso, por ejemplo, del factor OASIS de humanos, que forma parte de la respuesta a proteínas mal plegadas en el RE (“Unfolded Protein Response” o UPR). OASIS está asociado a la membrana del RE y se activa cuando se acumulan proteínas mal plegadas en el RE por un procesamiento proteolítico que ocurre dentro del dominio transmembrana por dos proteasas integrales de membrana (Hoppe et al., 2000; Murakami et al., 2006). Los MTTFs también son importantes en plantas, donde median distintas rutas de respuesta a estrés, por lo que parecen ser esenciales para la adaptación a estrés (Chen et al., 2008; Seo et al., 2008). En todo caso, todos los ejemplos conocidos de MTTFs constituyen un mecanismo para mantener secuestrada la actividad transcripcional hasta que es necesaria para desencadenar una respuesta rápida a condiciones cambiantes. Sin embargo, este no parece ser el caso de Ace2 en C. albicans, ya que no se han encontrado evidencias que induzcan a pensar que $A c e 2^{\mathrm{M}}$ se procese y actúe como factor de transcripción. Así, el fenotipo de las cepas que contienen únicamente $A c e 2^{\mathrm{M}}$ es idéntico al del mutante $a c e 2 \Delta / \Delta$, formando grupos de células incapaces de separarse (indicando una ausencia de actividad transcripcional), y no hemos encontrado condiciones que induzcan la separación (distintos medios o temperaturas) en esta cepa. Adicionalmente, en células que contienen PMET3-Ace2 ${ }^{\mathrm{M}}$ no se ha detectado ningún fragmento de menor tamaño ni en células de levaduras ni en hifas (incluso tras 6 horas de inducción de la filamentación, datos no mostrados) que pudiesen sugerir la existencia de un procesamiento proteolítico de la proteína $A c e 2^{\mathrm{M}}$. Estás dos observaciones conducen a pensar que la función de $A c e 2^{\mathrm{M}}$ no es mantener a la forma con actividad transcripcional secuestrada en la membrana hasta que se necesite, sino que parece ser diferente a las descritas para otros MTTFs.

\subsection{FUNCIONES DE LAS DOS FORMAS DE ACe2 EN LOS DISTINTOS ESTADOS MORFOGÉNETICOS.}

Como se ha comentado anteriormente, durante la filamentación de $C$. albicans parece existir una correlación directa entre el cambio en la dinámica del anillo de septinas y la inhibición de la separación celular (GonzálezNovo et al., 2008). El objetivo inicial de la presente Memoria era estudiar la regulación de la separación celular en las hifas de $C$. albicans, especialmente la participación del factor de transcripción Ace2 en este proceso. Para confirmar que Ace2 se encontraba regulado por la dinámica del anillo de septinas, se analizó la dinámica del anillo en el mutante $a c e 2 \Delta / \Delta$. Sorprendentemente, los resultados mostraron que las septinas y el factor de transcripción Ace 2 forman una red que se regula mutuamente, ya que mientras que las septinas son necesarias para inhibir la separación celular en hifas, Ace2 controla la transición del anillo de septinas a la forma específica de hifas. También se ha demostrado que la regulación de las septinas no depende de la actividad transcripcional de 
la proteína Ace2, ya que en un mutante carente de los dedos de zinc (Ace2- $\Delta \mathrm{Zn}$ ) la dinámica del anillo era similar a la de hifas silvestres. La identificación de dos formas diferentes de Ace2, una de ellas asociada a membranas, ofrecía una posible explicación a este mecanismo, ya que al existir dos formas diferentes, las funciones de cada una de ellas podrían ser distintas. El análisis detallado de los fenotipos de cepas que contenían solamente una de las dos formas de Ace2 (generadas mediante mutagénesis puntual de cada uno de los ATGs) ha permitido confirmar que cada proteína desempeña una función diferente, con mayor o menor relevancia, dependiendo de la forma de crecimiento del hongo. A continuación se discutirá en detalle cada una de estas funciones.

\subsubsection{Función de la forma nuclear de Ace2.}

En S. cerevisiae, Ace2 regula la expresión de la quitinasa Cts1 y otras glucanasas y proteínas implicadas en la separación celular, las cuales se secretan a la zona del septo desde la célula hija (Baladrón et al., 2002; ColmanLerner et al., 2001). Los mutantes carentes de Ace2 en S. cerevisiae forman grupos de células incapaces de disolver el septo de separación entre las células madre e hija. En C. albicans, el fenotipo del mutante $a c e 2 \Delta / \Delta$ es similar al de S. cerevisiae (Kelly et al., 2004). El análisis de fenotipo de la cepa ace $2 \Delta / A C E 2^{M}$ (carente por tanto de la forma nuclear) mostró que el fenotipo era idéntico al del mutante ace $2 \Delta / \Delta$ durante el crecimiento en forma de levaduras. Por el contrario, la cepa ace $2 \triangle / A C E 2^{N}$ no presentó ningún fenotipo aparente durante esta fase de crecimiento. Por tanto, estos resultados indican claramente que Ace ${ }^{\mathrm{N}}$ es la forma que funciona como factor de transcripción en $C$. albicans, mientras que la forma de membrana no parece desempeñar ninguna función esencial en levaduras.

Como se ha comentado en la Introducción, en S. cerevisiae la acumulación nuclear de Ace2 está estrictamente regulada temporal y espacialmente, de tal manera que se acumula únicamente en el núcleo de la célula hija durante la transición M/G1 (Mazanka et al., 2008; Weiss et al., 2002). Esta regulación ocurre por diferentes quinasas que fosforilan distintos sitios en la proteína. La fosforilación por Cdc28 ocurre en varios sitios, dos de los cuales se encuentran en el extremo C-terminal detrás de los dedos de Zn, donde también se localiza la señal de localización nuclear (NLS), y se ha descrito que mientras Ace2 está fosforilada en estos sitios, su entrada en el núcleo está bloqueada. Además, también existen dos sitios de fosforilación por Cbk1-Mob2 cerca del extremo N-terminal que flanquean la señal de exportación nuclear (NES), de tal manera que la fosforilación de estos sitios bloquea la exportación de la proteína y permite su acumulación en el núcleo de la célula hija. En C. albicans, la forma nuclear también presenta un alto grado de fosforilación, similar a lo descrito para Ace2 en otros organismos como S. cerevisiae o S. pombe (Alonso-Nuñez et al., 2005; Petit et al., 2005; Weiss, et al., 2002), por lo que es posible que su localización o actividad estén regulados por mecanismos similares. En C. albicans, al menos parte de este mecanismo parece estar conservado, por lo que la forma $A c e 2^{\mathrm{N}}$ también podría tener regulada su acumulación nuclear en un momento concreto del ciclo. Los dos sitios de fosforilación de Cbk1-Mob2 y el sitio NES son una de las regiones más conservadas entre las proteínas de $S$. cerevisiae y $C$. albicans (Fig. 46) además de los dedos de Zinc, por lo que cabe suponer que, aunque no se ha comprobado experimentalmente, esta parte del mecanismo esté conservada entre ambas levaduras. De hecho, se ha comprobado que tanto Ace $2^{\mathrm{N}}$ como Ace $2^{\mathrm{M}}$ co-inmunoprecipitan con el complejo Cbk1-Mob2. Sin embargo, el tercer sitio de fosforilación por Cbk1-Mob2 que existe en Ace2 de S. cerevisiae (S436) y cuya fosforilación es importante para aumentar su actividad transcripcional (Mazanka et al., 2008) no está conservado en C. albicans. La segunda parte del mecanismo de regulación de entrada al núcleo parece estar menos conservada. Así, a pesar de que existen 7 sitios consenso completos de fosforilación por Cdc28 en Ace2 de C. albicans, los dos del extremo carboxilo no están presentes, y esta región está menos conservada, por lo que podría ocurrir que la actividad CDK no sea esencial para regular la entrada en el núcleo sino que desempeñe una función diferente en $C$. albicans. Será 
necesario comprobar si en C. albicans tanto Cdc28 como la fosfatasa Cdc14 desempeñan algún papel en la regulación de la entrada de Ace2 en el núcleo.

Por tanto, a pesar de los parecidos entre Ace2 en S. cerevisiae y C. albicans, y de que en ambas levaduras se acumula de forma asimétrica en el núcleo de la célula hija, es posible que los mecanismos moleculares que regulan su acumulación nuclear no sean exactamente idénticos y que existan algunas peculiaridades en cada organismo. De hecho, en C. albicans Ace2 también es necesario para inducir la expresión de genes que codifican para enzimas glicolíticas y reprimir los genes de respiración (Mulhern et al., 2006). Ya que la regulación de la glicolisis y respiración deben ser independientes del ciclo celular, una posibilidad muy interesante es que en $C$. albicans no sea la entrada nuclear la que esté estrechamente regulada, sino la unión a determinados grupos de promotores. Es decir, si la entrada de Ace2 al núcleo fuera independiente de la actividad CDK, o pudiera ocurrir en cualquier fase del ciclo celular si las condiciones de oxigenación del medio de cultivo cambian drásticamente, podría unirse al promotor de los genes implicados en glicolisis/respiración y activar su transcripción. Una vez en el núcleo, durante la transición M/G1 sólo sería necesario modificar su afinidad por los promotores de los genes implicados en separación celular para activar la expresión de este otro grupo de genes, y es muy tentador especular que esta podría ser la función de Cbk1-Mob2.

Durante la inducción de la filamentación, Ace $2^{\mathrm{N}}$ no parece desempeñar ningún papel relevante en la morfogénesis, ya que los mutantes (ace $2 \triangle / A C E 2^{M}$ ) que carecen de esta isoforma forman hifas similares a las de la cepa silvestre en todos los parámetros analizados. Ace $2^{\mathrm{N}}$ se localiza en el núcleo de los compartimentos hifales, aunque la expresión de los genes necesarios para la separación celular está inhibida. Esta inhibición depende tanto del cambio de la dinámica del anillo de septinas a la forma específica de hifas como del represor Efg1, que se une a los promotores de los genes regulados por Ace2 (González-Novo et al., 2008; Wang et al., 2009).

\subsubsection{Función de la forma de membrana de Ace2.}

Una de las características morfogenéticas más importantes de $C$. albicans es su habilidad para realizar transiciones morfológicas entre levaduras e hifas en respuesta a ciertos estímulos ambientales, fenómeno que reviste una importancia crítica en la patogénesis del hongo (Odds, 1988). El crecimiento en forma de hifas presenta varias características que lo diferencian del crecimiento levaduriforme. En primer lugar, existe un crecimiento apical continuo que se ve reflejado en el patrón de polarización de la actina, que se concentra en forma de parches en la punta de la hifa y cables longitudinales que se orientan hacia la punta (Sudbery et al., 2004). Segundo, durante el crecimiento hifal la separación de los compartimentos celulares se encuentra inhibida, permitiendo la formación de los filamentos septados. Por último, otra peculiaridad de las hifas de C. albicans es que los anillos de septinas no se desensamblan al terminar la citoquinesis, al contrario de lo que ocurre en levaduras (Warenda y Konopka, 2002). El análisis de los fenotipos de las cepas que carecían de la forma de membrana permitió determinar que esta proteína también tiene un papel diferente dependiendo de la morfología y que algunas de estas características de las hifas dependen de $A c e 2^{\mathrm{M}}$. Así, las levaduras de estos mutantes (ace $2 \Delta /$ $A C E 2^{N}$ ) no presentan diferencias significativas en su morfología o tasa de crecimiento en distintos medios o a diferentes temperaturas con respecto a la cepa silvestre. Adicionalmente, la sobreexpresión de Ace ${ }^{\mathrm{M}}$ usando el promotor PMET3 no produce ningún defecto morfológico observable. Estos resultados indican que la proteína de membrana no parece desempeñar ninguna función relevante durante el crecimiento levaduriforme, y esto concuerda bien con el hecho de que la cantidad de mensajero largo presente en levaduras sea relativamente baja (alrededor del $8 \%$ del total de mRNA). Por el contrario, la cepa que carece de la forma de membrana presentó una serie de defectos morfológicos durante la inducción de la filamentación, entre los que se incluyen un aumento en la distancia a la que se posiciona el primer septo dentro de la hifa, una incapacidad para convertir 
el anillo de septinas a la forma específica de hifas y, consecuentemente, una activación de la separación de los compartimentos hifales.

Los resultados obtenidos indican que la proteína $A c e 2^{\mathrm{M}}$ parece desempeñar una función importante en la morfogénesis de las hifas que es independiente de su actividad transcripcional, regulando la dinámica del anillo de septinas que es necesaria para inhibir la disolución del septo. Este mecanismo que ha generado dos formas de un factor de transcripción parece ser exclusivo de C. albicans, pues la región adicional presente en el extremo N-terminal no está conservada en otros hongos y levaduras (ni en otras especies del genero Candida), lo que sugiere que ha aparecido recientemente en la evolución, quizás como adaptación de C. albicans al crecimiento en nichos específicos. A pesar de ello, Ace2 parece estar relacionado con las septinas en otros hongos y levaduras, aunque el mecanismo sea diferente. Así, en S. pombe se ha descrito que Ace2 regula la estabilidad del anillo de septinas durante la citoquinesis, aunque en la levadura de fisión es un mecanismo diferente que implica la actividad transcripcional de Ace2. En S. pombe, Ace2 controla la expresión de mid $^{+}$y activa su transcripción en la transición M/G1, junto con el grupo de genes necesarios para disolver el septo (Alonso-Nuñez et al., 2005; Petit et al., 2005). Mid2 es una anillina necesaria para la estabilidad del anillo de septinas ortóloga de Bud4 de S. cerevisiae o Int1 de C. albicans (Berlin et al., 2003; Tasto et al., 2003). Adicionalmente, en S. cerevisiae se ha descrito que la deleción de ACE2 presenta un fenotipo sintético letal cuando se combina con la deleción de algunos genes de las septinas o sus reguladores (Costanzo et al., 2010). Así, de las 77 interacciones genéticas negativas identificadas en el análisis a escala genómica para el gen ACE2, dos de ellas corresponden a genes que codifican septinas (CDC10 y CDC11) y otras cuatro a algunos de sus reguladores, como las quinasas CLA4, ELM1 y GIN4 o RGA1 (el GAP de Cdc42). Estos resultados sugieren que en S. cerevisiae Ace2 podría tener algún papel en la regulación del anillo de septinas, funcionando en paralelo o independiente de Cla4, Elm1, Gin4 y Rga1, ya que la eliminación de ambas rutas resulta en letalidad sintética. Ninguno de estos genes está regulado transcripcionalmente por Ace2, por lo que podría ser que Ace2 en S. cerevisiae también tuviera una función independiente de su actividad transcripcional. Será interesante comprobar si en C. albicans la deleción de ACE2 también resulta en letalidad sintética cuando se combina con la deleción de los ortólogos de estos genes y si este efecto es especifico de las proteínas $A c e 2^{\mathrm{N}}$ o $A c e 2^{\mathrm{M}}$.

Todos los resultados obtenidos durante el desarrollo del presente trabajo llevan a proponer un modelo de regulación de la dinámica del anillo de septinas y separación celular durante el crecimiento filamentoso de $C$. albicans por parte de Ace2 que se esquematiza en la Figura 51. En este organismo, la transcripción del gen ACE2 da lugar a dos mensajeros de distinto tamaño, cuya traducción genera dos formas distintas de Ace2. Una de ellas se asocia a membranas a través de una región transmembrana presente en el extremo amino y se localiza en algún tipo de vesículas o compartimentos de membrana, mientras que la otra forma carece de la región TM y se acumula en el núcleo, funcionando como factor de transcripción. Durante el crecimiento filamentoso, Ace ${ }^{\mathrm{M}}$ parece ser un nuevo factor que regula la conversión del anillo de septinas al estado específico de hifas, junto con Sep7 y Hgc1 descritos previamente. Esta modificación de la dinámica es esencial para inhibir la separación de los compartimentos hifales, por un mecanismo que implica la exclusión de la fosfatasa Cdc14 del septo de las hifas. En los siguientes apartados se discutirán algunos aspectos relevantes de los fenotipos observados en la cepa carente de $\mathrm{Ace} 2^{\mathrm{M}}$ durante el crecimiento filamentoso, así como los posibles mecanismos moleculares implicados en la transmisión de la señal desde $A c e 2^{\mathrm{M}}$ hasta el anillo de septinas y desde el anillo de septinas hasta $A c e 2^{\mathrm{N}}$.

Ace $2^{\mathrm{M}}$ y el posicionamiento del septo. El análisis de las hifas de las cepas deficientes en Ace ${ }^{\mathrm{M}}$ mostró que la distancia entre el primer septo y el cuerpo celular era significativamente superior a la de la cepa silvestre (Fig. 40). Como se ha comentado en la Introducción, tras la emergencia del tubo germinativo las septinas se localizan 
en el ápice formando una estructura conocida como "cap" que se mantiene hasta que la hifa adquiere una longitud determinada. En ese momento, parte de las septinas del "cap" quedan ancladas en las paredes laterales de la hifa y rápidamente se reorganizan para formar un anillo que determina el plano de división donde se ensamblará el septo que divide el cuerpo del primer compartimento hifal (González-Novo et al., 2008; Sudbery et al., 2004). Sin embargo, poco se sabe de los mecanismos que regulan este proceso y si es una señal temporal o espacial la que determina que las septinas queden ancladas en un punto concreto de la membrana. Hasta la fecha, únicamente se ha descrito un mutante que durante la filamentación es incapaz de ensamblar los anillos de septinas, y es el mutante gin $4 \Delta / \Delta$. En este mutante, las septinas se localizan normalmente en la banda basal y en el "cap", pero no forman anillos (Sinha et al., 2007; Wightman et al., 2004). Por tanto, la actividad quinasa de Gin4 es necesaria para la formación de los anillos, habiéndose descrito hasta la fecha dos septinas que son fosforiladas por esta quinasa: Cdc11 y Sep7.

Gin4 fosforila a Cdc11, pero mutantes no fosforilables de Cdc11 son capaces de ensamblar anillos de septinas normales, lo que indica que esta fosforilación no es necesaria para la organización del anillo (Sinha et al., 2007). Más recientemente se ha demostrado que Gin4 fosforila y se asocia con Sep7, aunque no se han identificado los residuos de Sep7 que son modificados (Wightman et al., 2004 Li et al. 2012; Wightman et al., 2004). Además, estos últimos autores también encontraron que Gin4 tiene funciones que son independientes de su actividad quinasa que son esenciales para el ensamblaje del anillo de septinas. Por tanto, una posibilidad es que el defecto en el posicionamiento del septo del mutante que carece de la proteína de membrana dependa de Gin4. EI análisis de la localización de Gin4-GFP en el mutante ace $2 \Delta / \Delta$ indica esta quinasa se localiza en los anillos de septinas como en la cepa silvestre, por lo que Ace2 no parece regular su localización. Sin embargo, podría ser debido a un defecto o retraso en la activación de Gin4, pero no a un bloqueo completo, ya que el anillo de septinas acaba por formarse en la cepa carente de Ace2. Para confirmar esta posibilidad, será necesario analizar la actividad quinasa de Gin4 durante la filamentación en este mutante.

Alternativamente, la mayor distancia del primer septo podría ser debida a un retraso temporal del proceso de ensamblaje del anillo de septinas. Es decir, la ausencia de $\mathrm{Ace} 2^{\mathrm{M}}$ podría producir un alargamiento de alguna de las fases del ciclo celular, como G2, en comparación con la cepa silvestre, por lo que los filamentos podrían crecer durante más tiempo antes de que ocurra la señal que activa la unión de las septinas a las paredes laterales de la hifa. Aunque se sabe que en S. cerevisiae una prolongación de la fase G2 es la responsable de la aparición de pseudohifas y de yemas hiperpolarizadas (Kron et al., 1994), en C. albicans se ha demostrado que la elongación de la hifa no parece estar regulada por alteraciones en la progresión del ciclo celular (Hazan et al., 2002). Ya que el correcto ensamblaje de las septinas es la señal que detecta el "checkpoint" de morfogénesis en S. cerevisiae (Lew y Reed, 1995), cabría la posibilidad de que la parada del ciclo celular fuera debida a la activación de este mecanismo de control mediado por Swe1, permitiendo que la hifa siguiera creciendo. Sin embargo, se ha demostrado que en $C$. albicans este mecanismo de control está restringido exclusivamente al crecimiento en forma de levaduras (Wightman et al., 2004), por lo que tampoco debe ser la causa del aumento en la distancia del primer septo.

Ace $2^{\mathrm{M}}$, la dinámica del anillo de septinas y la inhibición de la separación celular. El análisis de la dinámica del anillo de septinas en las hifas de la cepa deficiente de $A c e 2^{\mathrm{M}}$ mostró que era similar a la de levaduras, ya que no existía intercambio de Cdc10 con el citoplasma. Como consecuencia, uno de los fenotipos más aparentes de las hifas de las cepas que no expresan $A c e 2^{\mathrm{M}}$ es la activación de la separación celular tras 3,5 horas de inducción, produciendo un porcentaje elevado (superior al 20\%) de cuerpos celulares separados de las hifas 


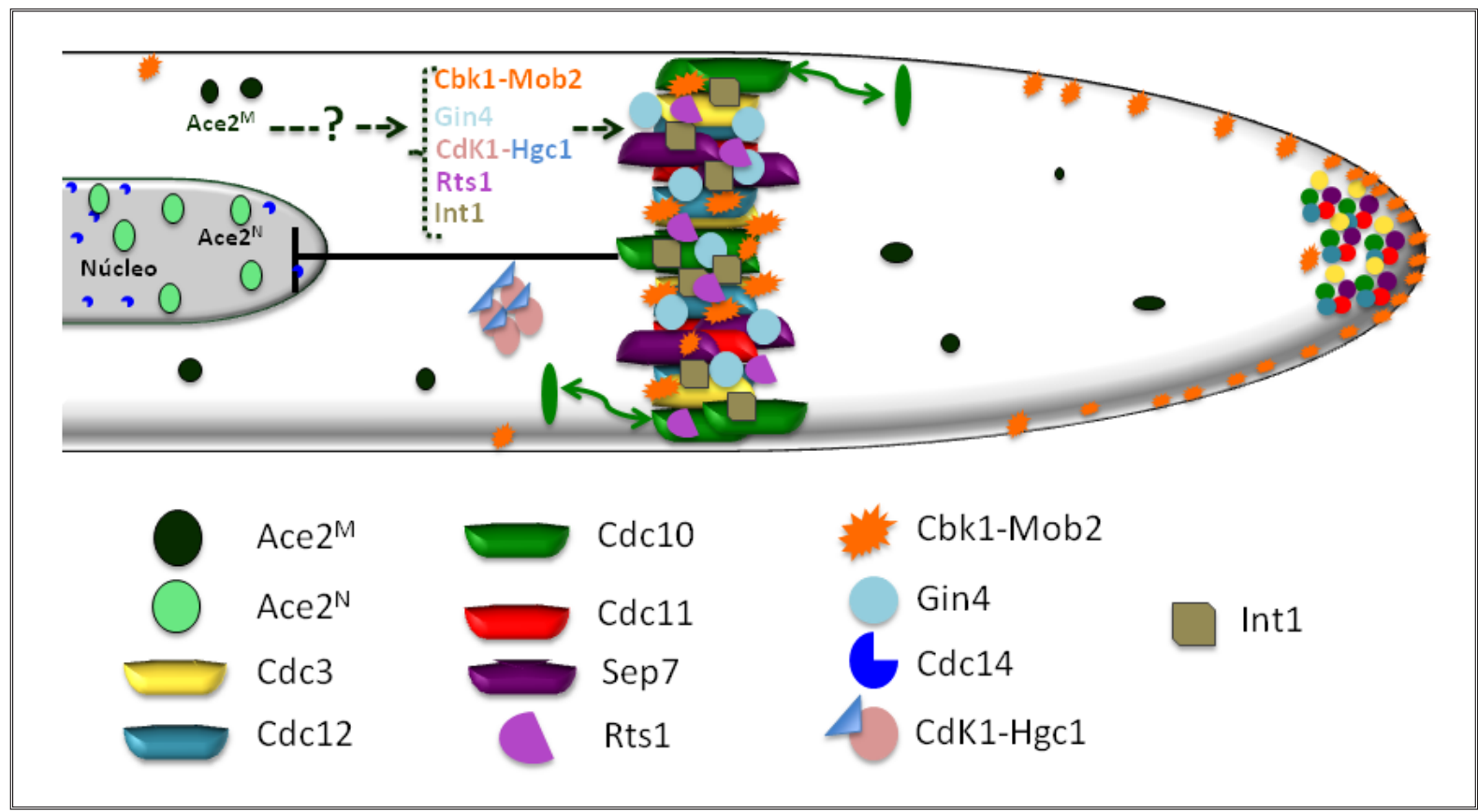

Figura 51. Modelo de la regulación de la separación celular en hifas de $\boldsymbol{C}$. albicans. Las proteínas Hgc1, Sep7 y Ace ${ }^{\mathrm{M}}$ por mecanismos que aún se desconocen, regulan el establecimiento del estado específico de hifas del anillo de septinas, caracterizado por el intercambio de Cdc10 con el citoplasma. Este estado especifico de hifas evita que la fosfatasa Cdc14 se transloque al septo, eliminando así las señales que activarían a $A c e 2^{N}$ presente en el núcleo, con lo que se inhibe la separación de los compartimentos celulares de las hifas.

(Fig. 44). El mutante nulo ace $2 \Delta / \Delta$ presenta los mismos defectos en la dinámica del anillo de septinas, aunque en ningún caso se observan cuerpos celulares aislados. Esto se debe a que este mutante carece no sólo de la forma de membrana, sino también de la forma nuclear que es necesaria para activar la transcripción de los genes implicados en separación. La confirmación de que el fenotipo de separación celular era dependiente de la ausencia de $A c e 2^{\mathrm{M}}$ se obtuvo cuando se insertó la construcción $P M E T 3-A C E 2^{\mathrm{M}}$ en el locus RP10 del mutante ace $2 \triangle / A C E 2^{N}$, pues en esta cepa el porcentaje de separación de las hifas era similar al de la cepa silvestre. Además, la inserción de una construcción similar que contenía la proteína Ace $2^{\mathrm{M}}-\Delta \mathrm{Zn}$ en el mismo locus también era capaz de complementar los defectos del mutante, lo que confirma claramente que la actividad transcripcional no es necesaria para la función de $A c e 2^{\mathrm{M}}$.

La pregunta que se plantea ahora es ¿Cuál es el mecanismo molecular por el que Ace ${ }^{M}$ regula la dinámica del anillo de septinas y su conversión a la forma específica de hifas? A pesar de que los resultados obtenidos no permiten responder a esta pregunta con claridad, se pueden plantear varias hipótesis que necesariamente deberán ser validadas experimentalmente para comprobar si son ciertas. Todas ellas se centran en proteínas conocidas, que previamente se ha descrito que controlan la estabilidad y/o la estructura del anillo de septinas.

En primer lugar, un posible candidato es la quinasa Gin4 que recientemente se ha descrito que interacciona con las septinas y fosforila a Sep7 (Li et al., 2012a). Como se ha discutido anteriormente, la actividad quinasa de Gin4 es necesaria para la reorgnización de las septinas desde el "cap" a anillos, por lo que la modificación de la dinámica del anillo de septinas dependiente de $A c e 2^{\mathrm{M}}$ podría estar mediada por la quinasa Gin4. Ace $2^{\mathrm{M}}$ no es necesaria para la correcta localización de Gin4 en los septos, pero podría regular o modular la actividad quinasa de Gin4 o la función de Gin4 recientemente descrita que es independiente de su actividad quinasa, y este defecto podría estar relacionado con el defecto de posicionamiento del primer septo.

Otro posible candidato podría ser la proteína Int1, que es el ortólogo de Bud4 de S. cerevisiae y Mid2 de $S$. 
pombe. Estas proteínas pertenecen a la familia de las anillinas, y en todos los casos están implicadas en la organización del anillo de septinas. En S. cerevisiae, Bud4 se localiza en el anillo de septinas y es necesario para su duplicación y desensamblaje al final de citoquinesis y su función está regulada por fosforilación por Cdc28 (Eluère et al., 2012; Sanders y Herskowitz, 1996). En S. pombe, los mutantes mid2A presentan defectos en la organización y estabilidad del anillo de septinas. Además, mientras que en una cepa silvestre las septinas se ensamblan de forma estable en el anillo, en el mutante mid2 $\Delta$ las septinas se intercambian unas 30 veces más rápidamente (Berlin et al., 2003; Tasto et al., 2003). En C. albicans, Int1 es importante para la morfogénesis de la hifa, adherencia y virulencia (Gale et al., 1998). Las cepas mutantes int $1 \Delta / \Delta$ presentan defectos en el ensamblaje de los anillos de septinas tanto en hifas como en levaduras (Gale et al., 2001). La proteína localiza junto con las septinas y co-inmunoprecipita con Cdc11 y Cdc12. Su expresión en S. cerevisiae produce células hiperpolarizadas en las que las septinas forman espirales alargadas en la periferia de estas células alargadas (Asleson et al., 2001; Gale et al., 2001). Por tanto, Ace ${ }^{\mathrm{M}}$ podría controlar la transición del anillo de septinas a través de Int1. Sin embargo, a pesar de que la organización de las septinas en las hifas de los mutantes int $1 \Delta / \Delta$ es defectuosa, el análisis de la dinámica del anillo en esta cepa mediante FRAP usando Cdc10-GFP mostró que el intercambio de Cdc10 es similar al de la cepa silvestre (datos no mostrados), indicación de que se han convertido al estado especifico de hifas. Por tanto, Int1 parece ser necesario para la correcta organización del anillo de septinas, pero no para la modificación de su dinámica, por lo que no parece lógico pensar que $A c e 2^{\mathrm{M}}$ regule el anillo a través de esta integrina.

En tercer lugar, la regulación de la dinámica del anillo podría estar mediada por Rts1, la subunidad reguladora de la fosfatasa PP2A, puesto que es otra de las proteínas reguladoras del anillo de septinas en S. cerevisiae y C. albicans. En S. cerevisiae, PPA2-Rts1 se localiza en el cuello de la célula después de la división del anillo de septinas y es necesario para su desensamblaje al final de citoquinesis (Dobbelaere et al., 2003). En C. albicans, Rts1 también controla el ensamblaje de los anillos de septinas en hifas y levaduras. Los mutantes $r t s 1 \Delta / \Delta$ presentan anillos asimétricos tras su duplicación en levaduras (Caballero-Lima, 2009). En las hifas, las septinas inicialmente se localizan en el "cap" y posteriormente quedan ancladas en la membrana lateral como en la cepa silvestre, pero son incapaces de madurar y formar un anillo normal. En su lugar, aparecen estructuras aberrantes como anillos incompletos, espirales o barras paralelas al eje longitudinal de la hifa, que en muchos casos son capaces de duplicarse antes de la septación aunque los anillos duplicados tampoco son normales (Jaime Correa y Carlos R. Vázquez, resultados sin publicar). Al mismo tiempo, Sep7 presenta un mayor grado de fosforilación que en la cepa silvestre, lo que indica que Rts1 es necesaria para eliminar alguna fosforilación de Sep7 y permitir la correcta maduración del anillo de septinas en las hifas (Jaime Correa, comunicación personal). Sin embargo, el análisis de la dinámica de las estructuras de se septinas que se forman en las hifas del mutante rts $1 \Delta / \Delta$ mediante FRAP indica que a pesar de los defectos morfológicos, la tasa de intercambio de Cdc10 es similar, o incluso superior, a la de la cepa silvestre (Jaime Correa y Carlos R. Vázquez, resultados sin publicar). Estos resultados parecen descartar a Rts1 como efector de $A c e 2^{\mathrm{M}}$ en la regulación de la dinámica del anillo, pero al mismo tiempo ponen de manifiesto que existen dos procesos independientes en la formación del anillo de septinas de las hifas. La formación y maduración de los anillos depende de Gin4, Rts1 e Int1, mientras que la conversión de los mismos al estado específico de hifas es independiente de estos reguladores (al menos de Int1 y Rts1) pero depende de Ace ${ }^{\mathrm{M}}$, Sep7 y Hgc1.

Si la conversión del anillo de septinas en hifas al estado HSS es una ruta independiente de otras proteínas implicadas en la organización y mantenimiento de la estructura del anillo, cabe pensar que Ace ${ }^{\mathrm{M}}$ sería un nuevo componente de esta ruta, en la que previamente se ha descrito que participan Hcg1 y Sep7. Observaciones preliminares indican que la composición del anillo de septinas es diferente en la cepa silvestre y en el mutante 
ace $2 \Delta / \Delta$. Así, el análisis de las septinas presentes en el anillo de estas dos cepas usando Cdc10-GFP para inmunoprecipitarlas parece indicar que existe una reducción en la cantidad de Sep7 en el mutante ace $2 \Delta / \Delta$ en comparación con la cepa silvestre, especialmente en hifas (A. González-Novo, datos no publicados). En S. cerevisiae se ha descrito que cuando Shs1 sustituye a Cdc11 en el extremo de los octámeros, éstos no se ensamblan en forma de filamentos, sino que se asocian lateralmente en racimos curvados que forman anillos (Garcia et al., 2011). Puesto que el cambio en la dinámica del anillo de septinas en las hifas de C. albicans depende de Sep7/Shs1, es posible que esté asociado a un aumento en la cantidad de octámeros que contienen Sep7 frente a los que contienen Cdc11, lo que al mismo tiempo produciría un cambio en las estructuras de orden superior que se forman en hifas respecto a levaduras. Por tanto, la reducción en la cantidad de Sep7 observada en el mutante ace $2 \Delta / \Delta$ modificaría las propiedades del anillo. Será necesario comprobar si el defecto en la cantidad de Sep7 presente en los anillos de septinas también ocurre en la cepa ace $2 \Delta / A C E 2^{N}$ para poder afirmar que es debido específicamente a la ausencia de $A c e 2^{\mathrm{M}}$. Teniendo en cuenta los resultados previamente descritos que demuestran que la fosforilación de Sep7 varía dependiendo del estado morfogenético y que la conversión de los anillos al HSS depende de la ciclina Hgc1, cabría la posibilidad de que Ace ${ }^{\mathrm{M}}$ pudiera de alguna manera (directa o indirecta) regular la fosforilación de Sep7. Esta hipótesis se basa en el hecho de que un mutante $h g c 1 \Delta / \Delta$ la dinámica de los anillos es similar a la del mutante $\operatorname{sep} 7 \Delta / \Delta$ y a la del mutante que carece de $A c e 2^{\mathrm{M}}$. No es factible pensar que Ace $2^{\mathrm{M}}$ pueda actuar como un andamio para el ensamblaje de las septinas que regule directamente la interacción de Sep7 con el resto del complejo, pues esta proteína no se localiza en la zona donde se ensamblan los anillos de septinas. Sin embargo, Ace $2^{\mathrm{M}}$ presenta un elevado número de posibles sitios de fosforilación por Cdc28, cuya fosforilación/defosforilación podría ser crucial en la regulación de su función en hifas y/o levaduras o alternativamente, podría formar un complejo más o menos estable con Cdc28-Hgc1 que controlara espacialmente su actividad. Para confirmar o desmentir estas posibilidades, será necesario analizar la contribución de los sitios de fosforilación de $A c e 2^{\mathrm{M}}$ en la regulación de la dinámica del anillo de septinas mediante experimentos de mutagénesis puntual y determinar mediante inmunoprecipitación si Ace ${ }^{\mathrm{M}}$ y el complejo Cdc28-Hgc1 interaccionan físicamente.

Respecto a la segunda parte de la ruta, la señal que inhibe la actividad de $A c e 2^{\mathrm{N}}$ dependiente del estado dinámico del anillo de septinas, es muy factible que implique al complejo Cbk1-Mob2, que también regule la localización y actividad de Ace2 en levaduras y a la fosfatasa Cdc14. Recientemente Gutiérrez-Escribano y colaboradores demostraron que la fosforilación sobre Mob2 por parte de Cdc28 es necesaria para inhibir la separación celular durante el crecimiento hifal (Gutiérrez-Escribano et al., 2011). Mob2 posee 4 sitios consenso de fosforilación por Cdc28 que cuando se cambian a Ala generan mutantes con graves defectos en la morfogénesis de la hifa y al mismo tiempo también activan la separación celular. Experimentos preliminares en los que se ha analizado la dinámica del anillo de septinas en la cepa mob2-4A mediante FRAP indican que no existen defectos significativos, siendo la tasa de intercambio de Cdc10 similar a la de la cepa silvestre. Esto indica que Cbk1-Mob2 no parecen regular la dinámica del anillo de septinas, y que la fosforilación de los 4 sitios de Mob2 es necesaria para inhibir la separación celular en hifas. Estas observaciones cuadran perfectamente con los resultados descritos previamente que indicaban que la fosfatasa Cdc14 está excluida del septo en las hifas (González-Novo et al., 2008), pues al ser Cdc14 la fosfatasa que revierte las fosforilaciones de la actividad CDK su incapacidad para unirse al septo permitiría que Mob2 se mantuviera fosforilado en hifas. En el mutante $\operatorname{sep} 7 \Delta / \Delta$, la incorporación de Cdc14 al septo permitiría la defosforilación de Mob2 y la activación del complejo Cbk1-Mob2, y por tanto, la activación de la separación celular dependiente de Ace2 ${ }^{N}$. Queda todavía por determinar si Cbk1-Mob2 desempeñan algún papel en la regulación de $A c e 2^{\mathrm{M}}$, aunque no sea en la regulación de la dinámica del anillo de septinas. Esta posibilidad se basa en el hecho de que $A c e 2^{\mathrm{M}}$ también interacciona físicamente con Cbk1-Mob2 en ensayos de 
inmunoprecipitación y en la existencia de un sitio de fosforilación de este complejo inmediatamente detrás de la región transmembrana, que podría desempeñar algún papel en la regulación de $A c e 2^{\mathrm{M}}$.

Todos los resultados de la presente Memoria indican que C. albicans ha desarrollado un mecanismo especifico para regular la dinámica del anillo de septinas durante la filamentación que implica la existencia de dos formas diferentes del factor de transcripción Ace2, una de las cuales actúa como activador transcripcional mientras que la otra regula su actividad de forma indirecta. Aunque todavía se desconocen los mecanismos moleculares implicados en esta ruta de regulación, los resultados genéticos indican claramente que las dos proteínas tienen funciones diferentes, lo que supone un mecanismo desconocido hasta la fecha en otros organismos de regulación de la actividad transcripcional. 


\section{Conclusiones}





\section{CONCLUSIONES}

1. El gen ACE2 de Candida albicans codifica para dos proteínas distintas, necesarias para regular la separación celular en las distintas morfologías. Estas dos formas se originan por el uso de dos codones de inicio de la traducción alternativos que se encuentran en la misma fase de lectura y dan lugar a dos polipéptdos que difieren en 54 aminoácidos en el extremo amino.

2. Se han identificado varios puntos de inicio de la transcripción en el gen ACE2, que dan lugar a dos poblaciones de mRNAs diferentes y cuya traducción podría generar las dos isoformas de la proteína. La población más abundante (denominada mRNA corto) se produce por el inicio de la transcripción en tres puntos diferentes situados entre el AUG1 y el AUG2. Se ha identificado también un mensajero de mayor tamaño que contiene ambos AUGs, que podría ser específico de uno de los dos alelos del gen ACE2.

3. La traducción de los distintos RNAs mensajeros genera dos formas de la proteína, denominadas $A c e 2^{\mathrm{N}}$ y Ace $2^{\mathrm{M}}$, presentan diferentes características bioquímicas, de localización subcelular y función.

4. De las dos formas de Ace 2 descritas en esta Memoria, Ace $2^{\mathrm{N}}$ se encuentra predominantemente en el núcleo tanto en levaduras como en hifas y desempeña la función de factor de transcripción, activando la expresión de los genes necesarios para la separación celular y la respiración.

5. Ace $2^{\mathrm{M}}$ contiene 54 aminoácidos adicionales en el extremo amino que incluyen una región altamente hidrofóbica que actúa como un verdadero dominio transmembrana, siendo capaz de dirigir la proteína a la ruta secretora. Gracias a esta región, $A c e 2^{\mathrm{M}}$ se asocia con membranas intracelulares y localiza en vesículas intracelulares.

6. Ace $2^{\mathrm{M}}$ no parece desempeñar ninguna función relevante durante el crecimiento en forma de levaduras, pero es esencial para el correcto posicionamiento del anillo de septinas en hifas y para inhibir la separación celular durante esta forma de crecimiento.

7. Ace $2^{\mathrm{M}}$ parece ser un nuevo miembro del grupo de proteínas necesarias para la conversión del anillo de septinas a su estado específico de hifas, junto con las proteínas Cdc28-Hgc1 y Sep7 previamente descritas. La actividad transcripcional de $A c e 2^{\mathrm{M}}$ no es necesaria para esta función. 

6. Materiales y Métodos 



\subsection{MICROORGANISMOS UTILIZADOS}

Para el desarrollo de este trabajo de investigación se utilizaron diferentes estirpes de la bacteria Escherichia coli y del hongo ascomycota Candida albicans; sus características genéticas así como su procedencia se detallan en la Tabla 2. C. albicans fue el microorganismo elegido como modelo para estudiar los procesos de morfogénesis, crecimiento y división celular descritos en este trabajo; todas las cepas construidas de este microorganismo parten del fondo genético BWP17 (Wilson et al., 1999).

La cepa DH5a de E. coli fue empleada para los experimentos rutinarios de clonación molecular y como hospedador de los plásmidos utilizados. La conservación de las cepas de levaduras se realizó a $-80^{\circ} \mathrm{C}$ en crioviales con glicerol al $25 \%$, mientras que las cepas bacterianas fueron conservadas en glicerol al $50 \%$.

\subsection{MEDIOS DE CULTIVO Y CONDICIONES DE CRECIMIENTO}

Los medios de cultivo fueron preparados con agua millo-Rho y esterilizados en autoclave. Así mismo, los medios sólidos fueron preparados agregando agar al $2 \%$ a los medios líquidos correspondientes.

\subsubsection{Crecimiento de C. albicans.}

C. albicans fue cultivada rutinariamente a $28^{\circ} \mathrm{C}$ en YPD (Bacto Peptona $2 \%$, dextrosa $2 \%$ y extracto de levaduras $1 \%$ ) o medio mínimo YNB (dextrosa $2 \%$ y $6,7 \%$ de YNB), suplementado con aminoácidos según los requerimientos de cada cepa, a concentraciones finales de $40 \mathrm{mg} / \mathrm{L}$ para arginina e histidina y de $80 \mathrm{mg} / \mathrm{L}$ para uridina. El crecimiento hifal de $C$. albicans fue inducido en medio YPD ó YNB con suero fetal bovino al $10 \%$ a $37^{\circ} \mathrm{C}$. Los experimentos que requerían el apagado de genes regulados por el promotor PMET3 fueron realizados en medio YNB suplementado con metionina y cisteína a una concentración final de 2,5 mM.

\subsubsection{Crecimiento de E. coli.}

Las estirpes bacterianas de E. coli crecieron a $37^{\circ} \mathrm{C}$ en medio Luria Broth (LB), compuesto por bactotriptona al 1 $\%$, extracto de levadura al $0,5 \%$ y cloruro de sodio al $1 \%$. La selección de clones se realizó mediante siembra en LB suplementado con $100 \mu \mathrm{g} / \mathrm{ml}$ de ampicilina.

\subsection{PROCEDIMIENTOS GENERALES DE CLONACIÓN MOLECULAR}

\subsubsection{Obtención de DNA plasmídico.}

Para la extracción rápida y a pequeña escala de DNA plasmídico de $E$. coli se empleó el método de lisis alcalina (Sambrook, 3AD). Cuando se necesitó de una alta pureza y mayor concentración del DNA, se recurrió al uso de columna de intercambio iónico Quantum Prep ${ }^{\circledR}$ Plasmid Miniprep Kit (BioRad) según las indicaciones del fabricante.

\subsubsection{Obtención de DNA genómico de C. albicans.}

El método de extracción fenólica con lisis mecánica fue usado para aislar el DNA de alto peso molecular. Para ello se inocularon $5 \mathrm{ml}$ de YPD con la levadura y se incubó toda la noche a $28^{\circ} \mathrm{C}$. Tras recuperar las células por centrifugación, se resuspendieron en 0,2 ml de Tampón de rotura (Tritón X-100 $2 \%$, SDS 1\%, NaCl 100 mM, Tris-HCl pH 8,0 10 mM y EDTA $1 \mathrm{mM}$ ), 0,2 ml fenol-cloroformo-isoamílico (25:24:1) y 0,3 gr de bolitas de vidrio (0,4 mm; Sigma-Aldrich, St Louis MO); esta mezcla se agitó 4 minutos en vórtex a máxima potencia. Al finalizar la ruptura, se añadieron $0,2 \mathrm{ml}$ de TE $1 \mathrm{X}$ a las células rotas y se separó la fase acuosa de la fenólica centrifugando 5 minutos a $13000 \mathrm{rpm}$. La fase acuosa fue transferida a un nuevo tubo que contenía $1 \mathrm{ml}$ de etanol al 100\% para después centrifugar 2 minutos a $13000 \mathrm{rpm}$. El precipitado fue resuspendido en $400 \mathrm{ml}$ de TE $1 \mathrm{X}$ y tratado con $30 \mu \mathrm{g}$ de RNAasa 15 minutos a $37^{\circ} \mathrm{C} .10 \mu \mathrm{l}$ de acetato de amonio $2,5 \mathrm{M}$ y $1 \mathrm{ml}$ de etanol al $100 \%$ fueron añadidos y mezclados por inversión para precipitar el DNA que fue concentrado por centrifugación a $13000 \mathrm{rpm}$ durante 2 minutos y secado a temperatura ambiente hasta la total evaporación del etanol, para ser resuspendido finalmente en $0,1 \mathrm{ml}$ de TE $1 X$. 


\subsubsection{Reacción en cadena de la polimerasa (PCR).}

La amplificación de fragmentos de DNA se hizo mediante reacción en cadena de la polimerasa en un termociclador MiniciclerTM (MJ Reasearch), usando diferentes polimerasas como KAPA HIFI, KAPA 2GTM Robust HotStart (Nippon Genetics, Düren, Germany) y Go Taq (Promega Madison, Wisconsin) según la fidelidad requerida. Para todas las enzimas, la reacción fue realizada según se indicaba en las instrucciones de la casa comercial. Por lo general, el DNA fue desnaturalizado durante 5 minutos a $95^{\circ} \mathrm{C}$ seguido de $30-35$ ciclos con los siguientes pasos: 30 segundos a $95^{\circ} \mathrm{C}, 30$ segundos a la temperatura de anillamiento específica del oligonucleótido empleado, 1 minuto a $72^{\circ} \mathrm{C}$ de extensión por cada kilobase de DNA a amplificar, y para finalizar la reacción 10 minutos de extensión a $72^{\circ} \mathrm{C}$. Los oligonucleótidos usados están enumerados en la Tabla 3.

\subsubsection{Manipulación del DNA.}

Los procedimientos generales de manipulación del DNA se encuentran recogidos en el manual de laboratorio de Sambrook y Colaboradores (2001), excepto en aquellas ocasiones en las que se utilizaron "kits" comerciales para las que se siguieron las indicaciones de la casa comercial. Todos los fragmentos de DNA obtenidos por PCR o por tratamiento con enzimas de restricción fueron analizados en geles de agarosa (SeaKem ${ }^{\circledR}$ ME Agarose, FMC Bio Products) y teñidos con bromuro de etidio $(0,5 \mathrm{mg} / \mathrm{ml}$ ), preparados en tampón TAE (Tris-acetato $40 \mathrm{mM}$, EDTA $1 \mathrm{mM}, \mathrm{pH}$ 7,5-7,8) a concentraciones que oscilaban entre 0,8 y 1,5\%, según el tamaño de los fragmentos a separar. El aislamiento y purificación de los fragmentos específicos de DNA obtenidos por PCR o por restricción con encimas, se realizó con el kit NucleoSpin ${ }^{\circledR}$ Extract II (Macherey-Nagel, Dürem, Germany). Para la clonación de fragmentos de DNA se usaron enzimas de restricción así como la ligasa del fago T4 de la casa comercial Roche. La fosfatasa alcalina fue proporcionada por Boehringer Mannhein.

\subsubsection{Detección de los sitios de inicio de transcripción (RACE).}

Para la clonación de los extremos 5' del mensajero de ACE2, se realizo la técnica RACE ("Rapid Amplification of cDNA Ends") con el "Kit" ExactSTART TM Eukaryotic mRNA 5'-\&3'-RACE (EPICENTRE Biotechnologies) siguiendo las recomendaciones de la casa comercial. Primero, se realizó un tratamiento con fosfatasa alcalina a una muestra de RNA total, con el fin de remover los grupos fosfatos de RNAs no protegidos (aquellos que no contienen el "cap" en el extremo 5'), con el fin de que no interfieran con la obtención de los RNAs mensajeros (aquellos que si están protegidos por el "cap"). Las muestras fueron posteriormente tratadas con pirofosfatasa ácida de tabaco con el fin de remover el "cap" del extremo 5', para de este modo obtener RNAs monofosfato en su extremo 5', a los cuales posteriormente se les ligó un oligonucleótido aceptor que contenía un sitio de iniciación de PCR para las posteriores reacciones de amplificación. Después, se realizó una retrotranscripción para obtener cDNAs a partir de los RNAs 3'-poliadenilados. En este paso se usó un oligonucleótido específico de ACE2 con el fin de restringir la obtención de cDNAs a aquellos exclusivos de este gen. Finalmente, se realizó la síntesis de la doble cadena de DNA mediante una PCR convencional.

Los productos obtenidos tras el desarrollo de esta técnica, fueron clonados con el "kit" StratClone Blunt PCR Cloning (Agilent Technologies) según indicaciones de la casa comercial para su posterior secuenciación y análisis.

\subsection{CONSTRUCCIÓN DE CEPAS}

La deleción de genes de $C$. albicans así como el marcaje de proteínas con diferentes fluoróforos y epítopos fue realizada con el método mediado por PCR usando los módulos pFA (Gola et al., 2003; Schaub et al., 2006). Los transformantes fueron seleccionados en medio YNB suplementado con los aminoácidos necesarios según sus auxotrofías, o en YEPD con clonNAT a una concentración final de $200 \mathrm{mg} / \mathrm{ml}$ (Werner BioAgents, Jena, Germany) para seleccionar cepas SAT1. Las cepas que contenían proteínas marcadas con algún fluoróforo o epítopo se consideraban funcionales en tanto que se observase un crecimiento normal en un fondo heterocigoto.

La construcción de cepas carentes de un gen determinado se llevo a cabo usando la técnica de reemplazamiento genético (Rothstein, 1991), la cual se basa en la transformación integrativa de las moléculas lineales de DNA. Esta estrategia consiste en el uso de un casete de transformación obtenido mediante PCR (a partir de DNA 
plasmídico de algún de los módulos pFA), el cual contiene un marcador de selección flanqueado por las regiones no codificantes 3' y 5' del gen para dirigir la integración, regiones que provenían de oligonucleótidos de 100 pb. Estas regiones homologas permiten la recombinación del fragmento con uno de los alelos del gen a delecionar, sustituyendo el ORF del mismo por el marcador de selección. Las cepas que no fueron construidas mediante esta estrategia, se hicieron utilizando fragmentos de DNA linearizados con encimas de restricción, a partir de plásmidos construidos sobre el vector de clonación pGEM ${ }^{\circledR}-\mathrm{T}$ (Promega). Todas las cepas fueron confirmadas por PCR usando oligonucleótidos obtenidos de la casa comercial Biomers.net (UIm. Germany) y se encuentran recogidos en la Tabla 3.

\subsubsection{Transformación de $C$. albicans.}

Dos metodologías fueron usadas para la obtención de las diferentes cepas del hongo:

Transformación con Acetato de litio. La transformación química se realizó como ha sido previamente descrito (Walther y Wendland, 2003), con algunas modificaciones. Los cultivos celulares de las cepas a transformar que habían crecido durante toda la noche se diluyeron en $25 \mathrm{ml}$ de medio fresco a una densidad óptica a 600nm $\left(O D_{600}\right)$ de 0,3 e incubadas con agitación a $28^{\circ} \mathrm{C}$ durante $3-4$ horas hasta alcanzar una $\mathrm{OD}_{600}$ de $1,4-1,8$. Las células fueron recogidas, lavadas con $25 \mathrm{ml}$ de agua destilada estéril y resuspendidas en 1,5 $\mathrm{ml}$ de solución de acetato de litio (Acetato de Litio 100 mM, Tris- $\mathrm{HCl} 10$ mM, EDTA 1 mM). La mezcla de transformación fue hecha agregando $100 \mu \mathrm{l}$ de células, $100 \mu \mathrm{g}$ de DNA monocatenario (DNA “carrier", 2 mg/ml), 1-5 $\mathrm{gg}$ de DNA a clonar y $600 \mu \mathrm{l}$ de solución PEG/LiAc (PEG 4000 al 50\% en solución de acetato de litio). Esta mezcla fue incubada toda la noche en agitación a $28^{\circ} \mathrm{C}$ antes de someterla a un choque térmico a $44^{\circ} \mathrm{C}$ durante 15 minutos. Las células fueron entonces lavadas y sembradas en medios selectivos.

Transformación por electroporación. El protocolo de electroporación para C. albicans fue el descrito por (Reuss et al., 2004). A partir de un pre-cultivo en YEPD de C. albicans, se realizó una dilución a 0,4 OD 600 en $25 \mathrm{ml}$ de medio fresco en agitación a $28^{\circ} \mathrm{C}$ hasta llegar a 1,4-1,6 $\mathrm{OD}_{600}$. Las células fueron recogidas por centrifugación y resuspendidas en $25 \mathrm{ml}$ de solución de acetato de litio (acetato de litio 0,1 M pH 7,5, Tris- $\mathrm{HCl} 10 \mathrm{mM}$, EDTA $1 \mathrm{mM} \mathrm{pH} \mathrm{7,5} \mathrm{y} \mathrm{DTT} 10 \mathrm{mM}$ ) e incubadas por 1 hora a temperatura ambiente. Las células fueron entonces lavadas 3 veces con agua estéril fría y una vez con sorbitol $1 \mathrm{M}$. Estas células competentes fueron recogidas por centrifugación y resuspendidas en $160 \mu \mathrm{l}$ de sorbitol $1 \mathrm{M}$. La mezcla de electroporación, que contenía $50 \mu \mathrm{l}$ de la suspensión de células competentes y 1-5 $\mu \mathrm{g}$ de DNA, fue mantenida durante 5 minutos en hielo; Entonces, se llevo a cabo la electroporación de las células competentes en un electroporador Gene pulser ${ }^{\circledR}$ de Biorad (cubetas de $0,2 \mathrm{~cm}$ a 1,5 kV). Después de la electroporación, las células fueron lavadas con $1 \mathrm{ml}$ de sorbitol y sembradas en medios selectivos.

Para los dos tipos de transformaciones cuando fue usado el marcador SAT1, las células fueron incubadas en 1 $\mathrm{ml}$ de YEPD a $28^{\circ} \mathrm{C}$ en agitación con el fin de permitir su recuperación antes de ser sembradas en el medio con la nourseotricina.

\subsubsection{Transformación de $E$. coli.}

La transformación de la cepa bacteriana DH5a se realizó según el procedimiento descrito por Kushner (Kushner, 1978), basado en el choque térmico y mediante el uso de kit StrataClone Blunt PCR Cloning ${ }^{\circledR}$ (Agilent Technologies, Santa Clara, CA) siguiendo las instrucciones de la casa comercial.

\subsection{EXTRACCIÓN DE RNA Y RT-PCR CUANTITATIVA}

Para la extracción del RNA se recogió un cultivo celular en fase logarítmica y se almacenó a $80^{\circ} \mathrm{C}$. Un total de $50 \mathrm{mg}$ de células fueron lisadas con 0,3 gr de bolitas de vidrio (0,4 mm; Sigma-Aldrich, St Louis MO) en una FastPrep FR120 (Savant, Bio101) en presencia de $50 \mu \mathrm{l}$ de TRIzol ${ }^{\circledR}$ Reagent (Invitrogen, Paisley, UK). El RNA total fue extraído siguiendo las instrucciones de la casa fabricante. La cantidad, calidad e integridad del RNA fueron analizados en Bioanalizador 2100 (Agilent). La síntesis del cDNA fue realizada con el sistema SupersScript II First- 
Strand Synthesis (Invitrogen, Paisley, UK) usando oligo-(dT), partiendo de $3 \mu \mathrm{g}$ de RNA total previamente tratado con DNAasa I (Invitrogen, Paisley, UK). Los ensayos de PCR cuantitativa se realizaron usando SYBR ${ }^{\circledR}$ Premix Ex Taq (Takara bio Inc. Shiga, Japan). Para cada reacción se usó $1 \mu \mathrm{l}$ de cDNA. Los ensayos de qPCR fueron hechos por duplicado llevando a cabo 40 ciclos (desnaturalización inicial de 45 segundos a $95^{\circ} \mathrm{C}, 40$ ciclos de 5 segundos a $95^{\circ} \mathrm{C}, 31$ segundos a $60^{\circ} \mathrm{C}$, un paso de disociación de 15 segundos a $95^{\circ} \mathrm{C}, 1$ minuto a $60^{\circ} \mathrm{C}$ y 15 segundos a $95^{\circ} \mathrm{C}$ ). Se usó un termociclador Applied Biosystems 7300 Real-Time PCR System (Applied Biosystems, Carlsbad, CA). La cuantificación de la expresión se realizó usando el método de la curva estándar.

\subsection{EXTRACCIÓN, DETECCIÓN Y ANÁLISIS DE PROTEÍNAS}

\subsubsection{Extracción.}

Los extractos proteicos fueron preparados a partir de cultivos celulares en fase exponencial de crecimiento en medio líquido apropiado según el experimento a realizar. 1,6 × 10 de células fueron resuspendidas en $200 \mu \mathrm{l}$ de tampón de lisis $B 70$ (HEPES 50 mM, AcK 70 mM NaF 1mM, $\beta$-glicerolfosfato $20 \mathrm{mM}$, Acetato de magnesio $5 \mathrm{mM}$, Triton X-100 0,1\%, glicerol 10\%, PMSF 1 mM, DTT $1 \mathrm{mM}$ ) el cual contenía el cóctel inhibidor de proteasas libre de EDTA de Roche (Roche, Indianapolis, USA), y se añadieron 0,3 gr de bolitas de vidrio (0,4 mm; Sigma-Aldrich, St Louis MO). La rotura de las células se realizó en una FastPrep FR120 (Savant, Bio101), empleando dos pulsos de 30 segundos a una potencia de 5,5. Los extractos proteicos se recuperaron agujereando la base del eppendorf y centrifugando sobre otro eppendorf limpio. Los extractos fueron clarificados centrifugando a 5000 rpm durante 10 minutos a $4^{\circ} \mathrm{C}$. La determinación de la concentración de proteína se realizo con el kit Bio-Rad Dc Protein assay, cuantificado cada muestra por duplicado, tomando como referencia una recta patrón de BSA (0-1 $\mu \mathrm{g} / \mathrm{ul})$.

\subsubsection{Separación electroforética e inmunodetección de proteínas (Western-blot).}

Las proteínas fueron separadas mediante electroforesis en geles de poliacrilamida, usando el sistema "NUPAGE ${ }^{\circledR}$ Novex Bis-Tris gels" (Invitrogen). Entre 50 y $100 \mu \mathrm{g}$ de cada extracto proteico fueron cargados en condiciones desnaturalizantes o no desnaturalizantes según el ensayo a realizar, en geles Bis-Tris de gradientes (4-12\%), en Buffer MOPS según recomendaciones del fabricante.

Una vez separadas las proteínas, se transfirieron a una membrana de PVDF P-Hybond (GE Healthcare), usando el sistema de transferencia "X-Cell Sure Lock Mini-Cell System" (Invitrogen) a 30-40 voltios constantes durante 60-90 minutos. Después de la transferencia, las membranas fueron lavadas por 10 minutos con solución PBS 1X-Tween 0,1\% (PBS-T) y posteriormente bloqueadas durante al menos 1 hora en solución de bloqueo (leche desnata en polvo al 5\% en PBS-T). Los anticuerpos primario y secundario fueron incubados en solución de bloqueo durante al menos una hora, según condiciones que fueron estandarizadas para cada uno de ellos y las recomendaciones de la casa comercial. La detección de los complejos antígenos-anticuerpo se realizó usando la detección de la actividad peroxidasa ligada al anticuerpo secundario mediante quimioluminiscencia ( $E C L$ detection, de GE Helthcare ó Supersignal West Femto kit de Pierce Biotechnologies, Rockford USA) la cual impresiona las películas fotosensibles (Hyperfilm ${ }^{T M}$ MP, GE Healthcare). Los anticuerpos usados en este trabajo se enlistan en la Tabla 4.

\subsubsection{Inmunoprecipitación de proteínas.}

La preparación de extractos celulares para inmunoprecipitación se llevó a cabo siguiendo el protocolo de extracción de proteínas antes descrito, seguido de la incubación de los lisados con bolas magnéticas que llevan unidos los anticuerpos correspondientes ( $\mu \mathrm{MACS}^{\circledR} \mathrm{HA}$, myc o GFP, Tagged Protein Isolation kit, Miltenyi Biotec), durante 30 min a $4^{\circ} \mathrm{C}$ en agitación. Esta mezcla fue cargada en las columnas de separación (MACS ${ }^{\circledR}$ Separation Colums, Miltenyi Biotec), seguido de 4 lavados con el tampón B70 y un lavado final con el "buffer" de lavado 2. Las proteínas retenidas en las columnas fueron eluídas con el tampón de elución proporcionado en el "kit".

Para saber si algunas proteínas presentaban diferentes estados de fosforilación, se realizaron tratamientos con $\lambda$ fosfatasa (New England Biolabs, Ipswich, MA) sobre las proteínas (extraídas en tampón B70 sin NaF ni $\beta$-glicerol fosfato) que se encontraban retenidas en las columnas magnéticas después de los 4 lavados con el "buffer". 
Los western blots para las dos técnicas se realizaron siguiendo el protocolo anteriormente descrito. Para el caso de la co-inmunoprecipitación, tras el revelado con el primer anticuerpo se les realizó a las membranas un "stripping" con glicina $200 \mathrm{mM} \mathrm{pH} \mathrm{2,3.}$

\subsubsection{Fraccionamiento celular en gradientes de sacarosa.}

Los extractos proteicos fueron obtenidos como se describió previamente para las imnumoprecipitaciones, pero en este caso usando el tampón STE10 (Tris pH 7,5 10 mM, EDTA 10 mM, sacarosa al 10\%,), suplementado con inhibidores de proteasas. Los gradientes fueron hechos en un formador de gradientes en tubos cónicos para ultracentrifugación de $9 / 16$ × 31/2 pulgadas a concentraciones de sacarosa entre 20 y $60 \%$ diluida en un buffer que contenía Tris pH 7,5 10mM y EDTA $10 \mathrm{mM}$. Los extractos fueron cargados sobre el gradiente y centrifugados a $100000 \mathrm{~g}$ durante 16 horas. Se recogieron fracciones de $750 \mu \mathrm{l}$, las cuales fueron tratadas con TCA al 10\% durante 30 minutos en hielo para precipitar las proteínas existentes en cada una de ellas. Los precipitados proteicos fueron lavados dos veces con TCA al 0,2\% y finalmente resuspendidos $50 \mu$ de tampón Laemli al 1X.

\subsection{TÉCNICAS DE MICROSCOPÍA}

\subsubsection{Microscopía óptica.}

Los microorganismos fueron observados en preparación húmeda en un microscopio óptico Nikon Eclipse i90 con una cámara Orca-ER controlada por el programa Metamorph, usando principalmente microscopía de contraste interferencial (DIC).

Tinción con calcoflúor. El calcoflúor es un fluorocromo que en C. albicans tiñe las zonas de la pared celular ricas en quitina. Este se excita al recibir con una longitud de onda de $372 \mathrm{~nm}$ emitiendo fluorescencia azul. El calcoflúor (Blankophor BBH, Bayer Corporation), fue preparado a una concentración de $10 \mathrm{mg} / \mathrm{ml}$ en agua con unas gotas de $\mathrm{KOH} 10 \mathrm{~N}$ para permitir su total disolución. Se esterilizó por filtración y se almacenó a $4^{\circ} \mathrm{C}$ protegido de la luz. Las tinciones con este fluoróforo se realizaron a partir de cultivos creciendo en fase logarítmica, añadiendo $1 \mu l$ de solución de calcoflúor por cada mililitro de muestra a observar al microscopio.

\subsubsection{Microscopía de fluorescencia "in vivo".}

La observación se realizó en un microscopio Personal Deltavision (Applied Precision, LLC) controlado mediante el software SoftWoRx Resolve 3D. Las imágenes fueron capturadas con una cámara CoolSNAP HQ2 (PHOTOMETRICS) ó Orca-ER y procesadas con los programas MetaMorphâ (MDS Analytical Technologies), ImageJ 1.37 (National Institute of Health, USA) y Adobeâ Photoshop CS2 (Adobe System, Inc). Para la observación de cepas que contenían la proteína fluorescente verde (GFP), amarilla (YFP), cian (CFP) o roja (RFP, mCherry), se recogieron cepas en crecimiento exponencial en medio líquido. En función del objetivo del experimento, se tomo una foto del plano central de la célula o bien de a 8 a 12 imágenes de secciones transversales del todo el volumen celular (series en Z) con una separación de 0,3-0,4 $\mu \mathrm{m}$ cada una.

\subsubsection{Microscopía confocal: Recuperación de fluorescencia después de "photobleaching" (FRAP).}

Se utilizó un microscopio confocal Zeiss LSM510 controlado por el programa Zeiss LSM. El quemado de la fluorescencia se realizó con el laser del microscopio a máxima potencia hasta que no se observaba ninguna señal de fluorescencia. Las fotos posteriores fueron tomada cada 40 segundos durante 4-6 minutos. La intensidad de la fluorescencia fue cuantificada con el programa Images y fue normalizada mediante la resta del fondo y la corrección de la fluorescencia perdida por muestras que no habían sido quemadas.

\subsection{RECURSOS BIOINFORMÁTICOS.}

Los programas y recursos bioinformáticos empleados para la realización de este trabajo se encuentran recogidos en la Tabla 5. 
Tabla 2. Estirpes de microorganismos usados utilizados en este trabajo.

\begin{tabular}{|c|c|c|}
\hline Estirpe & Genotipo & Procedencia \\
\hline \multicolumn{3}{|c|}{ C. albicans } \\
\hline BWP17 & $\begin{array}{l}\text { Ura::imm434/ura3::imm434 his1::hisG/ } \\
\text { his1::hisG arg::hisG/arg4::hisG }\end{array}$ & Enloe et al., 2000 \\
\hline OL1036 & BWP17 ACE2-GFP::HIS1/ACE2-GFP::URA3 & Este Trabajo \\
\hline OL1111 & BWP17 ace2A::ARG4/SAT1-pMET3-ACE2 ${ }^{N}$-HA-URA3 & Este Trabajo \\
\hline OL1171 & BWP17 ace2A::ARG4/ACE2 ${ }^{N}$-HIS1, PMET3-ACE2 ${ }^{M} @ R P 10-U R A 3$ & \\
\hline OL1173 & BWP17 ACE2-6HIS::ARG4/ACE2-6HIS::HIS1 & Este Trabajo \\
\hline OL1191 & BWP17 ace $2 \triangle:: A R G 4 / A C E 2^{N}{ }^{-}$HIS1, PMET3-ACE2 ${ }^{\text {MDZn } @ R P 10-U R A 3 ~}$ & Este Trabajo \\
\hline OL1203 & BWP17 ace2A::ARG4/SAT1-pMET3-ACE2 ${ }^{M}$-HA-URA3 & Este Trabajo \\
\hline OL1430 & BWP17 CDC10/CDC10-GFP-ARG4 & González-Novo et al., 2008 \\
\hline OL1444 & BWP17 ace $2 \triangle:: U R A 3 /$ ace2A::HIS1, CDC10-GFP-ARG4 & Este trabajo \\
\hline OL1451 & 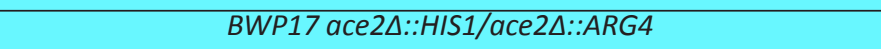 & Este Trabajo \\
\hline OL1456 & BWP17 SEP7/SEP7-GFP-ARG4 & González-Novo et al., 2008 \\
\hline OL1457 & 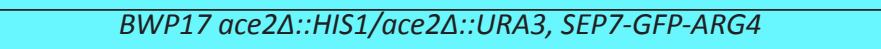 & Este Trabajo \\
\hline OL1483 & BWP17 GIN4/GIN4-GFP-URA3 & \\
\hline OL1484 & BWP17 ace $2 \Delta:: H I S 1 / a c e 2 \Delta:: A R G 4$, GIN4/GIN4-GFP-URA3 & \\
\hline OL1519 & BWP17 CBK1/CBK1-myc-HIS1 & Gutiérrez et al.,2011 \\
\hline OL1538 & BWP17 ace2A::ARG4/ACE2-3HA-URA3 & Este Trabajo \\
\hline OL1551 & BWP17 ace $2 \triangle:: A R G 4 / a c e 2 \triangle Z n-3 H A-U R A 3, C D C 10 / C D C 10-G F P-H I S 1$ & Este Trabajo \\
\hline OL1593 & BWP17 ace $2 \triangle:: A R G 4 / A C E 2^{M}$-GFP-URA3 & Este Trabajo \\
\hline OL1597 & BWP17 ace $2 \triangle:: A R G 4 / A C E 2^{M}-H I S 1$ & Este Trabajo \\
\hline OL1598 & BWP17 ace $2 \triangle:: A R G 4 / A C E 2^{N}-H I S 1$ & Este Trabajo \\
\hline OL1631 & BWP17 ace $2 \triangle:: A R G 4 / A C E 2^{M}{ }^{-H I S 1, ~ S E P 7 / S E P 7-G F P-U R A 3 ~}$ & Este Trabajo \\
\hline OL1634 & BWP17 ace2 $\triangle:: A R G 4 / A C E 2^{N}$-HIS1, SEP7/SEP7-GFP-URA3 & Este Trabajo \\
\hline OL1662 & BWP17 ace2A::ARG4/ACE2 ${ }^{M}-H I S 1, C D C 10 / C D C 10-G F P$ & \\
\hline OL1714 & $\begin{array}{c}\text { BWP17 ace2 } \triangle:: A R G 4 / A C E 2^{N}-H I S 1, \text { PMET3- } \\
\text { ACE2- } \triangle B C D E F @ R P 10-U R A 3\end{array}$ & Este Trabajo \\
\hline OL1716 & 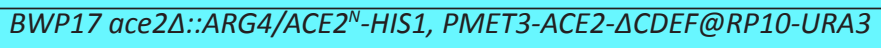 & Este Trabajo \\
\hline OL1719 & BWP17 ACE2-6HIS::ARG4/ACE2-6HIS::HIS1, CBK1/CBK1-myc-URA3 & Este Trabajo \\
\hline OL1722 & BWP17 ace2A::ARG4/SAT1-pMET3-ACE2 ${ }^{N}$-HA-URA3 CBK1/CBK1-myc & Este Trabajo \\
\hline OL1874 & 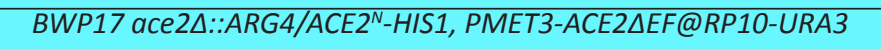 & Este Trabajo \\
\hline OL1876 & BWP17 ace2A::ARG4/ACE2 ${ }^{N}$-HIS1, PMET3-ACE2 $\triangle B @ R P 10-U R A 3$ & Este Trabajo \\
\hline OL1969 & BWP17 GFP-HIS+ & Este Trabajo \\
\hline OL1970 & BWP17 ace2TM-GFP-HIS1 & Este Trabajo \\
\hline OL1976 & BWP17 ace2A::ARG4/SAT1-pMET3-Ace2 ${ }^{M}$-GFP-HIS1 & Este Trabajo \\
\hline OL1978 & BWP17 ace 2D::ARG4/SAT1-pMET3-Ace2 ${ }^{N}$-GFP-HIS1 & Este Trabajo \\
\hline OL1994 & BWP17 ace2A::ARG4/SAT1-pMET3-ACE2 ${ }^{M}$-HA-URA3 CBK1/CBK1-myc & Este Trabajo \\
\hline \multicolumn{3}{|l|}{ E. coli } \\
\hline $\mathrm{DH} 5 \alpha$ & $\begin{array}{l}\text { SupE44DlacU } 199 \text { (F80 lacZ DM15) hsdR17 } \\
\text { recA1 endA1 gyrA96 thi-1 relA1 }\end{array}$ & F. del Rey \\
\hline
\end{tabular}


Tabla 3. Oligonucleótidos utilizados en este trabajo.

\begin{tabular}{|c|c|c|}
\hline Nombre & Secuencia & Propósito \\
\hline 1530 & GACACAACATTGAAGATGGAAGC & Comprobación cepas \\
\hline 1536 & TATACTAGTCATTGGAAATTTCTGAACTTTC & Construcción Ace ${ }^{\mathrm{TM}}-\mathrm{GFP}$ \\
\hline 1537 & TATACTAGTTATAAGACTTGGTTGTGTGCTTCTG & Construcción Ace ${ }^{\mathrm{TM}}-\mathrm{GFP}$ \\
\hline 1538 & $\begin{array}{l}\text { TTGCAACATTAAAAACTCCTCAGTAACACTCTTATCTTCCTGTAGCAACTGTTTTTCTATCCTCT- } \\
\text { CAACCACTGTATCTGTTTTAAGCAATTGTTGTCAAGCACCTGCGCCAGCCCCTGCGC }\end{array}$ & Construcción Ace ${ }^{\top M}$-GFP \\
\hline 1572 & $\begin{array}{l}\text { TTGGCTTCGGAACTTAAAAATAATTGGTCAAAATTTTCATTAGGAAGAGGGATGGTTGA- } \\
\text { cCCTTTGGTCGAGTAATCATCAAACAAGTCAAATTTATTCATGTTTTCTGGGGAGGGTATTTAC }\end{array}$ & Sobreexpresión Ace $2^{\mathrm{M}}$ \\
\hline 1573 & TCAAGTATACGTAATCTCCCC & Comprobación cepas \\
\hline 1582 & TTAAAGCTTCATTTGCAAACAAGTACAAAG & Comprobación cepas \\
\hline 1586 & CTACCACCTTGATGTACACACC & Comprobación cepas \\
\hline 1587 & TATACTAGTTTTATGTTTTTCTTCCTCAAGCTC & Comprobación cepas \\
\hline 1591 & AATTGAAGAAAGCTGGTGCAACCG & Comprobación cepas \\
\hline 1592 & CATTAGGAAGAGGGATGGTTGACCC & Comprobación cepas \\
\hline 1623 & $\begin{array}{l}\text { AGGGCAAACCTCACAACAATCAAACCAAGATTTGAAGAACGCCTCTGGTGTGCCAAATGCTCC- } \\
\text { TATGTTCCAATCAACTACAGGTCA TGCTGCTGCTAGAGGTGCTGGCGCAGGTGCTTC }\end{array}$ & Construcción Cdc10-GFP \\
\hline 1624 & $\begin{array}{l}\text { TTTTGTTCATACGCGTTTTGCTTTTCAACAAACACACAAAAGAAGAGGAATACAAAAAAG- } \\
\text { TAAAATCACATTATATCAATAACAAACATTATTATCTATTCTGATATCATCGATGAATTCGAG }\end{array}$ & Construcción Cdc10-GFP \\
\hline 1625 & TTAAGTAGTGTGTGCACTGCCC & Construcción Ace ${ }^{\mathrm{TM}}$-GFP \\
\hline 1626 & TCGGTCGCTGTTCTCACCAAG & Construcción Ace ${ }^{\mathrm{TM}}$-GFP \\
\hline 1639 & TAAGGATCCATGCATTGGAAATTTCTGAACTTTCGAAAGTACCA & Construcciones @RP10 \\
\hline 1640 & TAACTGCAGCTGGTAATACGCATAATGACTTGTGTATTATACATC & $\begin{array}{l}\text { Construcciones } \\
\text { Ace2 en @RP10 }\end{array}$ \\
\hline 1642 & CCTTCATTCTGTTTATTTGAGACTAC & Comprobación cepas \\
\hline 1643 & CAGGACCGGATGAGGATAAGA & Comprobación cepas \\
\hline 1644 & $\begin{array}{l}\text { TTTAATTAGTATTTGTTGGCTGCTCCACAACACTAACTATCAGAGAATAAATATTAATTAATACT- } \\
\text { GGTAATACGCATAATGACTTGTGTATTATACATCAAATATCTCGAATTCATCGATGATATCAGA }\end{array}$ & Construcción Ace2-6HIS \\
\hline 1645 & $\begin{array}{l}\text { CAACAACAATTGCTTAAAACAGATACAGTGGTTGAGAGGATAGAAAAACAGTTGCTACAGGAAGA- } \\
\text { TAAGAGTGTTACTGAGGAGTTTTTAATGTTGCAACATCACCATCATCACCATCCCGGGTACCCAT }\end{array}$ & Construcción Ace2-6HIS \\
\hline 1691 & $\begin{array}{l}\text { CAATCAATCCTAAAAAGGAAATACCTTTCAAGTATTTTATTTACCATTTTTTCTTTTTTCT- } \\
\text { CATTTACTTTCCCAACTTTTGCACCTCCTTCACTAAATGAAGCTTCGTACGCTGCAGGTC }\end{array}$ & Deleción de ace2 \\
\hline 1692 & $\begin{array}{l}\text { TTGAAAAGGGTAAAATGAAATGAACTGAAATGCAATCTTCTCTCCCACTCGAGCAAA- } \\
\text { CACTCTCTCCATGAAAAACCAACTTGTGGCAGAAGTCTATCTGATATCATCGATGAATTCGAG }\end{array}$ & Deleción de ace2 \\
\hline 1693 & AGAAGGTGGTCATCATGACAGAG & Comprobación cepas \\
\hline 1694 & GCACACACTACTTAATATACACAGC & Comprobación cepas \\
\hline 1727 & $\begin{array}{l}\text { GAGGAAAGAAGAAAAAGAGGAAGGCACGGAAAATAGAATTAAACAACAAGAAATTGTAG- } \\
\text { TTCTTTGTAATTAGTCTTCTACAATAAGATCATTCTGAGGAAGCTTCGTACGCTGCAGGTC }\end{array}$ & Sobreexpresión Ace ${ }^{\mathrm{N}}$ \\
\hline 1728 & $\begin{array}{l}\text { AAGCAGTAAAAGGAAATAAAAAAGAGAGAAAGATCAAATAAATTTAAATGGAAAGAAAGAT- } \\
\text { GGTACTTTCGAAAGTTCAGAAATTTCCAATGCATCATGTTTTCTGGGGAGGGTATTTAC }\end{array}$ & Sobreexpresión Ace $2^{\mathrm{N}}$ \\
\hline 1734 & TATGGATCCGGAACTAGTCCCGGGTACCCATACGATGTT & $\begin{array}{l}\text { Construcción de trunca- } \\
\text { ciones de Ace2 en } R P 10\end{array}$ \\
\hline 1735 & ATATCGCAGCTAAGCGTAATCTGGAACGTC & $\begin{array}{l}\text { Construcción de trunca- } \\
\text { ciones de Ace2 en RP10 }\end{array}$ \\
\hline 1775 & & RACE \\
\hline 1781 & TAACTCGAGGTTCCGAAGCCAATGATATGG & $\begin{array}{l}\text { Construcción de trunca- } \\
\text { ciones de Ace2 en } R P 10\end{array}$ \\
\hline 1782 & TTTAAGCTTTTTATGTTTTTCTTCTCAAGCTC & $\begin{array}{l}\text { Construcción de trunca- } \\
\text { ciones de Ace2 en RP10 }\end{array}$ \\
\hline 1787 & ATAATCGATGACAACCAAATGGACGATCAC & $\begin{array}{l}\text { Construcción de trunca- } \\
\text { ciones de Ace2 en RP10 }\end{array}$ \\
\hline 1788 & TTTAAGATTTTGCAACATTAAAAACTCCTCAGTAA & Construcción Ace $2 \Delta \mathrm{Zn}$ \\
\hline 1789 & TTTAAGCTTTGTCCAGTAATTGTCCAATTCAC & Construcción Ace $2 \Delta Z n$ \\
\hline 1812 & $\begin{array}{l}\text { AAAGCAGTAAAAGGAAATAAAAAAGAGAGAAAGATCAAATAAATTTAAATGGAAAGA- } \\
\text { AAGATGGTACTTTCGAAACTTCAGAAATTTCCAATGTCATATTTAGTGAAGG }\end{array}$ & Construcción $\mathrm{Ace}^{\mathrm{M}}$ \\
\hline
\end{tabular}




\begin{tabular}{|c|c|c|}
\hline 1813 & $\begin{array}{l}\text { GCTTCGGAACTTAAAAATAATTGGTCAAAATTTTCATTAGGAAGAGGGATGGTTGA- } \\
\text { CCCTTTGGTCGAGTAATCATCAAACAAGTCAAATTTATTCAATATAAGACTT }\end{array}$ & Construcción Ace $^{\mathrm{N}}$ \\
\hline 1818 & $\begin{array}{l}\text { TCTTTTGTCTCTTTTTTATTTCCTTTTACTGCTTTCCCATCCTATATATTTGTTTCTTCTTTAAT- } \\
\text { CAAGTCCATTCATTCAGAAGCACACAACCAAGTCTTATAGGTGCTGGCGCAGGTGCTTC }\end{array}$ & Construcción Ace2 ${ }^{\mathrm{M}}$-GFP \\
\hline 1831 & CAAGTATACGTAATCTCCCC & Comprobación cepas \\
\hline 1832 & $\begin{array}{l}\text { AAAGCAGTAAAAGGAAATAAAAAAGAGAGAAAGATCAAATAAATTTAAATGGAAAGA- } \\
\text { AAGATGGTACTTTCGAAAGTTCAGAAATTTCCAATGAAAATTTAGTGAAGG }\end{array}$ & Construcción Ace ${ }^{\mathrm{M}}$ \\
\hline 1838 & GAGAGTAACCACTCCTAGT & Comprobación cepas \\
\hline 1840 & CAGCAAATTGAATATGTGGAT & Comprobación cepas \\
\hline 1859 & GTGTTACGAATCAATGGCACTACAGC & Comprobación cepas \\
\hline 1861 & TGGACAATTACTGGACAGGAC & Comprobación cepas \\
\hline 1863 & CATGCCGTTTCATATGATCTG & Comprobación cepas \\
\hline 1916 & $\begin{array}{l}\text { GTTATATAATATACATAAGAAATAAAACAAGCCAAATTAGTATACTGAAAAAAAAAATTCA- } \\
\text { TAAATAATGCATCATTGTTCTCAAATTTGATTATCCTCTTCTGATATCATCGATGAATTCGAG }\end{array}$ & Construcción Gin4-GFP \\
\hline 1917 & $\begin{array}{l}\text { AGAAATTGTTTGTGTTAGAGTGAAAGGATCTAAAGTTACAACTGATACTTTATTTTCTGA- } \\
\text { AATTGAAAAGGTCTTACTCAAAGAAGGTGTTTTAGATAAAGGTGCTGGCGCAGGTGCTTC }\end{array}$ & Construcción Gin4-GFP \\
\hline 1931 & CGAAGCTTTTGCAACATTAAAAACTCCTC & Construcción Ace2-HA \\
\hline 1932 & CGAAGCTTTGTTGCCAATGAAATCCC & Construcción Ace2-HA \\
\hline 1955 & $\begin{array}{l}\text { TTCAGAATATCATCARGATGATAGTACACCAAATTATGAAACTTCAAGATTGCAAAAGGAT- } \\
\text { GAAACTTTGACTGATTTACATTCGATTGTAAGCAATCATGGTGCTGGCGCAGGTGCTTC }\end{array}$ & Construcción Sep7-GFP \\
\hline 1956 & $\begin{array}{l}\text { ACATTTTATTGAAATTATAAATTTTAATAAAACGTTTCAACTTC- } \\
\text { TATATAGAATTCTCTCTCTTTTCTCTTTCTCTCTGTGTGTAAATT- } \\
\text { GCTCATCTTCCTCTGATATCATCGATGAATTCGAG }\end{array}$ & Construcción Sep7-GFP \\
\hline 1961 & GCACACACTACTTAATATACACAGC & Comprobación cepas \\
\hline 1965 & TTAACCGGCATAGCTTGG & Comprobación cepas \\
\hline 1972 & AAAGTTTAAACCAATTACTGTAAATGCCTGCACTC & Construcciones Ace2 \\
\hline 1975 & TTTACTAGTATATCGATTATAAGACTTGGTTGTGTGCTTC & Construcciones Ace2 \\
\hline 1976 & TCTAGCTTCAATGTGCCCTTTCACAGTATATATCTTATCCTCATCCGG & $\begin{array}{l}\text { Construcciones de trunca- } \\
\text { ciones de Ace } 2 \text { en } R P 10\end{array}$ \\
\hline 1977 & CCGGATGAGGATAAGATATATACTGTGAAAGGGCACATTGAAGCTAGA & $\begin{array}{l}\text { Construcciones de trunca- } \\
\text { ciones de Ace2 en RP10 }\end{array}$ \\
\hline 1980 & CTAAATATGCATTGGAAATTTCTG & qRT-PCR y RT-PCR \\
\hline 1982 & CCAAGTCTTATAATGAATAAATTTGAC & qRT-PCR y RT-PCR \\
\hline 1983 & TTCCACTGTATTGTCTACTGTG & qRT-PCR y RT-PCR \\
\hline 1987 & $\begin{array}{l}\text { TCAACAACAATTGCTTAAAACAGATACAGTGGTTGAGAGATAGAAAAACAGTTGCTACAG- } \\
\text { GAAGATAAGAGTGTTACTGAGGAGTTTTTAATGTTGCAAGGTGCTGGCGCAGGTGCTTC }\end{array}$ & Construcciones Ace2-GFP \\
\hline 1988 & $\begin{array}{l}\text { GTATAATTTTGAAAAGGGTAAAATGAAATGAACTGAAATGCAATCTTCTCTCCCACTCGAGCA- } \\
\text { AACACTCTCTCCATGAAAAACCAACTTGTGGCAGAAGTTCTGATATCATCGATGAATTCGAG }\end{array}$ & Construcciones Ace2-GFP \\
\hline 1989 & ATTCCCACCAATGGAGATTC & qRT-PCR y RT-PCR \\
\hline 1990 & TGTTGTCACATCTTCCATGC & qRT-PCR y RT-PCR \\
\hline 1993 & GGTTCTCAAACACCAACACC & qRT-PCR y RT-PCR \\
\hline 1994 & TCAAGCTCATCCTCCTCAAG & qRT-PCR y RT-PCR \\
\hline 1995 & TCTGAACTTTCGAAAGTACC & qRT-PCR y RT-PCR \\
\hline 1996 & GATGGGAAAGCAGTAAAAGG & qRT-PCR y RT-PCR \\
\hline 1997 & САССТССТTCACTAAATATGC & qRT-PCR y RT-PCR \\
\hline 2047 & TTAGGAAGAGGGATGGTTGAC & RACE \\
\hline 2065 & GTGGCGCGAATTCACTAGTGATTG & Comprobación cepas \\
\hline 2067 & GGCCAGTGTTCCTGATAATCCAGC & Comprobación cepas \\
\hline 2069 & GCGCAACAGATATATTGGTGC & Comprobación cepas \\
\hline 207 & & Construcciones Cbk1-myk \\
\hline 2071 & & Construcciones Cbk1-myk \\
\hline
\end{tabular}


Tabla 4. Anticuerpos utilizados en este trabajo.

\begin{tabular}{|c|c|c|}
\hline Nombre & Procedencia & Casa Comercial \\
\hline Anti-Tubulina & Conejo & Sigma \\
\hline Anti-Cdc11 (y-415) & Conejo & Santa Cruz Biotechnology \\
\hline Anti-GFP (JL-8) & Ratón & Living Colors \\
\hline Anti-cMyc (9E-10) & Ratón & Santa Cruz Biotechnology \\
\hline Anti-HIS probe & Conejo & Santa Cruz Biotechnology \\
\hline Anti-HA high Affinity & Rata & Roche \\
\hline Anti-Cdc2p34 (PSTAIRE) & Conejo & Santa Cruz Biotechnology \\
\hline Anti-FTCD (58K-9) (Anti-Golgi) & Ratón & Sigma \\
\hline Anti-Pol II 8WG16 (anti-Núcleo) & Ratón & Santa Cruz Biotechnology \\
\hline Anti-Pma1 (anti-membrana) & Conejo & Cortesía \\
\hline Anti-Conejo ECL & Ratón & Santa Cruz Biotechnology \\
\hline Anti-Rata ECL & Cabra & Santa Cruz Biotechnology \\
\hline Anti-Ratón ECL & Oveja & Amersham \\
\hline
\end{tabular}

Tabla 5. Recursos bioinformáticos utilizados durante este trabajo.

\begin{tabular}{|c|c|}
\hline Programa & Dirección electrónica \\
\hline Adobe ${ }^{\circledR}$ Illustrator CS5 & http://www.adobe.com/ \\
\hline Adobe ${ }^{\circledR}$ InDesing CS5 & http://www.adobe.com/ \\
\hline Adobe ${ }^{\circledR}$ Photoshop CS5 & http://www.adobe.com/ \\
\hline EndNote $^{\circledR}$ IX & http://www.endnote.com/ \\
\hline DNASTAR & http://www.dnastar.com/ \\
\hline Base de datos de C. albicans & http://www.candidagenome.org/ \\
\hline Base de datos de $S$. cerevisiae & http://www.yeastgenome.org/ \\
\hline GeneDB & http://www.genedb.org/ \\
\hline BLAST & http://blast.ncbi.nlm.nih.gov/ \\
\hline SMART & http://smart.embl-heidelberg.de/ \\
\hline Image J & http://rsbweb.nih.gov/ij/ \\
\hline ClustalW & http://www.ebi.ac.uk/Tools/msa/clustalw2/ \\
\hline Pfam & http://pfam.sanger.ac.uk/ \\
\hline Interpro & http://www.ebi.ac.uk/interpro/ \\
\hline MetaMorph ${ }^{\circledR}$ & www.moleculardevices.com/ \\
\hline
\end{tabular}





\section{Bibliografía}



Alonso-Núñez, M. L., An, H., Martín-Cuadrado, A. B., Mehta, S., Petit, C., Sipiczki, M., Rey, F. del, Gould, K. L. y Vázquez de Aldana, C. R. (2005). Ace2p controls the expression of genes required for cell separation in Schizosaccharomyces pombe. Mol. Biol. Cell 16, 2003-2017.

Altman, R. y Kellogg, D. (1997). Control of mitotic events by Nap1 and the Gin4 kinase. J. Cell Biol. 138, 119-130.

Archambault, V., Chang, E. J., Drapkin, B. J., Cross, F. R., Chait, B. T. y Rout, M. P. (2004). Targeted proteomic study of the cyclin-Cdk module. Mol. Cell 14, 699-711.

Arkowitz, R. A. (2011). Polarized growth and movement: how to generate new shapes and structures. Semin. Cell Dev. Biol. 22, 789.

Arkowitz, R. A. y Bassilana, M. (2011). Polarized growth in fungi: Symmetry breaking and hyphal formation. Semin. Cell Dev. Biol. 8, 806-815.

Asano, S., Park, J.-E., Yu, L.-R., Zhou, M., Sakchaisri, K., Park, C. J., Kang, Y. H., Thorner, J., Veenstra, T. D. y Lee, K. S. (2006). Direct phosphorylation and activation of a Nim1-related kinase Gin4 by Elm1 in budding yeast. J. Biol. Chem. 281, 27090-27098.

Asleson, C. M., Bensen, E. S., Gale, C. A., Melms, A. S., Kurischko, C. y Berman, J. (2001). Candida albicans INT1-induced filamentation in Saccharomyces cerevisiae depends on Sla2p. Mol. Cell. Biol. 21, 1272-1284.

Bachewich, C. y Whiteway, M. (2005). Cyclin Cln3p links G1 progression to hyphal and pseudohyphal development in Candida albicans. Eukaryot. Cell 4, 95-102.

Baladrón, V., Ufano, S., Dueñas, E., Martín-Cuadrado, A. B., Rey, F. del y Vázquez de Aldana, C. R. (2002). Eng1p, an endo$1,3-\beta$-glucanase localized at the daughter side of the septum, is involved in cell separation in Saccharomyces cerevisiae. Eukaryot. Cell 1, 774-786.

Banerjee, M., Thompson, D. S., Lazzell, A., Carlisle, P. L., Pierce, C., Monteagudo, C., López-Ribot, J. L. y Kadosh, D. (2008). UME6, a novel filament-specific regulator of Candida albicans hyphal extension and virulence. Mol. Biol. Cell 19, 13541365.

Barral, Y. y Kinoshita, M. (2008). Structural insights shed light onto septin assemblies and function. Curr. Opin. Cell Biol. 20, 12-18.

Barral, Y., Mermall, V., Mooseker, M. S. y Snyder, M. (2000). Compartmentalization of the cell cortex by septins is required for maintenance of cell polarity in yeast. Mol. Cell 5, 841-851.

Barral, Y., Parra, M., Bidlingmaier, S. y Snyder, M. (1999). Nim1-related kinases coordinate cell cycle progression with the organization of the peripheral cytoskeleton in yeast. Genes Dev. 13, 176-187.

Bartnicki-Garcia, S. (2002). Hyphal tip growth: outstanding questions. Molecular biology of fungal development, p. 29-58. Marcel Dekker, New York, NY.

Bassilana, M., Blyth, J. y Arkowitz, R. A. (2003). Cdc24, the GDP-GTP exchange factor for Cdc42, is required for invasive hyphal growth of Candida albicans. Eukaryot. Cell 2, 9-18.

Bassilana, M., Hopkins, J. y Arkowitz, R. A. (2005). Regulation of the Cdc42/Cdc24 GTPase module during Candida albicans hyphal growth. Eukaryot. Cell . 4, 588-603.

Beltrao, P., Trinidad, J. C., Fiedler, D., Roguev, A., Lim, W. A., Shokat, K. M., Burlingame, A. L. y Krogan, N. J. (2009). Evolution of phosphoregulation: comparison of phosphorylation patterns across yeast species. PLoS Biol. 7, e1000134.

Bensen, E. S., Clemente-Blanco, A., Finley, K. R., Correa-Bordes, J. y Berman, J. (2005). The mitotic cyclins Clb2p and Clb4p affect morphogenesis in Candida albicans. Mol. Biol. Cell 16, 3387-3400.

Bensen, E. S., Filler, S. G. y Berman, J. (2002). A forkhead transcription factor is important for true hyphal as well as yeast morphogenesis in Candida albicans. Eukaryot. Cell 1, 787-798.

Berlin, A., Paoletti, A. y Chang, F. (2003). Mid2p stabilizes septin rings during cytokinesis in fission yeast. J. Cell Biol. 160, 1083-1092.

Berman, J. (2006). Morphogenesis and cell cycle progression in Candida albicans. Curr. Opin. Microbiol. 9, 595-601.

Berman, J. y Sudbery, P. E. (2002). Candida albicans: a molecular revolution built on lessons from budding yeast. Nat. Rev. Genet. 3, 918-930.

Bertin, A., McMurray, M. A., Grob, P., Park, S.-S., Garcia, G., Patanwala, I., Ng, H.-L., Alber, T., Thorner, J. y Nogales, E. (2008). Saccharomyces cerevisiae septins: supramolecular organization of heterooligomers and the mechanism of filament assembly. Proc. Natl. Acad. Sci. U.S.A. 105, 8274-8279.

Bertin, A., McMurray, M. A., Pierson, J., Thai, L., McDonald, K. L., Zehr, E. A., Garcia, G., Peters, P., Thorner, J. y Nogales, E. 
(2012). Three-dimensional ultrastructure of the septin filament network in Saccharomyces cerevisiae. Mol. Biol. Cell 23, 423-432.

Bertin, A., McMurray, M. A., Thai, L., Garcia, G., Votin, V., Grob, P., Allyn, T., Thorner, J. y Nogales, E. (2010). Phosphatidylinositol-4,5-bisphosphate promotes budding yeast septin filament assembly and organization. J. Mol. Biol. 404, 711-731.

Bharucha, N., Chabrier-Rosello, Y., Xu, T., Johnson, C., Sobczynski, S., Song, Q., Dobry, C. J., Eckwahl, M. J., Anderson, C. P., Benjamin, A. J. y Krysan, D. (2011). A large-scale complex haploinsufficiency-based genetic interaction screen in Candida albicans: analysis of the RAM network during morphogenesis. PLoS Genet. 7, e1002058.

Bichsel, S. J., Tamaskovic, R., Stegert, M. R. y Hemmings, B. A. (2004). Mechanism of activation of NDR (nuclear Dbf2related) protein kinase by the hMOB1 protein. J. Biol. Chem. 279, 35228-35235.

Bidlingmaier, S., Weiss, E. L., Seidel, C., Drubin, D. G. y Snyder, M. (2001). The Cbk1p pathway is important for polarized cell growth and cell separation in Saccharomyces cerevisiae. Mol. Cell. Biol. 21, 2449-2462.

Biondi, R. M., Komander, D., Thomas, C. C., Lizcano, J. M., Deak, M., Alessi, D. R. y Van Aalten, D. M. F. (2002). High resolution crystal structure of the human PDK1 catalytic domain defines the regulatory phosphopeptide docking site. EMBO J. 21, 4219-4228.

Bishop, A., Lane, R., Beniston, R. y Chapa-y-Lazo, B. (2010). Hyphal growth in Candida albicans requires the phosphorylation of Sec2 by the Cdc28-Ccn1/Hgc1 kinase. EMBO J. 29, 2930-2942.

Biswas, S., Van Dijck, P. y Datta, A. (2007). Environmental sensing and signal transduction pathways regulating morphopathogenic determinants of Candida albicans. Microbiol. Mol. Biol. Rev. 71, 348-376.

Borth, N., Walther, A., Reijnst, P., Jorde, S., Schaub, Y. y Wendland, J. (2010). Candida albicans Vrp1 is required for polarized morphogenesis and interacts with Wal1 and Myo5. Microbiology 156, 2962-2969.

Botstein, D. y Fink, G. R. (2011). Yeast: an experimental organism for 21st Century biology. Genetics 189, 695-704.

Bouquin, N., Barral, Y., Courbeyrette, R., Blondel, M., Snyder, M. y Mann, C. (2000). Regulation of cytokinesis by the Elm1 protein kinase in Saccharomyces cerevisiae. J. Cell. Sci. 113, 1435-1445.

Bourens, M., Panozzo, C., Nowacka, A. y Imbeaud, S. (2009). Mutations in the Saccharomyces cerevisiae kinase Cbk1p lead to a fertility defect that can be suppressed by the absence of Brr1p or Mpt5p (Puf5p), proteins involved in RNA metabolism. Genetics. 183, 161-163.

Brace, J., Hsu, J. y Weiss, E. L. (2011). Mitotic exit control of the Saccharomyces cerevisiae Ndr/LATS kinase Cbk1 regulates daughter cell separation after cytokinesis. Mol. Cell. Biol. 31, 2762-2777

Braun, B. R. y Johnson, A. D. (1997). Control of filament formation in Candida albicans by the transcriptional repressor TUP1. Science 277, 105-109.

Braun, B. R. y Johnson, A. D. (2000). TUP1, CPH1 and EFG1 make independent contributions to filamentation in Candida albicans. Genetics. 155, 57-67.

Braun, B. R., Kadosh, D. y Johnson, A. D. (2001). NRG1, a repressor of filamentous growth in C. albicans, is down-regulated during filament induction. EMBO J. 20, 4753-4761.

Byers, B. y Goetsch, L. (1976). A highly ordered ring of membrane-associated filaments in budding yeast. J. Cell Biol. 69, 717-721.

Caballero-Lima (2009). Mecanismos moleculares que regulas la asimetría y Citocinesis durante el desarrollo hifal. Tesis Doctoral . Universidad de Extremadura.

Cantero, P. D. y Ernst, J. F. (2011). Damage to the glycoshield activates PMT-directed O-mannosylation via the Msb2-Cek1 pathway in Candida albicans. Mol. Microbiol. 80, 715-725.

Cao, L., Ding, X., Yu, W., Yang, X., Shen, S. y Yu, L. (2007). Phylogenetic and evolutionary analysis of the septin protein family in metazoan. FEBS Lett. 581, 5526-5532.

Care, R. S., Trevethick, J., Binley, K. M. y Sudbery, P. E. (1999). The MET3 promoter: a new tool for Candida albicans molecular genetics. Mol. Microbiol. 34, 792-798.

Carlisle, P. L. y Kadosh, D. (2010). Candida albicans Ume6, a filament-specific transcriptional regulator, directs hyphal growth via a pathway involving Hgc1 cyclin-related protein. Eukaryot. Cell 9, 1320-1328.

Carlisle, P. L., Banerjee, M., Lazzell, A., Monteagudo, C., López-Ribot, J. L. y Kadosh, D. (2009). Expression levels of a filamentspecific transcriptional regulator are sufficient to determine Candida albicans morphology and virulence. Proc. Natl. Acad. Sci. U.S.A. 106, 599-604. 
Carlson, M. y Botstein, D. (1982). Two differentially regulated mRNAs with different 5' ends encode secreted with intracellular forms of yeast invertase. Cell 28, 145-154.

Casamayor, A. y Snyder, M. (2003). Molecular dissection of a yeast septin: distinct domains are required for septin interaction, localization, and function. Mol. Cell. Biol. 23, 2762-2777.

Caudron, F. y Barral, Y. (2009). Septins and the lateral compartmentalization of eukaryotic membranes. Dev. Cell 16, $493-506$.

Caviston, J. P., Longtine, M., Pringle, J. R. y Bi, E. (2003). The role of Cdc42p GTPase-activating proteins in assembly of the septin ring in yeast. Mol. Biol. Cell 14, 4051-4066.

Chapa y Lazo, B., Bates, S. y Sudbery, P. (2005). The G1 cyclin Cln3 regulates morphogenesis in Candida albicans. Eukaryot. Cell 4, 90-94.

Chatr-Aryamontri, A., Breitkreutz, B.-J., Heinicke, S., Boucher, L., Winter, A., Stark, C., Nixon, J., Ramage, L., Kolas, N., O'Donnell, L. y Tyers, M. (2013). The BioGRID interaction database: 2013 update. Nucleic Acids Res. 41, D816-23.

Chen, H., Fujita, M., Feng, Q., Clardy, J. y Fink, G. R. (2004). Tyrosol is a quorum-sensing molecule in Candida albicans. Proc. Natl. Acad. Sci. U.S.A. 101, 5048-5052.

Chen, Y. N., Slabaugh, E. y Brandizzi, F. (2008). Membrane-tethered transcription factors in Arabidopsis thaliana: novel regulators in stress response and development. Curr. Opin. Plant Biol. 11, 695-711.

Chibana, H., Beckerman, J. L. y Magee, P. T. (2000). Fine-resolution physical mapping of genomic diversity in Candida albicans. Genome Res. 10, 1865-1877.

Cid, V. J., Adamiková, L., Sánchez, M., Molina, M. y Nombela, C. (2001). Cell cycle control of septin ring dynamics in the budding yeast. Microbiology 147, 1437-1450.

Clemente-Blanco, A., González-Novo, A., Machín, F., Caballero-Lima, D., Aragón, L., Sánchez, M., Vázquez de Aldana, C. R., Jiménez, J. y Correa-Bordes, J. (2006). The Cdc14p phosphatase affects late cell-cycle events and morphogenesis in Candida albicans. J. Cell. Sci. 119, 1130-1143.

Colman-Lerner, A., Chin, T. E. y Brent, R. (2001). Yeast Cbk1 and Mob2 activate daughter-specific genetic programs to induce asymmetric cell fates. Cell 107, 739-750.

Cong, J., Geng, W., He, B., Liu, J., Charlton, J. y Adler, P. N. (2001). The furry gene of Drosophila is important for maintaining the integrity of cellular extensions during morphogenesis. Development 128, 2793-2802.

Cornils, H., Kohler, R. S., Hergovich, A. y Hemmings, B. A. (2011). Human NDR kinases control G(1)/S cell cycle transition by directly regulating p21 stability. Mol. Cell. Biol. 31, 1382-1395.

Costanzo, M., Baryshnikova, A., Bellay, J. y Kim, Y. (2010). The genetic landscape of a cell. Science. 327, $425-431$.

Court, H. y Sudbery, P. (2007). Regulation of Cdc42 GTPase activity in the formation of hyphae in Candida albicans. Mol. Biol. Cell 18, 265-281.

Crampin, H., Finley, K., Gerami-Nejad, M., Court, H., Gale, C., Berman, J. y Sudbery, P. (2005). Candida albicans hyphae have a Spitzenkörper that is distinct from the polarisome found in yeast and pseudohyphae. J. Cell. Sci. 118, $2935-2947$.

De Luca, C., Guglielminetti, M., Ferrario, A., Calabr, M. y Casari, E. (2012). Candidemia: species involved, virulence factors and antimycotic susceptibility. New Microbiol. 35, 459-468.

De Virgilio, C., DeMarini, D. J. y Pringle, J. R. (1996). SPR28, a sixth member of the septin gene family in Saccharomyces cerevisiae that is expressed specifically in sporulating cells. Microbiology 142, 2897-2905.

DeMay, B. S., Meseroll, R. A., Occhipinti, P. y Gladfelter, A. S. (2009). Regulation of distinct septin rings in a single cell by Elm1p and Gin4p kinases. Mol. Biol. Cell 20, 2311-2326.

DeMay, B. S., Meseroll, R. A., Occhipinti, P. y Gladfelter, A. S. (2010). Cellular requirements for the small molecule forchlorfenuron to stabilize the septin cytoskeleton. Cytoskeleton 67, 383-399.

Di Talia, S., Wang, H., Skotheim, J. M., Rosebrock, A. P., Futcher, B. y Cross, F. R. (2009). Daughter-specific transcription factors regulate cell size control in budding yeast. PLoS Biol. 7, e1000221.

Dobbelaere, J. y Barral, Y. (2004). Spatial coordination of cytokinetic events by compartmentalization of the cell cortex. Science 305, 393-396.

Dobbelaere, J., Gentry, M. S., Hallberg, R. L. y Barral, Y. (2003). Phosphorylation-dependent regulation of septin dynamics during the cell cycle. Dev. Cell 4, 345-357.

Dohrmann, P. R., Butler, G., Tamai, K., Dorland, S., Greene, J. R., Thiele, D. J. y Stillman, D. J. (1992). Parallel pathways of gene regulation: homologous regulators SWI5 and ACE2 differentially control transcription of $\mathrm{HO}$ and chitinase. Genes Dev. 6, 93-104. 
Dohrmann, P. R., Voth, W. P. y Stillman, D. J. (1996). Role of negative regulation in promoter specificity of the homologous transcriptional activators Ace2p and Swi5p. Mol. Cell. Biol. 16, 1746-1758.

Du, L.-L. y Novick, P. (2002). Pag1p, a novel protein associated with protein kinase Cbk1p, is required for cell morphogenesis and proliferation in Saccharomyces cerevisiae. Mol. Biol. Cell 13, 503-514.

Dünkler, A., Walther, A., Specht, C. A. y Wendland, J. (2005). Candida albicans CHT3 encodes the functional homolog of the Cts1 chitinase of Saccharomyces cerevisiae. Fungal Genet. Biol. 42, 935-947.

Edgar, B. A. (2006). From cell structure to transcription: Hippo forges a new path. Cell 124, 267-273.

Egelhofer, T. A., Villén, J., McCusker, D., Gygi, S. P. y Kellogg, D. R. (2008). The septins function in G1 pathways that influence the pattern of cell growth in budding yeast. PLOS ONE 3, e2022.

Ejzykowicz, D. E., Cunha, M. M., Rozental, S., Solis, N. V., Gravelat, F. N., Sheppard, D. C. y Filler, S. G. (2009). The Aspergillus fumigatus transcription factor Ace2 governs pigment production, conidiation and virulence. Mol. Microbiol. 72, 155-169.

Eluère, R., Varlet, I., Bernadac, A. y Simon, M.-N. (2012). Cdk and the anillin homolog Bud4 define a new pathway regulating septin organization in yeast. Cell Cycle 11, 151-158.

Emoto, K. (2011). Dendrite remodeling in development and disease. Dev. Growth Differ. 53, 277-286.

Enserink, J. M., Smolka, M. B., Zhou, H. y Kolodner, R. D. (2006). Checkpoint proteins control morphogenetic events during DNA replication stress in Saccharomyces cerevisiae. J. Cell Biol. 175, 729-741.

Epp, E., Walther, A., Lépine, G. y Leon, Z. (2010). Forward genetics in Candida albicans that reveals the Arp2/3 complex is required for hyphal formation, but not endocytosis. Mol. Microbiol. 75, 1182-1198

Esteban, P. F., Ríos, I., García, R., Dueñas, E., Plá, J., Sánchez, M., Vázquez de Aldana, C. R. y Rey, F. del (2005). Characterization of the CaENG1 gene encoding an endo-1,3- $\beta$-glucanase involved in cell separation in Candida albicans. Curr. Microbiol. 51, 385-392.

Estey, M. P., Kim, M. S. y Trimble, W. S. (2011). Septins. Curr. Biol. 21, R384-7.

Evangelista, C. C., Rodriguez Torres, A. M., Limbach, M. P. y Zitomer, R. S. (1996). Rox3 and Rts1 function in the global stress response pathway in baker's yeast. Genetics 142, 1083-1093.

Fang, H.-M. y Wang, Y. (2006). RA domain-mediated interaction of Cdc35 with Ras1 is essential for increasing cellular cAMP level for Candida albicans hyphal development. Mol. Microbiol. 61, 484-496.

Fares, H., Goetsch, L. y Pringle, J. R. (1996). Identification of a developmentally regulated septin and involvement of the septins in spore formation in Saccharomyces cerevisiae. J. Cell Biol. 132, 399-411.

Faty, M., Fink, M. y Barral, Y. (2002). Septins: a ring to part mother and daughter. Curr. Genet. 41, 123-131.

Feng, Q., Summers, E., Guo, B. y Fink, G. (1999). Ras signaling is required for serum-induced hyphal differentiation in Candida albicans. J. Bacteriol. 181, 6339-6346.

Fütterer, J., Kiss-László, Z. y Hohn, T. (1993). Nonlinear ribosome migration on cauliflower mosaic virus 35S RNA. Cell 73:789802.

Finkel, J. S., Xu, W., Huang, D., Hill, E. M., Desai, J. V., Woolford, C. A., Nett, J. E., Taff, H., Norice, C. T., Andes, D. R. y Mitchell, A. (2012). Portrait of Candida albicans adherence regulators. PLoS Pathog. 8, e1002525.

Gale, C. A., Bendel, C. M., McClellan, M., Hauser, M., Becker, J. M., Berman, J. y Hostetter, M. K. (1998). Linkage of adhesion, filamentous growth, and virulence in Candida albicans to a single gene, INT1. Science 279, 1355-1358.

Gale, C., Gerami-Nejad, M. y McClellan, M. (2001). Candida albicans Int1p interacts with the septin ring in yeast and hyphal cells. Mol. Biol. Cell 12, 3538-3549.

Ganguly, S. y Mitchell, A. P. (2011). Mucosal biofilms of Candida albicans. Curr. Opin. Microbiol. 14, 380-385.

Garcia, G., Bertin, A., Li, Z., Song, Y., McMurray, M. A., Thorner, J. y Nogales, E. (2011). Subunit-dependent modulation of septin assembly: budding yeast septin Shs1 promotes ring and gauze formation. J. Cell Biol. 195, 993-1004.

Gilden, J. y Krummel, M. F. (2010). Control of cortical rigidity by the cytoskeleton: emerging roles for septins. Cytoskeleton 67, 477-486.

Giri, S. y Kindo, A. J. (2012). A review of Candida species causing blood stream infection. Indian J. Med. Microbiol. 30, 270-278.

Gladfelter, A. S. (2010). Guides to the final frontier of the cytoskeleton: septins in filamentous fungi. Curr. Opin. Microbiol. 13, 720-726.

Gladfelter, A. S., Bose, I., Zyla, T. R., Bardes, E. S. G. y Lew, D. J. (2002). Septin ring assembly involves cycles of GTP loading and hydrolysis by Cdc42p. J. Cell Biol. 156, 315-326. 
Gladfelter, A. S., Kozubowski, L., Zyla, T. R. y Lew, D. J. (2005). Interplay between septin organization, cell cycle and cell shape in yeast. J. Cell. Sci. 118, 1617-1628.

Gladfelter, A. S., Pringle, J. R. y Lew, D. J. (2001). The septin cortex at the yeast mother-bud neck. Curr. Opin. Microbiol. 4, 681-689.

Gladfelter, A. S., Zyla, T. R. y Lew, D. J. (2004). Genetic interactions among regulators of septin organization. Eukaryot. Cell 3, 847-854.

Gola, S., Martin, R., Walther, A., Dünkler, A. y Wendland, J. (2003). New modules for PCR-based gene targeting in Candida albicans: rapid and efficient gene targeting using 100 bp of flanking homology region. Yeast 20, 1339-1347.

González-Novo, A., Correa-Bordes, J., Labrador, L., Sánchez, M., Vázquez de Aldana, C. R. y Jiménez, J. (2008). Sep7 is essential to modify septin ring dynamics and inhibit cell separation during Candida albicans hyphal growth. Mol. Biol. Cell 19, 1509-1518.

González-Novo, A., Labrador, L., Jiménez, A., Sánchez-Pérez, M. y Jiménez, J. (2006). Role of the septin Cdc10 in the virulence of Candida albicans. Microbiol. Immunol. 50, 499-511.

González-Novo, A., Vázquez de Aldana, C. R. y Jiménez, J. (2009). Fungal septins: one ring to rule it all? Cent. Eur. J. Biol. 4, 274-289.

Goodwin, T. J. y Poulter, R. T. (2000). Multiple LTR-retrotransposon families in the asexual yeast Candida albicans. Genome Res. 10, 174-191.

Grava, S., Schaerer, F., Faty, M., Philippsen, P. y Barral, Y. (2006). Asymmetric recruitment of dynein to spindle poles and microtubules promotes proper spindle orientation in yeast. Dev. Cell 10, 425-439.

Gutiérrez-Escribano, P., González-Novo, A., Suárez, M. B., Li, C.-R., Wang, Y., Vázquez de Aldana, C. R. y Correa-Bordes, J. (2011). CDK-dependent phosphorylation of Mob2 is essential for hyphal development in Candida albicans. Mol. Biol. Cell 22, 2458-2469.

Gutiérrez-Escribano, P., Zeidler, U., Suárez, M. B., Bachellier-Bassi, S., Clemente-Blanco, A., Bonhomme, J., Vázquez de Aldana, C. R., d'Enfert, C. y Correa-Bordes, J. (2012). The NDR/LATS Kinase Cbk1 Controls the Activity of the Transcriptional Regulator Bcr1 during Biofilm Formation in Candida albicans. PLoS Pathog. 8, e1002683.

Haarer, B. K. y Pringle, J. R. (1987). Immunofluorescence localization of the Saccharomyces cerevisiae CDC12 gene product to the vicinity of the 10-nm filaments in the mother-bud neck. Mol. Cell. Biol. 7, 3678-3687.

Hall, P. A., Russell, S. E. H. y Pringle, J. R. (2008). The Septins. Wiley-Blackwell. Oxford, UK.

Halme, A., Michelitch, M., Mitchell, E. L. y Chant, J. (1996). Bud10p directs axial cell polarization in budding yeast and resembles a transmembrane receptor. Curr. Biol. 6, 570-579.

Hartwell, L. H. (1971). Genetic control of the cell division cycle in yeast. IV. Genes controlling bud emergence and cytokinesis. Exp. Cell Res. 69, 265-276.

Harvey, K. y Tapon, N. (2007). The Salvador-Warts-Hippo pathway, an emerging tumour-suppressor network. Nat. Rev. Can. 7, 182-191.

Harvey, K. F. y Hariharan, I. K. (2012). The Hippo Pathway. Cold Spring Harb. Perspect. Biol. 4, a011288

Hazan, I., Sepulveda-Becerra, M. y Liu, H. (2002). Hyphal elongation is regulated independently of cell cycle in Candida albicans. Mol. Biol. Cell 13, 134-145.

Hellen, C. y Sarnow, P. (2001). Internal ribosome entry sites in eukaryotic mRNA molecules. Genes Dev. 15, 1593-1612.

Hergovich, A. (2011). MOB control: reviewing a conserved family of kinase regulators. Cell. Signal. 23, 1433-1440.

Hergovich, A. (2012). Mammalian Hippo signalling: a kinase network regulated by protein-protein interactions. Biochem. Soc. Trans. 40, 124-128.

Hergovich, A., Cornils, H. y Hemmings, B. A. (2008). Mammalian NDR protein kinases: from regulation to a role in centrosome duplication. Biochim. Biophys. Acta 1784, 3-15.

Hergovich, A., Stegert, M. R. y Schmitz, D. (2006). NDR kinases regulate essential cell processes from yeast to humans. Rev. Mol. Cell 7, 253-264.

Hernández-Rodríguez, Y. y Momany, M. (2012). Posttranslational modifications and assembly of septin heteropolymers and higher-order structures. Curr. Opin. Microbiol. 15, 660-668.

Hinnebusch, A. G. (1997). Translational regulation of yeast GCN4. J. Biol. Chem. 272, 21661-21664.

Hinnebusch, A. G. (2011). Molecular mechanism of scanning and start codon selection in eukaryotes. Microbiol. Mol. Biol. Rev. 74, 434-467. 
Hollenhorst, P. C., Pietz, G. y Fox, C. A. (2001). Mechanisms controlling differential promoter-occupancy by the yeast forkhead proteins Fkh1p and Fkh2p: implications for regulating the cell cycle and differentiation. Genes Dev. 15, 2445-2456.

Holmes, J. K. y Solomon, M. J. (1996). A predictive scale for evaluating cyclin-dependent kinase substrates. A comparison of p34cdc2 and p33cdk2. J. Biol. Chem. 271, 25240-25246.

Holt, L. J., Tuch, B. B., Villén, J., Johnson, A. D., Gygi, S. P. y Morgan, D. O. (2009). Global analysis of Cdk1 substrate phosphorylation sites provides insights into evolution. Science 325, 1682-1686.

Hoppe, T., Matuschewski, K., Rape, M., Schlenker, S., Ulrich, H. D. y Jentsch, S. (2000). Activation of a membrane-bound transcription factor by regulated ubiquitin/proteasome-dependent processing. Cell 102, 577-586.

Hornby, J. M., Jensen, E. C., Lisec, A. D., Tasto, J. J., Jahnke, B., Shoemaker, R., Dussault, P. y Nickerson, K. W. (2001). Quorum sensing in the dimorphic fungus Candida albicans is mediated by farnesol. Appl. Environ. Microbiol. 67, 2982-2992.

Iwase, M., Luo, J., Nagaraj, S., Longtine, M., Kim, H. B., Haarer, B. K., Caruso, C., Tong, Z., Pringle, J. R. y Bi, E. (2006). Role of a Cdc42p effector pathway in recruitment of the yeast septins to the presumptive bud site. Mol. Biol. Cell 17, 1110-1125.

Jansen, J. M., Barry, M. F., Yoo, C. K. y Weiss, E. L. (2006). Phosphoregulation of Cbk1 is critical for RAM network control of transcription and morphogenesis. J. Cell Biol. 175, 755-766.

Jensen, T. H., Neville, M., Rain, J. C., McCarthy, T., Legrain, P. y Rosbash, M. (2000). Identification of novel Saccharomyces cerevisiae proteins with nuclear export activity: cell cycle-regulated transcription factor Ace $2 p$ shows cell cycleindependent nucleocytoplasmic shuttling. Mol. Cell. Biol. 20, 8047-8058.

John, C. M., Hite, R. K., Weirich, C. S., Fitzgerald, D. J., Jawhari, H., Faty, M., Schläpfer, D., Kroschewski, R., Winkler, F. K., Walz, T. y Barral, Y. (2007). The Caenorhabditis elegans septin complex is nonpolar. EMBO J. 26, 3296-3307.

Johnson, E. S. y Blobel, G. (1999). Cell cycle-regulated attachment of the ubiquitin-related protein SUMO to the yeast septins. J. Cell Biol. 147, 981-994.

Jones, L. A. y Sudbery, P. E. (2010). Spitzenkorper, exocyst, and polarisome components in Candida albicans hyphae show different patterns of localization and have distinct dynamic properties. Eukaryot. Cell 9, 1455-1465.

Jorgensen, P., Nelson, B., Robinson, M. D., Chen, Y., Andrews, B., Tyers, M. y Boone, C. (2002). High-resolution genetic mapping with ordered arrays of Saccharomyces cerevisiae deletion mutants. Genetics 162, 1091-1099.

Kadosh, D. y Johnson, A. D. (2001). Rfg1, a protein related to the Saccharomyces cerevisiae hypoxic regulator Rox1, controls filamentous growth and virulence in Candida albicans. Mol. Cell. Biol. 21, 2496-2505.

Kadosh, D. y Johnson, A. D. (2005). Induction of the Candida albicans filamentous growth program by relief of transcriptional repression: a genome-wide analysis. Mol. Biol. Cell 16, 2903-2912.

Kadota, J., Yamamoto, T., Yoshiuchi, S., Bi, E. y Tanaka, K. (2004). Septin ring assembly requires concerted action of polarisome components, a PAK kinase Cla4p, and the actin cytoskeleton in Saccharomyces cerevisiae. Mol. Biol. Cell 15, 5329-5345.

Kamran, M., Calcagno, A.-M., Findon, H., Bignell, E., Jones, M. D., Warn, P., Hopkins, P., Denning, D. W., Butler, G., Rogers, T. y Haynes, K. (2004). Inactivation of transcription factor gene ACE2 in the fungal pathogen Candida glabrata results in hypervirulence. Eukaryot. Cell 3, 546-552.

Kaneko, A., Umeyama, T., Hanaoka, N., Monk, B. C., Uehara, Y. y Niimi, M. (2004). Tandem affinity purification of the Candida albicans septin protein complex. Yeast 21, 1025-1033.

Keaton, M. A. y Lew, D. J. (2006). Eavesdropping on the cytoskeleton: progress and controversy in the yeast morphogenesis checkpoint. Curr. Opin. Microbiol. 9, 540-546.

Kelen, K., Beyaert, R. y Inzé, D. (2009). Translational control of eukaryotic gene expression. Crit. Rev. Biochem. Mol. Biol. 44, 143-168.

Kelly, M. T., MacCallum, D. M., Clancy, S. D., Odds, F. C., Brown, A. J. P. y Butler, G. (2004). The Candida albicans CaACE2 gene affects morphogenesis, adherence and virulence. Mol. Microbiol. 53, 969-983.

Klis, F. M., de Groot, P. y Hellingwerf, K. (2001). Molecular organization of the cell wall of Candida albicans. Med. Mycol. 39 Suppl 1, 1-8.

Koranda, M., Schleiffer, A., Endler, L. y Ammerer, G. (2000). Forkhead-like transcription factors recruit Ndd1 to the chromatin of G2/M-specific promoters. Nature 406, 94-98.

Kozak, M. (1989). Circumstances and mechanisms of inhibition of translation by secondary structure in eucaryotic mRNAs. Mol. Cell. Biol. 9, 5134-5142.

Kozak, M. (2002). Pushing the limits of the scanning mechanism for initiation of translation. Gene. 299, 1-34.

Kozak, M. (2005). Regulation of translation via mRNA structure in prokaryotes and eukaryotes. Gene. 361, 13-37. 
Kron, S. J. y Gow, N. A. (1995). Budding yeast morphogenesis: signalling, cytoskeleton and cell cycle. Curr. Opin. Cell Biol. 7, $845-855$.

Kron, S. J., Styles, C. A. y Fink, G. R. (1994). Symmetric cell division in pseudohyphae of the yeast Saccharomyces cerevisiae. Mol. Biol. Cell 5, 1003-1022.

Kuranda, M. J. y Robbins, P. W. (1987). Cloning and heterologous expression of glycosidase genes from Saccharomyces cerevisiae. Proc. Natl. Acad. Sci. U.S.A. 84, 2585-2589.

Kurischko, C., Kuravi, V. K., Wannissorn, N., Nazarov, P. A., Husain, M., Zhang, C., Shokat, K. M., McCaffery, J. M. y Luca, F. C. (2008). The yeast LATS/Ndr kinase Cbk1 regulates growth via Golgi-dependent glycosylation and secretion. Mol. Biol. Cell 19, 5559-5578.

Kusch, J., Meyer, A., Snyder, M. P. y Barral, Y. (2002). Microtubule capture by the cleavage apparatus is required for proper spindle positioning in yeast. Genes Dev. 16, 1627-1639.

Kushner, S. R. (1978). An improved method for transformation of Escherichia coli with ColE1 derived plasmids. En Genetic Engineering. H.S. Boyer y S. Nicosia n(eds.). Elsevier/North-Holland Publishing Co. Amsterdam. pp 17-24.

Kyriakis, J. M. y Avruch, J. (2012). Mammalian MAPK signal transduction pathways activated by stress and inflammation: a 10-year update. Physiol. Rev. 92, 689-737.

Lal, M. y Caplan, M. (2011). Regulated intramembrane proteolysis: signaling pathways and biological functions. Physiology 26, 34-44.

Leberer, E., Harcus, D., Broadbent, I. D., Clark, K. L., Dignard, D., Ziegelbauer, K., Schmidt, A., Gow, N. A., Brown, A. J. y Thomas, D. Y. (1996). Signal transduction through homologs of the Ste20p and Ste7p protein kinases can trigger hyphal formation in the pathogenic fungus Candida albicans. Proc. Natl. Acad. Sci. U.S.A. 93, 13217-13222.

Leberer, E., Harcus, D., Dignard, D., Johnson, L., Ushinsky, S., Thomas, D. Y. y Schröppel, K. (2001). Ras links cellular morphogenesis to virulence by regulation of the MAP kinase and CAMP signalling pathways in the pathogenic fungus Candida albicans. Mol. Microbiol. 42, 673-687.

Leissring, M. A., Farris, W. y Wu, X. (2004). Alternative translation initiation generates a novel isoform of insulin-degrading enzyme targeted to mitochondria. Biochem. J. 383, 439-446.

Lew, D. J. (2003). The morphogenesis checkpoint: how yeast cells watch their figures. Curr. Opin. Cell Biol. 15, 648-653.

Lew, D. J. y Reed, S. I. (1995). A cell cycle checkpoint monitors cell morphogenesis in budding yeast. J. Cell Biol. 129, 739-749.

Li, C.-R., Lee, R. T.-H., Wang, Y.-M., Zheng, X.-D. y Wang, Y. (2007). Candida albicans hyphal morphogenesis occurs in Sec3pindependent and Sec3p-dependent phases separated by septin ring formation. J. Cell. Sci. 120, 1898-1907.

Li, C.-R., Yong, J.-Y. A., Wang, Y.-M. y Wang, Y. (2012a). CDK regulates septin organization through cell-cycle-dependent phosphorylation of the Nim1-related kinase Gin4. J. Cell. Sci. 125, 2533-2543.

Li, L., Zhang, C. y Konopka, J. B. (2012b). A Candida albicans temperature-sensitive cdc12-6 mutant identifies roles for septins in selection of sites of germ tube formation and hyphal morphogenesis. Eukaryot. Cell 11, 1210-1218.

Lindsey, R. y Momany, M. (2006). Septin localization across kingdoms: three themes with variations. Curr. Opin. Microbiol. 9, 559-565.

Loeb, J. D., Sepulveda-Becerra, M., Hazan, I. y Liu, H. (1999). A G1 cyclin is necessary for maintenance of filamentous growth in Candida albicans. Mol. Cell. Biol. 19, 4019-4027.

Longtine, M. S. y Bi, E. (2003). Regulation of septin organization and function in yeast. Trends Cell Biol. 13, 403-409.

Longtine, M. S., Fares, H. y Pringle, J. R. (1998). Role of the yeast Gin4p protein kinase in septin assembly and the relationship between septin assembly and septin function. J. Cell Biol. 143, 719-736.

Longtine, M. S., Theesfeld, C. L., McMillan, J. N., Weaver, E., Pringle, J. R. y Lew, D. J. (2000). Septin-dependent assembly of a cell cycle-regulatory module in Saccharomyces cerevisiae. Mol. Cell. Biol. 20, 4049-4061.

Lorenz, M. C., Bender, J. A. y Fink, G. R. (2004). Transcriptional response of Candida albicans upon internalization by macrophages. Eukaryot. Cell 3, 1076-1087.

Lu, Y., Mahony, S., Benos, P. V., Rosenfeld, R., Simon, I., Breeden, L. L. y Bar-Joseph, Z. (2007). Combined analysis reveals a core set of cycling genes. Genome Biol. 8, R146.

Luedeke, C., Frei, S. B., Sbalzarini, I., Schwarz, H., Spang, A. y Barral, Y. (2005). Septin-dependent compartmentalization of the endoplasmic reticulum during yeast polarized growth. J. Cell Biol. 169, 897-908.

Maerz, S. y Seiler, S. (2010). Tales of RAM and MOR: NDR kinase signaling in fungal morphogenesis. Curr. Opin. Microbiol. 13, 663-671. 
Martin, R., Moran, G. P., Jacobsen, I. D., Heyken, A., Domey, J., Sullivan, D. J., Kurzai, O. y Hube, B. (2011). The Candida albicans-specific gene EED1 encodes a key regulator of hyphal extension. PLOS ONE 6, e18394.

Martin, S. W. y Konopka, J. B. (2004). SUMO modification of septin-interacting proteins in Candida albicans. J. Biol. Chem. 279, 40861-40867.

Mazanka, E. y Weiss, E. L. (2010). Sequential counteracting kinases restrict an asymmetric gene expression program to early G1. Mol. Biol. Cell 21, 2809-2820.

Mazanka, E., Alexander, J., Yeh, B. J. y Charoenpong, P. (2008). The NDR/LATS family kinase Cbk1 directly controls transcriptional asymmetry. PLoS Biol. 6, e203.

McBride, H. J., Yu, Y. y Stillman, D. J. (1999). Distinct regions of the Swi5 and Ace2 transcription factors are required for specific gene activation. J. Biol. Chem. 274, 21029-21036.

McCreath, K. J., Specht, C. A. y Robbins, P. W. (1995). Molecular cloning and characterization of chitinase genes from Candida albicans. Proc. Natl. Acad. Sci. U.S.A. 92, 2544-2548.

McCreath, K. J., Specht, C. A., Liu, Y. y Robbins, P. W. (1996). Molecular cloning of a third chitinase gene (CHT1) from Candida albicans. Yeast 12, 501-504.

Mcllhatton, M. A., Burrows, J. F., Donaghy, P. G., Chanduloy, S., Johnston, P. G. y Russell, S. E. (2001). Genomic organization, complex splicing pattern and expression of a human septin gene on chromosome 17q25.3. Oncogene 20, 5930-5939.

McMurray, M. A. y Thorner, J. (2009). Septins: molecular partitioning and the generation of cellular asymmetry. Cell Div 4, 18.

McNemar, M. D. y Fonzi, W. A. (2002). Conserved serine/threonine kinase encoded by CBK1 regulates expression of several hypha-associated transcripts and genes encoding cell wall proteins in Candida albicans. J. Bacteriol. 184, 2058-2061.

Mendoza, M., Hyman, A. A. y Glotzer, M. (2002). GTP binding induces filament assembly of a recombinant septin. Curr. Biol. 12, 1858-1863.

Merlini, L. y Piatti, S. (2011). The mother-bud neck as a signaling platform for the coordination between spindle position and cytokinesis in budding yeast. Biol. Chem. 392, 805-812.

Meseroll, R. A., Occhipinti, P. y Gladfelter, A. S. (2012). Septin phosphorylation and coiled-coil domains function in cell and septin ring morphology in the filamentous fungus Ashbya gossypii. Eukaryot. Cell. doi:10.1128/EC.00251-12

Mino, A., Tanaka, K., Kamei, T., Umikawa, M., Fujiwara, T. y Takai, Y. (1998). Shs1p: a novel member of septin that interacts with Spa2p, involved in polarized growth in Saccharomyces cerevisiae. Biochem. Biophys. Res. Commun. 251, 732-736.

Mitchell, L., Lau, A., Lambert, J.-P., Zhou, H., Fong, Y., Couture, J.-F., Figeys, D. y Baetz, K. (2011). Regulation of septin dynamics by the Saccharomyces cerevisiae lysine acetyltransferase NuA4. PLoS ONE 6, e25336.

Mitchison, T. J. y Field, C. M. (2002). Cytoskeleton: what does GTP do for septins? Curr. Biol. 12, R788-90.

Mortensen, E. M., McDonald, H., Yates, J. y Kellogg, D. R. (2002). Cell cycle-dependent assembly of a Gin4-septin complex. Mol. Biol. Cell 13, 2091-2105.

Mostowy, S. y Cossart, P. (2012). Septins: the fourth component of the cytoskeleton. Nat. Rev. Mol. Cell Biol. 13, $183-194$.

Mulhern, S. M., Logue, M. E. y Butler, G. (2006). Candida albicans transcription factor Ace2 regulates metabolism and is required for filamentation in hypoxic conditions. Eukaryot. Cell 5, 2001-2013.

Murakami, T., Kondo, S., Ogata, M., Kanemoto, S., Saito, A., Wanaka, A. y Imaizumi, K. (2006). Cleavage of the membranebound transcription factor OASIS in response to endoplasmic reticulum stress. J. Neurochem. 96, 1090-1100.

Nantel, A., Dignard, D., Bachewich, C., Harcus, D., Marcil, A., Bouin, A.-P., Sensen, C. W., Hogues, H., van Het Hoog, M., Gordon, P. y Whiteway, M. (2002). Transcription profiling of Candida albicans cells undergoing the yeast-to-hyphal transition. Mol. Biol. Cell 13, 3452-3465.

Nelson, B., Kurischko, C., Horecka, J., Mody, M., Nair, P., Pratt, L., Zougman, A., McBroom, L. D. B., Hughes, T. R., Boone, C. y Luca, F. (2003). RAM: a conserved signaling network that regulates Ace2p transcriptional activity and polarized morphogenesis. Mol. Biol. Cell 14, 3782-3803.

Nobile, C. J. y Mitchell, A. P. (2005). Regulation of cell-surface genes and biofilm formation by the C. albicans transcription factor Bcr1p. Curr. Biol. 15, 1150-1155.

Nobile, C. J. y Mitchell, A. P. (2006). Genetics and genomics of Candida albicans biofilm formation. Cell. Microbiol. 8, 13821391.

Nobile, C. J., Nett, J. E., Andes, D. R. y Mitchell, A. P. (2006). Function of Candida albicans adhesin Hwp1 in biofilm formation. Eukaryot. Cell 5, 1604-1610.

Nobile, C. J., Nett, J. E., Hernday, A. D., Homann, O. R., Deneault, J.-S., Nantel, A., Andes, D. R., Johnson, A. D. y Mitchell, A. 
P. (2009). Biofilm matrix regulation by Candida albicans Zap1. PLoS Biol. 7, e1000133.

Noble, S. M., French, S., Kohn, L. A., Chen, V. y Johnson, A. D. (2010). Systematic screens of a Candida albicans homozygous deletion library decouple morphogenetic switching and pathogenicity. Nat. Genet. 42, 590-598.

O'Conallain, C., Doolin, M. T., Taggart, C., Thornton, F. y Butler, G. (1999). Regulated nuclear localisation of the yeast transcription factor Ace2p controls expression of chitinase (CTS1) in Saccharomyces cerevisiae. Mol. Gen. Genet. 262, 275-282.

O'Conallain, C., Doolin, T. y Butler, G. (1998). Inappropriate expression of the yeast transcription factor Ace2p affects cell growth. Biochem. Soc. Trans. 26, S78.

Oberholzer, U., Marcil, A., Leberer, E., Thomas, D. Y. y Whiteway, M. (2002). Myosin I is required for hypha formation in Candida albicans. Eukaryot. Cell 1, 213-228.

Odds, F. C. (1988). Candida and candidosis. University Park Press

Ofir, A. y Kornitzer, D. (2010). Candida albicans cyclin Clb4 carries S-phase cyclin activity. Eukaryot. Cell 9, 1311-1319.

Oh, Y. y Bi, E. (2011). Septin structure and function in yeast and beyond. Trends Cell Biol. 21, 141-148.

Pan, D. (2010). The hippo signaling pathway in development and cancer. Dev. Cell. 19, 491-505.

Pan, F., Malmberg, R. L. y Momany, M. (2007). Analysis of septins across kingdoms reveals orthology and new motifs. BMC Evol. Biol. 7, 103.

Panozzo, C., Bourens, M., Nowacka, A. y Herbert, C. J. (2010). Mutations in the C-terminus of the conserved NDR kinase, Cbk1p of Saccharomyces cerevisiae, make the protein independent of upstream activators. Mol. Genet. Genomics 283, 111-122.

PerIman, D., Raney, P. y Halvorson, H. O. (1984). Cytoplasmic and secreted Saccharomyces cerevisiae invertase mRNAs encoded by one gene can be differentially or coordinately regulated. Mol. Cell Biol. 4, 1682-1688.

Petit, C. S., Mehta, S., Roberts, R. H. y Gould, K. L. (2005). Ace2p contributes to fission yeast septin ring assembly by regulating mid2+ expression. J. Cell. Sci. 118, 5731-5742.

Pfaller, M. A. y Diekema, D. J. (2007). Epidemiology of invasive candidiasis: a persistent public health problem. Clin. Microbiol. Rev. 20, 133-163.

Phan, Q. T., Belanger, P. H. y Filler, S. G. (2000). Role of hyphal formation in interactions of Candida albicans with endothelial cells. Infect. Immun. 68, 3485-3490.

Phillips, S. N., Muzaffar, N., Codlin, S., Korey, C. A., Taschner, P. E. M., de Voer, G., Mole, S. E. y Pearce, D. A. (2006). Characterizing pathogenic processes in Batten disease: use of small eukaryotic model systems. Biochim. Biophys. Acta 1762, 906-919.

Pruyne, D. y Bretscher, A. (2000a). Polarization of cell growth in yeast. J. Cell. Sci. 113, 571-585.

Pruyne, D. y Bretscher, A. (2000b). Polarization of cell growth in yeast. I. Establishment and maintenance of polarity states. J. Cell. Sci. 113, 365-375.

Racki, W. J., Bécam, A. M., Nasr, F. y Herbert, C. J. (2000). Cbk1p, a protein similar to the human myotonic dystrophy kinase, is essential for normal morphogenesis in Saccharomyces cerevisiae. EMBO J. 19, 4524-4532.

Ramos, A. and Camargo, F. D. (2012). The Hippo signaling pathway and stem cell biology. Trends Cell Biol. 7, 339-346.

Reijnst, P., Jorde, S. y Wendland, J. (2010). Candida albicans SH3-domain proteins involved in hyphal growth, cytokinesis, and vacuolar morphology. Curr. Genet. 56, 309-319.

Reuss, O., Vik, A., Kolter, R. y Morschhäuser, J. (2004). The SAT1 flipper, an optimized tool for gene disruption in Candida albicans. Gene 341, 119-127.

Roemer, T., Madden, K., Chang, J. y Snyder, M. (1996). Selection of axial growth sites in yeast requires Axl2p, a novel plasma membrane glycoprotein. Genes Dev. 10, 777-793.

Rothstein, R. (1991). Targeting, disruption, replacement, and allele rescue: integrative DNA transformation in yeast. Meth. Enzymol. 194, 281-301.

Saarikangas, J. y Barral, Y. (2011). The emerging functions of septins in metazoans. EMBO Rep. 12, 1118-1126.

Sambrook, J. y D.W. Russell. (2001). Molecular Cloning: A Laboratory Manual. Cold Spring Harbour. New York: Cold Spring Harbour Laboratory Press.

Sanders, S. L. y Herskowitz, I. (1996). The BUD4 protein of yeast, required for axial budding, is localized to the mother/BUD neck in a cell cycle-dependent manner. J. Cell Biol. 134, 413-427.

Santos, M. A., Cheesman, C., Costa, V., Moradas-Ferreira, P. y Tuite, M. F. (1999). Selective advantages created by codon 
ambiguity allowed for the evolution of an alternative genetic code in Candida spp. Mol. Microbiol. 31, 937-947.

Saputo, S., Chabrier-Rosello, Y., Luca, F., Kumar, A. y Krysan, D. (2012). The RAM network in pathogenic fungi. Eukaryot. Cell. 11, 708-717.

Sarbassov, D. D., Guertin, D. A., Ali, S. M. y Sabatini, D. M. (2005). Phosphorylation and regulation of Akt/PKB by the rictormTOR complex. Science 307, 1098-1101.

Sbia, M., Parnell, E. J., Yu, Y., Olsen, A. E., Kretschmann, K. L., Voth, W. P. y Stillman, D. J. (2008). Regulation of the yeast Ace2 transcription factor during the cell cycle. J. Biol. Chem. 283, 11135-11145.

Schaub, Y., Dünkler, A. y Walther, A. (2006). New pFA-cassettes for PCR-based gene manipulation in Candida albicans. J. Basic Microbiol. 46, 416-429.

Seo, P. J., Kim, S. G. y Park, C. M. (2008). Membrane-bound transcription factors in plants. Trends Plant Sci. 10, 550-556.

Shapiro, R. S., Uppuluri, P., Zaas, A. K., Collins, C., Senn, H., Perfect, J. R., Heitman, J. y Cowen, L. E. (2009). Hsp90 orchestrates temperature-dependent Candida albicans morphogenesis via Ras1-PKA signaling. Curr. Biol. 19, 621-629.

Shareck, J. y Belhumeur, P. (2011). Modulation of morphogenesis in Candida albicans by various small molecules. Eukaryot. Cell 10, 1004-1012.

Shcheprova, Z., Baldi, S., Frei, S. B., Gonnet, G. y Barral, Y. (2008). A mechanism for asymmetric segregation of age during yeast budding. Nature 454, 728-734.

Sherlock, G., Bahman, A. M., Mahal, A., Shieh, J. C., Ferreira, M. y Rosamond, J. (1994). Molecular cloning and analysis of CDC28 and cyclin homologues from the human fungal pathogen Candida albicans. Mol. Gen. Genet. 245, 716-723.

Shulewitz, M. J., Inouye, C. J. y Thorner, J. (1999). HsI7 localizes to a septin ring and serves as an adapter in a regulatory pathway that relieves tyrosine phosphorylation of $\mathrm{Cdc} 28$ protein kinase in Saccharomyces cerevisiae. Mol. Cell. Biol. 19, 7123-7137.

Sinha, I., Wang, Y.-M., Philp, R., Li, C.-R., Yap, W. H. y Wang, Y. (2007). Cyclin-dependent kinases control septin phosphorylation in Candida albicans hyphal development. Dev. Cell 13, 421-432.

Sirajuddin, M., Farkasovsky, M., Hauer, F., Kühlmann, D., Macara, I. G., Weyand, M., Stark, H. y Wittinghofer, A. (2007). Structural insight into filament formation by mammalian septins. Nature 449, 311-315.

Sirajuddin, M., Farkasovsky, M., Zent, E. y Wittinghofer, A. (2009). GTP-induced conformational changes in septins and implications for function. Proc. Natl. Acad. Sci. U.S.A. 106, 16592-16597.

Slabaugh, E. y Brandizzi, F. (2011). Membrane-tethered transcription factors provide a connection between stress response and developmental pathways. Plant Signal Behav 6, 1210-1211.

Smolka, M. B., Chen, S.-H., Maddox, P. S., Enserink, J. M., Albuquerque, C. P., Wei, X. X., Desai, A., Kolodner, R. D. y Zhou, H. (2006). An FHA domain-mediated protein interaction network of Rad53 reveals its role in polarized cell growth. J. Cell Biol. 175, 743-753.

Song, Y., Cheon, S. A., Lee, K. E., Lee, S.-Y., Lee, B.-K., Oh, D.-B., Kang, H. A. y Kim, J.-Y. (2008). Role of the RAM network in cell polarity and hyphal morphogenesis in Candida albicans. Mol. Biol. Cell 19, 5456-5477.

Spellman, P. T., Sherlock, G., Zhang, M. Q., Iyer, V. R., Anders, K., Eisen, M. B., Brown, P. O., Botstein, D. y Futcher, B. (1998). Comprehensive identification of cell cycle-regulated genes of the yeast Saccharomyces cerevisiae by microarray hybridization. Mol. Biol. Cell 9, 3273-3297.

Spiliotis, E. T. (2010). Regulation of microtubule organization and functions by septin GTPases. Cytoskeleton 67, 339-345.

Spiliotis, E. T. y Gladfelter, A. S. (2012). Spatial guidance of cell asymmetry: septin GTPases show the way. Traffic 13, 195-203.

Spiliotis, E. T. y Nelson, W. J. (2006). Here come the septins: novel polymers that coordinate intracellular functions and organization. J. Cell. Sci. 119, 4-10.

Staley, B. K. y Irvine, K. D. (2012). Hippo signaling in Drosophila: recent advances and insights. Dev. Dyn. 241, 3-15.

Steinberg, G. (2007). Hyphal growth: a tale of motors, lipids, and the Spitzenkörper. Eukaryot. Cell 6, 351-360.

Stoldt, V. R., Sonneborn, A., Leuker, C. E. y Ernst, J. F. (1997). Efg1p, an essential regulator of morphogenesis of the human pathogen Candida albicans, is a member of a conserved class of bHLH proteins regulating morphogenetic processes in fungi. EMBO J. 16, 1982-1991.

Sudbery, P. (2007). Morphogenesis of a human fungal pathogen requires septin phosphorylation. Dev. Cell 13, 315-316.

Sudbery, P. E. (2001). The germ tubes of Candida albicans hyphae and pseudohyphae show different patterns of septin ring localization. Mol. Microbiol. 41, 19-31.

Sudbery, P. E. (2011). Growth of Candida albicans hyphae. Nat. Rev. Microbiol. 9, 737-748. 
Sudbery, P., Gow, N. y Berman, J. (2004). The distinct morphogenic states of Candida albicans. Trends Microbiol. 12, $317-324$.

Sullivan, D. S., Biggins, S. y Rose, M. D. (1998). The yeast centrin, Cdc31p, and the interacting protein kinase, Kic1p, are required for cell integrity. J. Cell Biol. 143, 751-765.

Takahashi, Y., Iwase, M., Konishi, M., Tanaka, M., Toh-e, A. y Kikuchi, Y. (1999). Smt3, a SUMO-1 homolog, is conjugated to $\mathrm{Cdc3}$, a component of septin rings at the mother-bud neck in budding yeast. Biochem. Biophys. Res. Commun. 259, 582-587.

Takizawa, P. A., DeRisi, J. L., Wilhelm, J. E. y Vale, R. D. (2000). Plasma membrane compartmentalization in yeast by messenger RNA transport and a septin diffusion barrier. Science 290, 341-344.

Tanaka-Takiguchi, Y., Kinoshita, M. y Takiguchi, K. (2009). Septin-mediated uniform bracing of phospholipid membranes. Curr. Biol. 19, 140-145.

Tang, C. S. L. y Reed, S. I. (2002). Phosphorylation of the septin Cdc3 in G1 by the Cdc28 kinase is essential for efficient septin ring disassembly. Cell Cycle 1, 42-49.

Tasto, J. J., Morrell, J. L. y Gould, K. L. (2003). An anillin homologue, Mid2p, acts during fission yeast cytokinesis to organize the septin ring and promote cell separation. J. Cell Biol. 160, 1093-1103.

Tortorano, A. M., Kibbler, C., Peman, J., Bernhardt, H., Klingspor, L. y Grillot, R. (2006). Candidaemia in Europe: epidemiology and resistance. Int. J. Antimicrob. Agents 27, 359-366.

Touriol, C., Bornes, S., Bonnal, S., Audigier, S., Prats, H., Prats, A.-C. y Vagner, S. (2003). Generation of protein isoform diversity by alternative initiation of translation at non-AUG codons. Biol. Cell 95, 169-178.

Tsang, W. K., Cao, B. Y. y Wang, J. (1997). Sequence analysis of Candida albicans phosphoribosyl-aminoimidazole carboxylase (ADE2) gene. Yeast 13, 673-676.

Urban, S. (2009). Making the cut: central roles of intramembrane proteolysis in pathogenic microorganisms. Nat. Rev. Microbiol. 7, 411-423.

Vannini, A. y Cramer, P. (2012). Conservation between the RNA polymerase I, II, and III transcription initiation machineries. Mol. Cell 45, 439-446.

Varelas, X., Samavarchi-Tehrani, P. y Narimatsu, M. (2010). The Crumbs complex couples cell density sensing to Hippodependent control of the TGF- $\beta-$ SMAD pathway. Dev. Cell. 14, 831-844.

Vázquez de Aldana, C.R. y Correa-Bordes, J. (2012). Integrating Cdk signaling in Candida albicans environmental sensing networks. Morphogenesis and Pathogenicity in Fungy. 22, 81-96.

Versele, M. y Thorner, J. (2004). Septin collar formation in budding yeast requires GTP binding and direct phosphorylation by the PAK, Cla4. J. Cell Biol. 164, 701-715.

Versele, M. y Thorner, J. (2005). Some assembly required: yeast septins provide the instruction manual. Trends Cell Biol. 15, 414-424.

Virag, A. y Harris, S. D. (2006). The Spitzenkörper: a molecular perspective. Mycol. Res. 110, 4-13.

Vrabioiu, A. M. y Mitchison, T. J. (2006). Structural insights into yeast septin organization from polarized fluorescence microscopy. Nature 443, 466-469.

Vrabioiu, A. M. y Mitchison, T. J. (2007). Symmetry of septin hourglass and ring structures. J. Mol. Biol. 372, 37-49.

Walther, A. y Wendland, J. (2004). Polarized hyphal growth in Candida albicans requires the Wiskott-Aldrich Syndrome protein homolog Wal1p. Eukaryot. Cell 3, 471-482.

Walther, A. y Wendland, J. (2003). An improved transformation protocol for the human fungal pathogen Candida albicans. Curr. Genet. 42, 339-343.

Wang, A., Raniga, P. P., Lane, S., Lu, Y. y Liu, H. (2009). Hyphal chain formation in Candida albicans: Cdc28-Hgc1 phosphorylation of Efg1 represses cell separation genes. Mol. Cell. Biol. 29, 4406-4416.

Wang, Y. (2009). CDKs and the yeast-hyphal decision. Curr. Opin. Microbiol. 12, 644-649.

Warenda, A. J. y Konopka, J. B. (2002). Septin function in Candida albicans morphogenesis. Mol. Biol. Cell 13, $2732-2746$.

Warenda, A. J., Kauffman, S., Sherrill, T. P., Becker, J. M. y Konopka, J. B. (2003). Candida albicans septin mutants are defective for invasive growth and virulence. Infect. Immun. 71, 4045-4051.

Weirich, C. S., Erzberger, J. P. y Barral, Y. (2008). The septin family of GTPases: architecture and dynamics. Nat. Rev. Mol. Cell Biol. 9, 478-489.

Weiss, E. L., Kurischko, C., Zhang, C., Shokat, K., Drubin, D. G. y Luca, F. C. (2002). The Saccharomyces cerevisiae Mob2pCbk1p kinase complex promotes polarized growth and acts with the mitotic exit network to facilitate daughter cell-specific 
localization of Ace2p transcription factor. J. Cell Biol. 158, 885-900.

Weiss, E. L. (2012). Mitotic exit and separation of mother and daughter cells. Genetics 192, 1165-1202.

Wightman, R., Bates, S., Amornrrattanapan, P. y Sudbery, P. (2004). In Candida albicans, the Nim1 kinases Gin4 and Hsl1 negatively regulate pseudohypha formation and Gin4 also controls septin organization. J. Cell Biol. 164, 581-591.

Wilson, R. B., Davis, D. y Mitchell, A. P. (1999). Rapid hypothesis testing with Candida albicans through gene disruption with short homology regions. J. Bacteriol. 181, 1868-1874.

Xu, X.-L., Lee, R. T.-H., Fang, H.-M., Wang, Y.-M., Li, R., Zou, H., Zhu, Y. y Wang, Y. (2008). Bacterial peptidoglycan triggers Candida albicans hyphal growth by directly activating the adenylyl cyclase Cyr1p. Cell Host Microbe 4, 28-39.

Yang, J., Cron, P., Good, V. M., Thompson, V., Hemmings, B. A. y Barford, D. (2002). Crystal structure of an activated Akt/ protein kinase B ternary complex with GSK3-peptide and AMP-PNP. Nat. Struct. Biol. 9, 940-944.

Zacchi, L. F., Schulz, W. L. y Davis, D. A. (2010). HOS2 and HDA1 encode histone deacetylases with opposing roles in Candida albicans morphogenesis. PLOS ONE 5, e12171.

Zeng, G., Wang, Y. M. y Wang, Y. (2012). Cdc28-Cln3 phosphorylation of Sla1 regulates actin patch dynamics in different modes of fungal growth. Mol. Biol. Cell. 23, 3485-34-97.

Zhang, J., Kong, C., Xie, H., McPherson, P. S., Grinstein, S. y Trimble, W. S. (1999). Phosphatidylinositol polyphosphate binding to the mammalian septin H5 is modulated by GTP. Curr. Biol. 9, 1458-1467.

Zhao, B., Li, L., Lu, Q., Wang, L. H., Liu, C.-Y., Lei, Q. y Guan, K.-L. (2011). Angiomotin is a novel Hippo pathway component that inhibits YAP oncoprotein. Genes Dev. 25, 51-63.

Zheng, X. D., Lee, R., Wang, Y. M., Lin, Q. S. y Wang, Y. (2007). Phosphorylation of Rga2, a Cdc42 GAP, by CDK/Hgc1 is crucial for Candida albicans hyphal growth. EMBO J. 26, 3760-3769.

Zheng, X., Wang, Y. and Wang, Y. (2004). Hgc1, a novel hypha-specific G1 cyclin-related protein regulates Candida albicans hyphal morphogenesis. EMBO J. 23, 1845-1856.

Zou, H., Fang, H.-M., Zhu, Y. y Wang, Y. (2010). Candida albicans Cyr1, Cap1 and G-actin form a sensor/effector apparatus for activating CAMP synthesis in hyphal growth. Mol. Microbiol. 75, 579-591. 